\title{
DISCLAIMER
}

This report was prepared as an account of work sponsored by an agency of the United States Government. Neither the United States Government nor any agency thereof, nor any of their employees, makes any warranty, express or implied, or assurnes any legal liability or responsibility for the accuracy, completeness, or usefulness of any information, apparatus, product, or process disclosed, or represents that its use would not infringe privately owned rights. Reference herein to any specific commercial product, prc iess, or service by trade name, trademark, manufacturer, or otherwise does not necessarily constitute or imply its endorsement, recommendation, or favoring by the United States Government or any agency thereof. The views and opinions of authors expressed herein do not necessarily state or reflect those of the United States Government or any agency thereof.

This report has been reproduced directly from the best available copy.

Available to DOE and DOE contractors from the Office of Scientific and Technical Information, P.O. Box 62, Oak Ridge, TN 37831; prices available from (615)576-8401, FTS 626-8401.

Available to the public from the National Technical Information Service, U.S. Department of Commerce, 5285 Port Royal Rd., Springfield, VA 22161. 


\section{ARC/EPRI Consortium}

Coal Processing Development Program

\section{Development of Clean Coal and Clean Soil Technologies Using Advanced Agglomeration Technologies}

\section{Volume 2 - Upgrading of Bituminous Coals: The Aglofloat Process}

DE-FG22-87PC79865

Prepared by

Alberta Research Council

Coal and Hydrocarbon Processing Department

Devon, Alberta, Canada TOC 1 E0

Principal Investigators

B. Ignasiak

W. Pawlak

K. Szymocha

J. Marr

April 1990 


\section{Notice}

The material in this Report is intended for general information only. Any use of this material in relation to any specific application should be based on independent examination and verification of its unrestricted applicability for such use and/or a determination of its suitability for the application. No license under any Aberta Research Council patents or other proprietary interest is implied by the publication of this Report. Those making use of or relying upon the material assume all risks and liability aris: ing from such use or reliance. 
These reports form the final output of the Phase I Coal Processing Development Consortium that jointly pursued the funding and development of advanced coaVoil agglomeration technologies from June 1987 to December 1989. For many of the participants, it was a challenging new experience and one that led to some important lessons and technical oppontunities. Technology resulting from the treatment of tarry wastes is being seriously pursued as a commercial venture in Canada and the USA. The pyrite rejection technology is being scaled up in the USA, and the low rank coalheavy oil technologies are being investigated in Canada. The financial and technical support of the consortium members in Phase $I$ is acknowledged and recognized. Without their support, the program would not have been as successful as it was.

Phase II of the Coal Processing Development Program will be continued until December 1990 to provide more in-depth engineering data and scale up support for the key program elements. Results of Phase II and the overall conclusions will be reported in 1991. The continuing support of the Phase II participants is also acknowledged, and they are thanked for their on-going interest and contributions.

The Alberta Research Council thanks the Electric Power Research Institute, their program staff and representatives on the management and technical committees, for their support and guidance in our mutual work. Our special thanks go to Howard Lebowitz, Linda Atherton, Conrad Kulik, Bill Rovesti, Bill Weber ano Norm Stewart.

Finally, we wish to thank the technical and support teams of the Alberta Research Council who have made the projects as successful as they are and who have worked under ever increasing demanding scopes of work as the program developed and improved.

Dr. Arvid H. Hardin, Department Head Coal and Hydrocarbon Processing Alberta Research Council Devon, Aberta July 1990 


\section{Abstract}

This report documents work completed by the Alberta Research Council for the ARC/EPRI Consortium, under the program entitled "Coal Processing Development Program: Development of Clean Coal and Clean Soil Technologies Using Advanced Agglomeration Techniques". The report is divided into three volumes:

\section{Volume 1. Upgrading of Low Rank Coals: The Agflotherm Process}

Test data, procecures, equipment, etc., are described for $\infty$-upgrading of subbituminous coals and heavy oil. The test results showed upgraded coals to have heating value above 11,000 BTU/b, and syncrude (upgraded he3vy oil) to have 21\# API gravity or better. The coal products were acceptable for combustion and had handling properties superior to those of subbituminous coals. The syncrude was suitable for pipelining and refining. The technoeconomic feasibility study of the Agflotherm process suggests that upgraded coal could be produced at \$Cdn 37.90 per metric tonne at 15 percent DCF ROR (fob plant, after tax).

\section{Volume 2. Upgrading of Bltuminous Coals: The} Aglofloat Process

Experimental procecures and data, bench and pilot scale equipments, etc., for beneficiating bituminous coals are described. The test results showed the beneficiated coal to have heating value of 13,000 BTU/b or better, ash content of less than 10 percent and pyritic sulphur removal of up to 90 percent. The completed techno-economic feasibility study of the Aglofloat process suggests that beneficiated coal could be produced at \$U.S. 52.85 per short ton, at ROM coal prices of \$U.S. 27n. For coal wash plant wastes, the product price would be \$U.S. 25.26 per ton.

\section{Volume 3. Soil Clean-up and Hydrocarbon Waste Treatment Process}

Batch and pilot plant tests are described for soil contaminated by tar refuse from manufactured gas plant sites. The test results show the treated soil to be suitable for disposal in landfills and the by-product agglomerates containing tar and hydrocarbon contaminants to be sultable for combustion in industrial boilers. The fechno-economic feasibility study of a mobile plant for the Clean Soll process shows the cost of cleaning to range from SCdn 31.39 to SCdn 46.97 per tonne of oily wastes, and to be about sCon 45 per tome of tar refuse contaminated soil. 


\section{Acknowledgements}

The multidisciplinary nature of the program undertaken required a group of experts from several fields of coal development technology. As a result, the achievements described in this report are, in part, due to the contributions of several subcontracted companies and individuals. Specifically, we would like to acknowledge the contributions of Sam Wong of ARC Tochnical and Economic Evaluation Group. for the economic analysis and costing of the conceptual Aglofloat plant; Lobbe Technologies Lid.,

Regina, Saskatchewan, for the development of the Aglofloat plant design and for the preparation of this Final Report; and the Alberta Research Council Corporate Communications department for the production of this Final Report. 


\section{Introduction}

In 1987, the Alberta Research Council and EPRI formed a research consortium to develop new clean coal and clean soil techrologies based on ARC's advanced spherical agglomeration research. The Consortium included 19 companies, government agencies and non-profit research organizations (see Appendix 1). The Consortium identified three technology development areas as being of immediate in terest to its members:

1. Co-upgrading of low-rank coals and heavy oils.

2. Beneficiation of high sulphur bitumincus coals.

3. Cleaning of tar refuse and hydrocarbon contaminated soils.

The Consortium authorized ARC to undertake research and development programs addressing technology needs in each of the identified areas. The programs were to include laboratory research and testing, fundamental engineering studies, development and operation of integrated agglomeration pilot plant facilities, and conceptual design and economic studies for the processes developed. The following is a summary of the projects undertaken and work completed to December 1989. It should be emphasized that since December, 1989, major progrcas has been made in further development of the three technologies and particularty in contaminated soil clean-up.

\section{Co-Upgrading of Low Rank coals and Heavy oils}

The objective of the project was to apply advanced agglomeration technology for co-upgrading of lowrank coals and heavy oil, namoly:

- to increase the heating value of low-rank coals above $25.5 \mathrm{GM}$ ( 14,000 . Btu/b) by dewatering and deashing (upgrading) low-rank coals to capacity moisture and ash content of less than 10 percent each; and

- to upgrade heavy cil and/or bitumen used in agglomeration of coal to synthetic crude which would be suitable for pipelining and acceptable to refinories.

The outcome of the study was the development of the Agflotherm process (agglomeration, floatation and thermal treatment) which upgrades bw-rank $\infty$ al to high heating value solid fuel and heavy oil or bitumen to synthetic crude oil. Specific process research achievements related to the Agflotherm process are summarized below.

\section{Batch Test Studies}

Batch test procedures were developed for characterization of various coal and oil feedstock combinations for treatment in the Agflotherm process. The tests defined agglomeration and de-oiling parameters important in process optimization and operation. Selected results and products obtained in the process are shown in Table I. The product agglomerates from subbituminous coals had properties similar to those of westem Canadian bituminous coals, and product upgraded oils were similar to synthetic crudes produced from bitumen in other heavy oil thermal upgrading processes.

Table L Upgrading of low rank coal in Agflothem process: Heattourg Coal, Batch Tests.

\begin{tabular}{|c|c|c|c|c|c|}
\hline Mol & $\begin{array}{c}\text { loture, } \\
\times\end{array}$ & $\underset{\%}{A h,}$ & $\begin{array}{c}\text { Volatlo } \\
\text { matter, } \\
x\end{array}$ & $\begin{array}{c}\text { Fixed } \\
\text { exroon, } \\
x\end{array}$ & $\begin{array}{l}\text { Heating } \\
\text { valus } \\
\text { Eturs }\end{array}$ \\
\hline $\begin{array}{l}\text { Foed Coal } \\
\text { Groen }\end{array}$ & 16.3 & 24.6 & 30.3 & 28.8 & 7,840 \\
\hline $\begin{array}{l}\text { Agolome ates } \\
\text { Do-oibd r golon } \\
\text { (do-oiling tempe }\end{array}$ & $\begin{array}{c}8.2 \\
\text { nerates } \\
\text { orature) }\end{array}$ & 9.7 & 46.0 & 36.1 & 11,370 \\
\hline $\begin{array}{l}350^{\circ} \mathrm{C} \\
390^{\circ} \mathrm{C} \\
420^{\circ} \mathrm{C}\end{array}$ & $\begin{array}{l}4.1 \\
3.5 \\
3.5\end{array}$ & $\begin{array}{l}10.8 \\
12.5 \\
13.9\end{array}$ & $\begin{array}{l}35.8 \\
31.5 \\
24.6\end{array}$ & $\begin{array}{l}49.3 \\
52.5 \\
58.0\end{array}$ & $\begin{array}{l}11,580 \\
11,530 \\
11,320\end{array}$ \\
\hline
\end{tabular}

\section{Oll Recovery Studies}

The bench scale tests showed that it is technically feasible to recover upgraded oil from coal agglomerates, and that oil yield and properties are attractive enough to consider potential commercialization of the process. The upgraded oil had API gravity above 21, and significantly recuced sulphur and nitrogen content. Different cuts from the upgraded oil blends were found to have acceptable properties for refining, namoly:

- Napitha out $\left(\mathrm{C}_{5} / 175^{\circ} \mathrm{C}\right)$ was rich in aromatics and had a higher octane number than petroleumderived naphtha cuts. It would have to be hydrotreated before reforming (like all naphtha cuts from heavy oil syncrudes) and after treatment 
the blend could be used as a reformer feedstock for gasoline production.

- Jet fuel cut $\left(145 / 260^{\circ} \mathrm{C}\right)$ had a low smoke point and would also require some hydrotreatment.

- Diesel fuel blend $\left(177 / 343^{\circ} \mathrm{C}\right)$ would require hydrotreatment to reduce the contents of aromatics, sulphur and nitrogen.

- Vacuum gas oil cut $\left(+343^{\circ} \mathrm{C}\right)$ had low content of $\mathrm{Ni}$ and $V$, but high sulphur and nitrogen.

\section{Integrated Agglomeration Test Facility (IATF)}

Engineering and operational data were obtained for the Agflotherm process using the IATF specially reconfigured for the process (flowsheet \#ARC09). The plant produced well-formed, large agglomerates; however, in processing some feeds, difficulties were experienced with obtaining satisfactory performance of the pilot plant. These difficulties were primarily due to insufficient experiel ke and process information in areas such as:

- Kinetics of agglomeration for coals characterized by long inversion times.

- Optimization of the floatation conditions for microagglomerates obtained from low-rank coals which contained a high clay' concentration.

- Measurement of slumy tlow, stumy solid concentration, density, etc.

- Process control system.

The pilot piant products were de-oiled and sent for laboratory combustion tests. The products were found to have good handling, storage and combustion characteristics including less susceptibility to spontaneous combustion than the "parent" coals.

\section{Feasibility of the Agflothem Process}

A conceptual design for the Agflotherm process was developed to upgrade $\overline{2} .8$ mittion metric tonnes of ROM subbituminous $c 0$ al and 448 thousand tonnes of heavy oil in Alberta, Canada. The plant production was estimated at 2.06 million tonnes per year of deoiled agglomerates with a heating value of $26.7 \mathrm{Gu} / \mathrm{t}$ $(11,300 \mathrm{Btu} / \mathrm{b})$ and 370 thousand tonnes of syncrude with API gravity of 21. The plant cost was estimated at \$Cdn 113.6 million, operating cost at $\$ C d n 91$ million per year and working capital at $\$ C$ dn 17.2 million. Based on 1989 feedstock and product prices (\$Cdn 12/ of coal, \$Cdn \$3.4/ bitumen, \$Cdn 33/ product agglomerates and \$Cdn
124.24 syncrude), the economic analyses of the plant showed DCF ROR after tax equal to 11.1 percent.

The key cost factors in the Agflotherm were the $\infty$ st of heavy oil and $\infty$ al, the yield and price of $\infty$. product oil, and the price of de-oiled agglomerates. The projected DCF ROR of 11.1 percent was contingent on the technical feasibility of a novel de-oiling process based on high temperature extrusion of coal-oil paste (described in Volume 1).

\section{Beneficiation of High Sulphur Bituminous Coals}

The objective of the bituminous coal project was the development of technology which would:

- Rernove pyritic sulphur from high sulphur bituminous coals.

- Reduce mineral matter content in bituminous coals to 10 percent or less.

- Increase heating value of the processed coals above 13,000 Btu/lb.

The result of the process research was the development of a process, the Aglofloat process (agglomeration and floatation), capable of meeting all of the above listed project objectives. Specific process issues related to the performance and economics of the Aglofloat are discussed below.

\section{Batch Test Studies}

Laboratory tests were carried out to evaluate key factors influeincing the Aglofloat process performance. Nine coals (ROM and coal preparation by-products) from the eastem U.S. and western Canada were studied. Typical results obtained with U.S. coals are shown in Figure $\mathrm{I}$. The results were obtained using single-stage and two-stage (with regrinding and reprocessing of the product) batch processing. The tests show good combustibles recovery and pyrite rejection ai bridging oil concentrations as low as 0.5 percent. For westem Canadian coals, however, the Aglofloat procedures had to be modified and the amount of bridging oil had to be increased to 3 percent or more. 


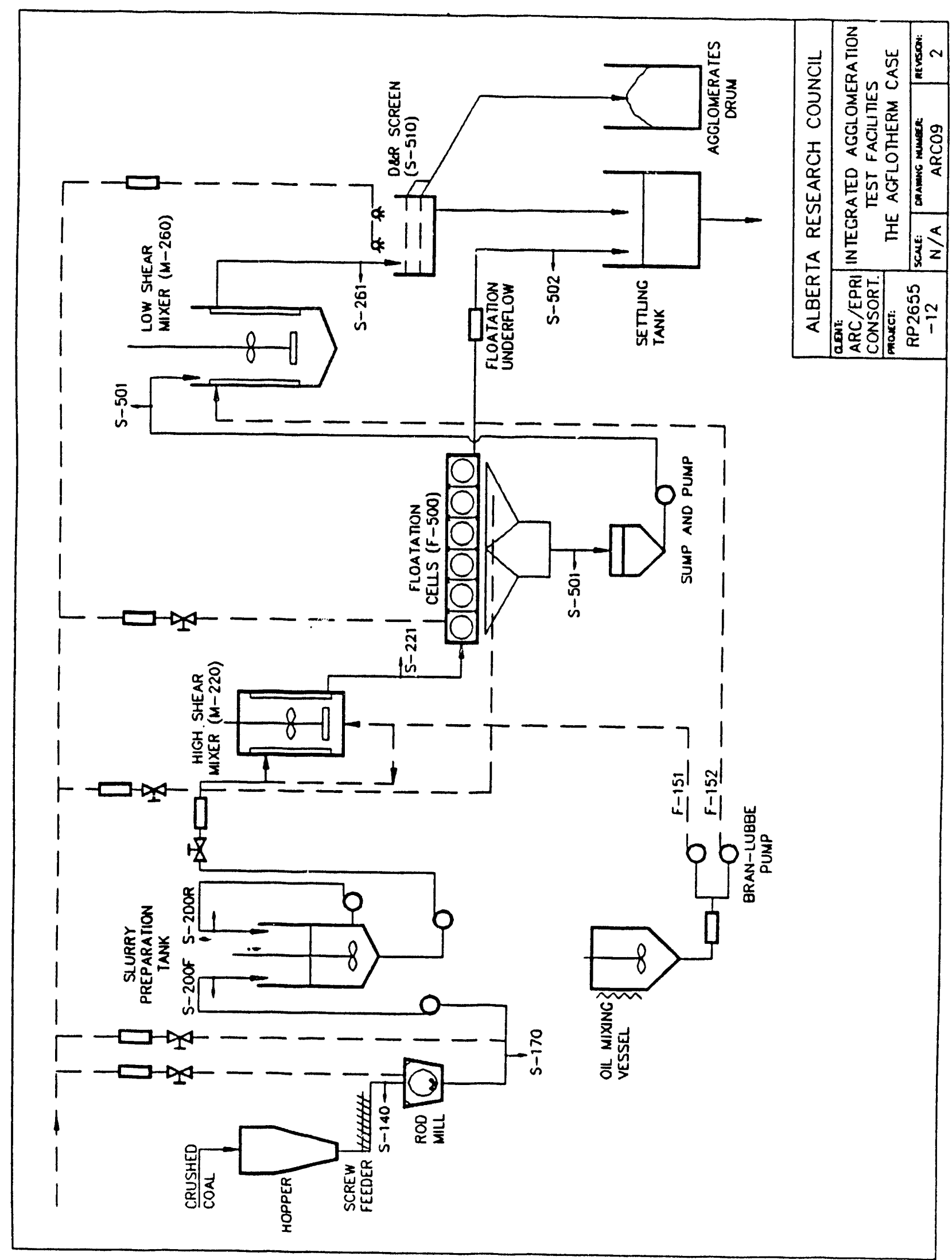



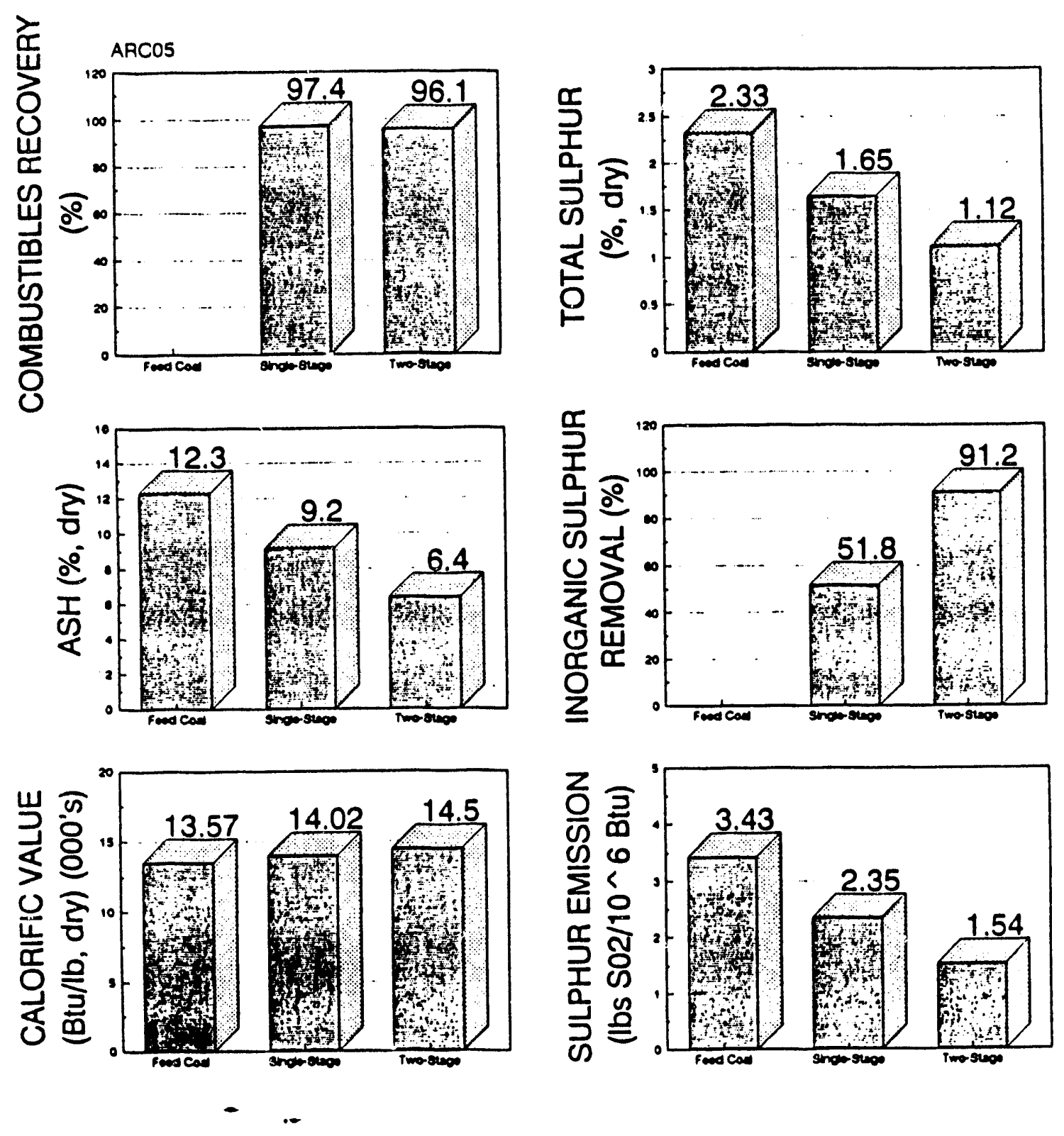

Figure I. Cleaning of upper Freeport Coal by Aglofluat process.

\section{Continuous Pyrite Removal Unit (CPRU)}

The feasibility of using hydraulic ard flume separators for removal of pyrite from bituminous coals agglomerates was evaluated using a $5 \mathrm{~kg} / \mathrm{h}$ bench scale CPRU. Both units showed reduction of pyrite in coal product; however, because of better operability, a system with a hydraulic separator only was chosen for the Aglofloat process. Tests using the CPRU with U.S. coals indicated that at the best conditions tested, the total sulphur reduction ranged from 50 to 55 percent, and the nyritic sulphur reduction ranged from 72 to 77 percent, while the ash reduction ranged from 82 to 86 percem. The information obtained in the CPRU was successfully used in the scale-up of the hydraulic pyrite separator in the pilot plant (IATF). 


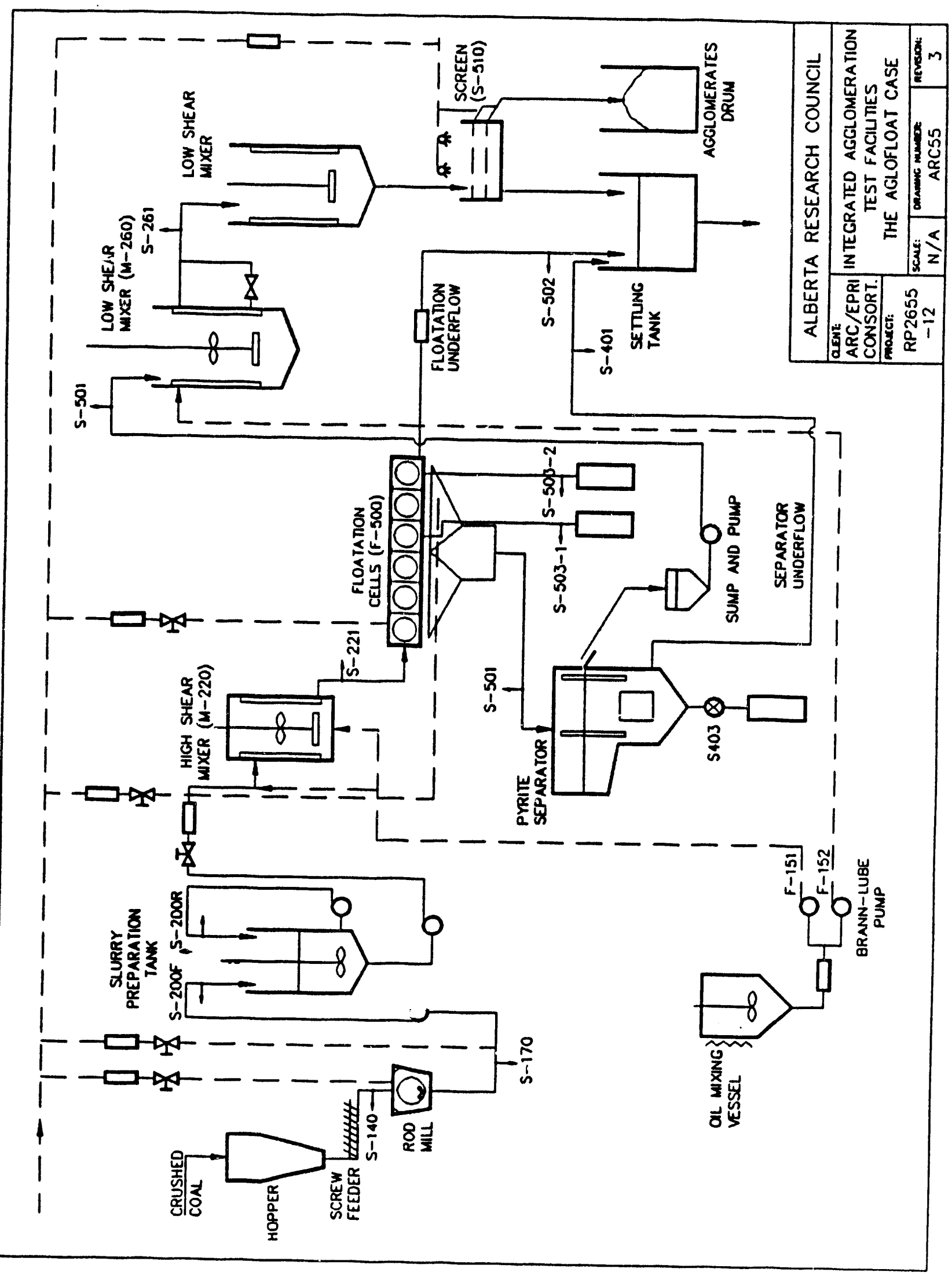




\section{Large Pilot Plant Tests (IATF)}

The hydraulic pyrite separator developed was incorporated into the Integrated Agglomeration Test Facility pilot piant in the Aglofloat process configuration (flowsheet \#ARC55). The IATF results confirmed that well-formed agglomerates reduced in sulphur and mineral matter can be obtained in the process. Large, 0.8 to $3.0 \mathrm{~mm}$ agglomerates could be obtained at bridging oil concentrations as low as 12 percent (d.a.f. feed coal). The agglomerates had a heating value above $13,000 \mathrm{Btu} / \mathrm{lb}$, ash content of less than 10 percent and pyritic sulphur content reduced up to $90 \mathrm{p}$ iscent.

Considerable effort went into improving the process. Equipment efficiency and performance was evaluated for unit operations such as floatation of coal flocs, hydraulic pyrite separation and size enlargement of microagglomerates. One of the key issues studied was the effect of process operating parameters on process stability anu fesformarce. The key Aglofloat process parameters wi:re identified; however, more experimentation will be necessary to understand the process and to further reduce the amount of bridging oil required.

\section{Feasibility of the Aglofloat Process}

The pilot plant work for the Aglofloat process was used as a basis for the conceptual design of an aglofloat plant capable of processing 2.8 million short tons of eastem U.S. bituminous coal to 2.74 million tons of agglomerates. The economic analysis of the process estimated the plant capital cost at \$U.S. 61.5 million, operating cost at \$U.S. 121.0 million per year and working capital at \$U.S. 22.2 million. The product cost was calculated at \$U.S. 52.85 per ton at DCF ROR equal 15 percent (after tax) and coal price of \$U.S. 27fitob plant. The key cost elements determining the product price were the coal price, the amount and price of oil, and to a lesser extent the operating and capital costs.

Variance analysis pertormed on the coal price suggested that using the Agbiloat to process coal refuse (coal price $=\$$ U.S. O/) could produce a clean coal product at \$U.S. 25.26 per ton. Such a product would be competitive with the current cost of lowand medium-sulphur coals in the eastem U.S. (priced at \$U.S. 20 to \$U.S. 28 per ton).

\section{Cleaning of Tar refuse and Hydrocarbon Contaminated Soils}

The objective of the Clean Soil study was to develop technology which would:

- Clean up contaminated soils at manufactured gas plant sites, coking plant sites, benzol plant sites, etc.

- Clean up contaminated soils from oil spills, oily wastes pits, and other hydrocarbon contaminated spills.

- Treat heavy oil wastes and emulsions from heavy oil recovery and upgra ting plants.

The project led to the de.elopment of the Clean Soil process which cleans contaminated soils to a level of $1000 \mathrm{ppm}$ (0.1 percent) or less, and yields by-product agglomerates which contain the hydrocarbon contaminants and are suitable for combustion in industrial boilers. Specific achievements related to the process performance and evaluation are summarized below.

\section{Batch Test Studies}

A rapid laboratory screening method for characterization of various contaminated soils for treatment in the Clean Soil process was developed. The tests performed suggest that a wide range of contaminant types and concentrations in the soil can be treated by the process. The concentration of residual contaminants in the clean soil was reduced to 0.1 percent or less (Table II). The key properties of the contaminated soil influencing the process performance were identified as:

- The amount and composition of the hydrocarbon contaminants.

- The particle size and particle size distribution of the soil.

- The presence of other materials in the contaminated soil capable of adsorbing the contaminants, e.g., rske.

Depending on the s sil characteristics, the Clean Soil process procedures can be readily modified to achieve the best process pertormance. 
Table Il. Clean-up of contaminated soil using Clean Soil process: Overall Material Balance for Site $\# 1-1$, Batch Tests.

\begin{tabular}{|c|c|c|}
\hline Type of contaminant & $\begin{array}{l}\text { Coniaminant } \\
\text { concentration, } \%\end{array}$ & $\begin{array}{l}\text { nant } \\
\text { llon, \% } \\
\text { Processed } \\
\text { soll } \\
\end{array}$ \\
\hline $\begin{array}{l}\text { Tar } \# 1(1) \\
\text { Tar } \# 1(2) \\
\text { Tar } \# 2(2) \\
\text { Tar } \# 2(8) \\
\text { Tar } \# 1-1 \\
\text { Tar } \# 2-2 \\
\text { Heavy Oil } \\
\text { Oil (light) Spills } \\
\text { Gasoline Spills } \\
\text { Oil (heavy) Spills I } \\
\text { Oil (heavy) Spills II }\end{array}$ & $\begin{array}{r}8.6 \\
1.2 \\
66.9 \\
0.7 \\
5.6 \\
10.6 \\
8.7 \\
2.0 \\
3.1 \\
43.0 \\
0.2\end{array}$ & $\begin{array}{l}0.07 \\
0.00 \\
0.10 \\
0.10 \\
0.07 \\
0.17 \\
0.04 \\
0.17 \\
0.06 \\
0.08 \\
0.00\end{array}$ \\
\hline
\end{tabular}

- Guidelines accepted by many regulatory agencies in North America require that the rssidual concentration of petroleum derived contaminants does not exceed 1000 ppm (0.1 percent) in the clean soil.

\section{Large Pilot Plant (IATF)}

The Integrated Agglomeration Test Facility was reconfigured for the Clean Soil process operation (flowsheet \#ARC20). The pilot plant runs provided information on process control and performance of each unit operation at steady-state conditions. For some feeds, however, less than desired performance of the IATF was obtained because limited process information was available on the kinetics of agglomeration and the separation of contaminants from the cleaned soil.

A large sample of product agglomerates produced in the IATF was tested for its handling, grinding and combustion characteristics by Combustion Engineering, Inc. The tests showed that combustion performance and emissions for aggiomerates from tar refuse were similar to combustion performance of HVB coal used in agólomeration.

\section{Feasibility of the Clean Soil Process}

The commercial feasibility of using the Clean Soil process for treatment of oily waste from bitumen upgrading was evaluated. The plant was assumed to be a mobile plant bcated in Alberta and capable of processing 30,500 tonnes of oily wastes per year. Depending on whether pulverized coal was purchased or prepared at the plant site, the plant capital cost was estimated at \$Cdn i.8 and \$Cdn 2.06 mil- lions, respectively. The cost of cleaning oily waste was estimated at \$Cdn 31.39n, for a case where the market for agglomerates exists near the plant, and at \$Cdn $46.97 \mathrm{~A}$ for a case where agglomerates would have to be shipped for sale. The costs indicated are within the range of current costs of waste disposal (\$Cdn 25 to \$Cdn 35 per ton, for hauling and spreading). However, since spreading is likely to be unacceptable as a disposal method in the future, the Clean Soil process offers a viable new technology for oily waste disposal.

\section{Conclusions}

Three new processes were developed in the first two and one-half years of the Consortium Coal Processing Development Program based on ARC's advanced spherical agglomeration research. The preliminary evaluation of these processes suggest that the most promising opportunities and their constraints for further development, are:

- co-upgrading of low rank coal and heavy oil;

- beneficiation of bituminous coal refuse and ROM coal; and

- clean-up of contaminated soil.

The major technical and economic constraints which must be solved for each process are:

- the technical feasibility of coal-oil paste extrusion in co-upgrading of coal and heavy oil;

- the reduction of the amoumt of bridging oil required for production of large size agglomerates in beneficiation of bituminous coals; and

- the optimization of the reprocessing steps in cleaning of some contaminated soils.

The results described in Volumes I, II, and III of this report summarized achievements completed prior to December 31, 1989. Since that time, however, further improvernemts in process performance were attained and presented to the Consorium members. These results will be described in detail in the updated reports for each process.

Each of these technology opportunities has advanced in this year (1990) of the consortium program, to a stage where it can be pursued by smaller R\&D consortia comprised of members with an interest in one or two of the technology areas only. It is recommended that future work in this program be pursued by such consortia addressing each technology area separately. 


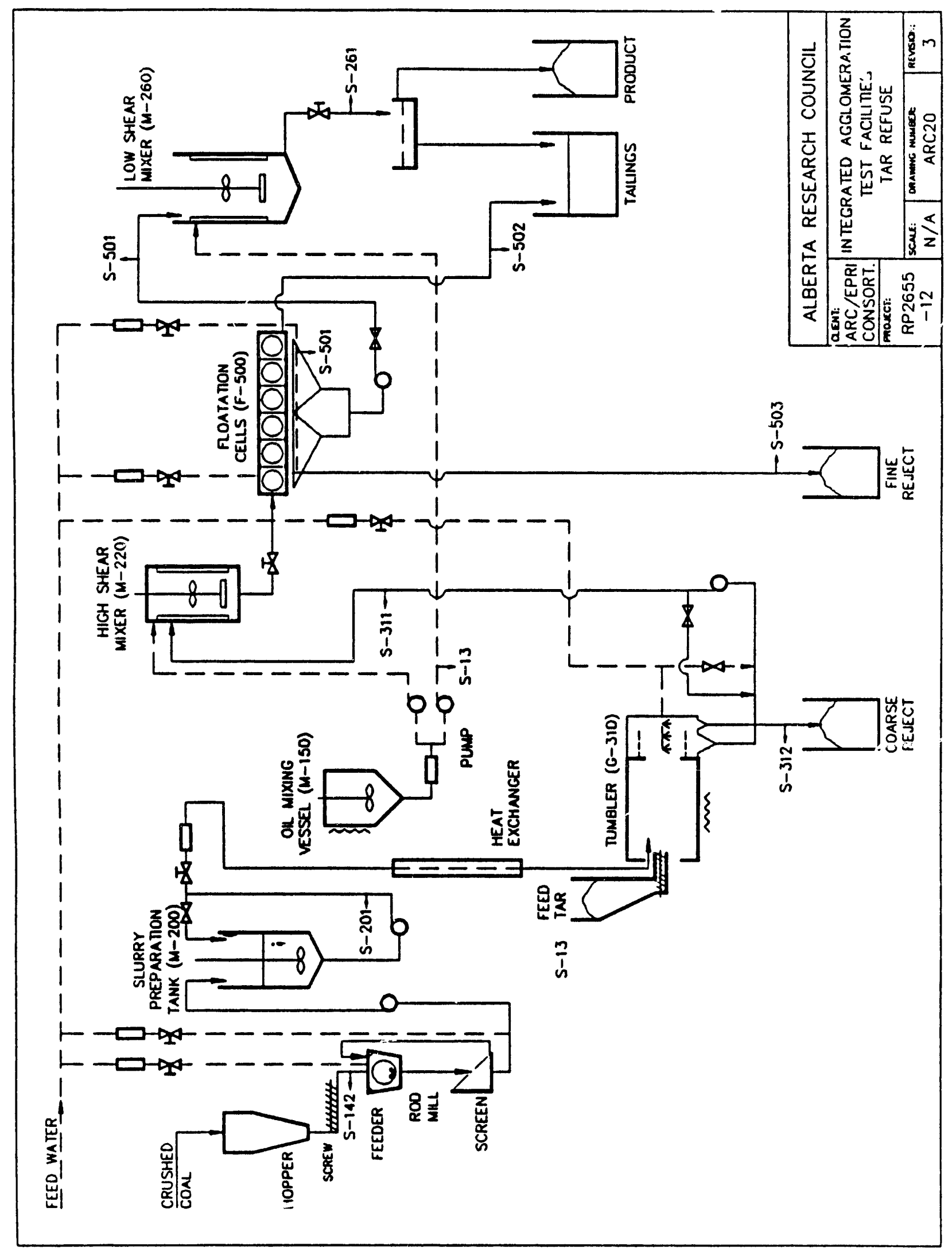




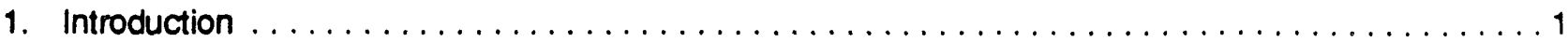

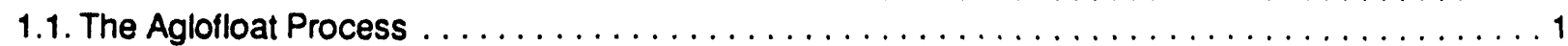

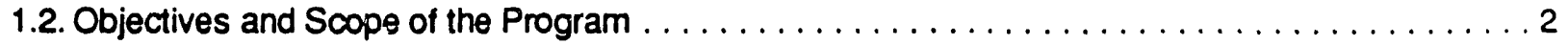

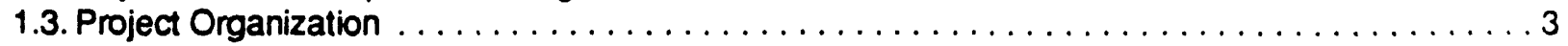

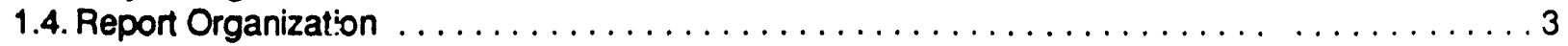

2. Bench Scale Characterization of Coals and Oils for the Agloiloat Process $\ldots \ldots \ldots \ldots \ldots \ldots \ldots$

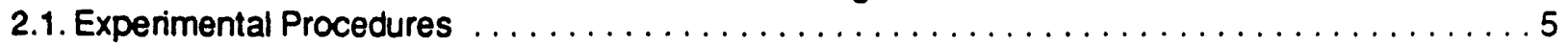

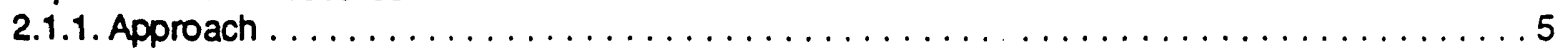

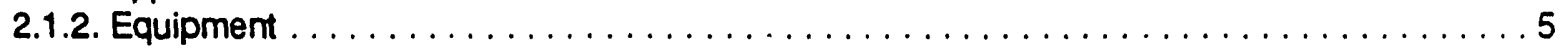

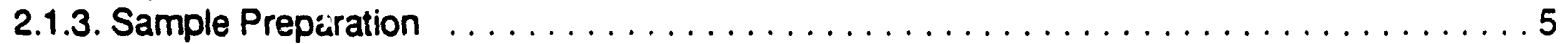

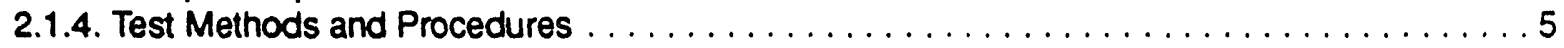

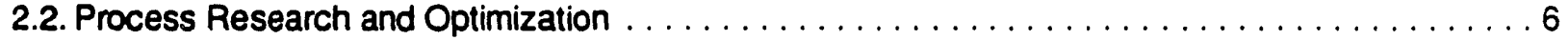

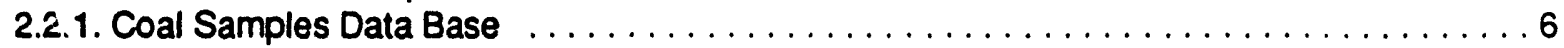

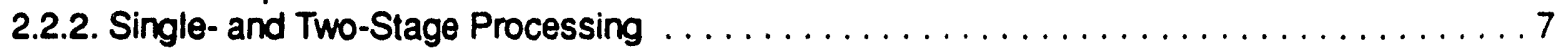

2.2.3. Effect of Sample Preparation on Ash and Pyrite Rejection $\ldots \ldots \ldots \ldots \ldots \ldots \ldots \ldots$

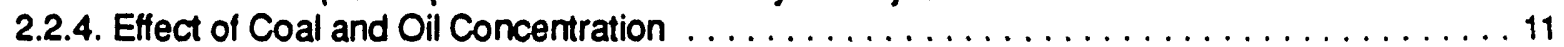

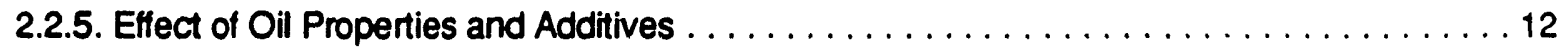

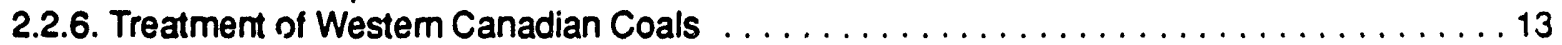

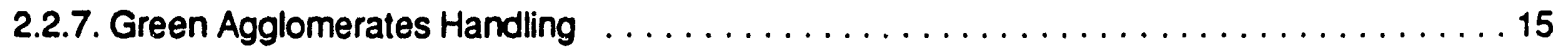

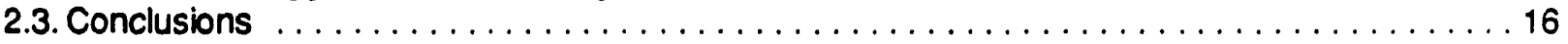

3. Design Studies of Agglomeration Mechanisms $\ldots \ldots \ldots \ldots \ldots \ldots \ldots \ldots \ldots \ldots \ldots \ldots \ldots$

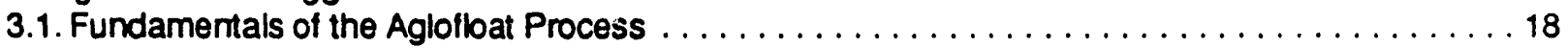

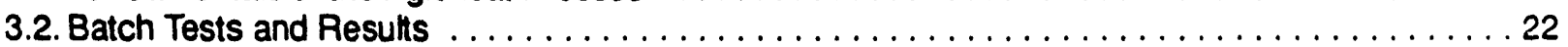

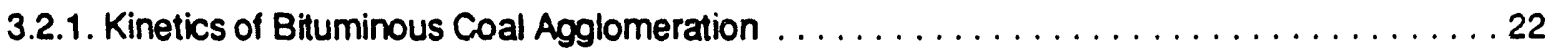

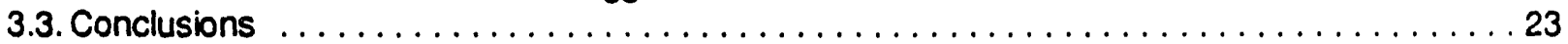

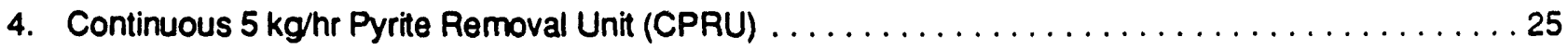

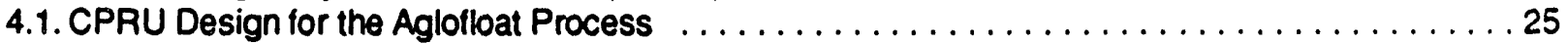

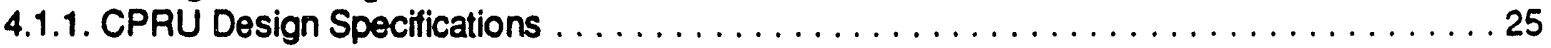

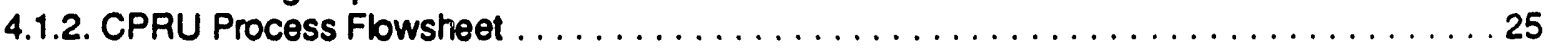

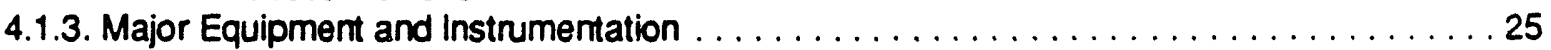

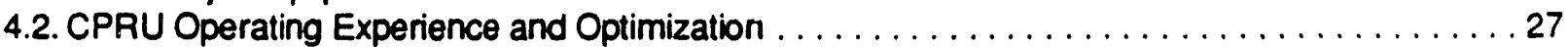

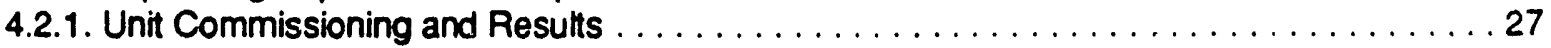

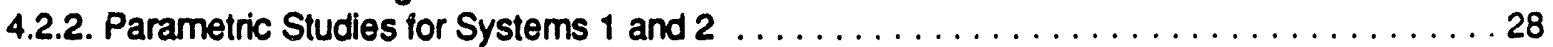

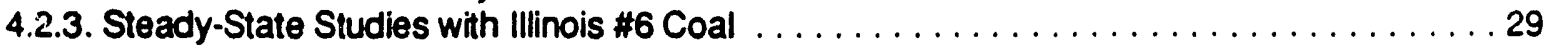

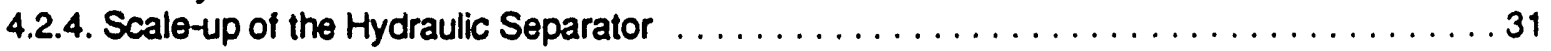

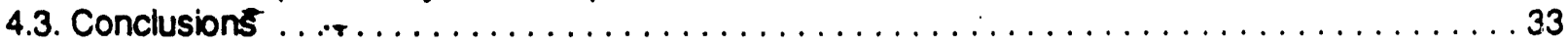

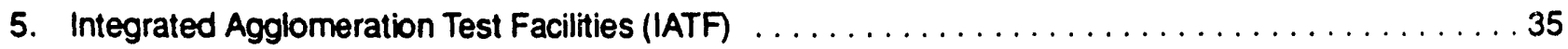

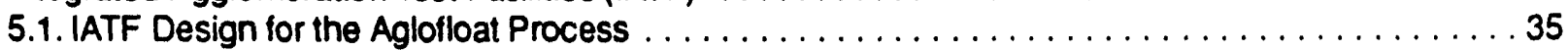

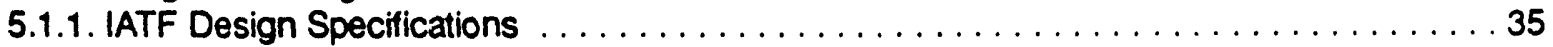

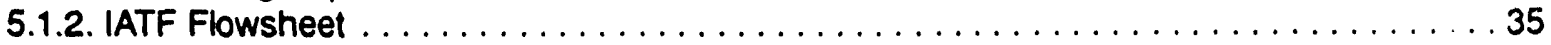

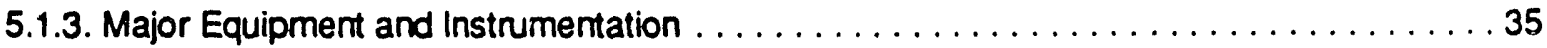

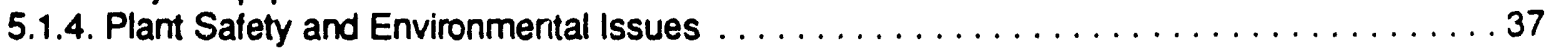

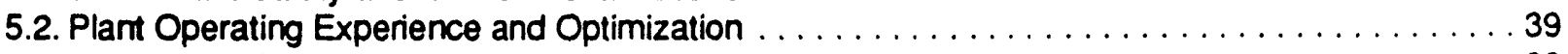

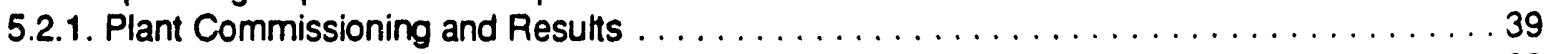

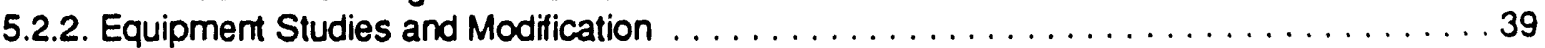

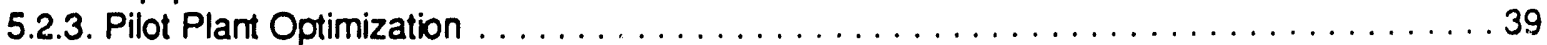




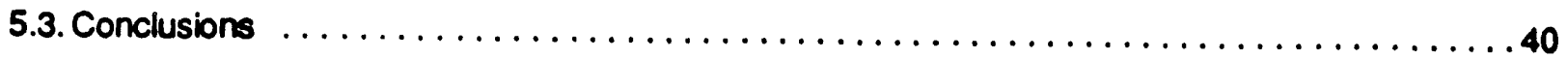

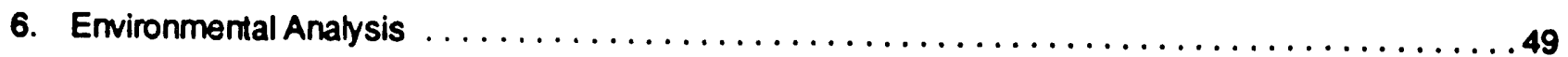

7. Conceptual Design and Cost Analysis of an Integrated Commercial Plant for the Aglofloat Process .. 50

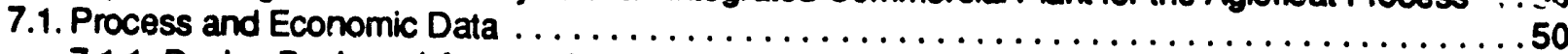

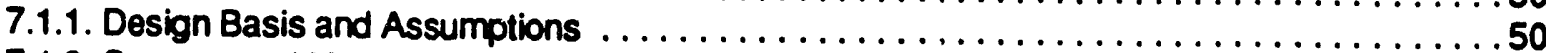

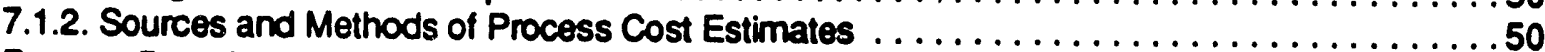

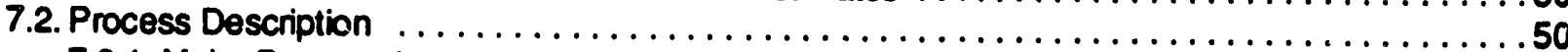

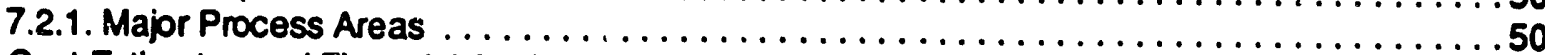

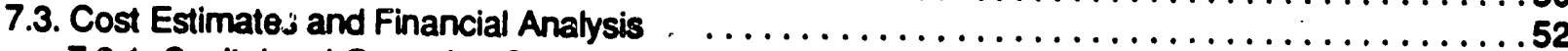

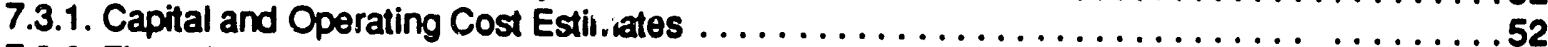

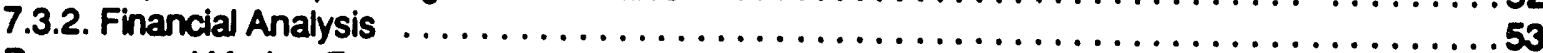

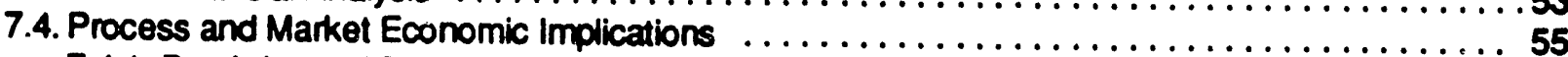

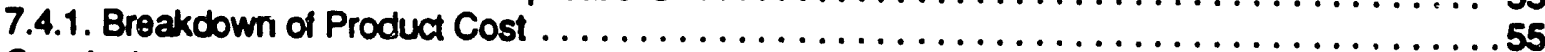

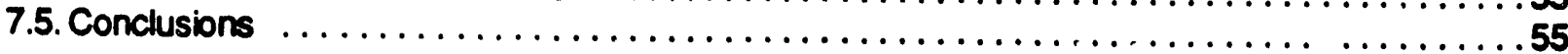

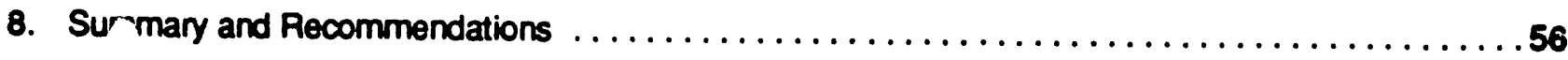

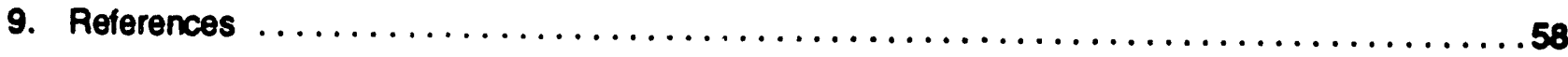

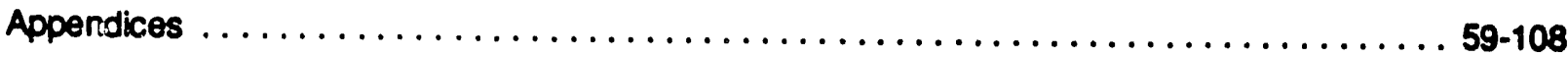

List of Tables

1.1. Comparison of Aglofloat to other Coal Desulphurization Process $\ldots \ldots \ldots \ldots \ldots \ldots \ldots \ldots \ldots \ldots$

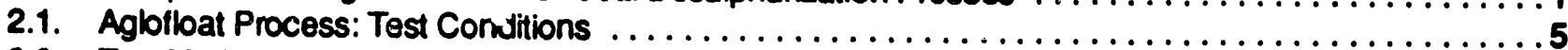

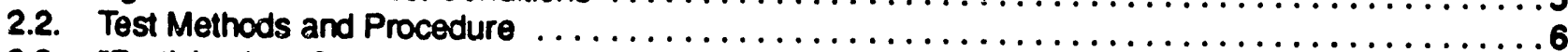

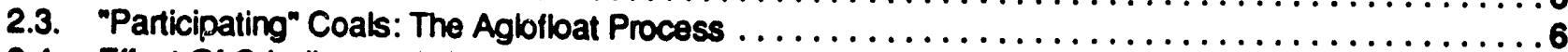

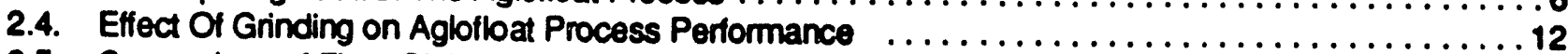

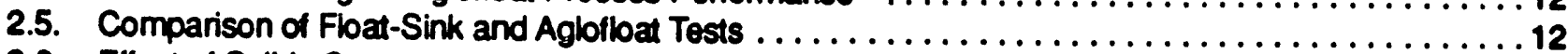

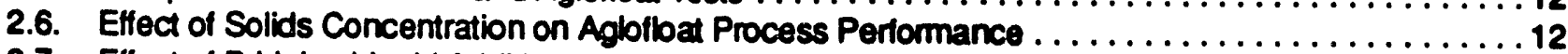

2.7. Effect of Bridging Liquid Addition on Aglofloat Process Performance $\ldots \ldots \ldots \ldots \ldots \ldots \ldots \ldots \ldots \ldots \ldots$

2.8. Effect of Bridging Liquid Addition on Aglofloat Process Performance $\ldots \ldots \ldots \ldots \ldots \ldots \ldots \ldots \ldots \ldots 12$

2.9. Effect of Bridging Liquid Composition on Aglofloat Process Performance $\ldots \ldots \ldots \ldots \ldots \ldots \ldots \ldots \ldots \ldots$

2.10. Effect of Bridging Liquid Composition on Aglofloat Process Performance $\ldots \ldots \ldots \ldots \ldots \ldots \ldots \ldots$

2.11. Effect of Bridging Liquid Composition on Aglofloat Process Performance $\ldots \ldots \ldots \ldots \ldots \ldots \ldots \ldots \ldots 13$

2.12. Beneficiation of Byron Creek Fines by Agbofbat Process $\ldots \ldots \ldots \ldots \ldots \ldots \ldots \ldots \ldots \ldots \ldots \ldots \ldots \ldots$

2.13. Beneficiation of Byron Creek Fines by Aglofbat Process $\ldots \ldots \ldots \ldots \ldots \ldots \ldots \ldots \ldots \ldots \ldots \ldots \ldots$

2.14. Recovery of Combustble Material from Byron Creok Fines by Aglofbat Process $\ldots \ldots \ldots \ldots \ldots \ldots 14$

2.15. Beneficiation of Byron Creek Fines by Aglofbat Process $\ldots \ldots \ldots \ldots \ldots \ldots \ldots \ldots \ldots \ldots \ldots \ldots 14$

2.16. Beneficiation of Byron Creek Fines - Effect of Additional Grinding on Deashing . . . . . . . . . 14

2.17. Beneficiation of Byron Creek Reject by Single-Stage Aolofbat Process $\ldots \ldots \ldots \ldots \ldots \ldots \ldots \ldots \ldots$

2.18. Effect of Process Performance on Product Quality $\ldots \ldots \ldots \ldots \ldots \ldots \ldots \ldots \ldots \ldots \ldots \ldots \ldots \ldots \ldots$

2.19. Recovery of Combustble Material from Precipitator Dust $\ldots \ldots \ldots \ldots \ldots \ldots \ldots \ldots \ldots \ldots \ldots \ldots \ldots \ldots$

2.20. Beneficiation of Obed Washed Coal by Aglofloat Process $\ldots \ldots \ldots \ldots \ldots \ldots \ldots \ldots \ldots \ldots \ldots \ldots$

2.21. Beneficiation of Obed Washed Coal by Aglofloat Process $\ldots \ldots \ldots \ldots \ldots \ldots \ldots \ldots \ldots \ldots \ldots \ldots$

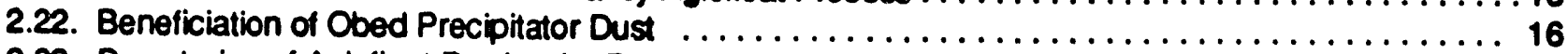

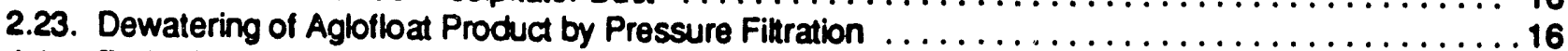

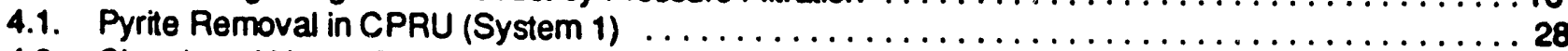

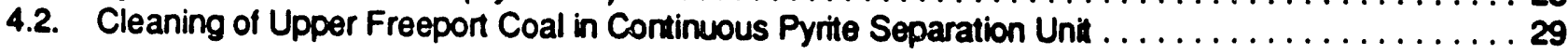


4.3. Cleaning of Upper Freeport Coal in Continuous Pyrite Separation Unit $\ldots \ldots \ldots \ldots \ldots \ldots \ldots$

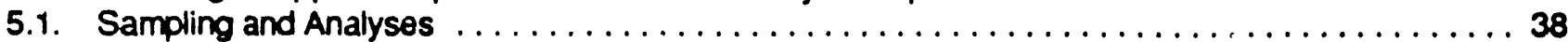

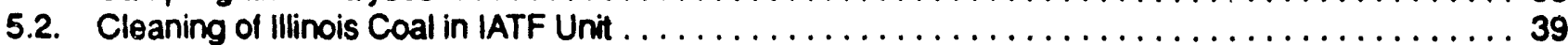

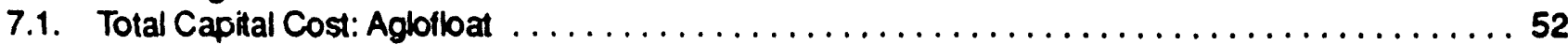

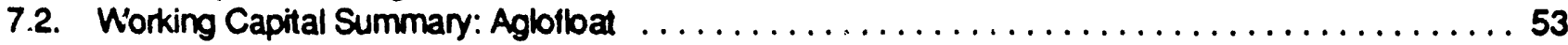

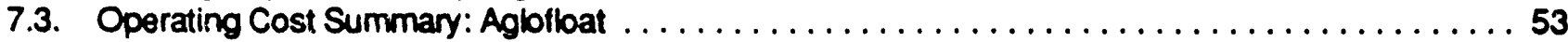

7.4. Summary of Plant Revenue and Costs over the Plant Life: Aglofloat $\ldots \ldots \ldots \ldots \ldots \ldots \ldots \ldots 5$

7.5. Breakdown of the Estimated Cost for Agglomerates $\ldots \ldots \ldots \ldots \ldots \ldots \ldots \ldots \ldots \ldots \ldots \ldots$

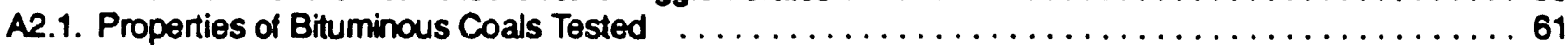

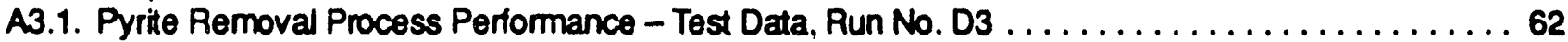

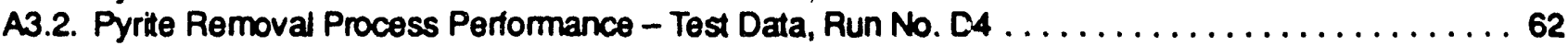

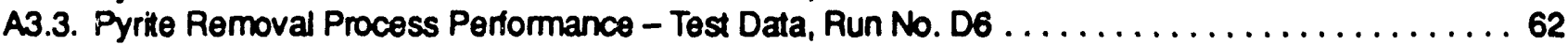

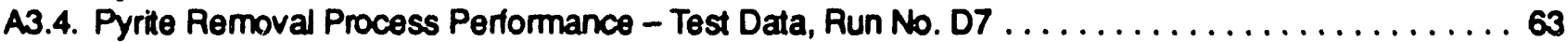

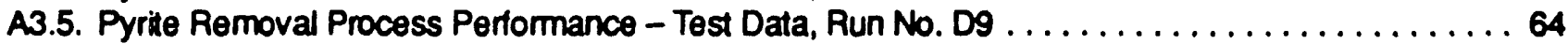

A5.1. Annual Operating Cost Factors $\ldots \ldots \ldots \ldots \ldots \ldots \ldots \ldots \ldots \ldots \ldots \ldots \ldots \ldots \ldots \ldots$

A5.2. Factors used for Estimating Capital Cost of Different Areas $\ldots \ldots \ldots \ldots \ldots \ldots \ldots \ldots \ldots \ldots$

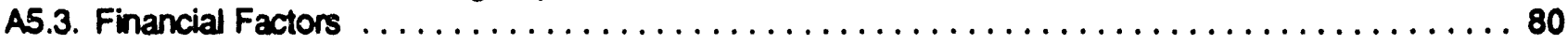

A5.4. Prices and Rates for Chemicals, Fuels, Utilities, etc. $\ldots \ldots \ldots \ldots \ldots \ldots \ldots \ldots \ldots \ldots \ldots$

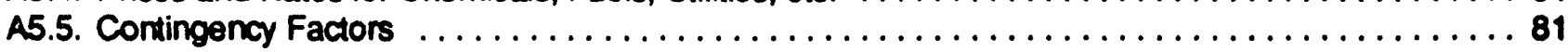

A5.6. Summary of Process Eloctrical Requirements $\ldots \ldots \ldots \ldots \ldots \ldots \ldots \ldots \ldots \ldots \ldots \ldots \ldots$

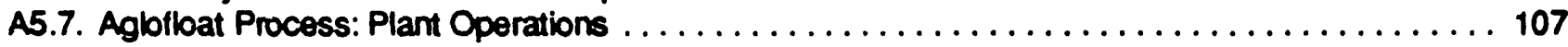

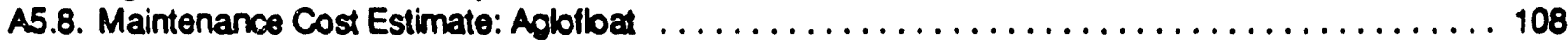

A5.9. Analysis of Design Rom Coal, Coal Retuse and Dried Clean Coal Product . . . . . . . . . 108

\section{List of Figures}

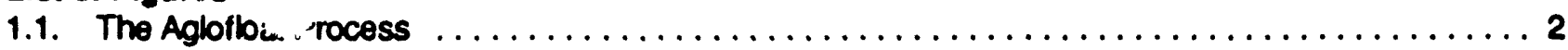

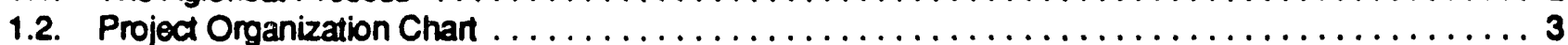

2.1. Schematic Representation of Agbfloat Batch Procedures $\ldots \ldots \ldots \ldots \ldots \ldots \ldots \ldots \ldots \ldots 6$

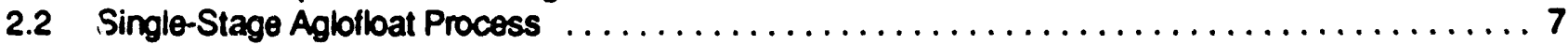

2.3. Iwo-Stage Aglofloat Process with Interstage Wet Grinding $\ldots \ldots \ldots \ldots \ldots \ldots \ldots \ldots \ldots \ldots 7$

2.4. Cleaning of Pittsburgh Seam Coal by Aglofloat Process $\ldots \ldots \ldots \ldots \ldots \ldots \ldots \ldots \ldots \ldots \ldots 8$

2.5. Cleaning of Illinois No. 6 Coal by Agbfloat Process $\ldots \ldots \ldots \ldots \ldots \ldots \ldots \ldots \ldots \ldots \ldots$

2.6. Cleaning of Indiana $V$ Coal by Aglofload Process $\ldots \ldots \ldots \ldots \ldots \ldots \ldots \ldots \ldots \ldots \ldots \ldots$

2.7. Cleaning of Upper Freeport Coal by Aglofbat Process $\ldots \ldots \ldots \ldots \ldots \ldots \ldots \ldots \ldots \ldots \ldots \ldots \ldots$

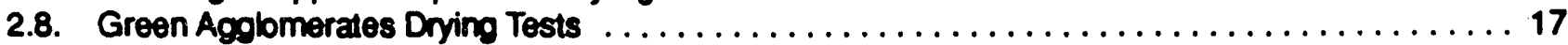

3.1. Schematic Representation of Aggiomerates Formation $\ldots \ldots \ldots \ldots \ldots \ldots \ldots \ldots \ldots \ldots \ldots$

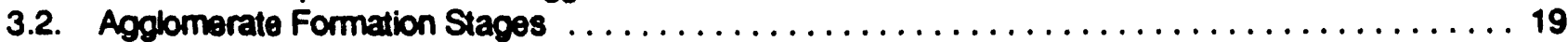

3.3. Relationship Between Growth Factor, Growth Periods and Oil Saturation States .......... 20

3.4. Growth Regirees for the Agglomeration Process $\ldots \ldots \ldots \ldots \ldots \ldots \ldots \ldots \ldots \ldots \ldots \ldots \ldots$

3.5. Relationship Betwien Growth Factor and Oi Concentration $\ldots \ldots \ldots \ldots \ldots \ldots \ldots \ldots \ldots \ldots 21$

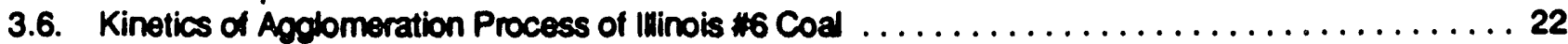

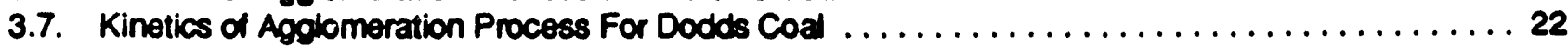

3.8. Influence of Oil Addition on Growth Agglomerates from Illinois Coal (Mixer M-260) $\ldots \ldots \ldots \ldots 22$

3.9. Batch Tests on Kinetics of itio Agglomeration Processs for Ohio Coal . . . . . . . . . . . . . 23

3.10. Influence of Mixing Rate and Desliming on Kinetics of Agglomeration for Highvale Coal . . . . . 24

4.1. Continuous Pyrite Removal Bench Unit (System 1) $\ldots \ldots \ldots \ldots \ldots \ldots \ldots \ldots \ldots \ldots \ldots$

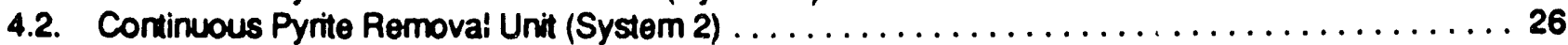

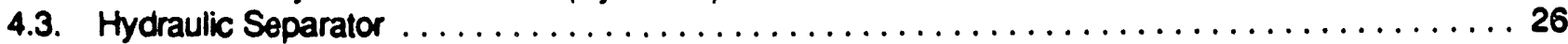

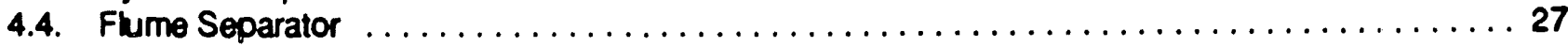


4.5. Cleaning of Upper Freeport Coal by Aglo" oat Process in Continuous Pyrite

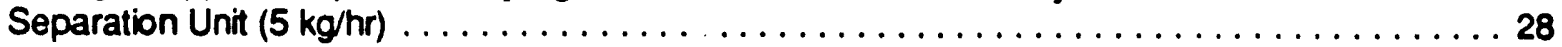

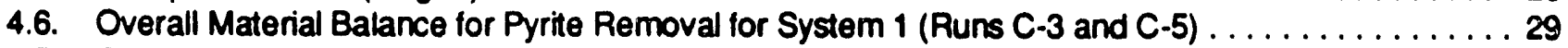

4.7. Overall Material Balance for Pyrite Removal System with Fume Separator $\ldots \ldots \ldots \ldots \ldots$

4.8. Overall Material Balance for Pyrite Removal in Systems with Bypassed

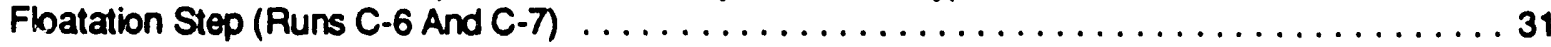

4.9. Effect of Oil Concentration on Combustible Matter Recovery $\ldots \ldots \ldots \ldots \ldots \ldots \ldots \ldots \ldots \ldots 31$

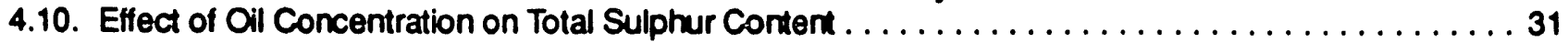

4.11. Effect of Oil Concentration on Pyritic Sulphur Content $\ldots \ldots \ldots \ldots \ldots \ldots \ldots \ldots \ldots \ldots \ldots \ldots \ldots$

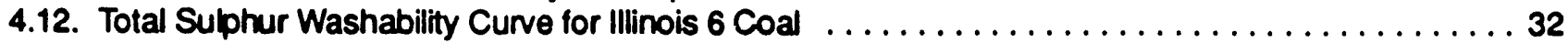

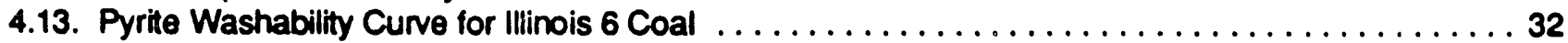

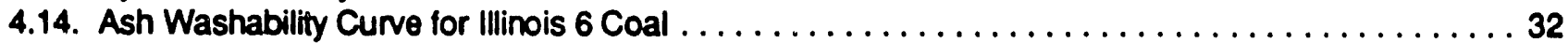

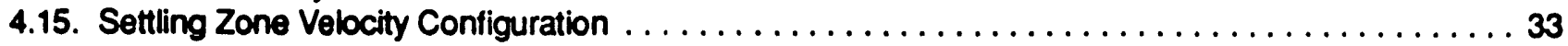

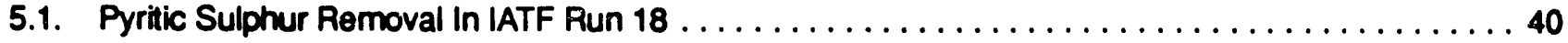

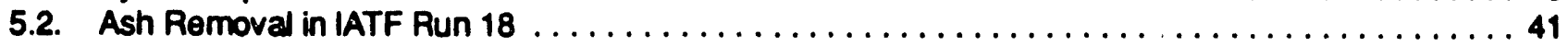

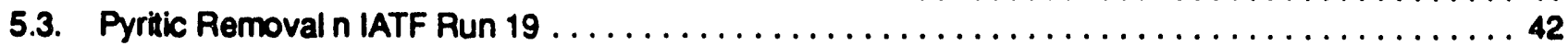

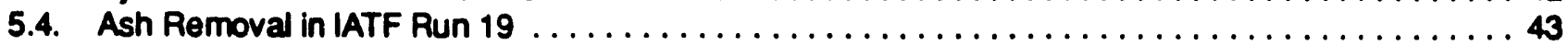

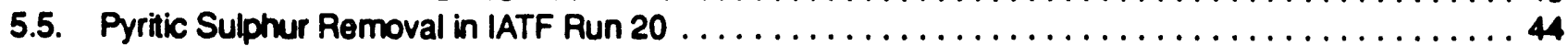

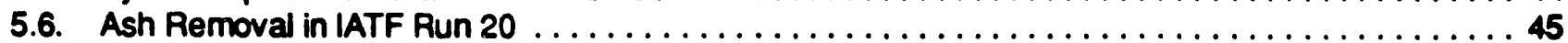

5.7. IATF Runs: Effect of Oil Concentration on Pyritic Sulphur Rernoval $\ldots \ldots \ldots \ldots \ldots \ldots \ldots \ldots \ldots$

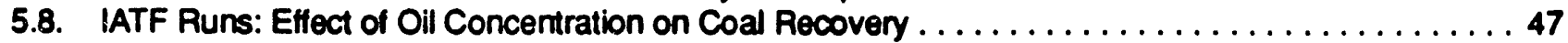

5.9. IATF Runs: Recovery Curves for Floatation and Pyrite Separation Units $\ldots \ldots \ldots \ldots \ldots \ldots \ldots$

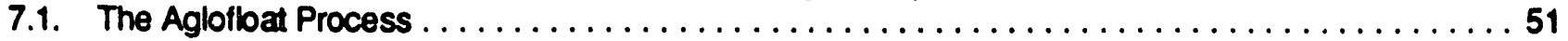

7.2. The Effect of Oil Concemration on Product Price (Aglofloat) $\ldots \ldots \ldots \ldots \ldots \ldots \ldots \ldots \ldots \ldots$

7.3. The Effect of Capital and Operating Cost on Product Price (Aglofloat) $\ldots \ldots \ldots \ldots \ldots \ldots \ldots 54$

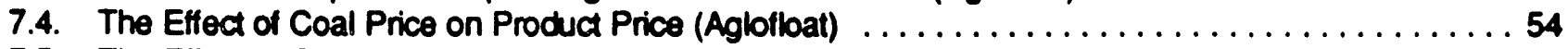

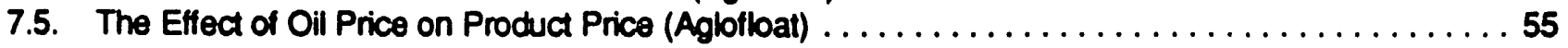

A3.1. Fbatation Kinetic Test Results - Influence of Floatation Time on Recovery ...........64

A3.2. Floatation Cells Geometric Configuration $\ldots \ldots \ldots \ldots \ldots \ldots \ldots \ldots \ldots \ldots \ldots \ldots \ldots$

A4.1. Variation of the Main Process Parameters During Run $1 \ldots \ldots \ldots \ldots \ldots \ldots \ldots \ldots \ldots$

A4.2. Variation of Main Process Parameters During Run $5 \ldots \ldots \ldots \ldots \ldots \ldots \ldots \ldots \ldots$

\section{List of Flowsheets}

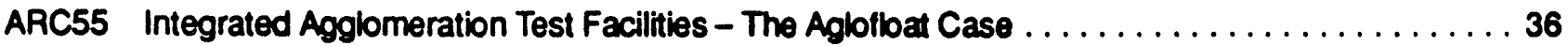

ARC47 Coal Delivery, Storage and Crushing - Area $100 \ldots \ldots \ldots \ldots \ldots \ldots \ldots \ldots \ldots \ldots \ldots$

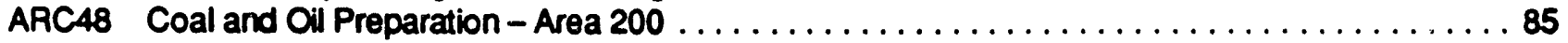

ARC72 Agglomeration and Separation-Area $300 \ldots \ldots \ldots \ldots \ldots \ldots \ldots \ldots \ldots \ldots \ldots \ldots$

ARC73 Agglomeration and Separation - Area $400 \ldots \ldots \ldots \ldots \ldots \ldots \ldots \ldots \ldots \ldots \ldots \ldots$

ARC71 Water Treatment -Area $500 \ldots \ldots \ldots \ldots \ldots \ldots \ldots \ldots \ldots \ldots \ldots \ldots \ldots \ldots \ldots \ldots$

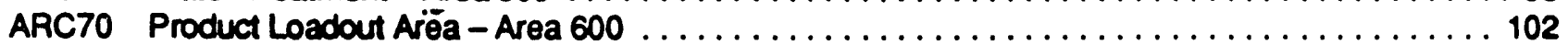




\section{Introduction}

\subsection{The Aglofloat Process}

The Aglofloat process is an advanced spherical agglomeration process capable of beneficiaiting high ash and sulphur, bituminous coals to clean fuel with a heating value above 13,000 Btu/lb, ash content of less than 10 percent, and significantly reduced (up to 95 percent) pyritic sulphur content.

The process and product streams are illustrated in Figure 1.1. First, run-of-mine coal is crushed, pulverized to $-0.6 \mathrm{~mm}$ (-28 mesh) and sturried with recycle water. At the same time, crude oil is mixed with diesel fuel to form a bridging oil. The coal slurry and bridging oil are combined in a high shear mixer where coal and nil form microagglomerates about $0.2 \mathrm{~mm}$ in size. The microagglomerates are separated from coal mineral matter and refuse in a floatation cell, and ' 'ashed and separated from pyrite particles in a 1.jdroseparator. Then microagglomerates are transferred to a low shear mixer where more bridging oil is added and macroagglomerates are enlarged to $0.8 \mathrm{~mm}$ to $3.0 \mathrm{~mm}$ in size. The coal refuse in the floatation and hydroseparator underflow is removed and disposed of.

For coals which are difficult to clean, the microagglomeration process is run in two stages. First stage, as described above, is followed by wet grinding of microagglomerates to reduce the top particle size from $-0.6 \mathrm{~mm}$ ( $-28 \mathrm{mesh}$ ) to $-0.15 \mathrm{~mm}(-100$ mesh). The ground coal is resuspended in water and microagglomerated with an additional amount of bridging oil. The microagglomerates are separated by flotation and then agglomerated in low shear mixer for size enlargement.

The Aglofloat process offers several advantages for the processing of bituminous coals, namely: 1. It removes mineral matter and pyrite, and therefore increases ROM coal quality and heating value. Some medium sulphur coals can be brought into $\mathrm{SO}_{2}$ emission compliance.

2. The process can be used to recover combustible matter from coal preparation plant rejects. When used in this way, it produces a saleable product and reduces the coal preparation plant's waste disposal costs.

The Aglofloat process has several advantages over other coal cleaning and upgrading technologies. Because it is based on differences between the surface properties of coal and mineral matter, it is very efficient for cleaning fine coals. Another advantage of the process is its potential to achieve high pyrite removal, at high combustible recoveries, without the need for expensive solvents and solvent recovery equipment. Also, when compared to multistage floatation, the Aglofloat process offers much higher combustible recoveries (Table 1.1). The Aglofloat is less expensive and generates more environmentally acceptable refuse than chemical cleaning processes.

The main disadvantage of the process is the large amount of oil which must be used in the size enlargement step. Work will continue to find ways to reduce the oil required in the size enlargement step. Process applications that do not require enlargement steps will also be sought.

Table 1.1. Comparison of Aglofloat to other coal desulphurization process.

\begin{tabular}{|c|c|c|c|c|c|c|c|}
\hline & & & & & & & \\
\hline & Coal & $\begin{array}{l}\text { Ash } \\
\% \%\end{array}$ & $\begin{array}{c}\text { Total } \\
\text { sulphur } \\
\%\end{array}$ & $\begin{array}{c}\text { Ash } \\
\%\end{array}$ & $\begin{array}{c}\text { Total } \\
\text { sulphur } \\
\%\end{array}$ & $\begin{array}{c}\text { sulphur } \\
\text { removal } \\
\%\end{array}$ & $\begin{array}{c}\text { recovery } \\
\%\end{array}$ \\
\hline Aglofloat & $\begin{array}{l}\text { Illinois No. } 6 \\
\text { Upper Freepont } \\
\text { Pittsburgh }\end{array}$ & $\begin{array}{l}39.5 \\
12.3 \\
17.7\end{array}$ & $\begin{array}{l}4.19 \\
2.33 \\
4.98\end{array}$ & $\begin{array}{l}6.8 \\
6.2 \\
5.5\end{array}$ & $\begin{array}{l}3.70 \\
1.10 \\
3.24\end{array}$ & $\begin{array}{l}77 \\
93 \\
85\end{array}$ & $\begin{array}{l}89 \\
96 \\
95\end{array}$ \\
\hline $\begin{array}{l}\text { Multistage } \\
\text { Floatation }\end{array}$ & Princo Mino & 13.2 & 3.70 & 5.0 & $\cdot$ & 8.2 & 72 \\
\hline Reverse & $\begin{array}{l}\text { Pittsburgh } \\
\text { Lower Freeport }\end{array}$ & $\begin{array}{l}30.6 \\
31.4\end{array}$ & $\begin{array}{l}1.72 \\
2.65\end{array}$ & $\begin{array}{l}8.7 \\
6.8\end{array}$ & $\begin{array}{l}1.17 \\
0.92\end{array}$ & $\begin{array}{l}76 \\
92\end{array}$ & $\begin{array}{l}92 \\
89\end{array}$ \\
\hline Otsica & $\begin{array}{l}\text { Upper Freeport } \\
\text { Pittsburgh No. } 8\end{array}$ & $\begin{array}{l}17.7 \\
30.2\end{array}$ & $\begin{array}{l}2.66 \\
4.51\end{array}$ & $\begin{array}{l}5.0 \\
6.4\end{array}$ & $\begin{array}{l}1.02 \\
3.41\end{array}$ & $\begin{array}{l}80 \\
57\end{array}$ & $\begin{array}{l}79 \\
94\end{array}$ \\
\hline
\end{tabular}




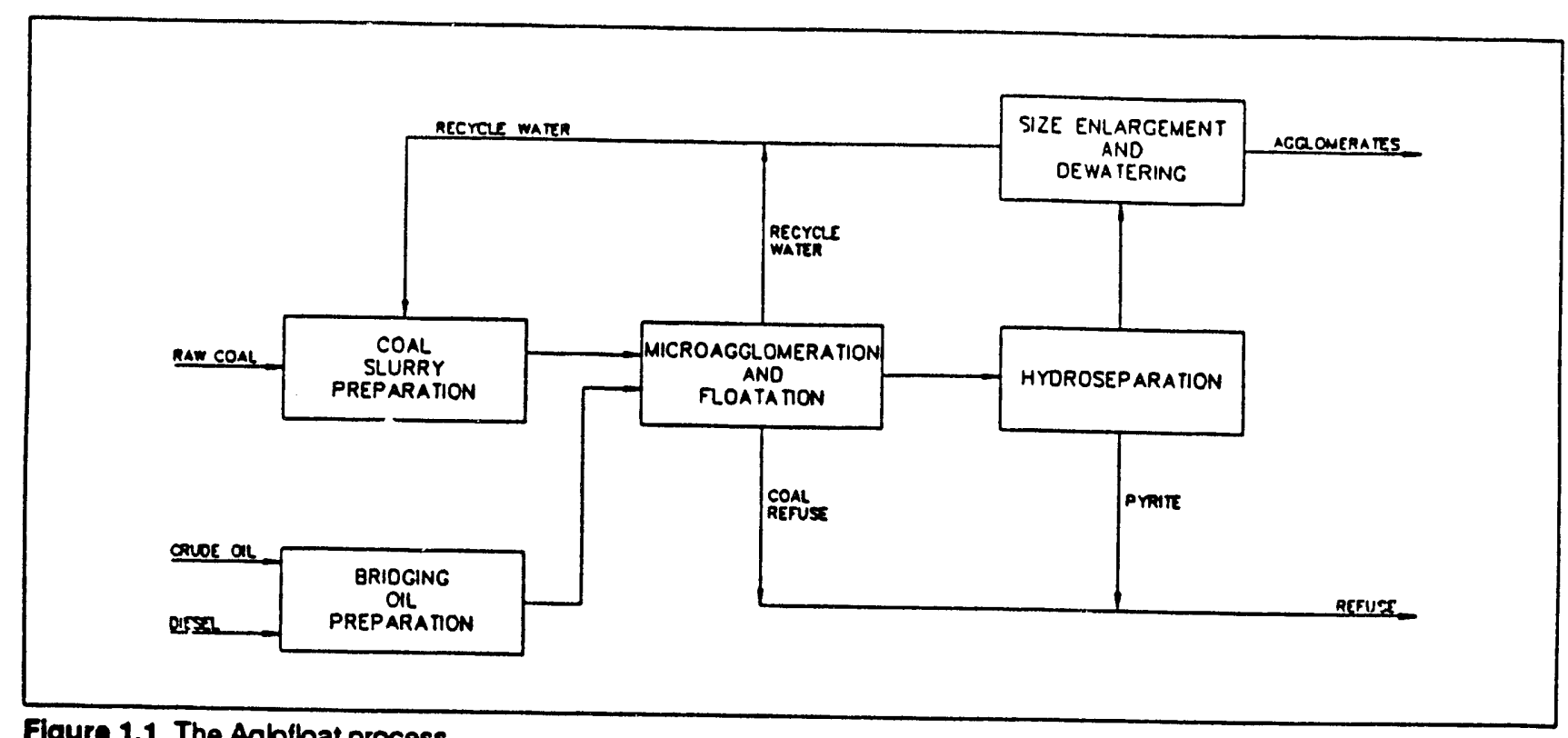

Figure 1.1. The Aglofloat process.

\subsection{Objectives and Scope of the Program}

The overall objective of the Coal Development program was to solve coal utilization problems caused by poor quality coals, which typically have high moisture, ash and sulphur content, through the development of clean coal technologies using coal-oil agglomeration. The general objectives with respect to high-sulphur bituminous coals were the development of technologies which would:

- Remove ash and pyrite from high-sulphur and - mineral matter bituminous coal, thus making these coals more marketable and more acceptable when burned. Their greater acceptability results from the fact that they produce a lower level of sulphur dioxide emissions.

- Recover coal from fines generated in coal preparation plants, thus improving utilization of ROM coals.

- Improve boiler operation and efficiency by supplying a coal product of more uniform quality, and improve the operation of coal handling and pulverization equipment by supplying a fuel that is lower in ash and pyrite.

The specific objectives of the bituminous coal program were to explore and evaluate the application of advarned agglomeration technology for:

- Desulphurization of bituminous coals to sulphur content acceptable within the current EPA SO 2 emission guidelines;
- deashing of bituminous coals to ash content of less than 10 percent; and

- increasing the calorific value of bituminous coals to above 13,000 Btu/lb.

Research during the project focused on establishing the technical and commercial viability of the Aglofloat process. There was a need to solve engineering problems and improve the economics of the process. As well, there was a need to demonstrate that the clean coal product is suitable for use in utility industry.

Testing the commercial polential of the Aglofloat process took two and a half years. Key technical and process economic issues addressed during this time included:

- Process Research Studies: to determine the expected process performance in batch characterization methods for selected leeds, and to obtain process information useful for the design and operation of the Integrated Agglomeration Test Facility (IATF) and Pyrite Removal Unit at ARC.

- Engineering Studles: to determine the key design concerns for the pilot plant and commercial plants, to develop process control strategy, to obtain engineering and operating data required for process evaluation, and to develop design criteria for conceptual design and cost analysis of the Aglofloat process. 
- Economic Studles: to determine the economic feasibility of the process including variance analysis with respect to key economic and process assumptions.

Examples of activities undertaken during the bituminous coal project include: batch and continuous scale agglomeration and separation tests, construction and operation of a 6 tonnes per day pilot plant, and techno-economic assessment of the feasibility of the process. The results of these process development activites are discussed in Sections 2 through 7.

\subsection{Project Organization}

The project organization chart is presented in Figure 1.2 .

Two committees provided direction for the project. These committees were:

1. A Management Committee with overall responsibility for program management, funding and implementation of the Coal Development program.
2. A Technical Committee with overall responsibility for the operation and conduct of the program.

The specific responsibilities of the Management Committee were: to approve the annual budgets and any changes in the scope of the program; to approve the Technical Committee's reports; to establish milestones, schedules, etc.; to approve major expenditures not included in the Annual Budget.

The specitic responsibilities of the Technical Committee were: to oversee program development and achievement of milestones; 10 approve and evaluate manuals prepared by the engineering staff; to oversee development of designs and specifications; to prepare the Annual Budget and periodic reports for submission to the Management Committee.

\subsection{Report Organization}

The results of the ARC/EPRI Coal Processing Development Program are presented in three volumes, each addressing specific applications of advanced agglomeration technology:

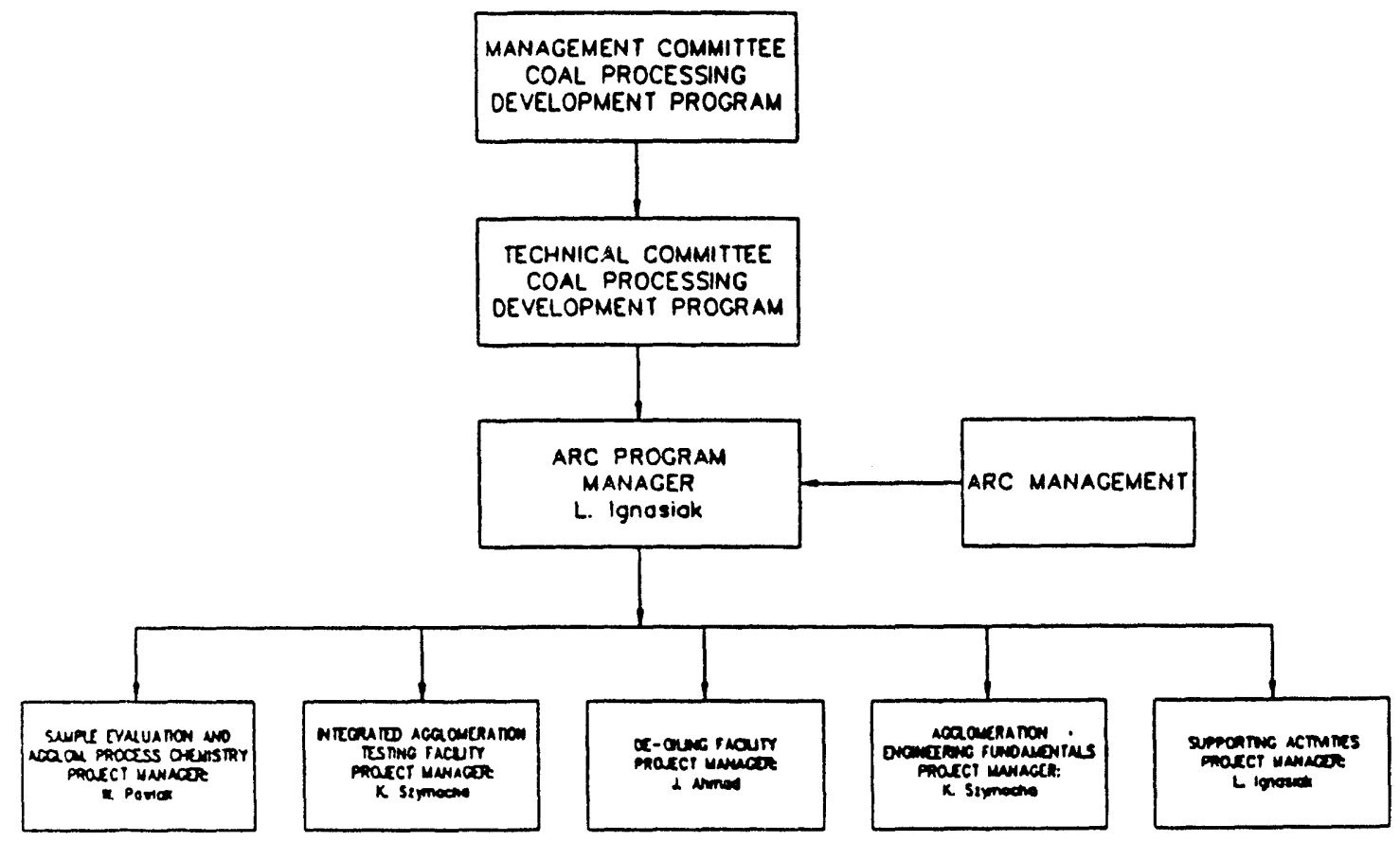

Figure 1.2. Project Organization Chart. 
Volume 1. Upgrading of Low Rank Coals: the Agflotherm Process

Volume 2. Removal of Ash and Pyritic Sulphur from

Bituminous Coals: the Aglofloat Process

Volume 3. Soil Clean-up and Hydrocarbon Waste

Treatment Process: the Clean Soil Process

Each volume of the report is supplemented by an Appendix containing relevant background data and additional information and descriptions of process designs.

This volume of the report presents the results of ARC's laboratory and pilot plant work on the development of improved agglomeration technology for upgrading of bituminous coals. Chapter 2 begins with a description of the coals and oils selected for testing with the Aglofloat process. The chapter includes descriptions of the bench experimental procedures used and the results of process research and optimization work.

In Chapter 3, Volume 2, design studies completed on the agglomeration mechanism are reviewed. These studies focus on fundamentals of the Aglofloat process, application of agglomeration models in process design, and evaluation of critical design issues. The chapter also discusses batch and continuous operations and studies of agglomeration kinetics.
Chapter 4 includes a description of the designi and operation of the Pyrite Removal Unit. It details major equipment included in the unit, the commissioning of the unit and results obtained during operation of the unit.

Chapter 5 describes the experimental results from the Integrated Agglomeration Test Facilities. The chapter starts with a review of major equipment and instrumentation. This is followed by a description of plant commissioning, details of the operating experience and unit improvements.

Chapter 6 briefly reviews the major emissions and waste streams for the Aglofloat process and ine environmental control technology required to operate the process within the EPA emissions guidelines.

The conceptual design and cost analysis of an Aglofloat plant are presented in Chapter 7. The chapter includes process and economic data and assumptions, process area cost estimates, and financial analysis of the plant.

Chapter 8 presents the major conclusions and recommendations relating to the Aglofloat process. The key issues addressed are further improvements of the process economics and efficiency, and reduction of oil use for agglomerates size enlargement. The references quoted in Volume 1 of the report are presented in Chapter 9. 


\section{Bench Scale Characterization of Coals and Oils for the Aglofloat Process}

\subsection{Experimental Procedures}

\subsubsection{Approach}

The batch tests which were performed for the Aglofloat process had three major process research and development objectives:

1. To determine process performance of the Aglofloat process for treatment of the selected coalvoil feedstock combinations.

2. To obtain process research information useful to the design and operation of the Integrated Agglomeration Test Facilities (IATF).

3. To conduct investigations in support of the Aglofloat process including research into the agglomeration and separation mechanisms for processing bituminous coals.

A standard floatation machine equipped with a 2 liter floatation cell was used during the tests. It was felt that experiments of this size would be adequate for all necessary analyses of agglomerates and oils. The tests and equipment selected were also capable of providing process research type information in support of the design and operation of the integrated Agglomeration Test Facilities.

Figure 2.1 illustrates the experimental procedures used in batch-scale characterization of coals and oils. The experiments were performed in several steps. In a typical single-stage Aglofloat process, a known amount of $\infty$ al was mixed with water to make up the required solids concentration. The resulting suspension was agitated for one minute to ensure complete wetting and then a specified amount of bridging liquid (usually 0.5 percent to 5 percent on dry coal) was added. The slurry was agitated up to the moment when phase separation occurred. Thitty to 60 seconds of agitation were usually required. The volume of shumy was then adjusted by adding water to achiove 10 percent solids concentration and coal flocs were separated by simple floatation. The collected coal was resuspended in fresh water, mixed for one minute to release the entrapped mineral matter (pyrite) particles, and separated again. The microagglomerates were dried, weighed and analyzed for moisture, ash, sulphur and caloritic value. The two-stage Aglofloat experiments were a combination of two single-stage processes with interstage wet grinding. Table 2.1. depicts typical test conditions for the Aglofloat batch experiments.

\subsubsection{Equipment}

Equipment used during batch tests included an agglomeration tank, a laboratory floatation machine, and a sieve. Additional equipment and instrumentation was used for sample analyses, product analyses, product handling, etc. A detailed description of the batch agglomeration equipment is provided in Section 2.1. Volume 1 of this report.

Table 21. Aglofleat process: Test conditions.

\begin{tabular}{|c|c|c|}
\hline $\begin{array}{l}\text { Size of coal } \\
\text { particles }\end{array}$ & $\begin{array}{l}\text { Dry grinding: } \\
\text { Wot grinding: }\end{array}$ & $\begin{array}{l}\text { top size } 600 \mu \mathrm{m}, \\
\text { dso } 200 \mu \mathrm{m} \\
\text { top size } 150 \mu \mathrm{m}, \\
\text { dso } 25 \mu \mathrm{m}\end{array}$ \\
\hline $\begin{array}{l}\text { Solids } \\
\text { concentration } \\
\text { (in slury) }\end{array}$ & $\begin{array}{l}\text { Agglomeration: } \\
\text { Froth floatation: }\end{array}$ & $\begin{array}{l}10 \%-25 \% \\
5 \%-12.5 \%\end{array}$ \\
\hline $\begin{array}{l}\text { Bridging inquids } \\
\text { Bridging } \\
\text { liquid conc. }\end{array}$ & \multicolumn{2}{|c|}{$\begin{array}{l}\text { Blends of bitumen and/or hoavy oils } \\
\text { with diesel oil or kerosene }\end{array}$} \\
\hline $\begin{array}{l}\text { Temperature } \\
\text { pH of slumy }\end{array}$ & $\begin{array}{l}\text { Agglomeration: } \\
\text { Froth floatation: } \\
\text { Ambient } \\
\text { Natural }\end{array}$ & $\begin{array}{l}2,100 \mathrm{rmm} \\
1,100 \mathrm{rmm}\end{array}$ \\
\hline
\end{tabular}

\subsubsection{Sample Preparation}

A variety of coal and oil sample combinations were tested to determine their performance in the Aglofloat process. Each of these samples was subjected to the following preparation procedures:

1. The coal samples were air dried, crushed and ground to $-600 \mu \mathrm{m}$ top coal particle size $(-0.6 \mathrm{~mm}$ or -28 mesh) and to a weight average mass median, particle diameter, dso, about $200 \mu \mathrm{m}$.

2. The oil samples were mixed, divided into representative subsamples, and used as crude samples without any emuls fication or dispersion in water.

\subsubsection{Test Methods and Procedures}

Table 2.2 lists the test methods and procedures used to characterize the teedstocks and agglomerate products. In addition to the tests in this table, other specialized tests such as gel permeation chromatography for oil characterization, or surface area measurement for $c 0 a l$, were used when necessary. These tests are described and discussed in the following sections. 


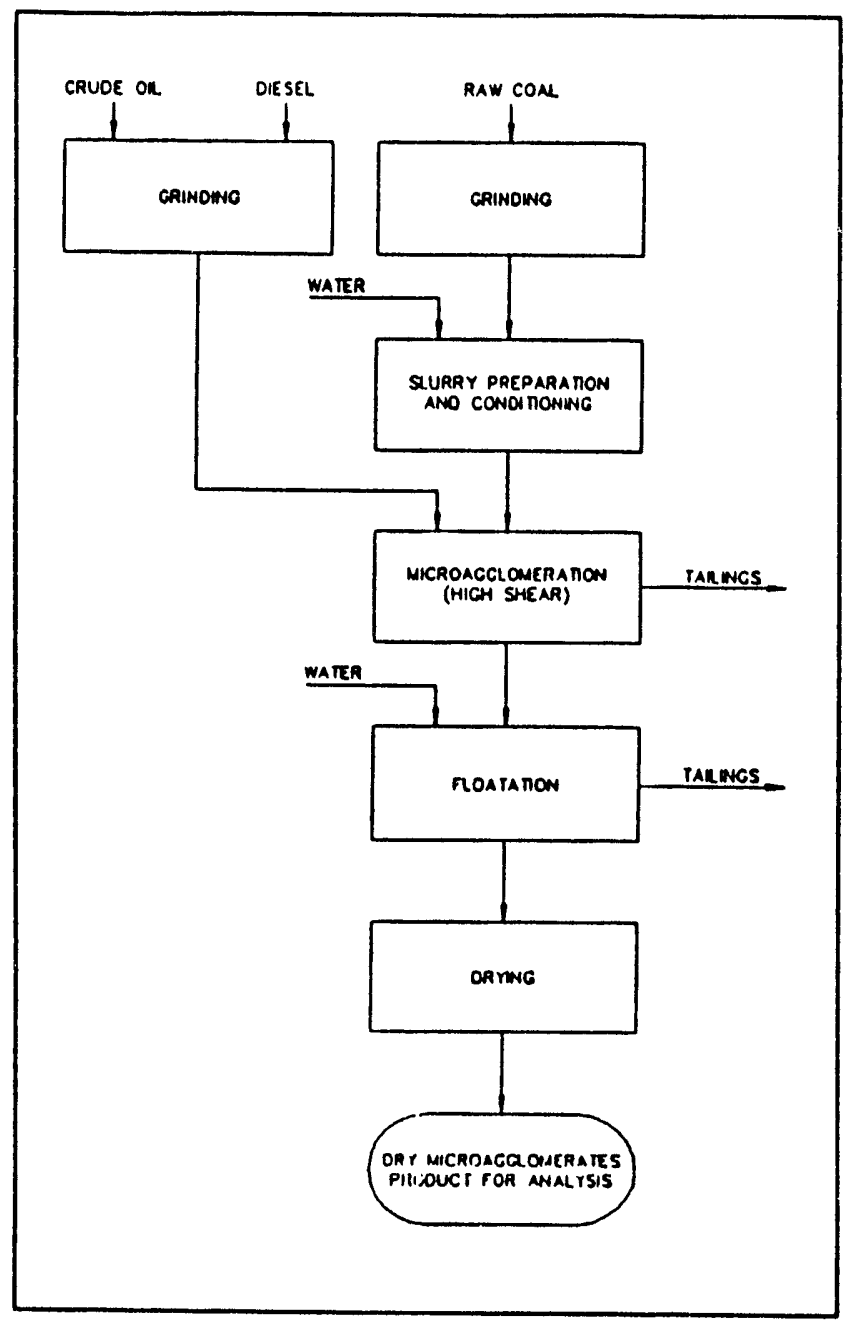

Figure 2.1. Schematic representation of Agblbat batch procedures.

\subsection{Process Research and Optimization}

\subsubsection{Coal Samples Data Base}

Ten bituminous coal samples, six high sulphur bituminous coals from the U.S. and four coal preparation products from Alberta, were submitted for testing under this program. Participating organizations and their selected coals are listed in Table 2.3. The sample size varied from 5 kilograms to 20 tonnes, with the large samples being designated for the pilot plant tests. The samples were nun-ot-mine or washed grab samples including fines and precipitator dust from coal preparation plants.
Table 2.2. Test methods and procedures.

\begin{tabular}{|c|c|c|}
\hline Sample & Test method & Procedure/standard \\
\hline $\begin{array}{l}\text { Coal } \\
\text { agglomerate }\end{array}$ & $\begin{array}{l}\text { Proximate } \\
\text { Ultimate } \\
\text { Total Sulphur } \\
\text { Heating Value } \\
\text { Particlo Size } \\
\text { Capacity Moisture }\end{array}$ & $\begin{array}{l}\text { Fisher Coal Analyzer } \\
\text { ASTM draft stage } \\
\text { Leco CHN-600 } \\
\text { Leco SC-32 } \\
\text { ASTM D } 4239-95 \\
\text { ASTM D 2015 } \\
\text { Granulometer } 723 \\
\text { Laser Light } \\
\text { Diffraction } \\
\text { ASTM D } 1412.85\end{array}$ \\
\hline Oils & $\begin{array}{l}\text { Density } \\
\text { (API gravity) } \\
\text { Viscosity } \\
\text { Simulated } \\
\text { Distillation } \\
\text { Molecular } \\
\text { Weight }\end{array}$ & $\begin{array}{l}\text { PAAR Density Moter } \\
\text { Model DMA } 55 \\
\text { Brookfield Digital } \\
\text { Viscometer } \\
\text { ASTM D2887 } \\
\text { Vapor Pressure } \\
\text { Osmometry Corona } \\
\text { Wescan Molecular } \\
\text { Weight Apparatus }\end{array}$ \\
\hline
\end{tabular}

Table 2.3. "Participating" coals: The Aglofloat process.

\begin{tabular}{|c|c|}
\hline Organization & Sample name and descriptlon \\
\hline $\begin{array}{l}\text { U.S. Dept. } \\
\text { of Energy }\end{array}$ & $\begin{array}{l}\text { Upper Freeport - bituminous coal } \\
\text { Illinois No. } 6 \text { - bituminous coal } \\
\text { Pittsburgh Seam - bituminous coal }\end{array}$ \\
\hline $\begin{array}{l}\text { Ohio Ontario } \\
\text { Cloan Fuols }\end{array}$ & Ohib Sample - bituminous coal \\
\hline $\begin{array}{l}\text { Illinois State } \\
\text { Geological } \\
\text { Survoy }\end{array}$ & $\begin{array}{l}\text { Illinois No. } 6 \text { - bituminous coal (ROM) } \\
\text { Indiana V - bituminous } \infty \text { al (washod) }\end{array}$ \\
\hline $\begin{array}{l}\text { Obed Mountain } \\
\text { Coal Company }\end{array}$ & $\begin{array}{l}\text { Obed - bituminous coal (precipitator dust) } \\
\text { Obed - bituminous coal (washed) }\end{array}$ \\
\hline $\begin{array}{l}\text { Ontario } \\
\text { Hydro }\end{array}$ & $\begin{array}{l}\text { Byron Creok - bituminous coal } \\
\text { (fines - fitercake) } \\
\text { Byron Creek - bituminous coal reject }\end{array}$ \\
\hline
\end{tabular}

The range of properties for the samples submitted was as follows:

Moisture, \% as received

$8.5-24.5$

Ash, \%

$9.2 \cdot 34.8$

Sulphur, \% total

$0.30-4.98$

Sulphur, \% pyritic

$<1.3-3.4$

Heating Value, GJ/

$19.4 \cdot 31.5$

Heating Value, Btu/b

$8,350-13,560$

A detailed analysis of the samples submitted is given in Appendix 2. 


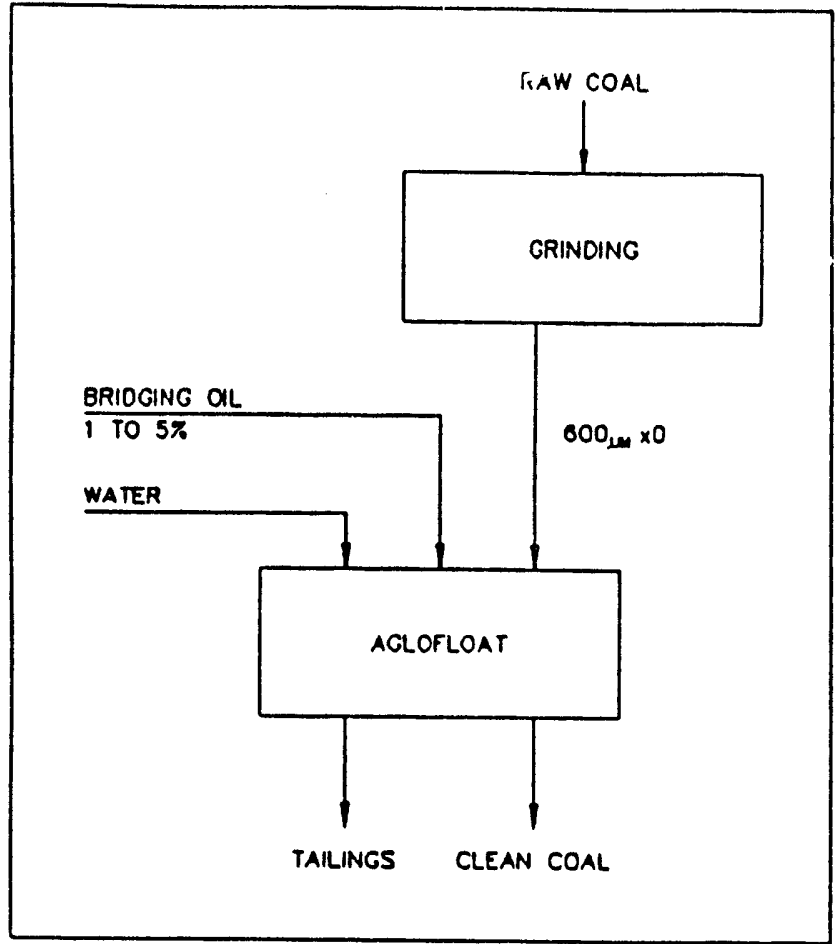

Figure 2.2. Single-stage Aglofloat process.

The following sections describe examples of the effects of different process variables and feed properties on cleaning of the "participating" coals. These examples are illustrative only and are not intended to provide proof for the trends discussed. Such proof and more detailed support for the conclusions drawn were reported previously in ARC's technical papers documenting several years of research by ARC on agglomeration of bituminous and subbituminous coals.

\subsubsection{Single- and Two-Stage Processing}

Two procedures were followed during characterization of the coal samples in the Aglofloat process:

1. A single-stage process where grinding coal to top size of $-600 \mu \mathrm{m}$ was sufficient for liberation of pyrite and mineral matter from the coal organic material (Figure 2.2).

2. A two-stage process with a regrinding of the product coal from the single-stage to top coal size of $150 \mu \mathrm{m}$ and $d_{s o} \sim 25 \mu \mathrm{m}$ and reagglomeration of the coal in order to achieve high pyrite and mineral matter liberation in the process (Figure 2.3).

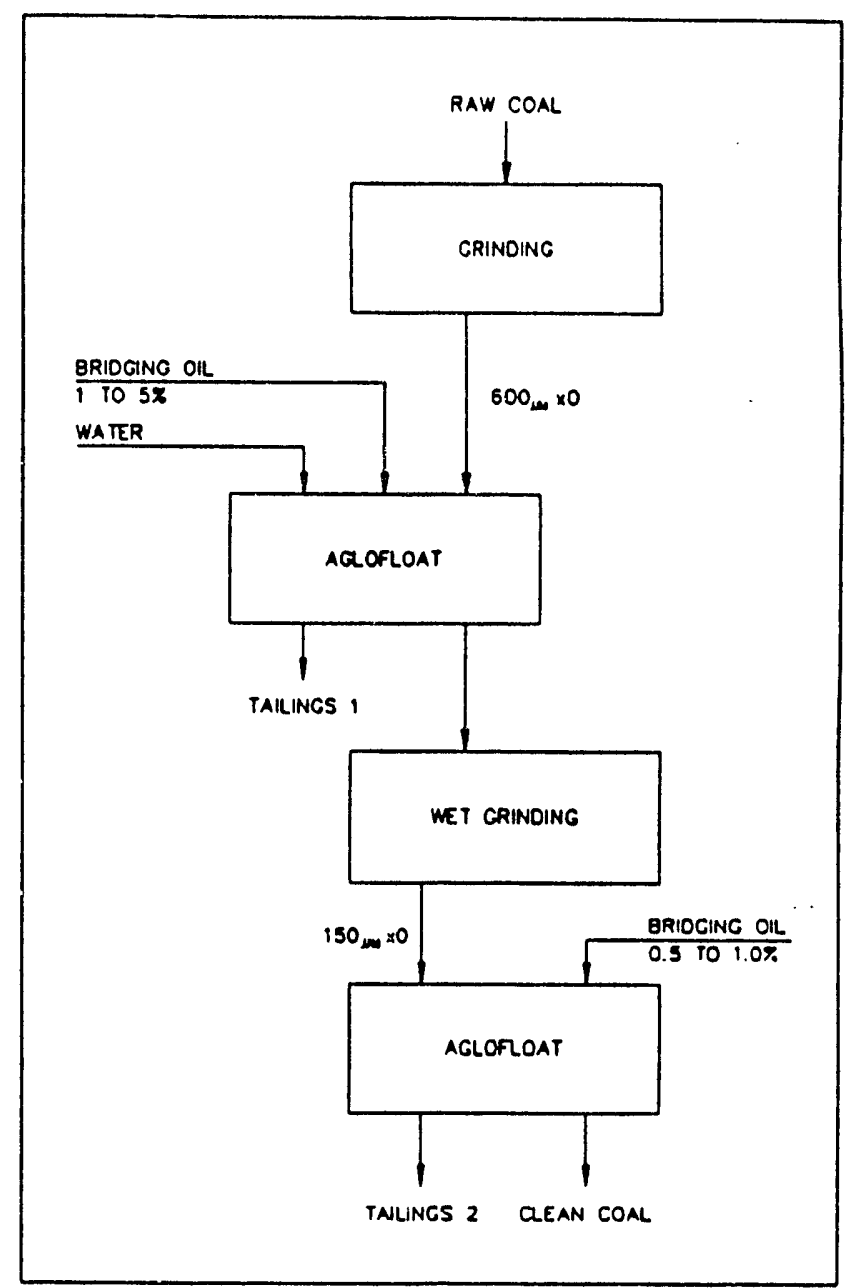

Flgure 2.3. Two-stage Aglotbat process with interstage wet grinding.

The results of tesis which compared single- and two-stage processes for the selected U.S. coals are depicted in Figures 2.4 to 2.7. The key conclusions which may be drawn from these tests are:

- Ash reduction increased by 2 to 4 percent (coal basis) by going from single- to two-stage processing.

- Total sulphur reduction increased by 0.5 to 1 percent (coal basis) when using the two-stage process instead of the single-stage process.

- The removal of inorganic sulphur increased from 50-55 percent to $60-80$ percent by using the two-stage process.

- The recovery of combustibles decreased from 93-98 percent to 89-96 percent through the use of the two-stage process. 

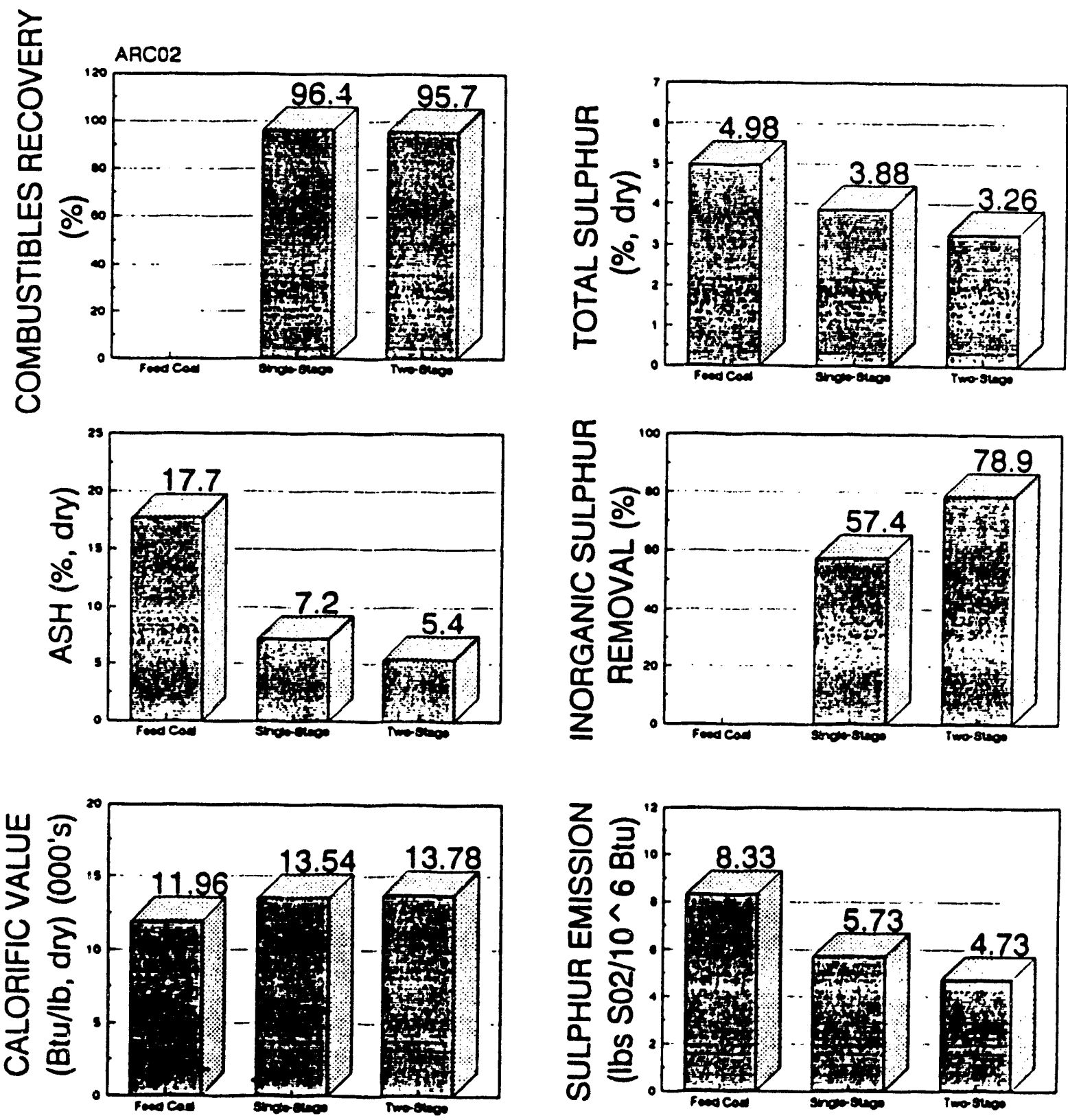

Figure 2.4. Cleaning of Pittsburgh seam coal by Aglofbat process.

The choice of a single- or two-stage process for processing of a selected coal sample would, therefore, depend on the level of ash and pyrite in the sample and the cleaning level desired. High ash. high pyrite samples containing particles of inorganic materials with a wide size distribution would require a two-stage process, whereas coals with large size mineral matter particles or low ash and pyrite content could be cleaned in a single-stage process.

\subsubsection{Effect of Sample Preparation on Ash and Pyrite Rejection}

A series of tests was performed to further evaluate the single- and two-stage processes. Specifically, 


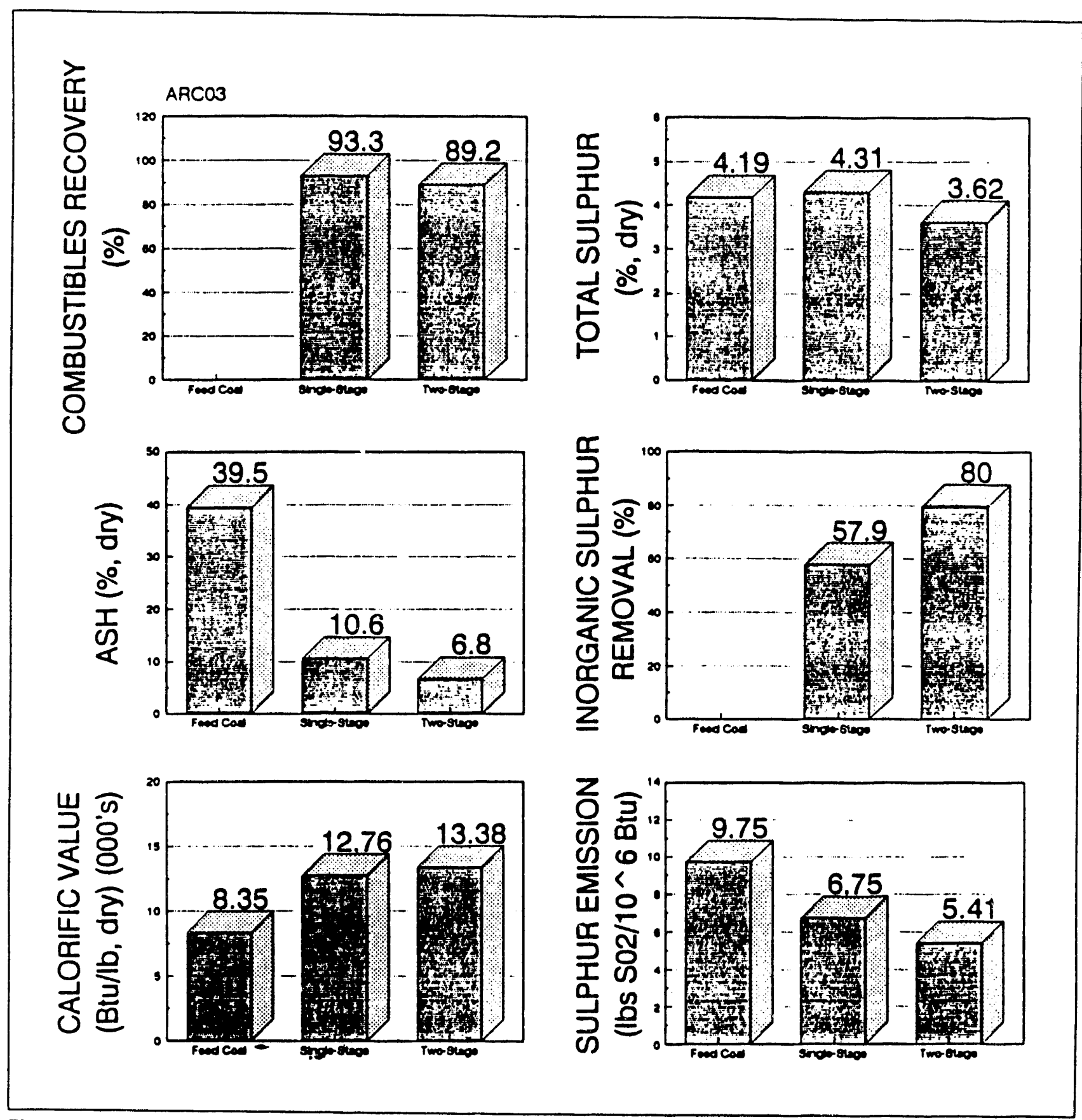

Flgure 2.5. Cleaning of llinois no. 6 coal by Aglofbat process.

tests to assess the effects of different degrees and types of grinding, to compare single-stage wet grinding to the two-stage Aglofloat process, and to compare single- and two-stage processing to washability tests were performed. The washability test is commonly considered a measure of the ease with which mineral matter can be separated from coal.
Comparison of single-stage wet grinding to twostage processing using the same amount of bridging oil (1 percent) is depicted in Table 2.4. It is shown, again, that a second agglomeration and grinding step reduced the ash content in the product and in. creased the removal of inorganic sulphur. 


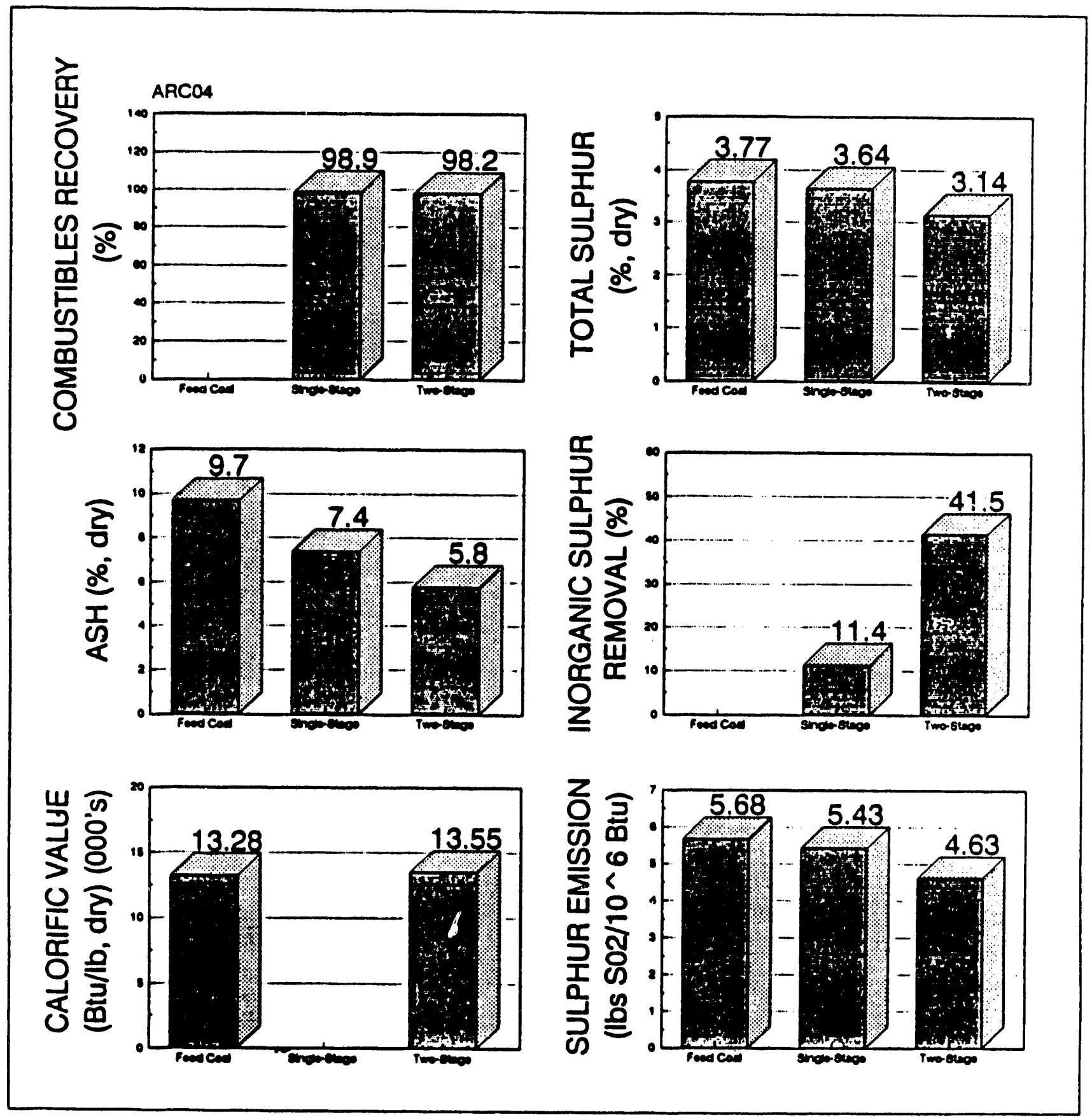

Figure 2.6. Cleaning of Indiana $V$ coal by Aglofloat process.

A comparison of single-stage agglomeration to the float and sink test is presented in Table 2.5. The washability tests were performed using a modifïgd float-sink procecture described by Franzidis and Harris (1986). The results suggest that buth float-sink tests and single-stage agglomeration can be used as an indicator of the ease with which mineral matter can be separated from a sample of coal. Float-sink at a density of $1.6 \mathrm{~g} / \mathrm{cm}^{3}$ seems to yield coal recovery and ash content similar to the single-stage Aglofloat tests. 


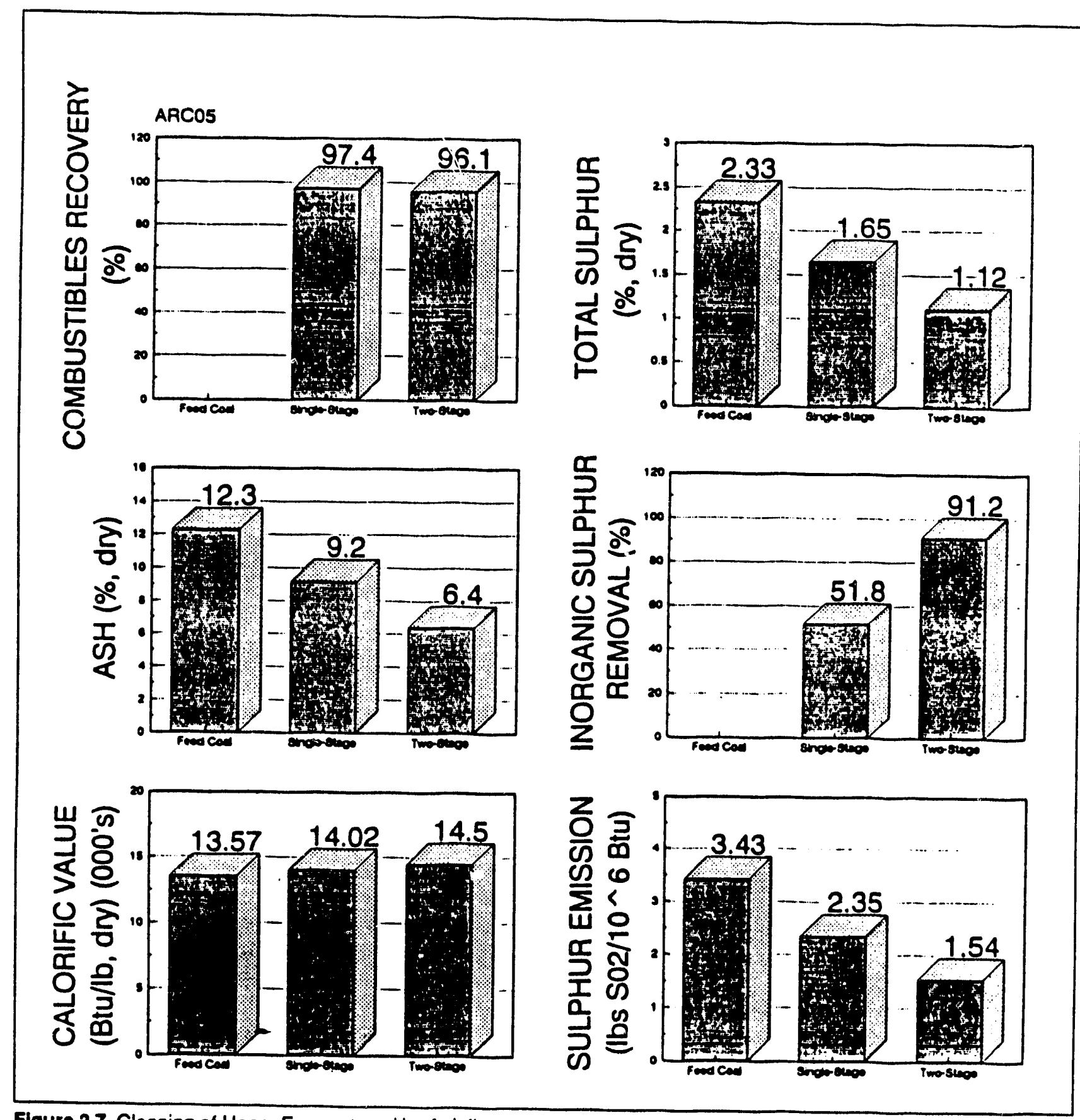

Figure 2.7. Cleaning of Upper Freeport coal by Aglofbat process.

\subsubsection{Effect of Coal and Oil Concentration}

Tables 2.6 to 2.8 depict the effect of coal and oil concentration on the ash and sulphur content of the agglomerate products and on combustibles recovery. The key effects presented are:

- An easy, good separation was obtained for a wide range of coal concentrations - 10 to 25 percent - with a slight increase in ash content observed for high solid loading due to an entrapment of mineral matter in agglomerates (Table 2.6).

- A consistent low ash and sulphur content in the product was obtained over a range of bridging oil addition ( 0.6 to 12 percent) with slightly higher pyrite and ash content observed at high oil 
Table 2.4. Effect of grinding on Aglofloat process performance.

\begin{tabular}{|c|c|c|c|c|c|}
\hline $\begin{array}{l}\text { Experl- } \\
\text { mental } \\
\text { proce- } \\
\text { dure }\end{array}$ & $\begin{array}{l}\text { Brldging } \\
\text { llquild } \\
\text { addition" } \\
(\%)\end{array}$ & $\begin{array}{c}\text { Combust. } \\
\text { recovery } \\
(\%)\end{array}$ & $\begin{array}{l}\text { Ash } \\
\text { (\%) }\end{array}$ & $\begin{array}{l}\text { Total } \\
\text { sulphur } \\
\text { (\%) }\end{array}$ & $\begin{array}{c}\text { Inorganic } \\
\text { sulphur } \\
\text { removal } \\
(\%)\end{array}$ \\
\hline \multicolumn{2}{|c|}{ Parent Coab - } & - & 14.3 & 4.27 & - \\
\hline $\begin{array}{l}\text { Wet grinding } \\
\text { followed by } \\
\text { single-stage }\end{array}$ & $\begin{array}{ll}\mathrm{ng} & \\
y & 1.0 \\
90 & \end{array}$ & 99.8 & 7.7 & 3.04 & 70.7 \\
\hline & & & & & \\
\hline
\end{tabular}

a: Mixture of heavy oil and clesel oil in ratio 2:3.

b: Illinois No. 6; Forms of sulphur. $1.98 \%$ pyritic, $0.15 \%$ sulfatic and $2.13 \%$ organic.

Table 25. Comparison of float-sink and Aglofloat testse.

\begin{tabular}{llc}
\hline & Viold & Ash \\
\hline Float-Sink & & \\
$1.4 \mathrm{~g}^{3} \mathrm{~cm}^{3}$ & $38.6 \%$ & $-6.7 \%$ \\
$1.6 \mathrm{~g}^{3} \mathrm{~cm}^{3}$ & $58.8 \%$ & $-12.5 \%$ \\
Single-Stage Aglofloat & $63.0 \%$ & $10-11 \%$ \\
\hline
\end{tabular}

a: Pertormed with Illinois No. 6, 39.5\% ash.

Top size $600 \mu \mathrm{m}, 050-240 \mu \mathrm{m}$.

Table 2.6. Effect of solids concentration on Aglofloat processa performanco.

\begin{tabular}{|c|c|c|c|c|c|}
\hline \multicolumn{5}{|c|}{ Sollds Concentration } & \multirow[b]{2}{*}{$\begin{array}{l}\text { Total } \\
\text { sulphur } \\
\text { romoval } \\
\text { (\%) }\end{array}$} \\
\hline $\begin{array}{l}\text { Micro- } \\
\text { agglom } \\
\text { oration }\end{array}$ & Soparation & $\begin{array}{l}\text { Combust. } \\
\text { recovery } \\
(\%)\end{array}$ & $\begin{array}{l}\text { Ash } \\
\text { (\%) }\end{array}$ & $\begin{array}{l}\text { Total } \\
\text { sulphur } \\
\text { (\%) }\end{array}$ & \\
\hline \multicolumn{2}{|c|}{ Parent Coap } & & 14.3 & 4.27 & \\
\hline $\begin{array}{l}10 \\
15 \\
20 \\
25\end{array}$ & $\begin{array}{r}5.0 \\
7.5 \\
10.0 \\
12.5\end{array}$ & $\begin{array}{l}99.4 \\
99.7 \\
99.3\end{array}$ & $\begin{array}{l}9.4 \\
9.7 \\
9.7\end{array}$ & $\begin{array}{l}3.03 \\
3.07 \\
3.14 \\
3.14\end{array}$ & \\
\hline
\end{tabular}

Note: All values on dry bain.

a: Single-stage process; $0.6 \%$ bridging liquid addition.

b: Illinois No. 5. Forms of sulphur. 1. $86 \%$ pyritic, $0.15 \%$ sulfatic

and $2.13 \%$ organic.

addition, again because of entrapment of the ash in agglomerates (Table 2.7).

- Consistent, high combustibles recovery was obtained at a bridging oil concentration above 0.5 percent. However, for concentrations less than 0.5 percent, the percentage of combustibles recovered decreased slightly while the content of ash and sulphur in the product remained the same, within the analytical error (Table 2.8).
Table 2.7. Effect of bridging liquid addition on Aglofloat process ${ }^{a}$ performance.

\begin{tabular}{lcccc}
\hline $\begin{array}{l}\text { Brldging } \\
\text { liquidb } \\
\text { addition } \\
(\%)\end{array}$ & $\begin{array}{c}\text { Combustibles } \\
\text { recovery } \\
(\%)\end{array}$ & $\begin{array}{c}\text { Ash } \\
(\%)\end{array}$ & $\begin{array}{c}\text { Total } \\
\text { sulphur } \\
(\%)\end{array}$ & $\begin{array}{c}\text { Total } \\
\text { sulphur } \\
\text { romoval } \\
(\%)\end{array}$ \\
\hline Parent Coak & - & 14.3 & 4.27 & - \\
0.6 & 98.9 & 8.7 & 3.04 & 33.2 \\
4.0 & 99.4 & 8.7 & 3.04 & 33.2 \\
6.0 & 99.6 & 8.7 & 3.05 & 32.5 \\
8.5 & 99.9 & 8.7 & 3.11 & 30.6 \\
12.0 & 99.9 & 8.9 & 3.20 & 28.3 \\
\hline
\end{tabular}

Note: All values on dry basis.

a: Singlo-stage procoss; b: Bitumen + diesel in ratio 2:3; c: Illinois No. 6, Forms of sulphur: $1.98 \%$ pyritic, $0.15 \%$ sulfatic and $2.13 \%$ organic.

Table 2.8. Effect of bridging liquid addition on Aglofloat processa portormanco.

\begin{tabular}{lcccc}
\hline $\begin{array}{l}\text { Bridging } \\
\text { llquid } \\
\text { adddtionb } \\
(\%)\end{array}$ & $\begin{array}{c}\text { Combustibles } \\
\text { recovery } \\
(\%)\end{array}$ & $\begin{array}{c}\text { Ash } \\
(\%)\end{array}$ & $\begin{array}{c}\text { Total } \\
\text { sulphur } \\
(\%)\end{array}$ & $\begin{array}{c}\text { Inorganle } \\
\text { sulphur } \\
\text { romoval } \\
(\%)\end{array}$ \\
\hline $\begin{array}{l}\text { Parent Coak } \\
1.0\end{array}$ & $9 \overline{5}$ & 14.3 & 4.27 & - \\
$\begin{array}{c}(0.5+0.5) d \\
0.6\end{array}$ & 98.5 & 6.4 & 2.84 & 76.3 \\
$\begin{array}{c}0.5+0.1) d \\
0.3\end{array}$ & 98.1 & 6.6 & 2.91 & 73.3 \\
$(0.2+0.1) d$ & 97.5 & 6.7 & 2.86 & 75.6 \\
\hline
\end{tabular}

a: Two-stage; b: Mixture of heavy oil and diesel oil in ration 2:3; c: Illinois No. 6; forms of sulphur. $1.98 \%$ pyritic, 0.15 sulfatic and $2.13 \%$ organic; d: Oil addition in each stage

It should be noted, that the minimum oil addition required varied depending on coal properties. For example, with Byron Creek fines, the Aglofloat process required 5 percent of bridging oil for a 95 percent combustibles recovery; for high sulphur U.S. coals, 1 percent of bridging oil was sufficient to achieve high recovery. Typically, combustibles recovery of about 95 percent was achieved with 0.5 percent of bridging oil.

\subsubsection{Effect of Oll Properties and Additives}

Table 2.9 depicts results of single- and two-stage processing for different bridging oil compositions (heavy oil or bitumervdiesel 1:1 to 2:3). The results suggest that good combustibles recovery and significant reduction of ash and sulphur can be obtained with a wide range of bridging oil properties. However, as the content of the light oil in the bridg. 
Table 2.9. Effect of bridging liquid composition on Aglofloat process performance.

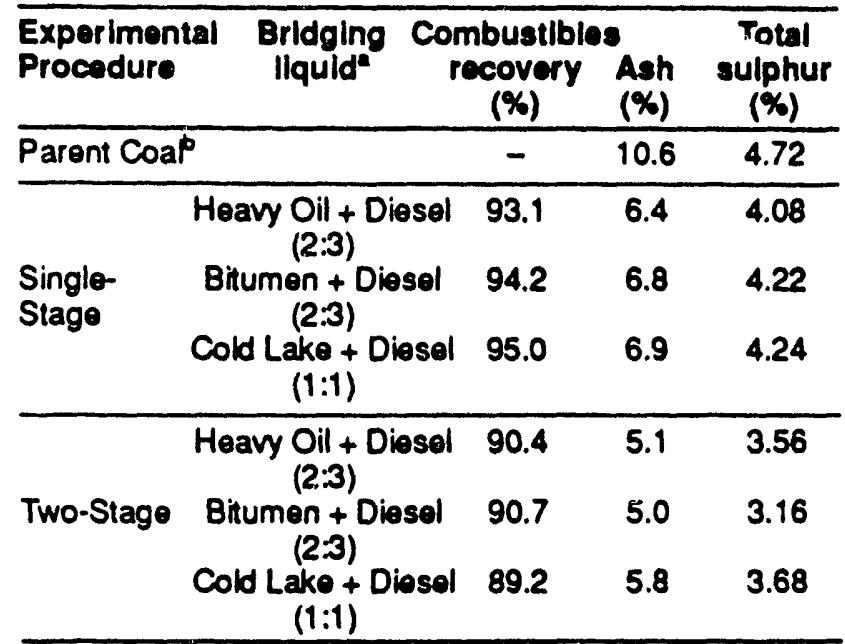

a: Oil addition: $0.6 \%$ singlo-stage and $1.1 \%$ mo-stape.

b: Chio coal; Forms of sulphur: $2.92 \%$ pyritic, $0.26 \%$ sulfatic and $1.51 \%$ organic.

Table 2.10. Effect of bridging liquid composition on Aglofbat process pertormances.

\begin{tabular}{lcccc}
\hline $\begin{array}{l}\text { Bridging } \\
\text { llquldb } \\
\text { compostion }\end{array}$ & $\begin{array}{c}\text { Combustibles } \\
\text { recovery } \\
(\%)\end{array}$ & $\begin{array}{c}\text { Ash } \\
(\%)\end{array}$ & $\begin{array}{c}\text { Total } \\
\text { sulphur } \\
(\%)\end{array}$ & $\begin{array}{c}\text { Tallings } \\
\text { ash } \\
(\%)\end{array}$ \\
\hline Parent Coak & & 9.2 & 4.72 & - \\
$50 \%-50 \%$ & 94.5 & 7.2 & 4.52 & 53.1 \\
$55 \%-45 \%$ & 95.7 & 7.0 & 4.56 & 50.6 \\
$60 \%-40 \%$ & 77.2 & 5.8 & 3.83 & 20.0 \\
$65 \%-35 \%$ & 63.7 & 5.4 & 3.72 & 16.0 \\
$70 \%-30 \%$ & 33.8 & 4.5 & 3.39 & 11.7 \\
\hline
\end{tabular}

a: Singl/s-stage; $0.6 \%$ of bridging liguid addition.

$b$ : Mixtare of Cold Lake botwm and diesel oil.

c: Ohici, coal.

ing oil was decreased, the pertormance of the Aglofloat also decreased (Table 2.9 to 2.11).

The poor Agbofloat pertormance, at low diesel oil concentrations in bridging oil, was significantly improved by the addition of selected surfactants (i.e., polydimethyl siloxan) suggesting that poor coal recovery at diesel concentrations of 50 percent or less is due to the bridging oil's lesser attinity to coal. The role of the surfactants would be, therefore, to change the charges on the coal surface or to improve emulsification of the bridging oil by changing charges on oil droplets. Both hypothesis are plausible and should be further studied.
Table 2.11. Effect of bridging liquid composition on Aglofloat process pertormancea.

\begin{tabular}{lcccc}
\hline $\begin{array}{l}\text { Bridging } \\
\text { llquld } \\
\text { composition }\end{array}$ & Surfactant & \multicolumn{3}{c}{ Combustiblosed Coal } \\
recovery & Ash & $\begin{array}{c}\text { Total } \\
\text { sulphur } \\
(\%)\end{array}$ & $\begin{array}{c}(\%) \\
(\%)\end{array}$ \\
\hline Parent Coaf & & - & 9.2 & 4.72 \\
$50 \%-50 \%$ & - & 94.5 & 7.2 & 4.52 \\
$70 \%-30 \%$ & - & 33.8 & 4.5 & 3.39 \\
$50 \%-50 \%$ & + & 91.3 & 5.7 & 3.85 \\
$70 \%-30 \%$ & + & 90.1 & 5.4 & 3.88 \\
\hline
\end{tabular}

a: Single-stage; $0.6 \%$ of bridging liquid addition; b: Mixture of Cold Lake bottom and diesel oil; c: Ohio coal.

Tablo 2.12. Beneficiation of Byron Creek fines by Aglofbat procoss.

\begin{tabular}{|c|c|c|c|c|c|}
\hline \multicolumn{3}{|c|}{ 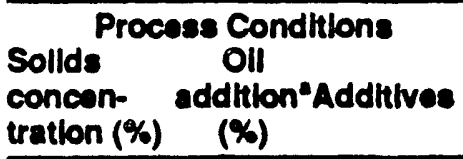 } & \multicolumn{3}{|c|}{$\begin{array}{l}\text { Combustlbles } \\
\text { Yold Recovery Ash } \\
\text { (\%) } \quad(\%) \quad \text { (\%) }\end{array}$} \\
\hline Initial Feed & & & - & - & 21.9 \\
\hline $\begin{array}{l}10 \\
10 \\
25 \\
25\end{array}$ & $\begin{array}{l}0.6 \\
0.6 \\
0.6 \\
5.0\end{array}$ & $\begin{array}{l}- \\
+ \\
+ \\
+\end{array}$ & $\begin{array}{l}77.0 \\
84.8 \\
85.4 \\
90.0\end{array}$ & $\begin{array}{l}86.2 \\
94.0 \\
93.9 \\
95.8\end{array}$ & $\begin{array}{l}12.5 \\
13.4 \\
14.0 \\
15.8\end{array}$ \\
\hline
\end{tabular}

Nolo: All values on dy basis.

a: Brooks oil.

\subsubsection{Treatment of Westem Canadian Coals}

A series of separate tests were conducted for beneficiation of western Canadian coals, including coal fines reject and precipitator dust from coal preparation plants. In general, use of the Aglofloat procedures and bridging oil formulation developed for the U.S. coals gave poor combustibles recovery and ash reduction (Tables 2.12 and 2.13). Only after the formulation of special bridging oils and the addition of surfactants, were the results with western Canadian coals comparable to those with U.S. coals.

\section{Byron Creek Fines and Reject}

Tables 2.12 and 2.13 show that for coal concentration of 25 percent, high performance of the Agthotherm process (combustibles recovery $>90$ percent, etc.) can be obtained only with high bridging oil concentrations and the addition of surtactants.

Both Brooks oil and Cold Lake bitumen gave high combustibles recovery and large ash reduction for a bridging oil concentration of 5 percent, dry coal basis. 
Table 2.13. Beneficiation of Byron Creek fines by Aglofloat process.

\begin{tabular}{|c|c|c|c|c|c|}
\hline $\begin{array}{l}\quad \text { Proce } \\
\text { Solids } \\
\text { Concen- } \\
\text { iration }(\%)\end{array}$ & $\begin{array}{l}\text { ess Condit } \\
\text { Oll } \\
\text { addltlon"A } \\
(\%)\end{array}$ & $\begin{array}{l}\text { Itlons } \\
\text { Additives }\end{array}$ & \multicolumn{3}{|c|}{ Combustlbles } \\
\hline Initial Feed & & & - & - & 21.9 \\
\hline $\begin{array}{l}10 \\
10 \\
25 \\
25 \\
25\end{array}$ & $\begin{array}{l}0.6 \\
0.6 \\
0.6 \\
2.0 \\
5.0\end{array}$ & $\begin{array}{l}- \\
+ \\
+ \\
+ \\
+\end{array}$ & $\begin{array}{l}71.2 \\
83.1 \\
80.4 \\
84.4 \\
86.7\end{array}$ & $\begin{array}{l}79.5 \\
92.5 \\
89.5 \\
93.0 \\
94.2\end{array}$ & $\begin{array}{l}12.7 \\
13.1 \\
13.0 \\
13.5 \\
14.1\end{array}$ \\
\hline
\end{tabular}

Note: All values on dy basis.

a: Cold Lake bitur an blend.

Table 2.14. isecovery of combustible material from Byron Creek fines by Aglofloat processa.

\begin{tabular}{lccc}
\hline $\begin{array}{l}\text { Oll } \\
\text { additionb } \\
(\%)\end{array}$ & $\begin{array}{c}\text { Ybld } \\
(\%)\end{array}$ & $\begin{array}{c}\text { Combustlbles } \\
\text { Recovery } \\
(\%)\end{array}$ & $\begin{array}{c}\text { Ash } \\
(\%)\end{array}$ \\
\hline Initial Feed & - & - & 21.9 \\
\hline 0.25 & 62.6 & 70.3 & 12.3 \\
0.30 & 72.7 & 80.6 & 13.3 \\
0.60 & 80.4 & 89.5 & 13.0 \\
2.00 & 84.4 & 93.0 & 13.5 \\
5.00 & 86.7 & 94.2 & 14.1 \\
\hline
\end{tabular}

Note: All values on dry basis.

a: Singlo-stage with surtactant addition:

b: Cold Lake bitumen blend.

Table 2.14 depicts the effect of the addition of bridging oil on recovery of combustble materials using the single-stage Aglofloat process with surfactant addition. As the bridging oil concentration approached 2 percent or more, high combustibles recoveries were observed. However, the final product also had increased mineral matter content. As shown in Table 2.15, the type of bridging oil did not make a significan difference to the process performance or product yield.

Table 2.16 compares the results of the two-stage Aglofloat process to procedures which use a combination of wet grinding, Aglofloat and agglomeration with high oil concentration (20 percent). The latter procedures were intended to test whether further grinding of fines would improve the ash rejection. The results show that no signiticant improvement was obtained. The lower results for the Aglofloat plus agglomeration process configuration were primarily due to the dilution effect of oil.
Table 2.15. Beneficiation of Byron Creek fines by Aglofloat process.

\begin{tabular}{lccc}
\hline $\begin{array}{l}\text { Bridging } \\
\text { Oll } \\
(\%)\end{array}$ & $\begin{array}{c}\text { Sollds } \\
\text { concentration } \\
(\%)\end{array}$ & $\begin{array}{c}\text { Combustibles } \\
\text { Rocovery } \\
(\%)\end{array}$ & $\begin{array}{c}\text { Ash } \\
(\%)\end{array}$ \\
\hline Initial Foed & - & - & 21.9 \\
\hline $\begin{array}{l}\text { Cold Lake } \\
\text { bitumen blend }\end{array}$ & 10 & 92.5 & 13.1 \\
\hline & 25 & 89.5 & 13.0 \\
Brooks oil & 10 & 94.0 & 13.4 \\
& 25 & 93.9 & 14.0 \\
\hline
\end{tabular}

Note: All values on dry basis.

a: Oil addition $0.6 \%$ on dry foed.

Table 2.16. Beneficiation of Byron Creek fines - effect of additional grinding on deashing.

\begin{tabular}{lcccc}
\hline $\begin{array}{l}\text { Experimental } \\
\text { Procedure }\end{array}$ & $\begin{array}{c}\text { Oll } \\
\text { Addtlions } \\
(\%)\end{array}$ & $\begin{array}{c}\text { Ylold } \\
(\%)\end{array}$ & $\begin{array}{c}\text { Combustibies } \\
\text { Recovery } \\
(\%)\end{array}$ & $\begin{array}{c}\text { Ash } \\
(\%)\end{array}$ \\
\hline Initial Feod & & - & - & 21.9 \\
\hline $\begin{array}{l}\text { Two-Stage } \\
\text { Aglofloat }\end{array}$ & $2+2^{b}$ & 86.4 & 94.7 & 13.5 \\
\hline $\begin{array}{l}\text { Wet grinding } \\
\text { followed } \\
\text { by Aglofloat }\end{array}$ & 2 & 87.6 & 94.6 & 13.6 \\
$\begin{array}{l}\text { Wet grinding } \\
\text { followed by } \\
\text { Agloflbat and } \\
\text { Agglomeration }\end{array}$ & $2+200$ & 82.7 & 91.0 & 10.1 \\
\hline
\end{tabular}

Noto: All values on dy basis.

a: Brooks oil; b: Oil addition in each stage.

Table 2.17 depicts the effect of the type and amount of bridging oil, with and without additives, on the recovery and ash content of combustible materials from Byron Reject, using the single-stage Aglofloat process. Observations were similar to those for Byron fines (Table 2.14); as the bridging oil concentration increased, combustibles recovery and product ash increased. The type of oil seemed to have some effect on both product yield and combustibles recovery, as Brooks oil resulted in higher recoveries than did Esso Oil-bitumen blend.

Table 2.18 shows the effect of product yield and combustibles recovery on product ash content. As expected, higher product yield resulted in higher combustibles recovery and somewhat higher ash comtent of agglomerates. 
Table 2.17. Beneficiation of Byron Creok reject by single-stage Aglofloat process.

\begin{tabular}{|c|c|c|c|c|c|}
\hline \multicolumn{3}{|c|}{$\begin{array}{l}\text { Bridging Ciquid } \\
\text { Type Addtion Additives } \\
\text { (\%) }\end{array}$} & \multicolumn{2}{|c|}{ Combustibles } & $\begin{array}{l}\text { Ash } \\
(\%)\end{array}$ \\
\hline Initial Sam & nplo & & - & - & 47.1 \\
\hline Brooks & $\begin{array}{l}0.6 \\
0.6 \\
1.0 \\
5.0\end{array}$ & $\begin{array}{l}- \\
+ \\
+ \\
+\end{array}$ & $\begin{array}{l}45.2 \\
55.5 \\
57.5 \\
74.3\end{array}$ & $\begin{array}{l}62.8 \\
76.3 \\
82.6 \\
96.7\end{array}$ & $\begin{array}{l}26.9 \\
27.8 \\
28.6 \\
34.5\end{array}$ \\
\hline $\begin{array}{l}\text { Esso } \\
\text { Bitumen } \\
\text { Blend }\end{array}$ & $\begin{array}{l}0.6 \\
0.6 \\
1.0 \\
5.0\end{array}$ & $\begin{array}{l}- \\
+ \\
+ \\
+\end{array}$ & $\begin{array}{l}17.0 \\
41.4 \\
51.8 \\
65.1\end{array}$ & $\begin{array}{l}25.7 \\
59.0 \\
71.2 \\
87.7\end{array}$ & $\begin{array}{l}20.5 \\
25.0 \\
28.0 \\
32.2\end{array}$ \\
\hline
\end{tabular}

Table 2.18. Effect of process performance on product quality.

\begin{tabular}{|c|c|c|c|}
\hline $\begin{array}{l}\text { Experimental } \\
\text { procedure }\end{array}$ & $\begin{array}{l}\text { Yield } \\
(\%)\end{array}$ & $\begin{array}{c}\text { Combustibles } \\
\text { Recovery } \\
(\%)\end{array}$ & $\begin{array}{l}\text { Ash } \\
(\%)\end{array}$ \\
\hline Byron Creek Reject & - & - & 47.1 \\
\hline Single-stage & 57.5 & 82.6 & 28.6 \\
\hline $\begin{array}{l}\text { Wet grinding } \\
\text { followed by } \\
\text { by single-stage }\end{array}$ & 64.5 & 86.3 & 30.3 \\
\hline Two-stage & 49.4 & 73.3 & 22.6 \\
\hline
\end{tabular}

Nole: All values on dy basis.

Table 2.19. Recovery of combustble material from precipitator dust.

\begin{tabular}{lcccccc}
\hline $\begin{array}{l}\text { Exporimental } \\
\text { procedure }\end{array}$ & $\begin{array}{c}\text { Proceses Conditions } \\
\text { Oll } \\
\text { addition } \\
(\%)\end{array}$ & $\begin{array}{c}\text { Moditiors } \\
\text { Surfact }\end{array}$ & Doprese. & $\begin{array}{c}\text { Ylold } \\
(\%)\end{array}$ & $\begin{array}{c}\text { Combustiblo } \\
\text { Recovery } \\
(\%)\end{array}$ & $\begin{array}{c}\text { Ash } \\
(\%)\end{array}$ \\
\hline Initial Sample & - & - & - & - & - & 27.5 \\
\hline Aglofibat & 3.75 & - & - & 69.4 & 85.1 & 10.2 \\
& 3.00 & + & - & 65.3 & 82.1 & 9.6 \\
\hline Agglomeration & 3.00 & - & + & 68.3 & 86.2 & 9.3 \\
\hline
\end{tabular}

\section{Obed Preclpitator Dust}

A sample of precipitator cust from a coal washing plant was tested for beneficiation using the Aglofloat process procedures. The results of several bench tests using a combination of bridging oil at different concentrations plus surface modiliers are shown in Table 2.19. The results show consistently low yields and combustibles recovery (80 to 90 percent) as compared to the Aglofloat results for U.S. coals (in the high 90's). What is interesting, is that with the Aglofloat process the recovery of Obed washed coal was much better than the recovery of Obed precipitator dust (Table 2.20). High yield and high combustibles recovery (95 percent) were achieved for all runs with Obed washod coal including those with oil concentrations of 1 percent and those in which surfactants were used. This suggests that specially suited surfactants might improve recovery of Obed precipitator dust.

In an attempt to obtain better ash reduction in Obed washed coal, two coal samples of different sizes were processed using the Aglofloat procedure.
The results suggest (Table 2.21) that ash in the coal is uniformly and finely distributed and that further pulverization would provide little improvement in ash removal.

A summary of the test results with Obed precipitator dust, using different additives is depicted in Table 2.22. It is shown that by using a combination of additives and bridging oil concentrations. good ash reduction and reasonable combustibles recovery can be obtained. The procedures call for high oil concentration ( 3 percent) as compared to the bridging oil concentration for U.S. bituminous coals ( 0.5 percent).

\subsubsection{Green Agglomerates Handling}

A two-step procedure was tested for drying of green agglomerates: 1) pressure filtration of the agglomerates; and 2) subsequent low temperature drying of pellets made from pressure fitter cake (Figure 2.8, Table 2.23). The results suggested that dry, solid agglomerates can be obtained by pelletizing the clean coal filter cake. 
Table 2.20. Beneficiation of Obed washed coal by Aglotbat process:

\begin{tabular}{|c|c|c|c|c|}
\hline \multirow[b]{2}{*}{ Addtives } & \multirow[b]{2}{*}{$\begin{array}{l}\text { nold } \\
(\%)\end{array}$} & \multirow{2}{*}{$\begin{array}{c}\text { Combustlble } \\
\text { Recovery } \\
(\%)\end{array}$} & \multicolumn{2}{|c|}{$\operatorname{Ash}(\%)$} \\
\hline & & & Actual & Rojection \\
\hline Initial foed & & & 14.2 & - \\
\hline+ & $\begin{array}{l}95.8 \\
92.2 \\
93.3\end{array}$ & $\begin{array}{l}99.2 \\
96.1 \\
97.3\end{array}$ & $\begin{array}{l}11.0 \\
10.5 \\
10.6\end{array}$ & $\begin{array}{l}-26 \\
-31 \\
-30\end{array}$ \\
\hline
\end{tabular}

Noto: All values on dry basis.

a: Conditions: Solids concentration - 20\% on dy basis; Bridging liquid - bitumen \& diesel (2:3); Oil addition - $1 \%$ on dy solids.

Table 2.21. Beneficiation of Obed washed coal by Aglofbat processa.

\begin{tabular}{lcccc}
\hline $\begin{array}{l}\text { Particle } \\
\text { Size } \\
(\mathrm{mm})\end{array}$ & $\begin{array}{c}\text { Yold } \\
(\%)\end{array}$ & $\begin{array}{c}\text { Combustlbles } \\
\text { Recovery } \\
(\%)\end{array}$ & $\begin{array}{c}\text { Actual (\%) } \\
\text { Rojection }\end{array}$ \\
\hline Initial foed & & & 14.2 & - \\
\hline $100 \%$ minus 300 & 92.2 & 96.1 & 10.5 & -31 \\
$100 \%$ minus 150 & 94.9 & 98.1 & 10.9 & -25 \\
\hline
\end{tabular}

Note: All values on dry basis.

a: Conditions: Solids concontration - $20 \%$ on dy basis. Bridging liquid-mixture of bitumen and diesel; Oil addition - $1 \%$ on dy basis.

\subsection{Conclusions}

Cleaning of bituminous coal was demonstrated using the Aglofloat process in the batch laboratory experiments. Addition of a combination of bridging oil and surfactant, in single- and two-stage Aglofloat procedures tests, resulted in product agglomerates with a heating value of 13,000 Btu/b or less, ash comtent of 10 percent or more, and reduced total sulphur content of 30 percent or better. Total pyritic sulphur in coal was reduced up to 95 percent.

Two types of tests were used in the laboratory experiments: single-stage and two-stage tests. The two-stage Aglofloat procedure was a combination of two single-stage tests with inter-stage grinding.

Six high sulphur bituminous coals from the U.S. and four $\infty$ al products and by-products from preparation plants in Alberta were evaluated. In general, the Aglofloat procedures and bridging oil formulation developed for U.S. coal did not pertorm well with the Alberta coals, and special bridging oil formulations which included the addition of surfac. tants were required for the Alberta coals.
Table 2.22. Beneficiation of Obed precipitator dust.

\begin{tabular}{|c|c|c|c|c|c|}
\hline $\begin{array}{l}\text { Experl- } \\
\text { mental } \\
\text { procedure }\end{array}$ & $\begin{array}{l}\text { Oll } \\
\text { addition } \\
(\%)\end{array}$ & Additives & $\begin{array}{l}\text { C } \\
\text { Yiold } \\
(\%)\end{array}$ & $\begin{array}{l}\text { ombustlbles } \\
\text { Recovery } \\
(\%)\end{array}$ & Ash \\
\hline \multicolumn{3}{|c|}{ Initial Feed } & - &. & 27.7 \\
\hline $\begin{array}{l}\text { Single- } \\
\text { Stage } \\
\text { Aglotbat }\end{array}$ & $\begin{array}{l}3.0 \\
3.0 \\
3.0 \\
3.75\end{array}$ & $\begin{array}{l}\text { Surfactant } \\
\text { Depressant } \\
\text { Surf.+Depr. } \\
\text { Surfactant }\end{array}$ & $\begin{array}{l}65.3 \\
68.3 \\
67.8 \\
69.4\end{array}$ & $\begin{array}{l}82.1 \\
86.2 \\
85.5 \\
85.1\end{array}$ & $\begin{array}{r}9.6 \\
9.3 \\
9.4 \\
10.2\end{array}$ \\
\hline $\begin{array}{l}\text { Aglofbat } \\
\text { followed } \\
\text { by Ag- } \\
\text { glomeratio }\end{array}$ & $\begin{array}{r}16.75 \\
(3.75+ \\
13.4) \mathrm{a}\end{array}$ & Surfactant & 70.0 & 84.2 & 7.9 \\
\hline
\end{tabular}

a: Oil addition in each step

Table 2.23. Dewatering of Aglofloat producta by pressure fikrationb.

\begin{tabular}{lccc}
\hline Product & $\begin{array}{c}\text { Cake-forming } \\
\text { time(s) }\end{array}$ & $\begin{array}{c}\text { Drying } \\
\text { time(s) }\end{array}$ & $\begin{array}{c}\text { Cake } \\
\text { molsture } \\
(\%)\end{array}$ \\
\hline Singlo-Stage & 8 & - & 28.4 \\
\hline Two-Stage & 8 & 120 & 17.6 \\
\hline & 12 & - & 59.3 \\
\hline
\end{tabular}

a: Upper Freeport coal; Bitumen and diesel (2:3) - bridging liquid; Oil addition $-0.6 \%$ for single-stage procedure; $1.0 \%$ for two-stage procedure.

b: Conditions: Pressure - 40 psi; Cake Thickness - $16 \mathrm{~mm}$.

Tests comparing the performance of single- and two-stage Aglofloat with the U.S. coals showed that although the two-stage process resulted in the removal of more ash and inorganic sulphur, it also resulted in a higher loss of combustible materials. The choice of single- or two-stage process would therefore depend on the level of cleaning and coal recovery required for each specitic coal.

Comparison of the single-stage process to the float and sink test suggested that both can be used as a measure of the ease with which mineral matter can be separated. The washability curves were similar for both methods.

Good separation of mineral matter and pyrite was obtained for a wide range of coal and oil concentrations. However, with oil concentrations less than 0.5 percent, combustibles recoveny decreased rapidly. The minimum oil concentration required depended on the coal properties, e.g. Byron Creek tines required 5 percent of oil for a 95 percent combustibles recovery while llinois No. 6 required only 1 percent. 
Bridging oil properties did not significantly affect the Aglofloat performance, provided that the content of diesel in the bridging oil was kept above 40 percent. At lower diesel oil concentrations, with Cold Lake bottom, the Aglofloat performance deteriorated. The performance could, however, be restored with the addition of surfactants, suggesting that poor coal recovery might have been due to a lesser affinity of the major bridging oil component (Cold Lake bottom) for coal.

A series of separate tests were conducted with westem Canadian coals to modify the Aglofloat procecures for these coals. With these coals the Aglofloat performance was more affected by the bridging oil concentration and properties, by the surfactants added, and by the coal properties than was the case with U.S. coals. As a result, a special bridging oil formulation was developed for western Canadian coals. The Aglofloat procedure as modified for use with western Canadian coals also required the addition of 3 percent of oil versus 0.5 percent for the U.S. bituminous coals.

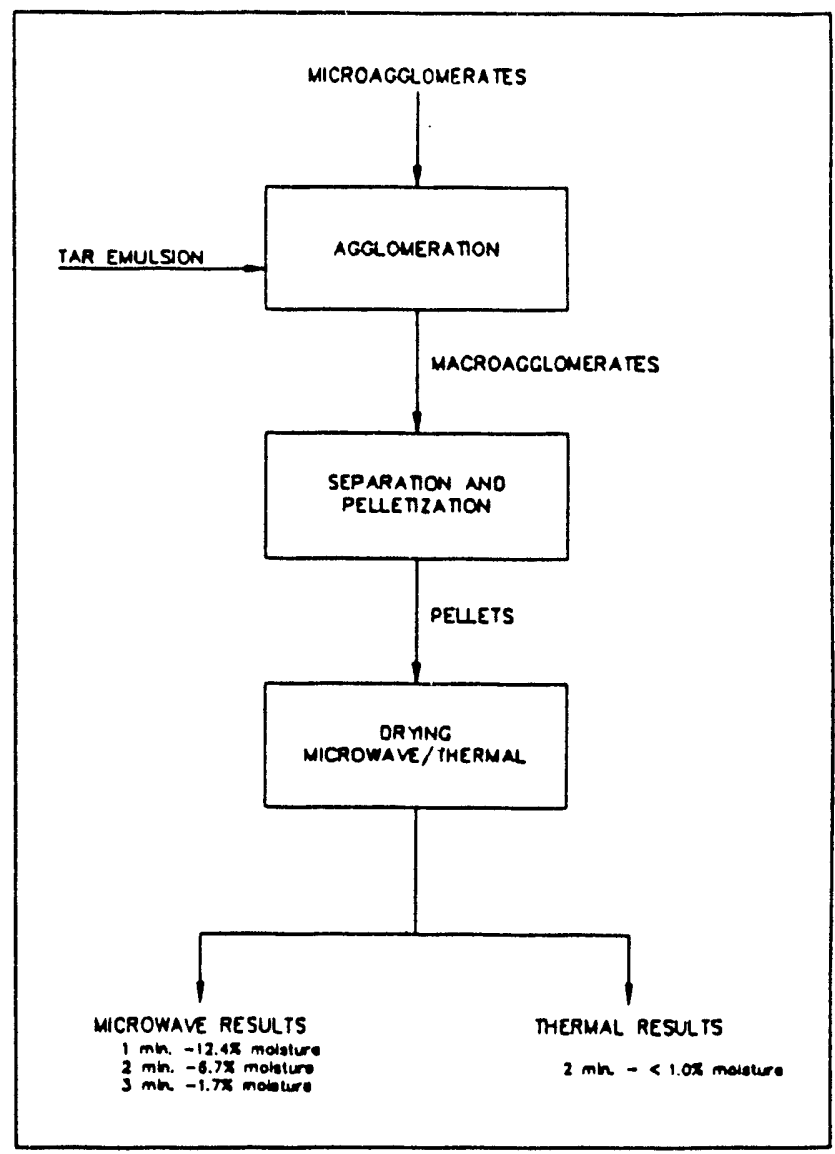

Figure 2.8. Green agglomerates drying tests. 


\section{Design Studies of Agglomeration Mechanisms}

\subsection{Fundamentals of the Aglofloat Process}

In Volume 1, "Upgrading of Low Rank Coals: the Agflotherm Process", a model of spherical agglomeration for prediction of the growth pattern of the agglomerates was presented. However, this description was limited to agglomeration cunditions characterized by over-critical bridging oil concentration. This section, describes the model's principles and application in conditions characterized by undercritical bridging oil concentration, conditions which are more relevant when explaining agglomeration mechanisms in the Aglofloat process.

Like agglemeration in the Agflotherm process, agglomeration in the Aglofloat process begins with the formation of pellets from finely pulverized coal particles suspended in water. Agglomeration results from inter-particle collisions and adhesion of particles in a high shear agitation vessel in the presence of bridging liquid. The integrity of the agglomerate depends very much on the capillary forces caused by the presence of bridging oil between the particles. The strength of the capillary forces, which determines the tensile strength of the agglomerate, depends on the amount of bridging oil in the pore structure of the agglomerate.

The states of liquid saturation have been identified as pendular, funicular and capillary (Figure 3.1). In the pendular state, a small quantity of oil resulis in formation of liquid bridges between individual par-

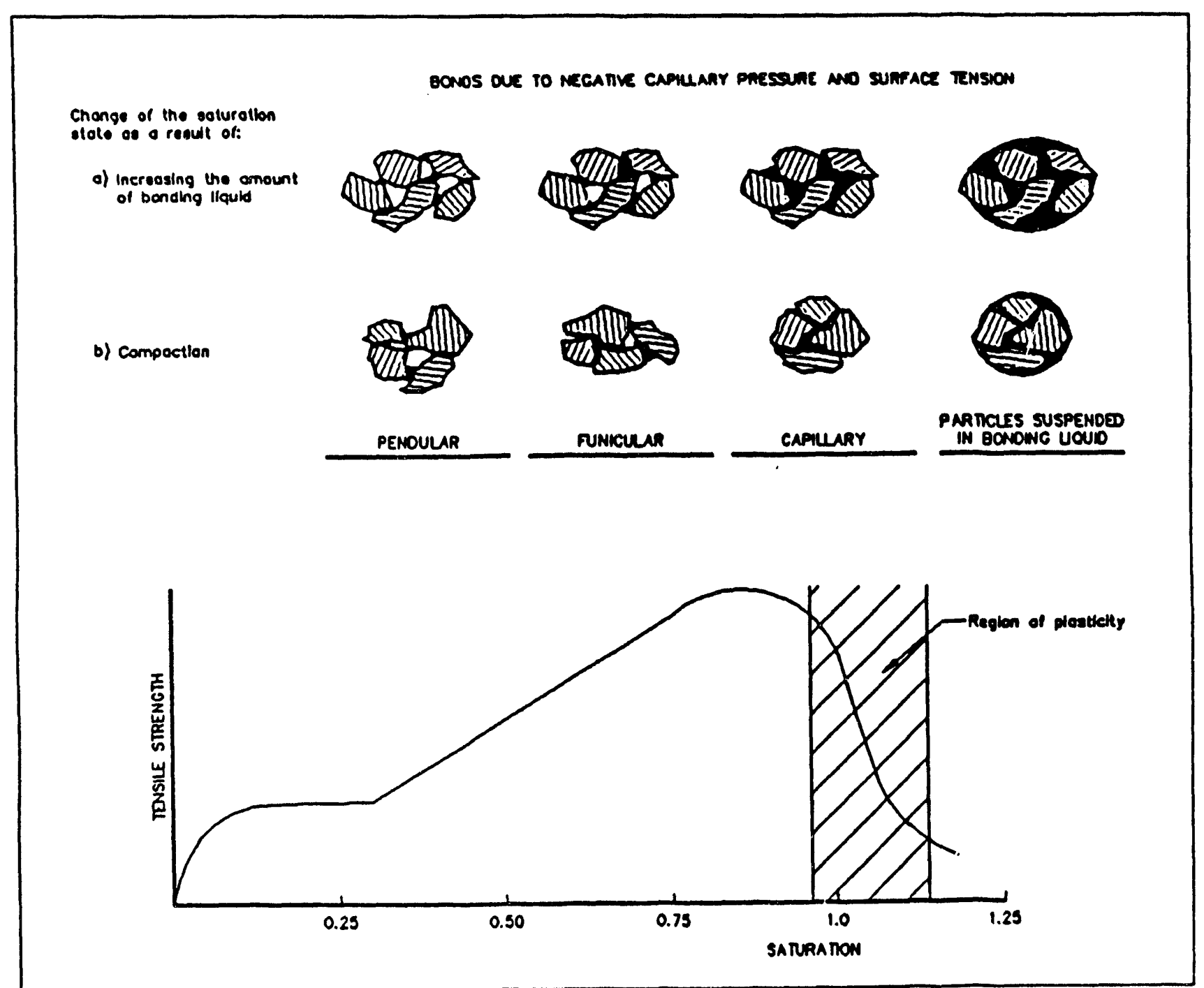

Flgure 3.1. Schematic representation of agglomerates formation. 
ticles. In the funicular state, oil bridges coexist abng with some pores which are filled totally with bridging oil, while in the capillary state the pore space be. tween particles is completely filled with oil.

Figure 3.1 depicts the relationship between the strength of the agglomerates and bridging oil saturation. The agglomerates' strength approaches its maximum when saturation exceeds 0.8 , i.e., at its capillary state.

\section{Growth Pattem for Under-Critical Oll Addition}

Szymocha et al. (1989) have recently presented a model of a spherical agglomeration process based on the ARC and University of Alberta work on coal agglomeration in pipeline loops and stirred vessels and on published models of agglomeration. The model presents a number of technical implications for the Aglofloat process, as well as conceptualiza. tions of the process. Some of the key features of the mechanism of this model are presented below.

The model postulates that the growth of agglomerates proceeds in a step-wise manner with three growth steps distinguished, l.e., primary, secondary and tertiary agglomerates formation steps (Figure 3.2). Each growth step is characterized by a different growth rate, growth factor and duration. Depending on the complexity of the system and the agglomeration condition we can see a succession of the agglomerates saturation states (pendular, funicular and capillary) for each growth period (Figure 3.3). A description of each growth period presented in Figure 3.3 is given below.

Wetting Ferlod: No growth of agglomerates is observed in this period. The intensive mixing of the coal-water and bridging oil slurry results in dispersion of the bridging oil into fine droplets which are absorbed into the coal particles. The wetting period ends with phase inversion, i.e., the stumy suspension changes color and small flocs made of coal and bridging oil are formed. The inversion is considered complete when the slumy starts to show separation between coal and mineral matter.

Growth Perlod: This period starts with the thickening of the flocs and their coalescence, and with formation of primary agglomerates. The state of the primary agglomerates changes from penctular to funicular which results in an increase in the strength of the agglomerates. The number of particles per aggregate may range from two to five, depending on the bridging oil concentrations, with the agglomera-

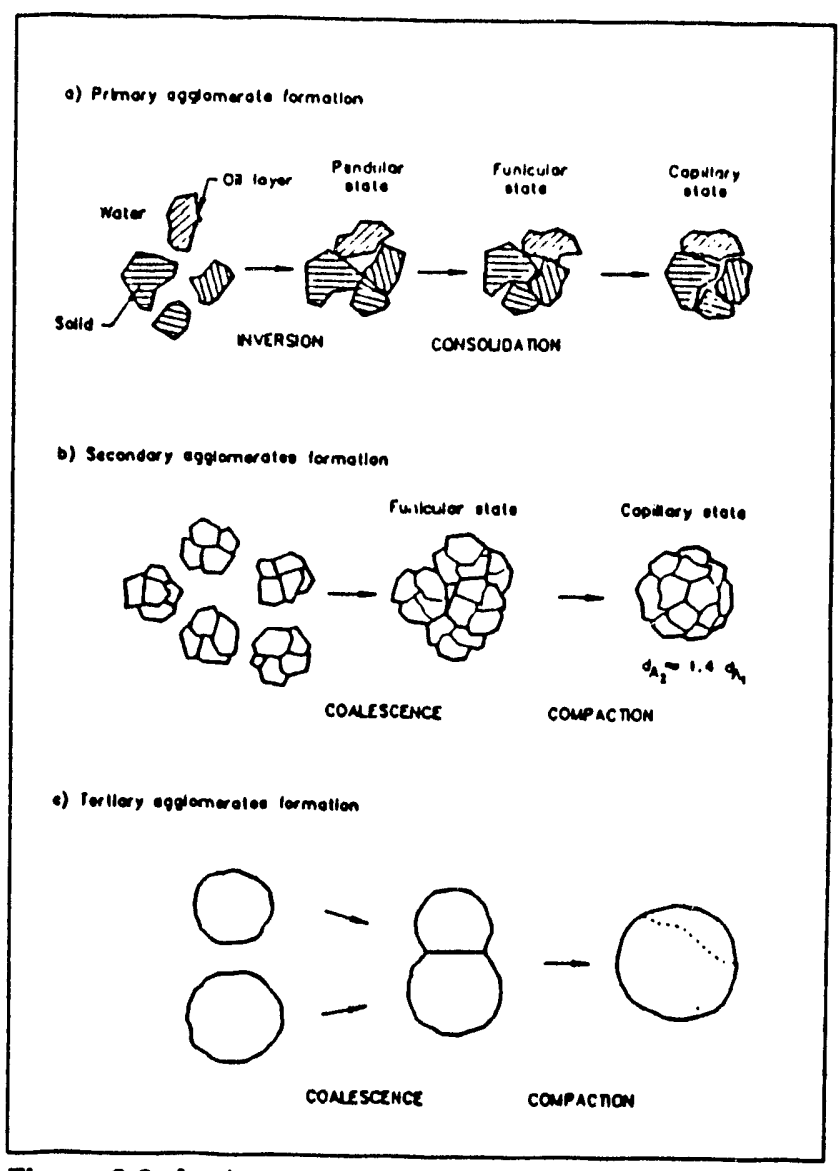

Flgure 3.2. Agglomerate formation stages.

tion and redispersion of the aggregate acting as size averaging factors.

Consolldation Perlod: The agglomerates are further densified (compacted) during the consolidation period and porosity of the agglomerates is gradually reduced with available bridging oil filling up the pore space. The result is a shift of agglomerates from a funicular to a capillary state and a further increase of agglomerates' strength. In this state, referred to as the dry surface state, the amount of bridging oil at the aggiomerate surface (outside) is not sufficient to coalesce the impacting agglomerates. However, as agglomeration proceeds, further densitication of the agglomerates results in the "squeezing out" of the bridging oil, and formation of a wet surtace state which is reflected in lower strength and increased plasticity of the agglomerates. The increased plasticity of the agglomerates sets a favorable condition for deformation and coalescence of the surface wet 


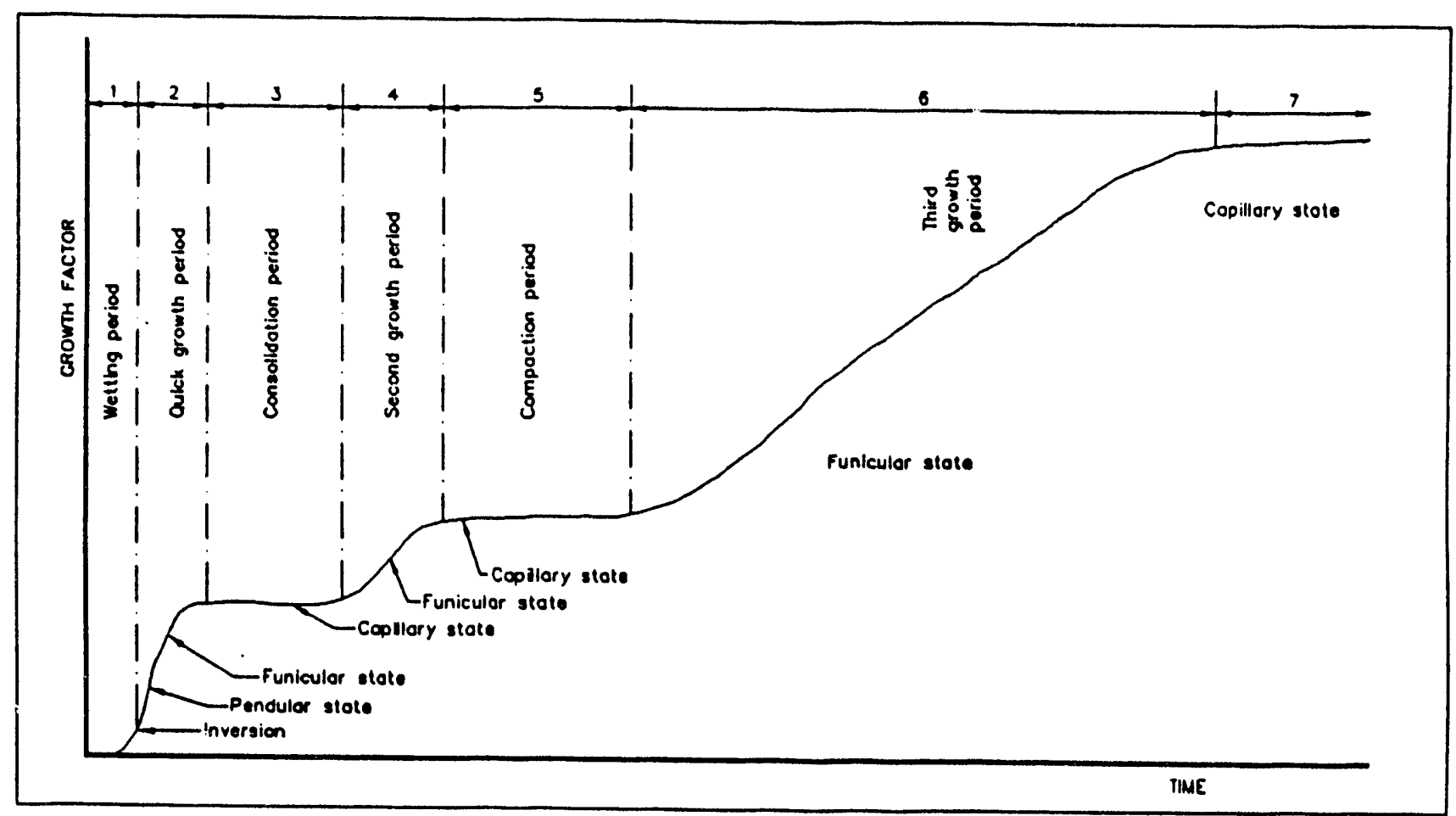

Figure 3.3. Relationship between growth factor, growth periods and oil saturation states.

agglomerates, and for initiation of the second growth period.

Second Growth Period: In the secund stage of agglomerate growth, primary agglomerates aggregate into larger secondary agglomerates which have a "raspberry" type structure, and, initially, are in a funicular state (Figure 3.2b). Tho growth rate is determined by the fusion of the primary agglomerates, which depends on the plasticity of the aggregate.

Compaction Perlod: The assemblages created during the second agglomerate growth period are in the funicular state. Subject to compaction, the secondary agglomerates undērgo plastic deformation and porosity reduction and gradually acquire a spherical shape and a smooth surface. They can be in a dry or wel surface state depending on the bridging oil concentration. If they are in a wet surface state, the agglomerates will undergo a third growth period.

Third Growth Perlod: Typically at this stage, the assemblages are already large and further growth involves collision of these assemblages, usually in pairs, to create bigger ones. After compaction, newly created assemblages can participate once more in the growth process (collision, bonding, deformation, compaction) until a final ory surface state is achieved. The final size of the agglomerates is, therefore, a function of the amount of bridging oil.

Equillbrlum Perlod: After reaching the final dry state, the agglomerates are very strong and rigid. They do not possesss sufficient plasticity to delorm and form bonds on collision. The "equilibrium" state agglomerates can keep a constraint size for a prolonged time. In one experiment reported, it took over 300 hours of hydrotransportation before any breakage occurred (Pawlak el al., 1985).

\section{Effect of Bridging O.I Additior on Final Agglomerate Size}

Four different growth pattems can be distinguished depending upon the amount of bonding liquid regions $A, B, C$, and $D$ in Figure 3.4. Each region is characterized by a different number of growth periods and different growth factors. For example, in region $A$, for relative oil concentration below 0.42 , only one growth period is observed. The primary ag. glomerates achieve a final size which does not undergo any further changes under prolonged agitation. Growth factor $d^{*}$ for region A varies from 1 (at $\left.C^{*}=0.04\right)$ to $1.6\left(\right.$ at $C^{*}=0.42$ ). Where 


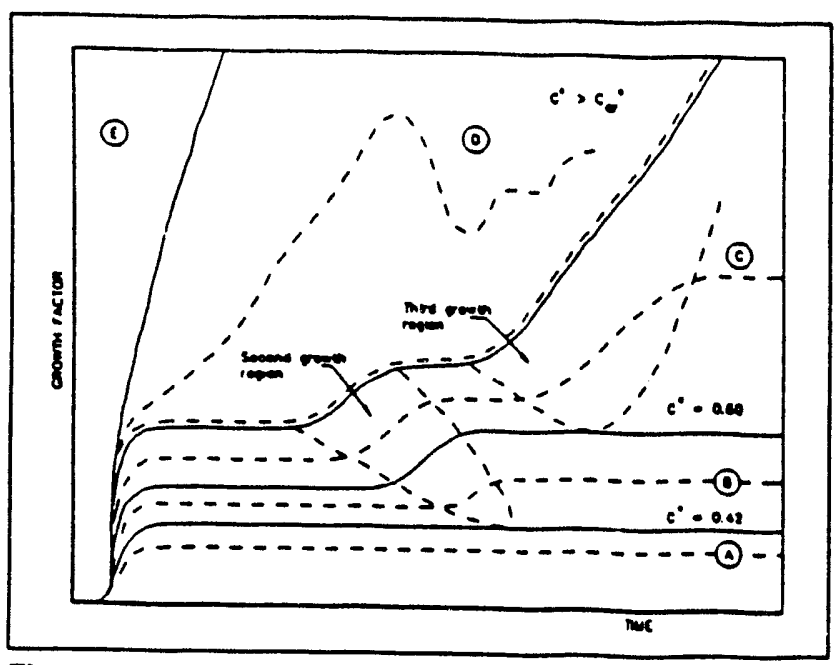

Figure 3.4. Growth regimes for the agglomeration process.

and

$$
C=\frac{c_{0}}{c_{\text {oct }}}
$$

$\mathrm{C}_{0}=$ oil concentration, \% d.a.f. basis

$\mathrm{C}_{\text {oct }}=$ critical oil concentration, \% d.a.f. basis

In region $B$ (i.e., relative oil concentrations $C^{*}$ in the range from 0.42 to 0.60 ), growth takes place in two steps. In the first step, the growth factor increases from $1.6\left(\right.$ at $C^{*}=0.42$ ) to 1.9 (at $C^{*}=0.60$ ), and for the second step, from 1 to 1.4. As a result of this two-step growth, the particle size increases from 1.6 (at $C^{*}=0.42$ ) to 2.6 (at $\left.C^{*}=0.60\right)$. In region $B_{\text {, }}$ as compared with region $A$, a bnger agglomeration time is needed to complete the growth of agglomerates.

In region $\mathrm{C}$, three growth steps are distinguished. In the first step, the size of agglomerates increases from 1.9 (at $C^{*}=0.60$ ) to $2.60\left(\right.$ at $C^{*}=1.0$ ). In the second step, the size increases by a factor of 1.4. Figure 3.4 shows the increase in size ouring the third growth step. In region $\mathrm{C}$, the time required to reach the final size is significantly longer than for region $\mathrm{B}$.

If oil concentration exceeds the critical value (C" 1), growth accelerates; growth periods start overlapping and eventually becorne indistinguishable. In region $D$, the agglomerates grow very quickly, but their growth rate varies remarkably and finally the system enters the size instability region. As the relative oil concentration increases, the maximum size

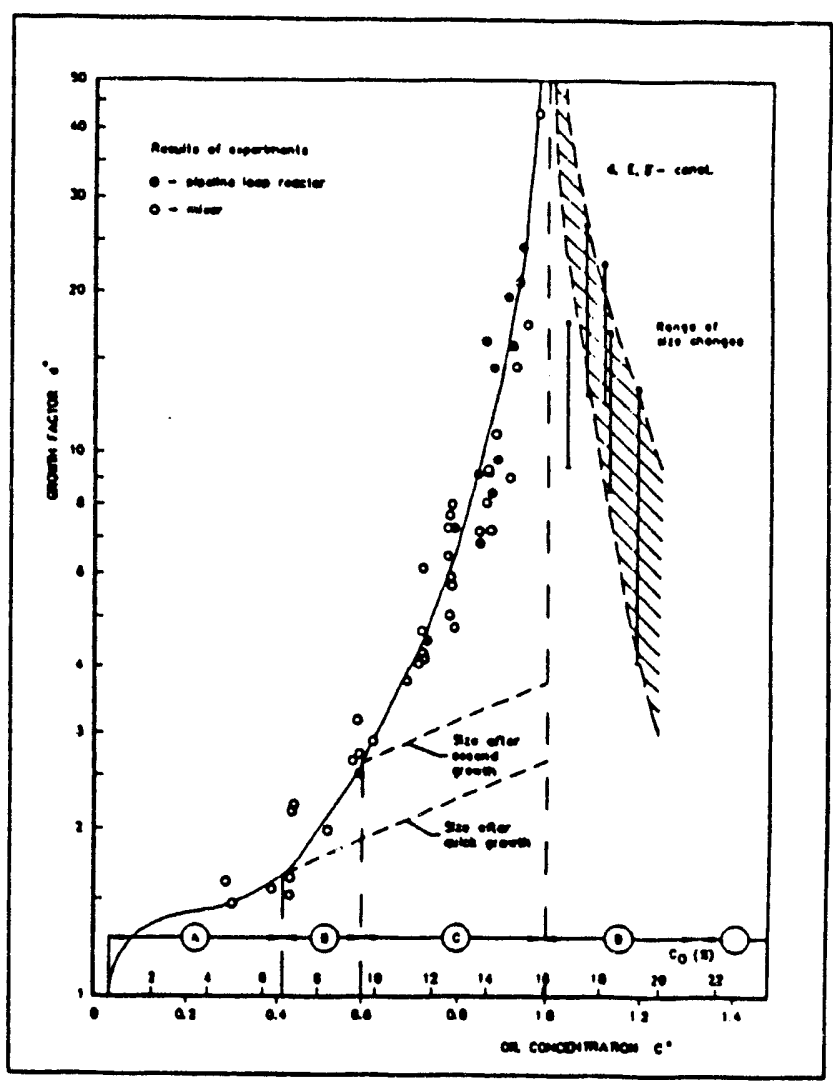

Flgure 3.5. Relationship between growth factor and oil concontration.

of agglomerates diminishes. In region E (see Figure 3.4), because of a significant excess of oil, agglomeration does not proceed and the product is recovered in the form of a paste.

Experimental results for a range of oil-coal concentrations are presented in Figure 3.5. These results support the Sherrington model (Sherrington, 1968) and contirm that the median diameter of the agglomerates increases exponentially with the amount of bridging liquid.

The relationship between the growh factor $d^{\circ}$ and the oil concentration $C_{0}$ can be obtained from the following equation:

$$
d^{*}=\frac{t}{1 \cdot\left[\frac{1-\varepsilon}{\varepsilon} \frac{q_{s}}{q_{L}} \frac{c_{0}}{100}\right]^{1 / 3}}
$$

Where:

$d^{*}=$ growth factor $\left(d_{A} / d\right)$

$t=$ withdrawal factor 


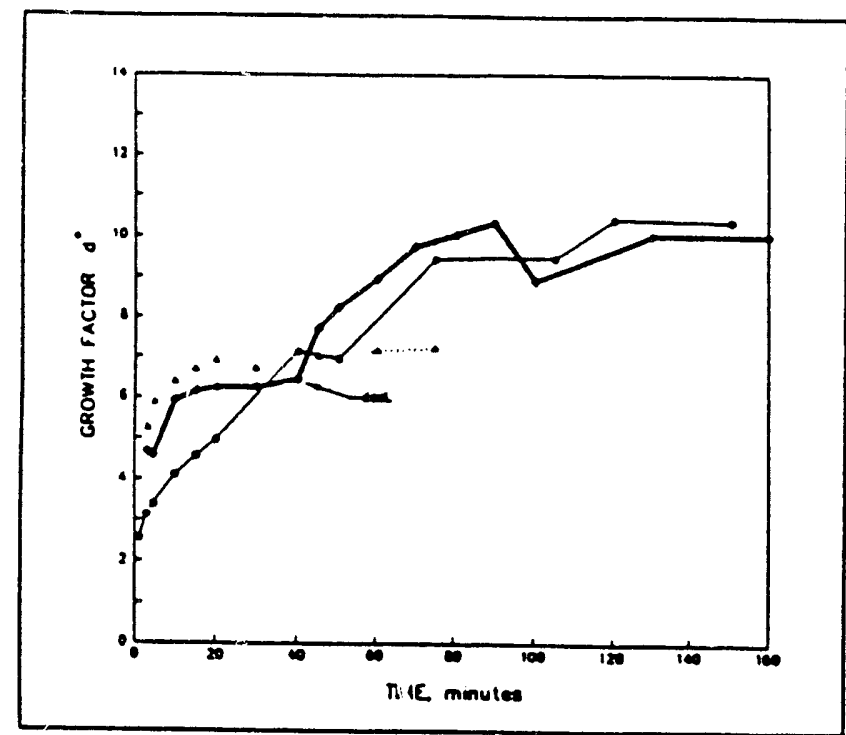

Mgure 3.6. Kinetics of Agglomeration process of llinois $\$ 6$ cal. $\mathrm{d}_{50}=225 \mu \mathrm{m}, 1800 \mathrm{rm} ; \mathrm{d}_{50}-40 \mu \mathrm{m}, 1800$ rpm; $\Delta d_{50}=40 \mu \mathrm{m}, 1820 \mathrm{pm}$.

$\varepsilon=$ porosity of agglomerate (dimensionless)

$q_{S}=$ solid density $\left(\mathrm{kg} / \mathrm{m}^{3}\right)$

$q_{L}=$ liquid ćensity $\left(\mathrm{kg} / \mathrm{m}^{3}\right)$

$\mathrm{C}_{0}=$ oil concentration, $\%$ d.a.f. basis

\subsection{Batch Tests and Results}

\subsubsection{Kinetics of Bituminous Coal Aggiomeration}

Szymocha, et al. (1989) report that several factors influence the kinetics of coal agglomeration and the size of coal-oil agolomerates. A list of these factors appears in Section 3.2.1. Votume 1 of this report.

The selected key factors studied in the agglomeration of bituminous coals were:

- coal particle sizo

- intensity of mixing

- oil concentration

- solids concentration

- coal desliming

- design of the mixer.

The results of the completed tests are depicted in Figures 3.6 to 3.10. The key conclusions which can be drawn from these tests are:

- The mean coal particle size, $d_{50}$, had an effect on the grouth factor at the beginning of the process

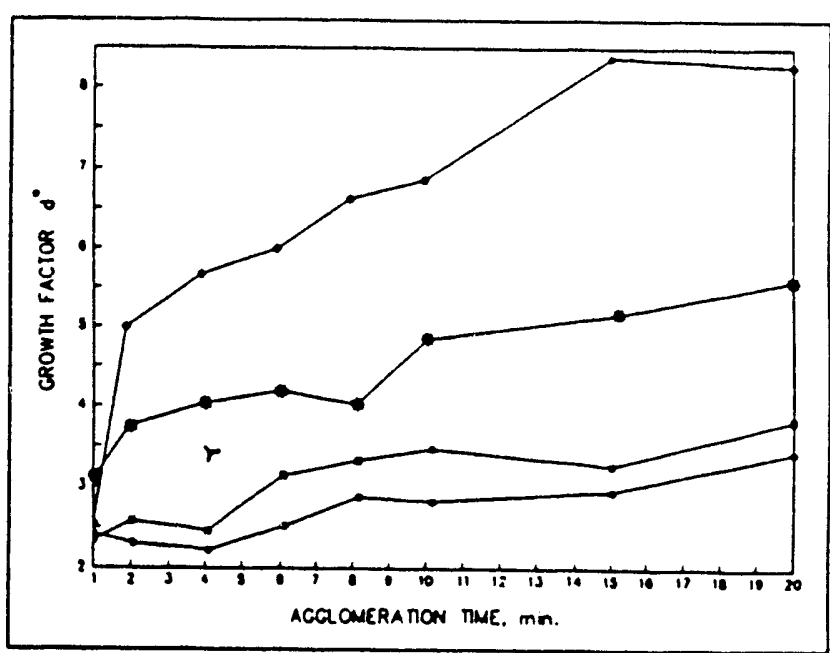

Figure 3.7. Kinetics of Agglomeration process for Dodds $\infty$ al. $-C_{0}=14 \% ;-C_{0}=18 \% ; \cdot C_{0}=22 \% ; \diamond C O=26 \%$.

(up 1040 minutes). When the agglomeration time was extended ( $40 \mathrm{~min})$, the difference in growth factors for the particle size studied appeared to be negligible.

- Higher bridging oil concentration leads to larger growth factors at all agglomeration times (Figure 3.7). The effect of bridging oil concentration appears to be much stronger than the effect of factors such as intensity of mixing.

- The growth factor can sometimes vary quite significantly with only a small difference in bridging oil concentration, provided that sufficient agglomeration times are allowed (Figure 3.8).

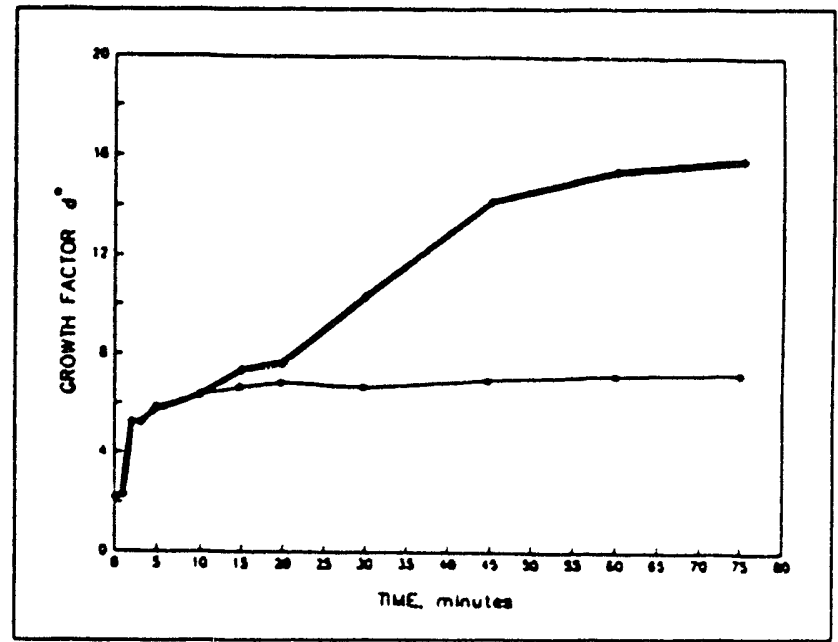

Flgure 3.8. Influence of oil addition on growth aggtomerates from lllinois coal (Mixer M-260), $\cup C_{0}=11 \%$; $\mathrm{C}_{0}=12.5 \%$. 


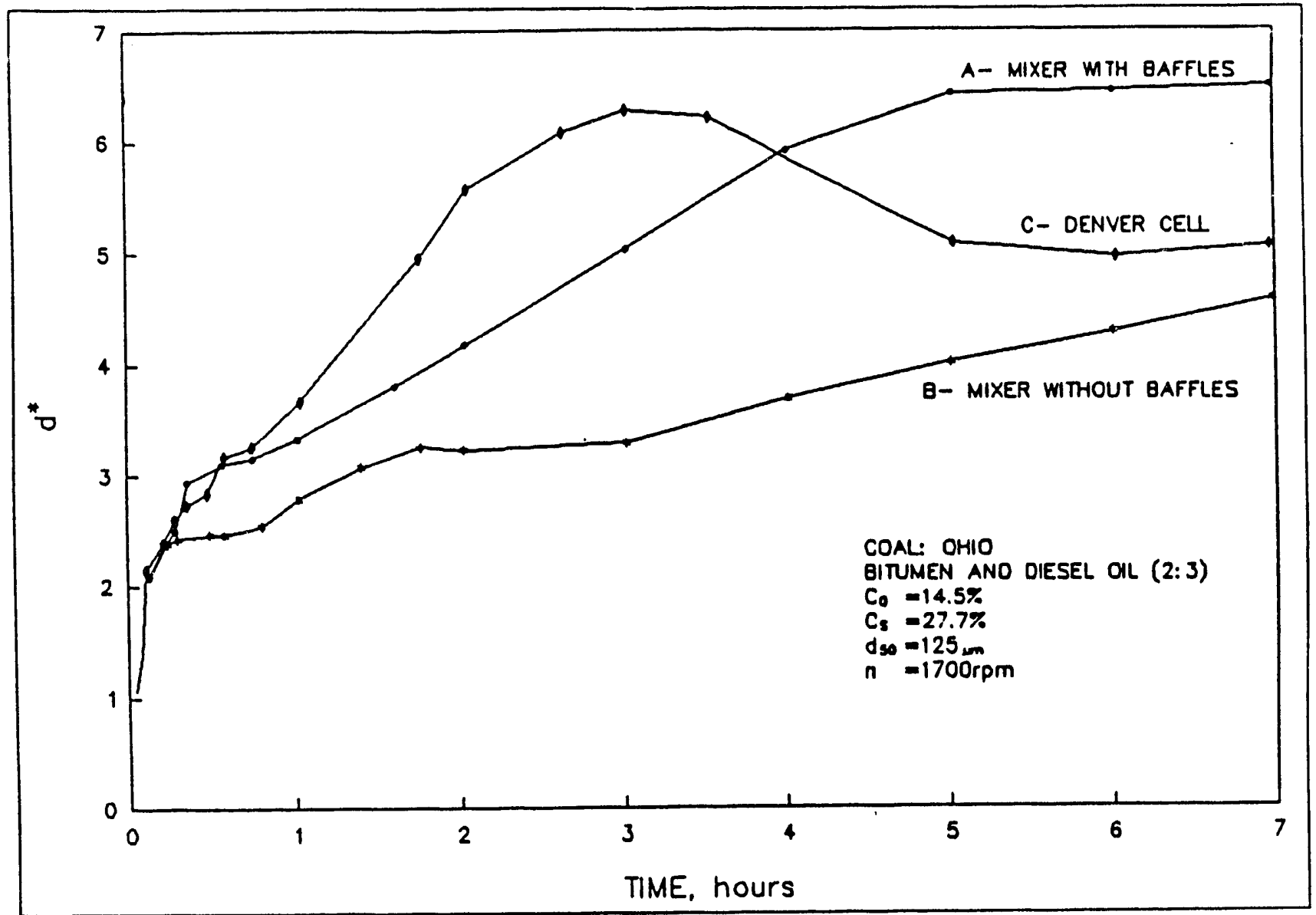

Flgure 3.9. Batch tests on kinetics of the agglomeration process for Ohio coal.

- Design of the mixer can have a strong effect on the rate of growth and on the size of the product (Figure 3.9). Presence of baffles in the mixer often improves the agglomeration kinetics and product size.

- Desliming of coals containing a high percentage of mineral matter was found to have a significant effect on the agglomeration kinetics and the size of the agglomerates. Reduction of mineral matter content increased the agglomerate size by a factor of 2 (Figure 3.10).

\subsection{Conclusions}

A model describing the growth pattem of agglomerates during application of the Aglofloat process was developed. The model suggested that for under-critical bridging oil concentrations the size of the agglomerates depends on the amount of bridging oil. The model also postulated that the growth of agglomerates proceeds in a step-wise manner with three growth steps, each characterized by a different growth rate, growth factor and duration.

The effect of bridging oil addition on final agglomerate size was described by an empirical equation correlating the growth factor $d^{\circ}$ and the oil concentration in the agglomerates. The experimental results showed good correlation between the predicted and actual agglomerates growth, at different oil concentrations. The strength of the agglomerates depends on the amount of oil. compaction and pore structure of agglomerates (Schubert, 1977, Tanaka et al, 1985).

The batch kinetic tests showed that the key factors influencing the agglomeration of bitumen coals were:

- coal particle size, 


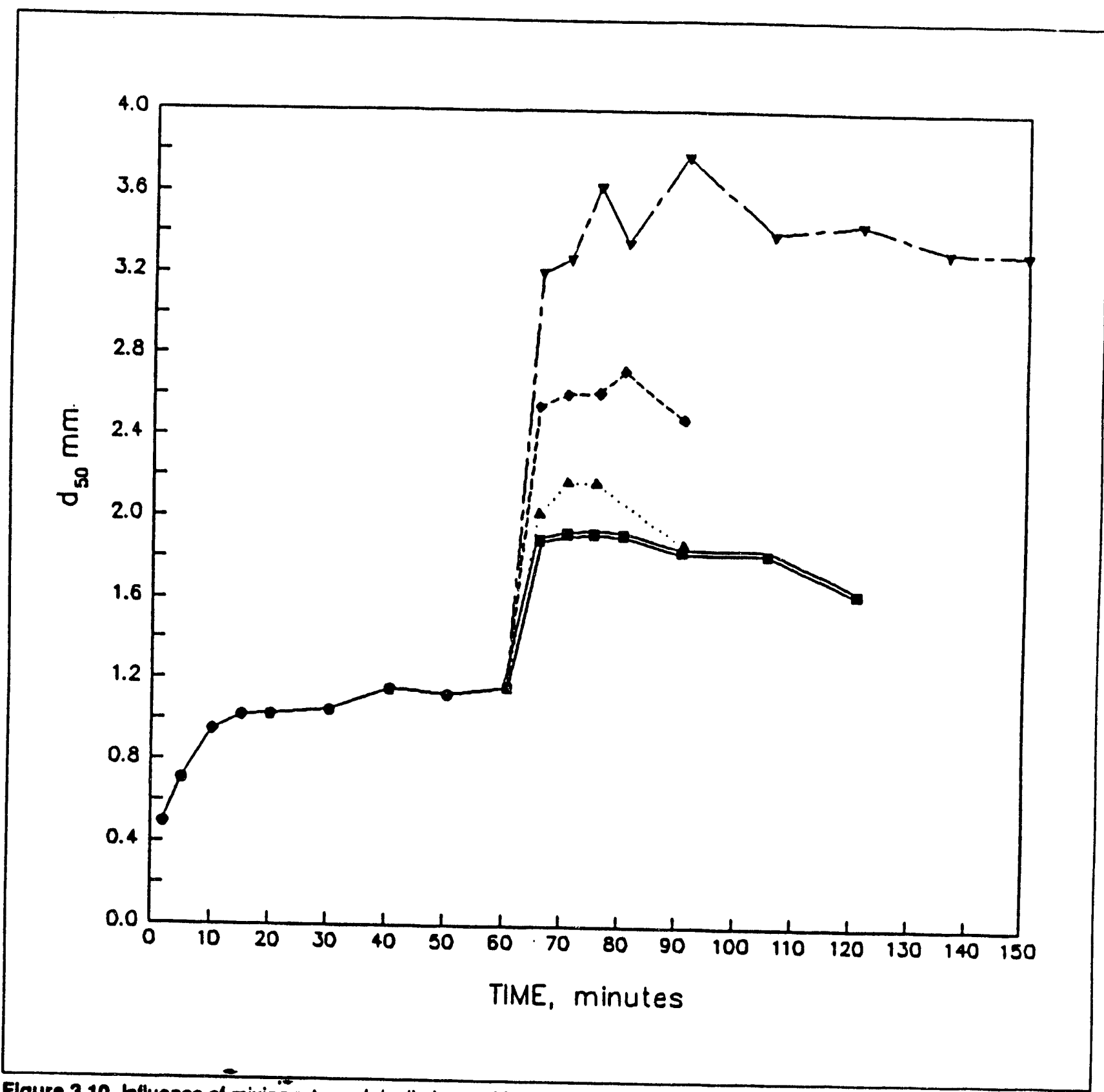

Flgure 3.10. Influence of mixing rate and destiming on kinetics of agglomeration for Highvale coal. $\mathrm{M}-260$, $d_{50}=260 \mu \mathrm{m} ; \square M-2,1800 \mathrm{pm} ; \triangle M-2,1800$ pm desl.; $\bullet$ M-2, 1300 pm, desl.; $\nabla M-2,1300$ rpm desl. no baffles.

- intensity of mixing,

- oil concentration,

- coal desliming, and

- design of the mixer.

The full effect of these factors on the agglomerate kınetics was considered in the development of the

bench-scale continuous pyrite removal unit (CPRU) .and pibt plant facilities (IATF) for the Aglofbat process. Details of the designs and experimental results oblained in the CPRU and IATF are presented in Chapter 4 and 5 of this report. 


\section{Continuous $5 \mathrm{~kg} / \mathrm{hr}$ Pyrite Removal Unit (CPRU)}

\subsection{CPRU Design for the Aglofloat Process}

The overall objectives of the Continuous Pyrite Removal Unit (CPRU) was to study the removal of small pyrite particles from the floatation flocs (see Appendix 3 ) and to investigate the process performance for different equipment configurations, particularty the flume (stationary bed) separator. A graphic representation of the flume separator appears in Appendix 3. The specific objectives were to evaluate the technical feasibility of using the flume and hydraulic separators for pyrite removal, to develop design criteria for scale-up of the hydraulic separator, and to assess the separator performance in terms of combustibles recovery and sulphur reduction.

\subsubsection{CPRU Design Specifications}

The bench-scale, continuous unit included equipment for conditioning of coal-water stumy, for agglomeration of the stumy, for floatation of the microagglomerates, and for pyrite separation from the coal flocs (microagglomerates).

The nominal design specifications for the CPRU were:

Solld Throughput: 2.5 to $7.5 \mathrm{~kg} / \mathrm{hr}$ of coal (as received).

Equipment Configuration: a slurry conditioning tank followed by a high shear mixer, floatation cell and pyrite separator (hydraulic or flume separator).

Hydraullc Classifier: a 4.75 liter vessel consisting of floatation, washing and settling zones. A DENVER D12 floatation machine is used in the floatation.

Flume Pyrtte Separator: a $110 \mathrm{~mm}$ wide and 700 $\mathrm{mm}$ long vessel with spival feeder (transfer) for the frother, and total holding capacity of 1.8 liters.

Slurry Tank: 1.5 liter capacity, acrylic tank, with 1/8 hp agitator.

Agglomeratlon Tank: 1.4 liter capacity, acrylic tank, with 1/8 hp agitator, and turtine impeller.

Utllitles: water, 2 liters per minute; electricity, 50 amp $110 \mathrm{~V}$.
Space: 10 square meters, with a floor track drainage systern.

The following sections describe the equipmemt used, the work performed and the design methods developed in the CPRU.

\subsection{CPRU Process Flowsheet}

Figures 4.1 and 4.2 present two CPRU process configurations. The unit includes the following major equipment.

- stumy conditioning tank

- high shear agglomeration tank

- floatation cell (or flume pyrite separator)

- mydraulic classitier

\subsubsection{Major Equipment and Instrumentation}

\section{Slurry Conditioning Tank}

The coal sturry conditioning tank is made of acrylic pipe with a conically shaped bottom and has a capacity of 1.49 liters at $1200 \mathrm{~mm}$. It has a $139 \mathrm{~mm}$ internal diameter and is $210 \mathrm{~mm}$ high. The tank is equipped with a mixer set. The mixer set has a 1/8 hp motor and one mixing ir peller.

High Shear Agglomeration Tank

The high shear tank has a capacity of 1.43 liters at $1750 \mathrm{pm}$, an inside diameter of $126 \mathrm{~mm}$, an inside depth of $206 \mathrm{~mm}$, and a centerline depth of $230 \mathrm{~mm}$. It is equipped with a 1/8 hp mixer with a turbine impeller.

\section{Floatation Cell}

The floatation cell has a working volume of about 2.75 liters at $100 \mathrm{~mm}$. The cell is equipped with a overflow weir device which controls the pulp level and extended froth retrieval paddles.

\section{Hydraullc Separator}

The hydraulic separator has a working volume of 4.75 liters at $1100 \mathrm{~mm}$ (Figure 4.3). The separator is cylindrical in shape and has three zones:

- Washing zone: The washing zone is rectangular in shape with a length of $104 \mathrm{~mm}$, a width of 85 $\mathrm{mm}$, and a depth of $103 \mathrm{~mm}$. The dimensional volume of the wash zone is about 1.1 liters, however, the zone is equipped with high penetration water wash nozzles and the working 


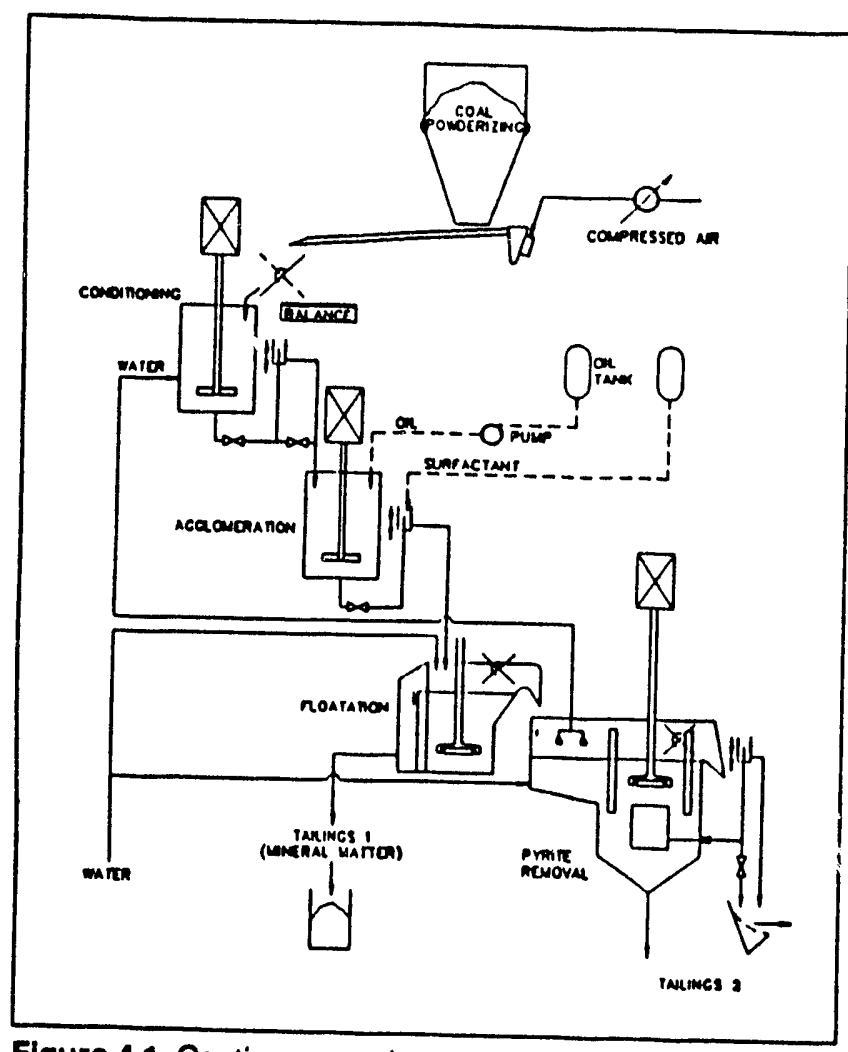

Figure 4.1. Continuous pyrite removal bench unit (system 1).

volume is expected to be lower. The water wash nozzles can operate in the 6 to $30 \mathrm{~kg} / \mathrm{h}$ range and they penetrate the troth about $50 \mathrm{~mm}$.

- Floatation zone: The fioatation zone is $140 \mathrm{~mm}$ in diameter, has a $149 \mathrm{~mm}$ depth and is equipped with long stationary baffles to dampen the axial motion of the floatation impeller within the settling zone. The baffles are $89 \mathrm{~mm}$ long and $12 \mathrm{~mm}$ wide. A DENVER Floatation Machine, Model D12, is used in the hydraulic separator and was equipped with a variable speed control, a rpm tachometer, and a self aeration impeller system. The approximate air input to the floatation cell is 1.4 liters/minute at $100 \mathrm{pm}$.

- Settling zone: The settling zone is $131 \mathrm{~mm}$ in depth. The flow stabilizer is cylindrical in shape with a diameter of $60 \mathrm{~mm}$, and an overall height of $88 \mathrm{~mm}$. The bottom of the settling zone is conical in shape at an angle of 30 degrees.

Details of the hydraulic separator are given in Figure 4.3.

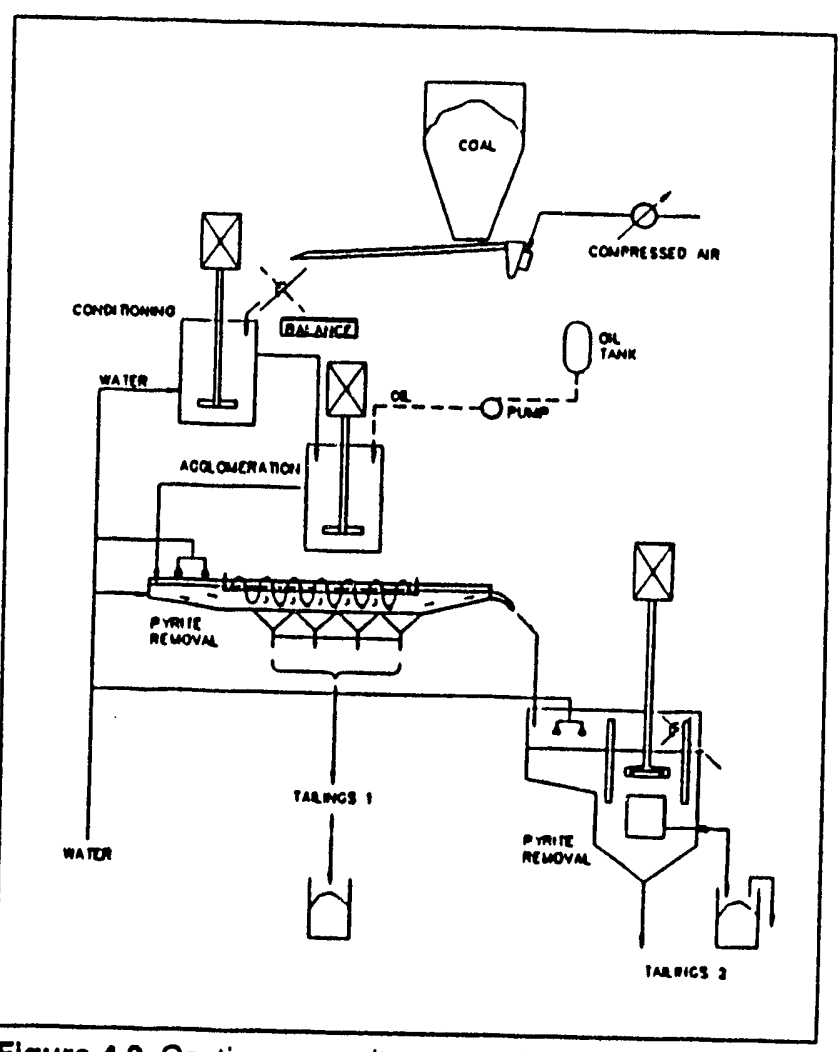

Figure 4.2. Continuous pyrite removal unit (system 2).

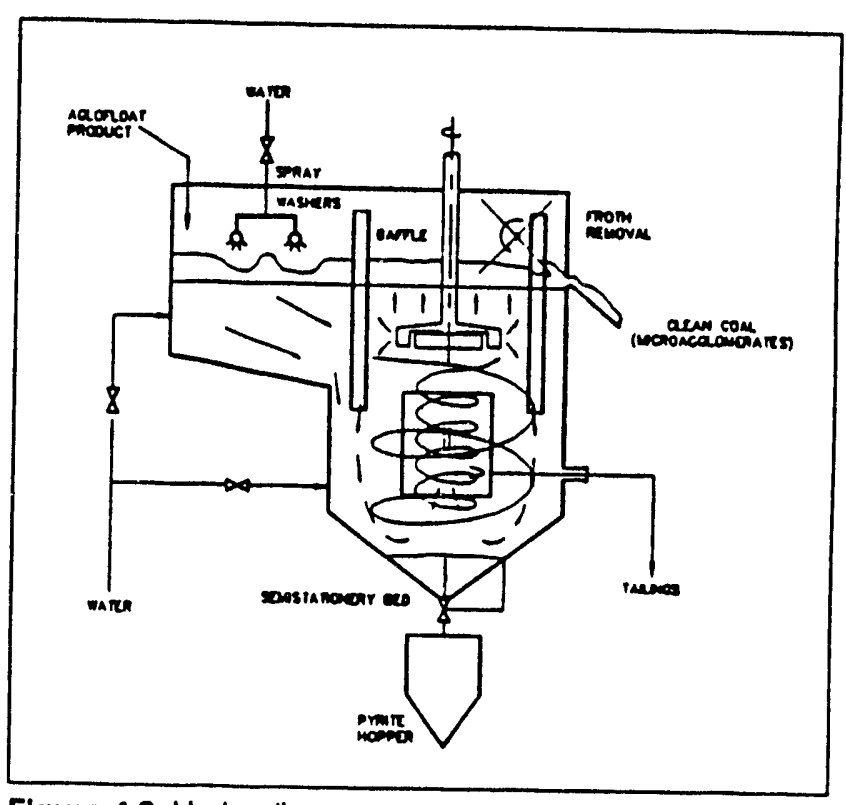

Figure 4.3. Hydraulic separator. 


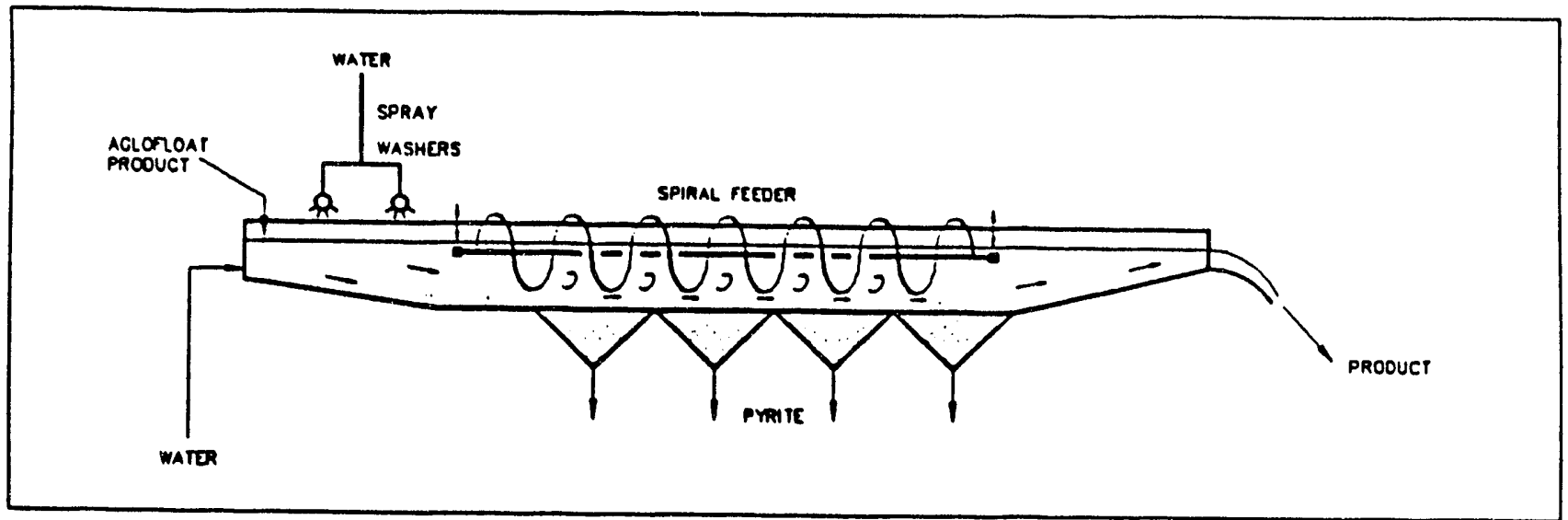

Figure 4.4. Flume separator.

\section{Flume Pyrlie Separator}

The separator acts as a replacement for the floatation cell (Figure 4.2). The separator is $110 \mathrm{~mm}$ wide and $700 \mathrm{~mm}$ long. It has a total holding capacity of 1.8 liters. The separator is equipped with a spiral feeder (transporter) powered by a 1/8 hp motor-gear assembly (Figure 4.4).

The equipment operates by means of water flow which carries the washed microagglomerates to the bend sieve. Pyrite particles are collected in four stationary bed cones from where they are removed with the tailings.

\subsection{CPRU Operating Experience and Optimization}

\subsubsection{Unit Commissioning and Results}

The pyrite removal from coal microagglomerates or floatation flocs was investigated in two process configurations, namely:

1. System 1 consisting of à floatation cell followed by a hydraulic classifier (Figure 4.1).

2. System 2 including a flume pyrite separator and a hydraulic classifier (Figure 4.2).

In the initial tests, both systems were evaluated for their performance, then the results of these tests were compared to standard washability lests performed by DOE and ARC using Upper Freeport bituminous coal with pyrite content of 2.17 percent. The results of the evaluation tests are presented in Figure 4.5. Performance of both systems is closely
Correlated with the washability curve which suggests that:

- The primary mechanism (selection) in operation is that of separation of pyrite from coal material due to the gravity difference between these materials.

- The effectiveness of the separation for both systems, approached the separation limit for the Upper Freeport coal as defined by the washability test.

- For the conditions studied, System 1 yielded higher coal recovery and higher sulphur content in the product than System 2; however, operations at lower coal recovery would reduce the coal recovery and sulphur level in the clean coal product to levels shown for System 2.

The commissioning of the unit was conducted over a period of several months. The major equipment modifications implemented were:

- A second high shear mixer was installed in series to enhance the oil the combustible solids contact, to reduce the oil dosage requirement, and to improve the overall combustibles recoveries.

- A second floatation cell was designed, labricated and installed in series with the floatation tailings to improve combustibles recoveries.

- Accumulation vessels were installed on both the floatation cells and the bench scale hydraulic separator to enhance the removal of sulphur and ash rich particles and to improve the repeatability of experimentation.

- A temperature controlled feed water source was installed to maintain higher system temperature, 
to improve oil dispersion and coavoil wetting within the high shear mixer.

Following the commissioning, the unit operated at its nominal capacity of $5 \mathrm{~kg} / \mathrm{hr}$ of feed coal. Typical results for System 1 for Upper Freeport and Ohio coals are presented in Table 4.1.

\subsubsection{Parametric Sludies for Systems 1 and 2}

Figures 4.1 and 4.2 present the two alternate pyrite removal process configurations studied (Systems 1 and 2). The major factors which varied in these studies were the coal feed rate and the bridging oil concentration. A summary of the completed test results follows.

\section{System 1}

Table 4.2 and Figure 4.6 depict the performance of System 1 for Upper Freeport bituminous coal using bitumen and diesel oil at a 2 to 3 weight ratio as bridging oil. The key conclusions and irends presented in Table 4.2 are:

- High combustible recoveries were obtained for the conditions studied, i.e., coal feed 2.16 to 5.14 $\mathrm{kg} / \mathrm{hr}$ and oil concentration 2.4 to 6.2 percent.

- Over the range of coal feed rates and oil concentrations above, the total sulphur removal ranged from 28 to 36 percent, pyrite sulphur removal ranged from 46 to 59 percent and inorganic sulphur removal (pyrite + sulphites, etc.) ranged from 50 to 62 percent.

- The majority of the pyrite was removed in the floatation and separation steps (Figure 4.6).

\section{System 2}

Performance of System 2 with the Upper Freeport coal is summarized in Table 4.2 and Figure 4.7. The major conchusions from the data presented are:

- The percentage of sulphur reduction for Upper Freeport coal ranged from 39 to 49 percent for total sulphur, 50 to 72 percent for pyritic sulphur and 64 to 70 percent for total inorganic sulphur.

- The larger percentage of sulphur removal in System 2 as contrasted with System 1 may be due to higher sulphur contents in the coal feed samples. This conjecture is supported by the fact that the sulphur content is higher (total and pyritic) in the product of System 2, than in the product of System 1.

Table 4.2 also presents, for comparison, deashing and desulphurization data for Upper Freeport coal

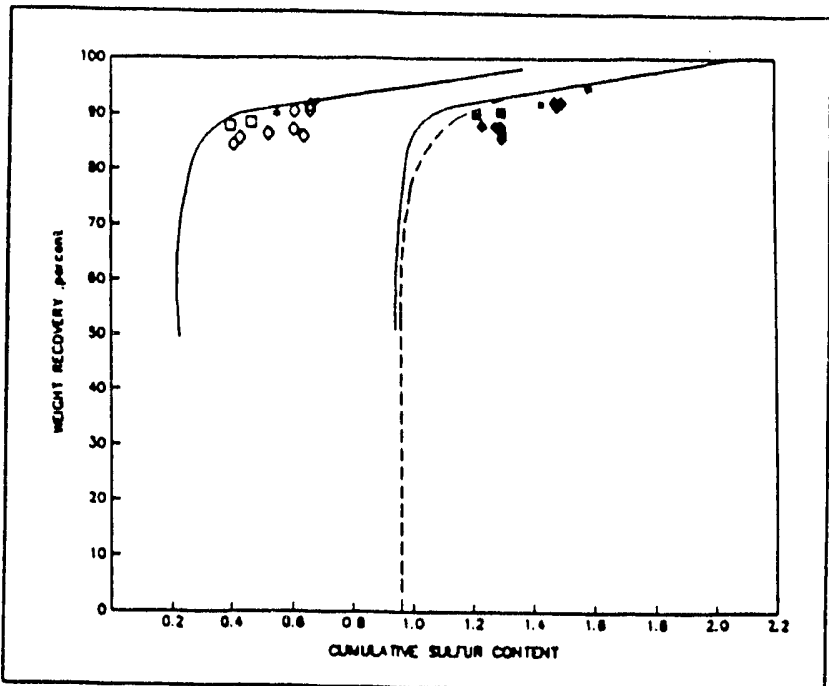

Figure 4.5. Cleaning of Upper Freeport coal by Aglofloal process in continuous pyrite separation unit ( $5 \mathrm{~kg} \mathrm{hr})$.

$\square$ syst 2, pyritic S; $\diamond$ syst 1, pyritic S; $>$ syst 1, total S;

a syst 2, total S; " batch test (single stage) - DOE wash. curves $\left(d_{50}=114 \mu \mathrm{m}\right)$; - ARC Wash. curves $\left(d_{50}=220 \mu \mathrm{m}\right)$.

Table 4.1. Pyrite removal in CPRU (System 1)a.

\begin{tabular}{|c|c|c|c|c|c|c|c|}
\hline \multirow{2}{*}{$\begin{array}{l}\text { Coal } \\
\text { Upper } \\
\text { Freeport }\end{array}$} & \multicolumn{2}{|c|}{$\begin{array}{l}\text { Foed } \\
\text { h Total } \\
\text { sulphur }\end{array}$} & $\begin{array}{c}\mathrm{Pr} \\
\text { Ash }\end{array}$ & $\begin{array}{l}\text { duct } \\
\text { Total } \\
\text { sulphur }\end{array}$ & \multicolumn{2}{|c|}{$\begin{array}{l}\text { Sulphu } \\
\text { removal, } \\
\text { Total Pyr. }\end{array}$} & $\begin{array}{l}\text { Ir } \\
\text { Inor. }\end{array}$ \\
\hline & 12.2 & 2.3 & 8.4 & 1.6 & 36 & 51 & 54 \\
\hline Ohio & 9.7 & 4.6 & 5.5 & 3.5 & 27 & 36 & 43 \\
\hline
\end{tabular}

a: Feed rate $-5 \mathrm{~kg} / \mathrm{hr}$, oil addition $-2 \%$

using the single-stage Aglofloat procedure in a batch mode. This comparison suggests that the deashing and desulphurization performance of Systems 1 and 2 is equal or better than that which could be expected from the single-stage Aglofloat process. Table 4.2 also compares the performance of the CPRU to single- and two-stage batch processes. As indicated by the product properties, CPRU pertormance falls between the single- and two-stage processes.

Table 4.3 presents additional Aglofloat data for an equipment configuration which bypasses the floata. tion step and, therefore, indirectly indicates the importance and impact of the floatation step on the overall circuit performance in System 1. Comparison of the results in Table 4.3 for tests C. 6 and C.7 with the results of the reference test C-5, suggests that 


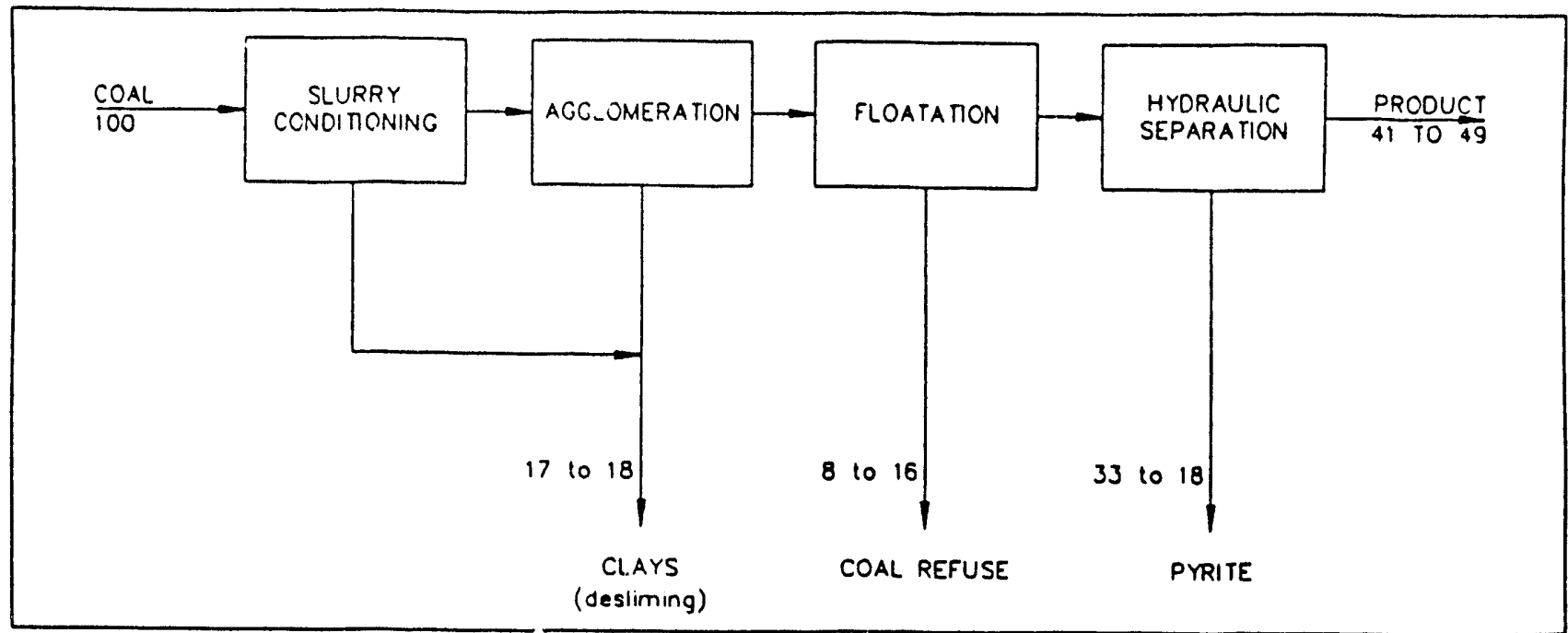

Flgure 4.6. Overall material balance for pyrite removal for system 1 (Runs C-3 and C-5).

removal of $1 / 2$ to $1 / 3$ of the pyritic sulphur is possible during floatation and that this step is an important unit operation in the overall system (System 1). Bypassing the floatation cell not only decreases the overall pyrite removal but also reduces the performance of the hydraulic separator (Figure 4.8).

\subsubsection{Steady-State Studies with Illinois \#6 Coal} A series of tests was performed, using Illinois \#6 coal, to establish the repeatability of the CPRU .results and to evaluate steady-state operation of System 1. It was also felt that the combustibles recovery and the amount of bridging oil required could be improved by further refinement of the CPRU.

Figures 4.9 to 4.11 show the effect of variation in bridging oil addition in the range of 2.0 to 3.0 percent (dry coal basis) on combustible recovery, and total sulphur and pyrite sulphur in the products collected from the hydraulic separator. The key conclusions from these experiments were:

- For the oil concentration range studied, oil concentration did not influence the amount of combustibles recovered (Figure 4.9).

Table 4.2. Cleaning of Upper Freeport coal in continuous pyrite separation unit.

\begin{tabular}{|c|c|c|c|c|c|c|c|c|c|c|c|}
\hline \multirow[b]{2}{*}{ Test } & \multirow[b]{2}{*}{$\begin{array}{c}\text { Coal } \\
\text { cap. } \\
\text { (kg/hr) }\end{array}$} & \multirow[b]{2}{*}{$\begin{array}{l}\text { Oll } \\
\text { add. } \\
(\%)\end{array}$} & \multicolumn{2}{|c|}{ Inlilal Coal } & \multicolumn{3}{|c|}{ Product } & \multicolumn{3}{|c|}{ Sulphur reduction } & \multirow[b]{2}{*}{$\begin{array}{c}\text { Recov. } \\
\text { (\%) }\end{array}$} \\
\hline & & & $\begin{array}{l}\text { Ash } \\
(\%)\end{array}$ & $\begin{array}{c}\text { Total S } \\
(\%)\end{array}$ & $\begin{array}{l}\text { Ash } \\
(\%)\end{array}$ & $\begin{array}{c}\text { Total } \mathbf{S} \\
(\%)\end{array}$ & $\begin{array}{l}\text { Pyr. } \\
(\%)\end{array}$ & $\begin{array}{c}\text { Total } \\
(\%)\end{array}$ & $\begin{array}{l}\text { Pyr. } \\
(\%)\end{array}$ & $\begin{array}{c}\text { Inorg. } \\
(\%)\end{array}$ & \\
\hline $\begin{array}{l}\text { System 1 } \\
\text { C-2 } \\
\text { C-3 } \\
\text { C-4 } \\
\text { C.5 } \\
\text { System 2 }\end{array}$ & $\begin{array}{l}3.8 \\
4.6 \\
2.16 \\
5.14\end{array}$ & $\begin{array}{l}2.2 \\
1.9 \\
6.2 \\
2.4\end{array}$ & $\begin{array}{l}13.0 \\
13.0 \\
12.2 \\
12.2\end{array}$ & $\begin{array}{l}2.17 \\
2.17 \\
2.30 \\
2.30\end{array}$ & $\begin{array}{l}8.2 \\
8.5 \\
9.5 \\
8.4\end{array}$ & $\begin{array}{l}1.57 \\
1.54 \\
1.70 \\
1.55\end{array}$ & $\begin{array}{l}0.67 \\
0.61 \\
0.72 \\
0.67\end{array}$ & $\begin{array}{l}32 \\
33 \\
28 \\
36\end{array}$ & $\begin{array}{l}52 \\
59 \\
46 \\
51\end{array}$ & $\begin{array}{l}58 \\
62 \\
50 \\
54\end{array}$ & $\begin{array}{l}94 \\
95\end{array}$ \\
\hline $\begin{array}{l}\text { C.21 } \\
\text { C.22 } \\
\text { Batch System }\end{array}$ & $\begin{array}{l}5.37 \\
5.85\end{array}$ & $\begin{array}{l}2.20 \\
2.38\end{array}$ & $\begin{array}{l}16.5 \\
16.5\end{array}$ & $\begin{array}{l}2.27 \\
2.27\end{array}$ & $\begin{array}{l}9.6 \\
9.5\end{array}$ & $\begin{array}{r}1.36 \\
-1.26\end{array}$ & $\begin{array}{l}0.47 \\
0.39\end{array}$ & $\begin{array}{l}44 \\
49\end{array}$ & $\begin{array}{l}62 \\
69\end{array}$ & $\begin{array}{l}64 \\
70\end{array}$ & $\begin{array}{l}92 \\
92\end{array}$ \\
\hline $\begin{array}{l}\text { Aglofbat } \\
\text { Single-Stage }\end{array}$ & - & $\begin{array}{l}2.0 \\
0.6\end{array}$ & $\begin{array}{l}12.3 \\
12.3\end{array}$ & $\begin{array}{l}2.33 \\
2.33\end{array}$ & $\begin{array}{l}8.4 \\
9.2\end{array}$ & $\begin{array}{l}1.49 \\
1.65\end{array}$ & - & $\begin{array}{c}40.9 \\
34\end{array}$ & $\begin{array}{l}60 \\
-\end{array}$ & $\begin{array}{l}64 \\
52\end{array}$ & $\begin{array}{c}94 \\
97.4\end{array}$ \\
\hline
\end{tabular}

Note: All values on dry basis. Bitumen and diesel oil in 2:3 ratio. Feed particle size the same for batch and continuous tests (dso approx. 220um). 


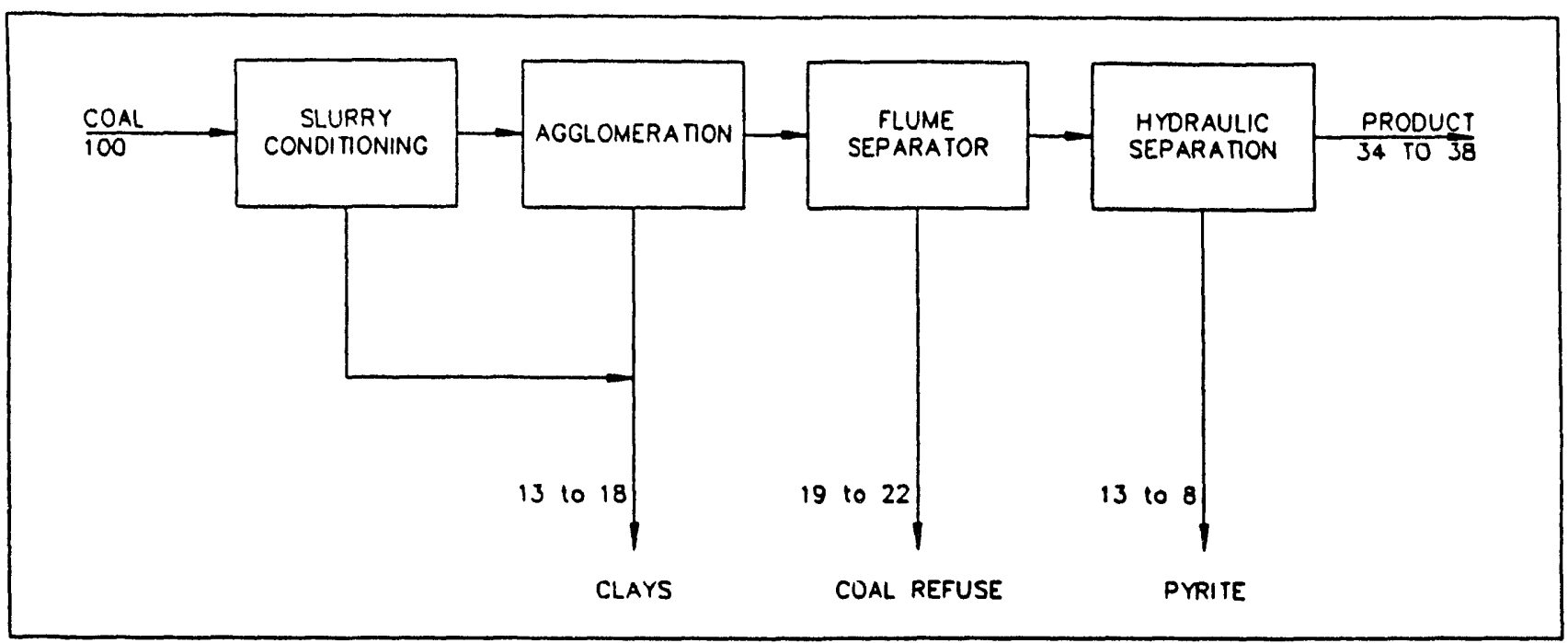

Figure 4.7. Overall material balance for pyrite removal system with flume separator.

- Total sulphur in agglomerates also was not influenced by an increase in bridging oil concentration (Figure 4.10).

- The pyritic sulphur content in agglomerates was influenced more by a non-controlled operating parameter than by the change in oil concentration, as indicated by the wide scatter of the data.

A second series of tests was carried out on System 1 with Illinois No. 6 ROM coal to study the effect of hydroseparator operating parameters on agglomerate product properties. Detailed data for these tests are presented in Appendix 2, Tables A2.1 to A2.5. These data are summarized in Figures 4.12 10 4.14. The key conclusions depicted are:
- CPRU was capable of recovering over 75 percent of combustibles with sulphur reduction of about $35 \%$ (Figure 4.12).

- CPRU product had a reduced pyritic sulphur content ( -1.3 percent, w/w dry basis) at combustibles recovery of over 75 ,ercent (Figure 4.13).

- CPRU ash washability curve (Figure 4.14) showed somewhat lower combustibles recovery than for standard washability curves, with the same ash content in the product.

Talsle 4.3. Cleaning of Upper Freeport coal in continuous pyrite separation unit.

\begin{tabular}{|c|c|c|c|c|c|c|c|c|c|c|c|}
\hline \multirow[b]{2}{*}{ Test } & \multirow{2}{*}{$\begin{array}{c}\text { Coal } \\
\text { cap. } \\
\text { (kg/hr) }\end{array}$} & \multirow{2}{*}{$\begin{array}{l}\text { Ol1 } \\
\text { add. } \\
(\%)\end{array}$} & \multicolumn{2}{|c|}{ Initlal coal } & \multicolumn{3}{|c|}{ Product } & \multicolumn{3}{|c|}{ Sulphur reduction } & \multirow[b]{2}{*}{$\begin{array}{c}\text { Recovery } \\
\text { (\%) }\end{array}$} \\
\hline & & & $\begin{array}{c}\text { Ash } \\
(\%)\end{array}$ & $\begin{array}{c}\text { Total S } \\
(\%)\end{array}$ & $\begin{array}{l}\text { Ash } \\
(\%)\end{array}$ & $\begin{array}{c}\text { Total } 5 \\
(\%)\end{array}$ & $\begin{array}{l}\text { Pyr. } \\
(\%)\end{array}$ & $\begin{array}{l}\text { Total } \\
(\%)\end{array}$ & $\begin{array}{l}\text { Pyr. } \\
\text { (\%) }\end{array}$ & $\begin{array}{c}\text { Inorg. } \\
(\%)\end{array}$ & \\
\hline C.5 (Rof) & 5.14 & 2.4 & 12.2 & 2.30 & 8.4 & 1.55 & 0.67 & 36 & 51 & 54 & 95 \\
\hline C-6 & 5.34 & 2.28 & 12.3 & 2.06 & 9.0 & 1.58 & 0.77 & 26 & 37 & 43 & $\begin{array}{l}\text { Floatation } \\
\text { step bypassed }\end{array}$ \\
\hline C-7 & 5.34 & 2.28 & 12.3 & 2.06 & 9.6 & 1.75 & 0.91 & 18 & 26 & 33 & $\begin{array}{l}\text { Floatation } \\
\text { step bypassed } \\
\text { \& sprinkling } \\
\text { discontinued. }\end{array}$ \\
\hline
\end{tabular}

Nete: All values on dry basis. Bitumen and diesel oil in 2:3 ratio. Feed particle size the same for batch and continuous tests (dso approx. $220 \mu \mathrm{m}$ ). 


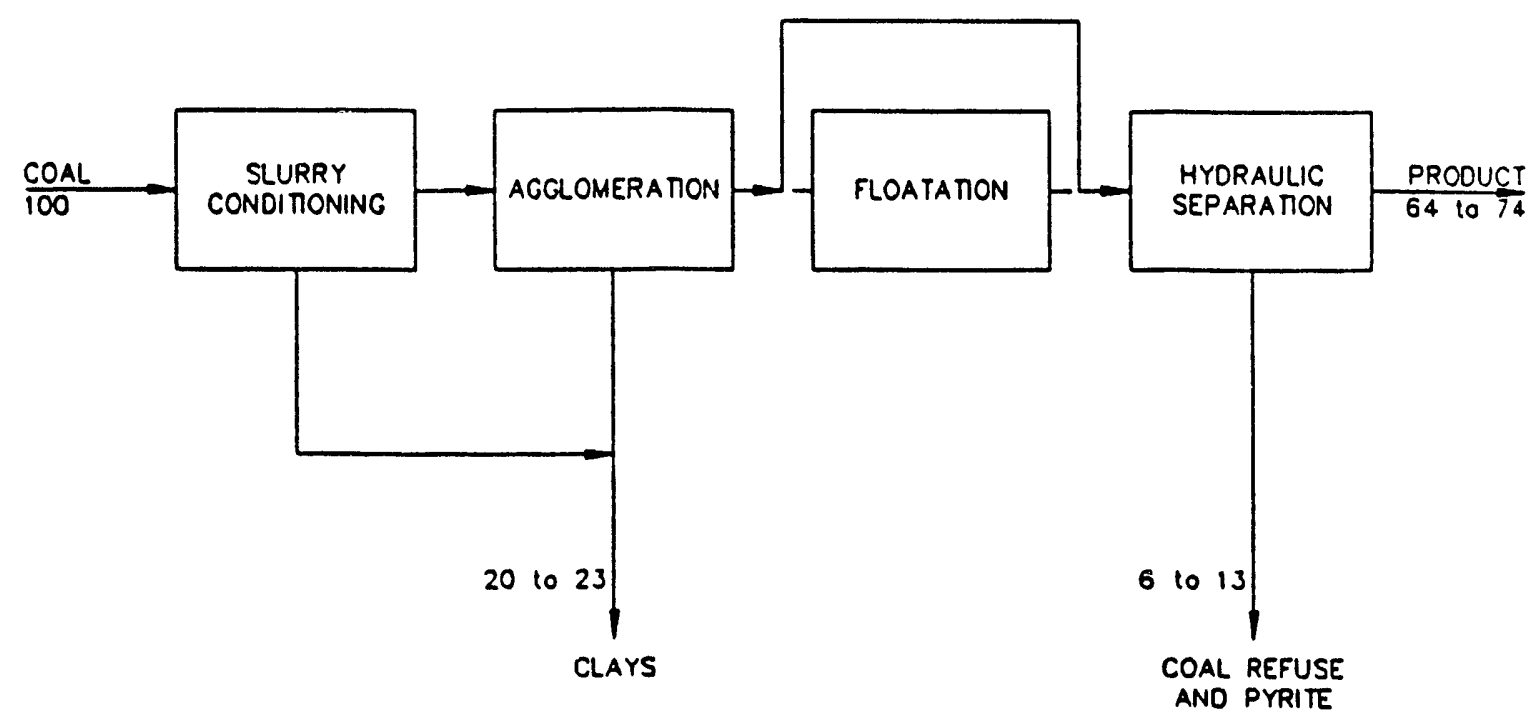

Figure 4.8. Overall material balance for pyrite removal in systems with bypassed floatation step (Runs C-6 and C-7).

The tests completed provided a basis for scale-up of the hydraulic separator for the large pibt plants (IATF).

\subsubsection{Scale-up of the Hydraulic Separator}

The design used for the scale-up of the hydraulic separator subdivided the separator vessel into three zones: the floatation zone, the settling zone and the

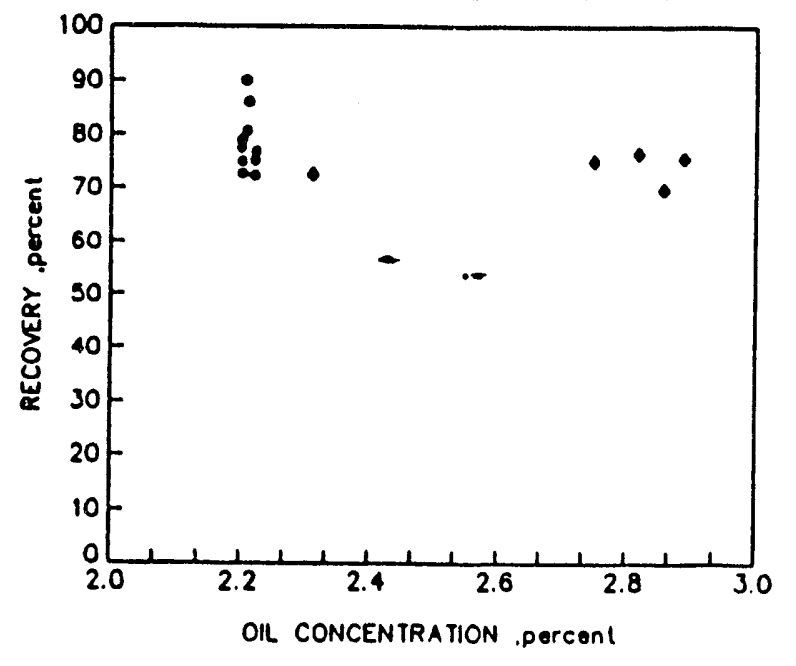

Flgure 4.9. Effect of oil concentration on combustible matter recovery. Runs 6, 7, and 8; $\bullet$ Runs 3 and 4 . washing zone (Figure 4.15). The procedures used in the design of each zone are described below:

\section{Floatation Zone}

The scale-up procedure for the design of the floatation zone used kinetic test data for floatation of microagglomerates and empirical correlations derived from manufacturers' designs for floatation

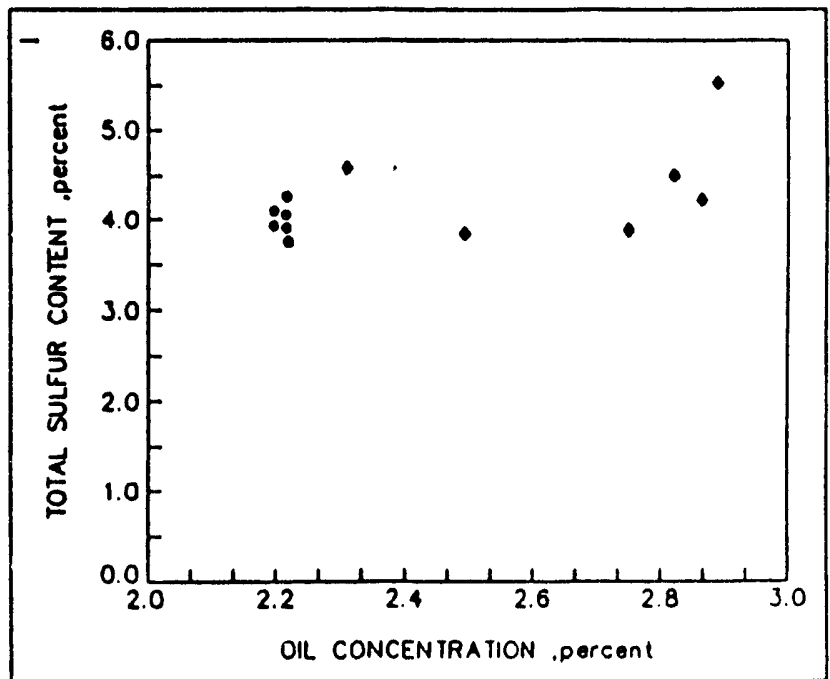

Figure 4.10. EHect of oil concentration on total sulphur content. Runs 6, 7, and 8; Runs 3 and 4. 


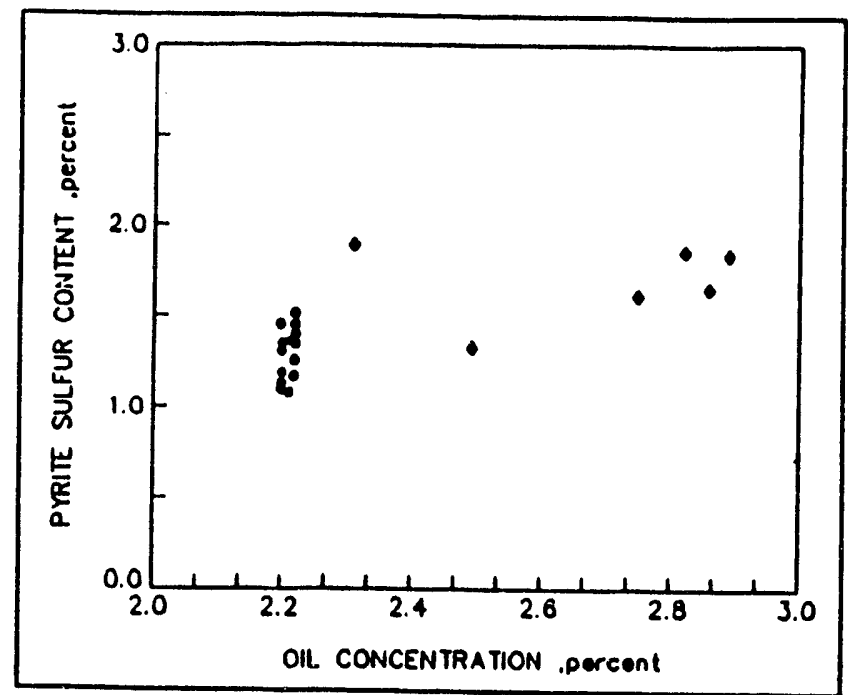

Figure 4.11. Effect of oil concentration on sulphur content. Runs 6, 7, and 8; Runs 3 and 4.

cell geometry and impeller dimensions. Specitic design parameters used were:

- Floatation ilme required: derived irom the floatation kinetics tests data for Illinois $\$ 6$ coal (Figure A3.1 in Appendix 3).

- Floatation zone volume requirement: calculated from slumy feed rate, solid loading and density.

- Volumetric safety factor: estimated at 25 percent of the floatation volume.

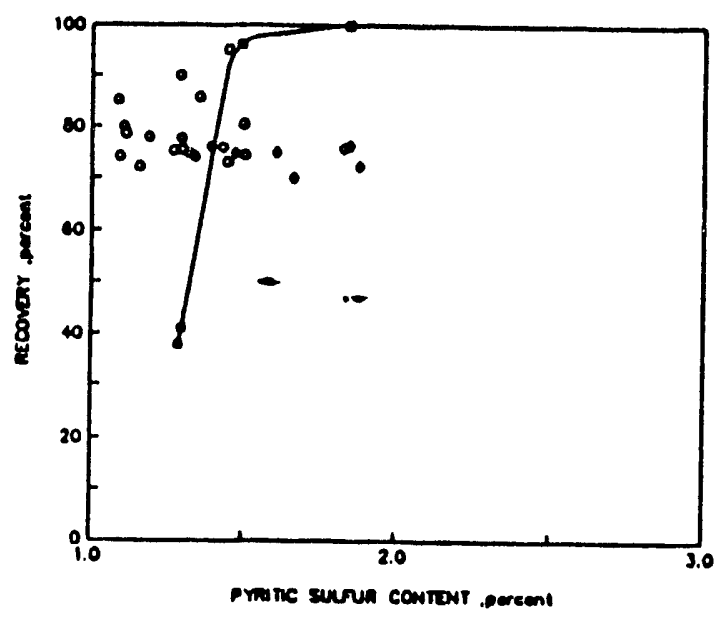

Figure 4.13. Pyrite washability curve for lllinois $6 \mathrm{coal}$. 0 Runs 6, 7, and 8; $\triangle$ Runs 3 and 4; $\square$ wash pyrite $d_{23}=150 \mu \mathrm{m}$.

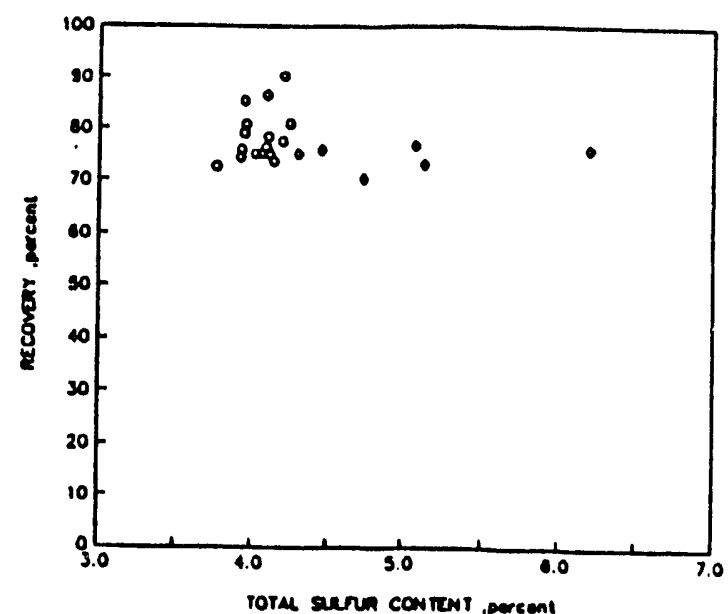

Floure 4.12. Total sulphur washability curve for llinois 8 coal. O Runs 6, 7, ano 8; 0 Runs 3 and 4.

- Geometric cell configuration: calculated from an empirical relationship between cell volume and cell depth based on manufacturers' data (Figure A3.2 in Appendix 3).

Based on the design calculations, the floatation zone for the IATF hydraulic separator is cylindrical in shape with a depth of $432 \mathrm{~mm}$ and a diameter of $508 \mathrm{~mm}$. The discharge paddle assembly has a steep angle of 60 degrees to allow unobstructed

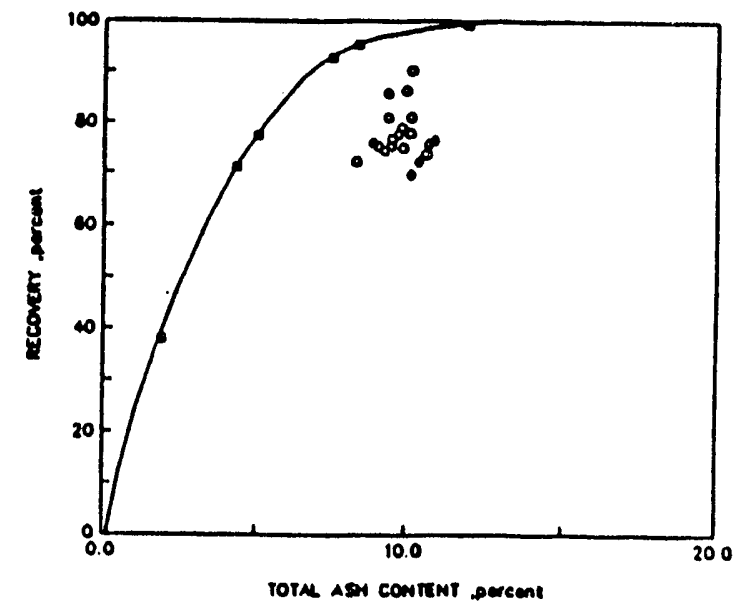

Flgure 4.14. Ash washability curvo for llinois $6 \mathrm{coal}$. O Runs 6, 7, and 8; $O$ Runs 3 and 4; $\square$ wash pyrite $d_{23}=150 \mu \mathrm{m}$. 
drainage of water and sulphur/ash rich particles. The width of the discharge trough is $356 \mathrm{~mm}$. The impeller is $254 \mathrm{~mm}$ in diameter and can be positioned over a range of depths.

\section{Setting Zone}

The settling zone was defined by three regions: the spiral settling region, the bed washing region, and the vortex region (Figure 4.15). The critical parameters defined in the design were:

- Geometrle constralnts: zone diameter, depth and angle of the conical shaped bottom.

- Veloclty assumptions: critical velocities for each region plus velocity at the interface of the settling and floatation zone.

- Flow baffles: designed to achieve the required velocities within each region.

Based on the design calculations, the settling zone for the IATF is $508 \mathrm{~mm}$ in diameter and 432 $\mathrm{mm}$ in depth. It is equipped with a conical shaped bottom with a $\mathbf{3 0}$ degree angle to allow continuous removal of solids and to stabilize a semi-stationary solids bed. The flow stabilizer is $321 \mathrm{~mm}$ in diameter, $271 \mathrm{~mm}$ in height and is positioned 120 $\mathrm{mm}$ from the bottom of the floatation zone. The batfles are $100 \mathrm{~mm}$ in wioth, tapered at the center of the settling zone, and cut short of the flow stabilizer so as not to protrude into the vortex region.

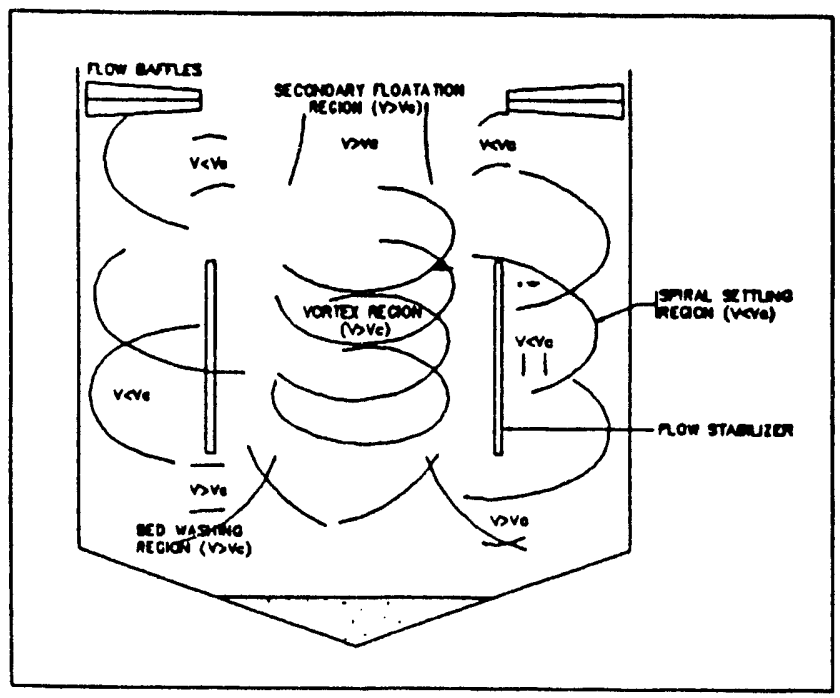

Figure 4.15. Settling zone velocity contiguration.

\section{Washing Zone}

The design of the washing zone was based on the following constraints:

- Maximum zone depth: defined by the floatation zone depth and location of the communication region between the three zones.

- Incline of the washing zone: a 32 degree angle to the horizontal was selected.

- Surface area ratlo: between the floatation and the washing $z \mathrm{C}$ ne, based on the CPRU.

- Froth communication ratlo: the CPRU froth communication ratio between the floatation and washing zone was maintained.

\subsection{Conclusions}

Studies of coal cleaning performed with Systems 1 and 2 indicated promising results for both systems. Both unit processes showed reduction of pyrite in the agglomerates; however, the flume separator was found to be more operationally complex than the floatation cell. As a result, System 1, including the floatation ceil and hydraulic separator was selected for the Aglofloat process configuration.

The experiments conducted with high sulphur IIlinois No. 6 coal indicated that at best conditions obtained, the combustibles recovery ranged from 75 to 80 percent, the total sulphur reduction ranged from 50 to 55 percent, the pyritic sulphur reduction ranged from 72 to 77 percent, and the ash reduction ranged from 82 to 86 percent.

The operating parameters identified as important for optimization of the process were:

- oil concentration.

- Irother concentration.

- high shear mixing speed.

- high shear mixing time.

- size of the coal.

- solid loading in floatation cell.

The floatation cell removed about $65 \%$ of pyritic sulphur while the hydraulic separator was responsible for removing the remaining $35 \%$ of pyritic sulphur.

Specitic operational issues found with the CPRU were:

- Sufficient wash water volume and froth penetration with the wash zone of the hydraulic separator were required for the separator to function properly. 
- Tests conducted indicate that approximately 15 percent and 8 percent of the tolal combustble matter is lost in the floatation cell and hydraulic separator, respectively.

- Athough the CPRU demonstrated good repeatability of the product qually, accumulation within the system appeared to influence the product quality as the time of the run was extended. Hence, it is recommended that units constructed in the future inctude some means of removing the accumulated solids.

The CPRU was successtully used for the scale-up of the hydraulic separator for the lange pibt plant (IATF). Desion procectures developed will be further used to improve the mydroseparator in the IATF. 


\subsection{IATF Design for the Aglofloat Process}

The overall objective of the IATF was to conduct process research \& engineering studies on:

- beneficiation of low rank coal by deashing and moisture reduction (the Agflotherm process);

- desulphurization of bituminous $\infty$ al through pyrite removal (the Aglofloat process); and

- the cleaning of hydrocartons from contaminated soils (the HC Clean Soil process).

For each of these processes, the IATF was used

to:

- verity the developed agglomeration processes in the smallest possible continuous unit;

- identify the factors which would be used in scaling-up the process for commercialization;

- obtain engineering and operation data required for process evaluation and large plant development; and

- develop process control philosophy.

\subsubsection{IATF Design Specifications}

The IATF included all major equipment in flowsheet configurations studied in the Aglofloat process. The exceptions were equipment needed for the primary and secondary crushing of coal.

The nominal IATF design specifications were as follows:

Maximum Plant Capacity: $250 \mathrm{~kg}$ h of coal treated.

Process Conflguration: various flowsheet configura-tions as required in process optimization research.

Coal Grinding System: $250 \mathrm{~kg} / \mathrm{h}$; feed coal top size $-10 \mathrm{~mm}$; pulverized size variable.

Agglomeration Section: high shear mixer, 58 liters capacity, with 4 minutes mean residence time; bw shear mixer, 500 liters capacity, with 26 minutes mean residence time; total slumy flow -750 to 950 $\mathrm{kg} / \mathrm{h}$.

Floatation Cells: $410 \mathrm{~kg} / \mathrm{h}$ of froth.

Hydroseparator: $400 \mathrm{~kg} / \mathrm{h}$ of froth.

Floor Space: three levels, 63 square meters each.
Utiltiles: water, 2.5 tonnes per hour electricity, 120 amp, $575 \mathrm{~V}$.

Plant Operation: 8 to 10 hour test periods extended up to 72 hours.

Equipmem: waterpiool, electrical enclosures meeting NEMA 12 standand or equivalent.

The following sections describe the equipment used, the work performed and the design methods developed in the IATF.

\subsubsection{IATF Flowshed}

Reterence flowsheet "ARC55 presents the IATF contiguration for the Agbofbat process. The facilities make possible the following unit operations:

- coal grinding and stumy preparation.

- oil preparation,

- microagolomeration,

- fbatation.

- pyrite removal,

- macroagglomeration,

- separation.

- waste treatment, and

- process control.

\subsubsection{Major Equipment and instrumentation}

A detailed description of the remaining equipment of the IATF is inctuded in Section 4, Volume 1 of this report. The following summarizes only the key equipment used in different IATF sections.

Coal Grinding and Slumy Preparation: This section comtains a coal hopper and feeder system, a rod-mill a vibrating Derrick coal screen, a coal sturry preparation tank, a drum tipper, a sump pump and two water storage tanks.

Oll Preparation: The system inctudes an electrically heated and agitated oil-mixing vessel, a hoist and crane for receipt of heavy oil and solvent drums, and an oil pump.

Microsgglomeration: Equipment in the microagglomeration section consists of two 58 liter, 4 minute residence time high shear mixers, and a sump pump. 


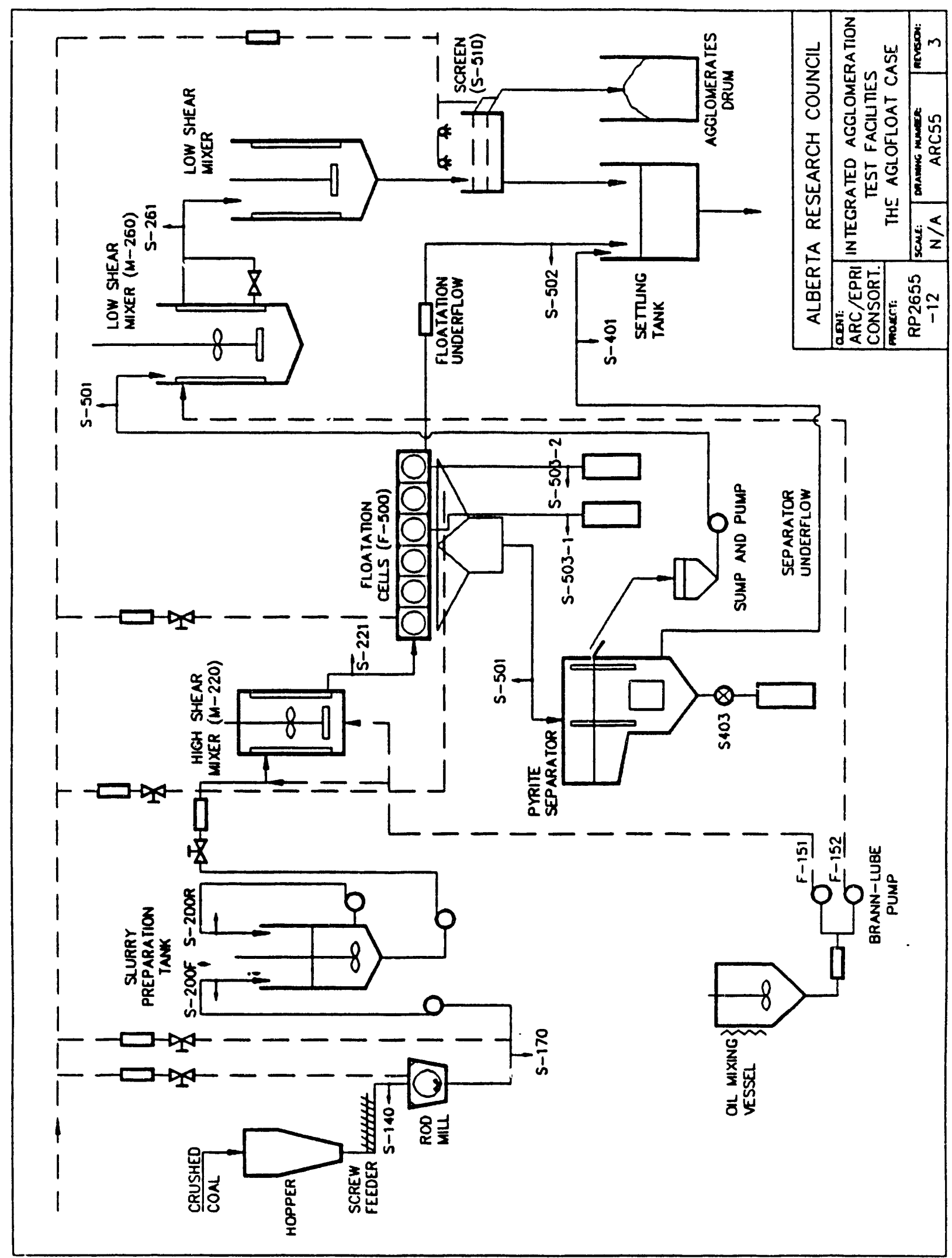


Floatation: A DENVER SUb-A floatation cell is used in the floatation section.

Pyrite Separation: Pyrite separation equipment developed by ARC, with sump pump.

Macroagglomeration: This section has two low shear mixers with 25 to 50 minutes residence time.

Separation: A double-decker drain and rinse screen, a tailings tank and a microagglomerates receiving drum, are used in the separation section.

Waste Treatment Section: Equipment in the waste treatment section consists of a settling tank, a skimmer for removal of solids, and a bag fitter in the recycle water line.

\section{Instrumentation}

The IATF has the following instrumentation and sampling points in support of the Aglofloat process studies:

- twelve slurry water sampling points, as indicated on reference flowsheet \#ARC55.

- temperature measurement sensors: two $K$-thermocouples per each mixer, one thermocouple in the oil tank.

- flow measurement sensors, to monitor the flow of rod-mill water to monitor slurry flow.

Descriptions of the sampling poirts, their locations, the sizes of the samples taken and the types of analyses performed are given in Table 5.1. The rationale for and objectives of the sampling and measurement instrumentation are discussed in detail in Volume 1, Section 4 of this report.

The key steps to process control and optimization of the Aglofloat process were:

- measurement and control of the feed rate and size distribution in the slurpy preparation tank;

- flow rate measuremem of the bridging oil feed to the high and low shear mixers;

- measurement and control of the bridging oil to coal ratio and measurement of the solid concentration in the high shear mixer;

- measurement and control of the slurry flow rate; and

- measurement of slurry solid concentration and the bridging oil in the low shear mixer.

The process control requirements described above were difficult to implement because the theol- ogy of the agglomerate slurry in the mixers is quite different from the rheology of coal-water slumies. At higher solids concentration, the agglomerate slurries are non-Newtonian, and it was difficult to ensure the target solid concentration in ine mixers just by adjustment of the coal slurry input. For a more accurate measurement and adjustment of the solids concentration ratio in the high and low shear vessels, nuclear density meters were installed on the feed lines; however, in-situ measurement of the solids concentration in the vessels would still be desirable.

\section{Process Control}

The IATF's process control and data acquisition hardware includes:

1. SAFE 8000 PC 8253 Process Control Computer.

2. TWo IBM PS/2 Computers.

3. VAX 6800 for data base management and reporting.

The IATF's process control hardware is run by a distributed control system DMACS (Distributed Manufacturing and Automatic Control Software) using an IBM ETHERNET network. The architecture of the controi system provides for all the :-quired data acquisition and process control including facilities for building interactive process schematics. Other syrtem functions and capabilities include:

- Visual indication of equipment status, process operating parameters, etc., using the process draw facility in DMACS.

- PID control blocks and on-line process calculations using PID calculation blocks.

- Data analysis program including analysis of trends, statistical analysis of collected data, flagging of the alarms, etc.

\subsubsection{Plant Safety and Environmental Issues}

A risk assessment was conducted tor the IATF to identify potential safety hazards in the plant. In general, the plant operation was classed as relatively low risk since it involves low temperatures and pressures and hydrocarbons with low volatility. Exceptions to this general classification were:

- the generation of coal dust in the coal grinding area, and

- potential equipment hazards such as sparking in the fan handling dust, high noise levels, siaff being caught in drives or bumt by hot equipment, etc. 
Table 5.1. Sampling and analyses.

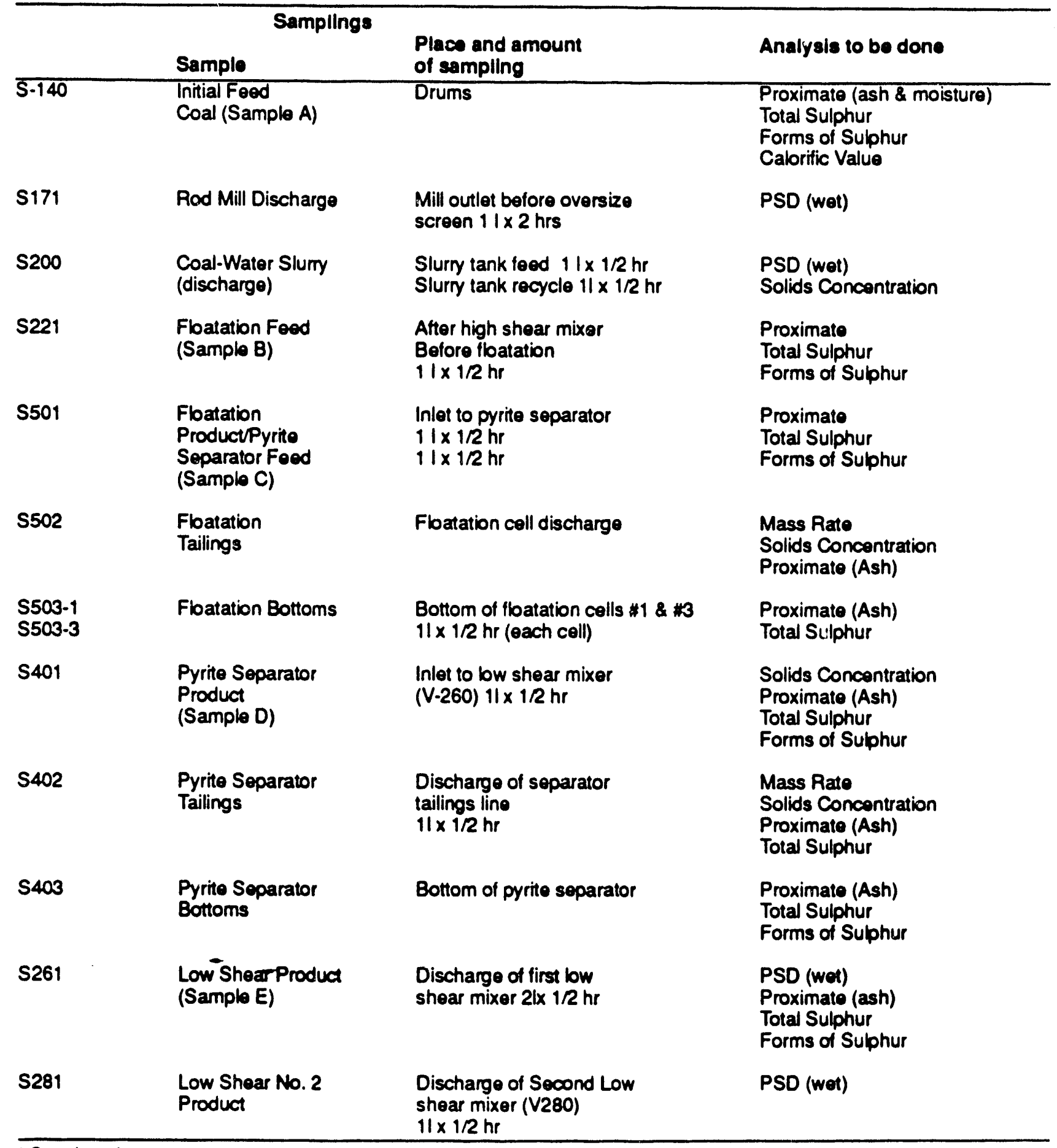

- Samples taken overy hour at steady-stage conditions 
Table 5.2. Cleaning of llinois coal in lATF unit (system without pyrite separator).

\begin{tabular}{|c|c|c|c|c|c|c|c|c|c|c|c|c|}
\hline \multirow[b]{2}{*}{ Teat } & \multirow{2}{*}{$\begin{array}{l}\text { Coal } \\
\text { through. } \\
(\mathrm{kg} / \mathrm{h})\end{array}$} & \multirow{2}{*}{$\begin{array}{l}\text { Oll } \\
\text { Add. } \\
(\%)\end{array}$} & \multicolumn{2}{|c|}{$\begin{array}{l}\text { Initial Coal } \\
\text { Total }\end{array}$} & \multicolumn{2}{|c|}{$\begin{array}{l}\text { Froth } \\
\text { Tot }\end{array}$} & \multicolumn{2}{|c|}{$\begin{array}{l}\text { Sulphur } \\
\text { Roduction }\end{array}$} & \multicolumn{2}{|c|}{$\begin{array}{l}\text { Product } \\
\text { (Agglom.) } \\
\text { Total }\end{array}$} & \multicolumn{2}{|c|}{$\begin{array}{l}\text { Sulphur } \\
\text { Roduction }\end{array}$} \\
\hline & & & $\begin{array}{l}\text { Ash } \\
(\%)\end{array}$ & $\begin{array}{c}\text { sulph. } \\
(\%)\end{array}$ & $\begin{array}{l}\text { Ash } \\
(\%)\end{array}$ & $\begin{array}{c}\text { sulph. } \\
(\%)\end{array}$ & $\begin{array}{c}\text { Total } \\
(\%)\end{array}$ & $\begin{array}{c}\text { Inorg. } \\
(\%)\end{array}$ & $\begin{array}{l}\text { Ash } \\
(\%)\end{array}$ & $\begin{array}{l}\text { sulph. } \\
(\%)\end{array}$ & $\begin{array}{c}\text { Total } \\
(\%)\end{array}$ & $\begin{array}{c}\text { Inorg. } \\
(\%)\end{array}$ \\
\hline Run 1 & 258 & $2.3+11.0$ & 25 & 2.8 & $\begin{array}{l}11.6 \\
11.8\end{array}$ & $\begin{array}{l}1.97 \\
2.32\end{array}$ & 34 & 46 & $\begin{array}{l}7.8 \\
8.0\end{array}$ & $\begin{array}{l}2.15 \\
1.98\end{array}$ & 40 & 59 \\
\hline Run 2 & 228 & $2.5+14.5$ & $\begin{array}{l}35.4 \\
33.6 \\
32.5\end{array}$ & $\begin{array}{l}4.34 \\
4.59 \\
4.70\end{array}$ & $\begin{array}{l}16.3 \\
14.3 \\
18.4\end{array}$ & $\begin{array}{l}4.61 \\
4.24 \\
4.63\end{array}$ & 20 & 37 & 9.3 & 4.62 & 22 & 49 \\
\hline Run 5 & 270 & $3.2+7.15$ & 30.8 & 5.10 & 17.5 & 4.50 & 26 & 33 & 10.6 & 4.51 & 31 & 48 \\
\hline $\begin{array}{l}\text { C-16 } \\
\text { Sys. } 1\end{array}$ & 1.83 & 3 & 34.8 & 4.82 & - & - & - & - & 8.8 & 3.9 & 42 & 71 \\
\hline $\begin{array}{l}1 \text { Stage } \\
\text { Batch }\end{array}$ & - & 0.6 & 34.8 & 4.82 & 11.7 & 4.29 & - & - & - & - & 39 & 52 \\
\hline
\end{tabular}

- All values of ash and sultur on dry basis.

These potential hazards were reduced by installation of a non-sparking fan for handling dust, installation of guards for all rotating equipment, and insulation of hot pipes and equipment. Special enclosures were installed around rod-mills to reduce noise. The protective measures taken, the equipment installed and the environmental review conducted are described in detail in Section 4 of Volume 1.

\subsection{Plant Operating Experience and Optimization}

\subsubsection{Plant Commissioning and Results}

Commissioning of the IATF for the Aglofloat Process started on May 9, 1989, with the processing of IIlinois No. 6 coal. The commissioning tests included three runs (\#1,2 and 5). These uns are depicted in Table 5.2 together with the results from the benchscale pyrite removal unit and batch-tests for comparison. The variations in key process parameters for these tests are presented in Figures A4.1 and A4.2 in Appendix 4. In general, the total and the inorganic sulphur removed in the IATF compared well with single-stage batch tests but was below the results obtained in the CPRU (Table 5.2).

Following the test runs \#1,2, and 5, commissioning tests were conducted to obtain 6 to 7 tonnes of agglomerates using Ohio coal. The tests were suc- cessfully conducted for 96 hours producing 54 drums of low ash ( 6 percent) agglomerates. The tests also permitted identification and correction of operating problems in areas of coal feed, product screen performance, waste treatment, etc.

\subsubsection{Equipment Studies and Modification}

Sections 4.2.2. in Volume 1 and Volume 3 discuss equipment modifications made to the IATF in the course of the program. Equipment modifications conducted specifically for the Aglofloat process (the design of the hydraulic separator) was described in Section 4 of this report.

\subsubsection{Pilot Plant Tests}

Following the incorporation of the hydraulic separator into the Integrated Agglomeration Test Facilities (Process Flowsheet \#ARC55), a series of continuous runs was pertormed with Illinois No. 6 ROM coal. The objective of these runs was to optimize the high shear step operation with respect to bridging oil concentration and the relative performance of the floatation cell and hydroseparator. Figures 5.1 to 5.6 depict the effect of bridging oil concentration on the pyritic sulphur and ash contents in the floatation and hydrocarbon classifier product for uns \#18, 19 and 20. A summary of the optimization runs is presented in Figures 5.7 and 5.9. More detailed process data for each run are presented in 


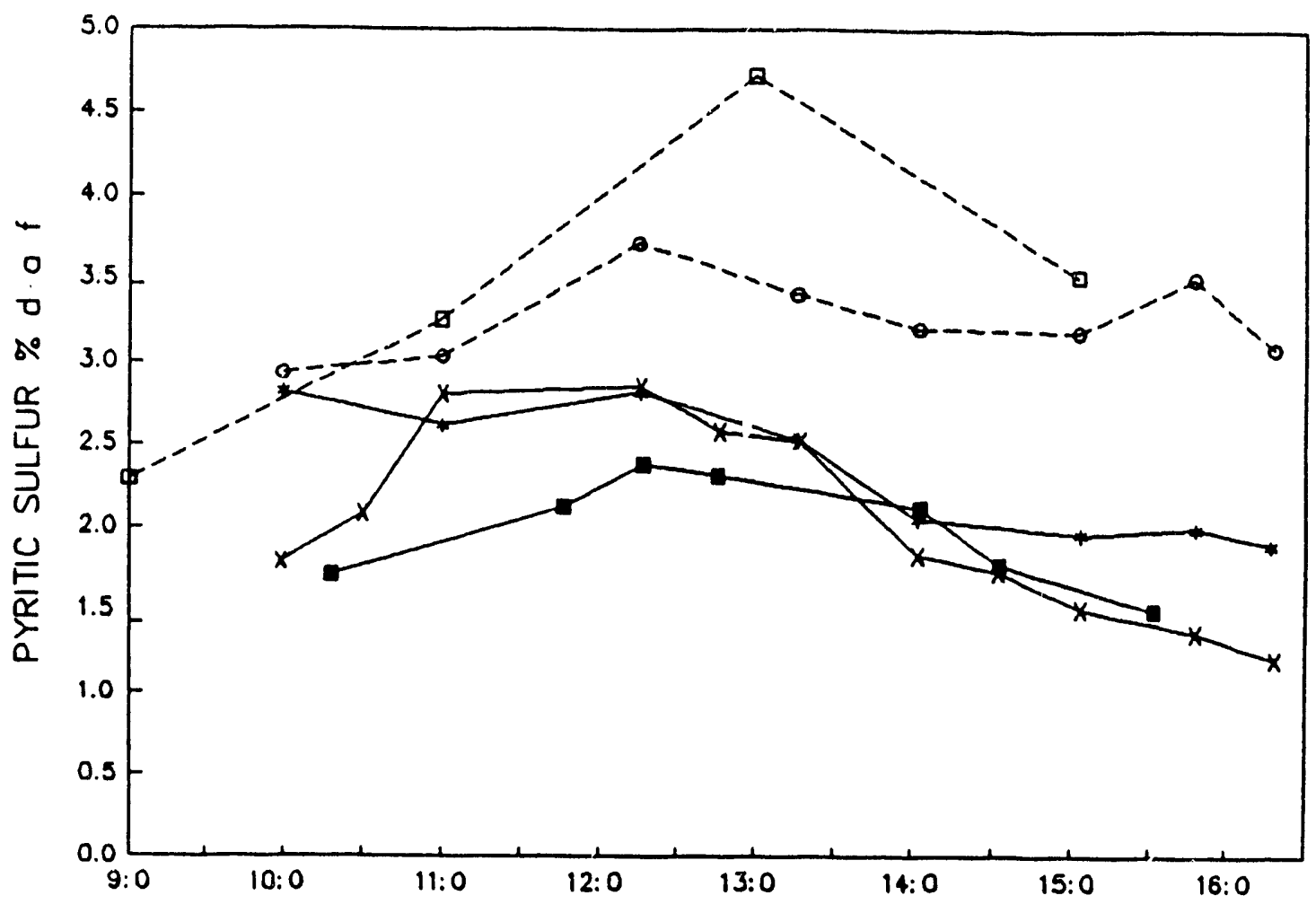

TIME

Figure 5.1. Pyritic suphur removal in IATF Run 18. leed; product; floatation feed; ' floatation product; $X$ hydroseparation product.

Appendix 4. The key process design and development conclusions were:

- Pyritic sulphur content after floatation ranged from 2.5 to 3.0 percent for oil concentration 1.0 to 3.0 percent. Al 0.5 percent of bridging oil concentration, the products pyrite content was less than 1.5 percent. This was because of poor coal recovery.

- For the same oil addition of 1.0 to 3.0 percent, the coal recovery after pyrite separation was about 90 percent. At bwer oil concentration, coal recovery ranged from 60 to 86 percent.

- The plots of coal recovery versus pyrite content in the clean coal products generated curves similar to washability curves. The results suggest that product with about 2 percent of pyrite may be obtained for coal recovery of 90 percent in the IATF.

\subsection{Conclusions}

The Integrated Agglomeration Test Facilities were modified by incorporating a hydraulic classifier in order to obtain process and engineering information on the Aglofloat process. Specitically, the plant was to provide information on scale-up of the Aglofloat process, on technical feasibility of the Aglofloat process and on the process control required. The plant included all Aglofloat unit operations except for equipment required for primary crushing of ROM coal.

The major process areas and unit operation of the pilot plant included coal grinding and slurry preparation, oil preparation, microagglomeration, floatation, pyrite separation, macroagglomeration.

macroagglomerates' separation, and waste treatment. The IATF instrumentation included process control and data acquisition hardware and sottware. 


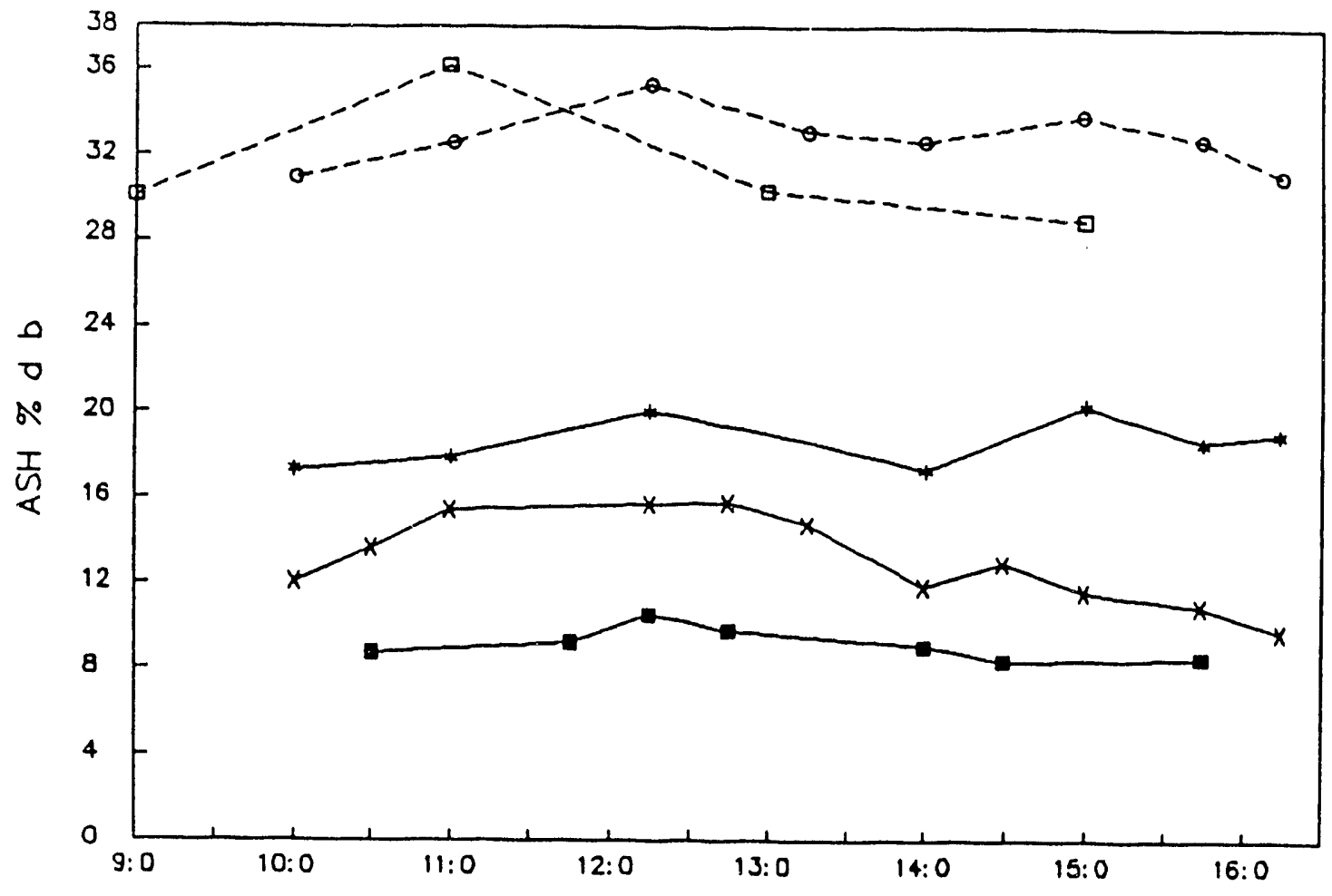

TIME

Figure 5.2.Ash removal in IATF Run 18. $\square$ feed; $\square$ product; O floatation feed; $\bullet$ floatation product;

$X$ hydroseparation product.

The IATF test runs confirmed that well-formed agglomerates with reduced sulphur and ash can be obtained from bituminous coals. The agglomerate product properties were similar to those obtained in the batch and continuous bench-scale experiments, with agglomerates heating value above 13,000 Btu/lb, ash less than 10 percent, and sulphur significantly reduced below that of raw coal.

Design specifications selected for the conceplual Aglofloat process, based on IATF tools performed with Illinois No. 6 ROM coal are as follows:

- oll addition - high shear: 0.8 percent, d.b. feed coal.

- oil addition: 12 percent, d.a.f. coal feed basis.
- residence time: $4 \mathrm{~min}$. high shear mixer (HSM). $25 \mathrm{~min}$. low shear mixer (LSM).

- slurry concentration: 30 percent in HSM. 18 percent in floatation cells and hydraulic separator. 30 percent in LSM.

- product agglomerate size: 0.8 to $3.0 \mathrm{~mm}$.

- molsture in agglomerate: 40 percent in froth. 20 percent in agglomerate product.

- combustibles recovery: 95 percent, w/w coal Btu basis.

- ash rejection: 69 percent, w/w coal ash basis.

- pyritic sulphur rejection: 59 percent, w/w coal sulphur basis. 


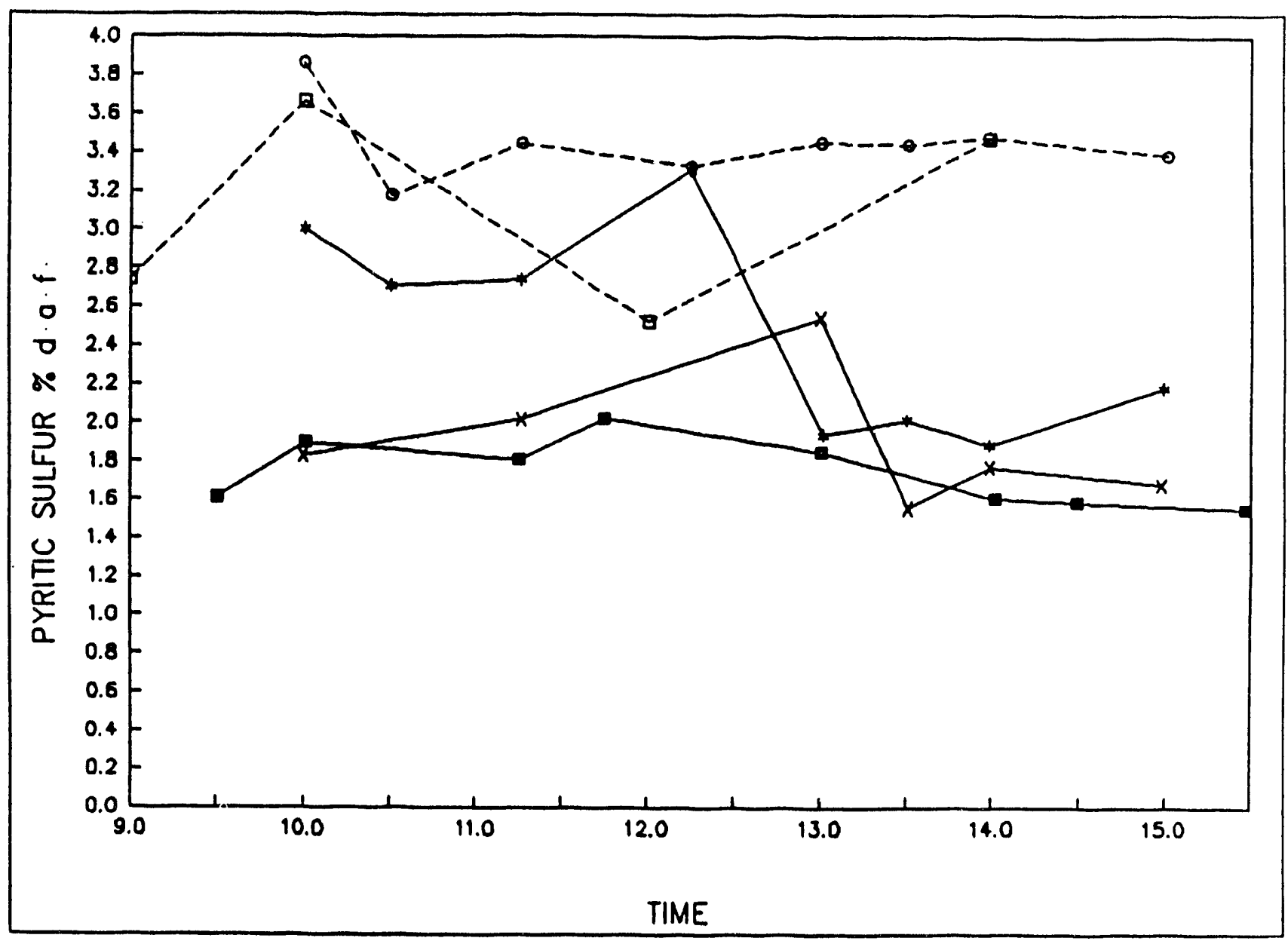

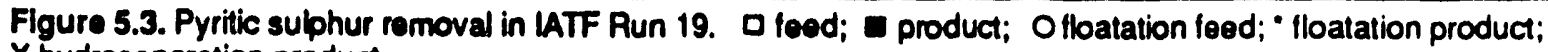
$X$ hydroseparation product. 


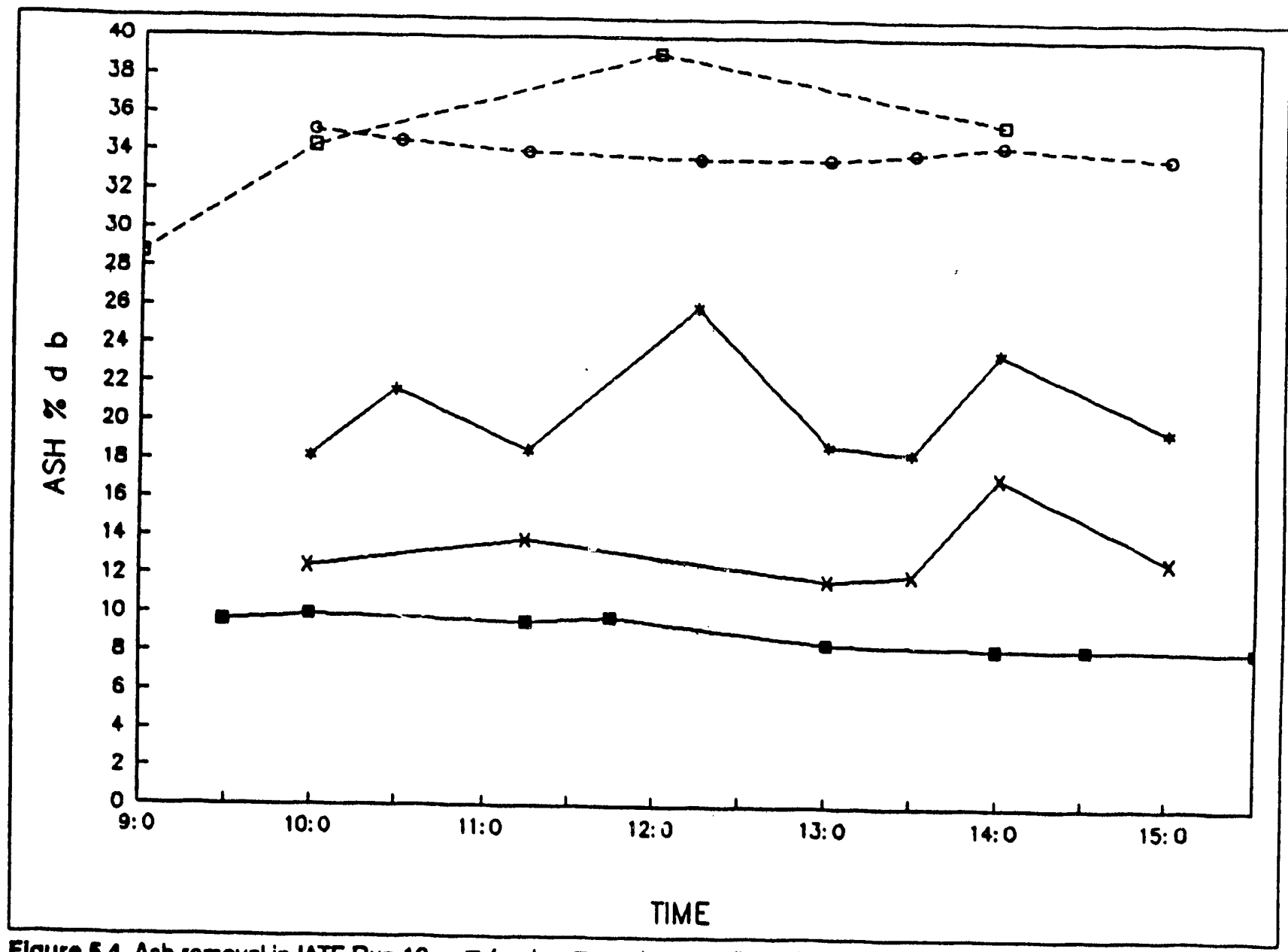

Figure 5.4. Ash removal in LTF Run 19. D lead; a product; O floatation feed; • floatation produc.,
$X$ hydroseparation product. 


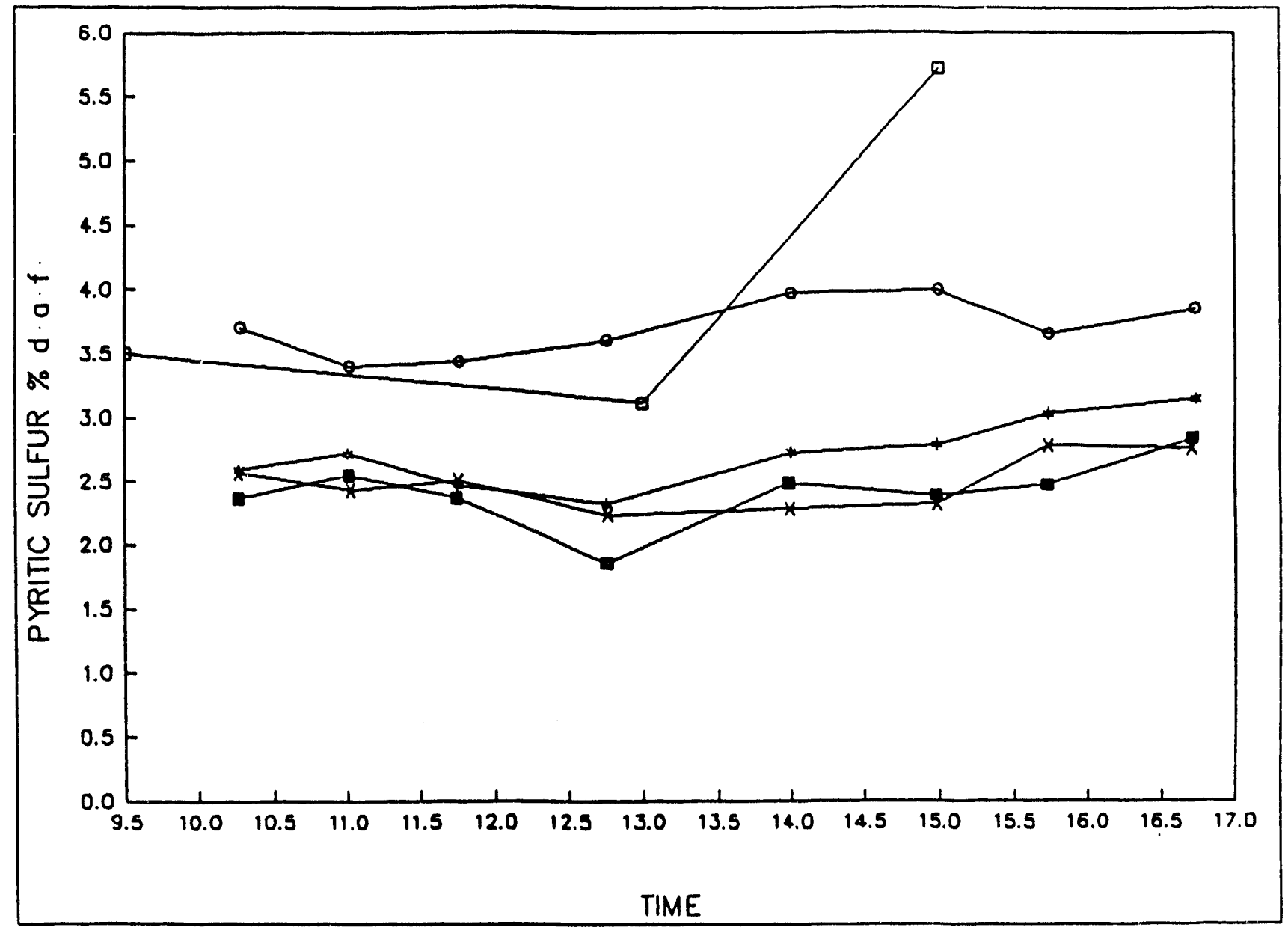

Figure 5.5. Pyritic sulphur removal in IATF Run 20. $\quad$ foed; $\square$ product; $O$ floatation feed; " floatation product; $X$ hydroseparation product. 


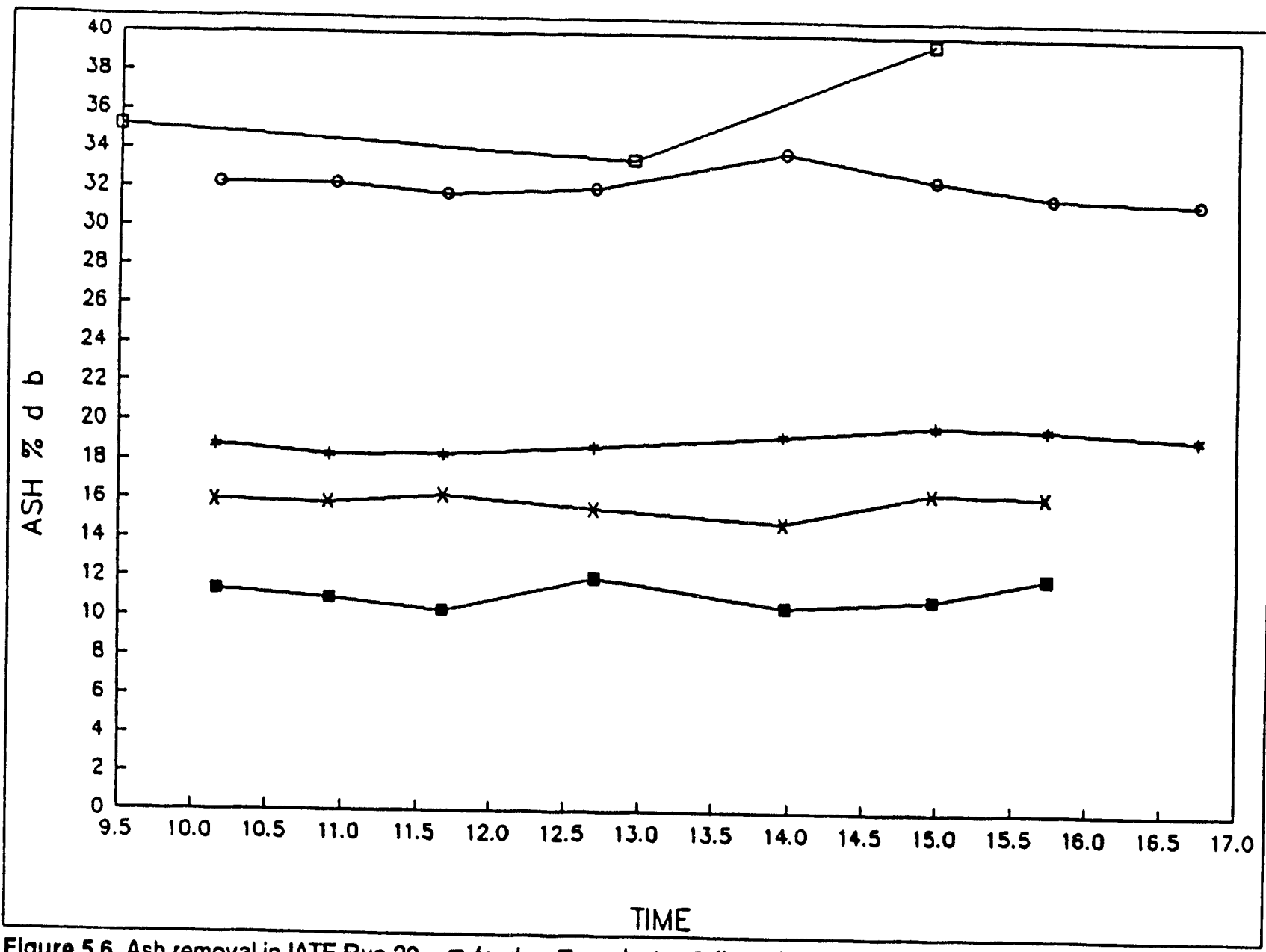
Figure 5.6. Ash removal in LTF Run 20. 0 loed; a product; O floatation feed; ‘ floatation product;
$\mathrm{X}$ hydroseparation product. 


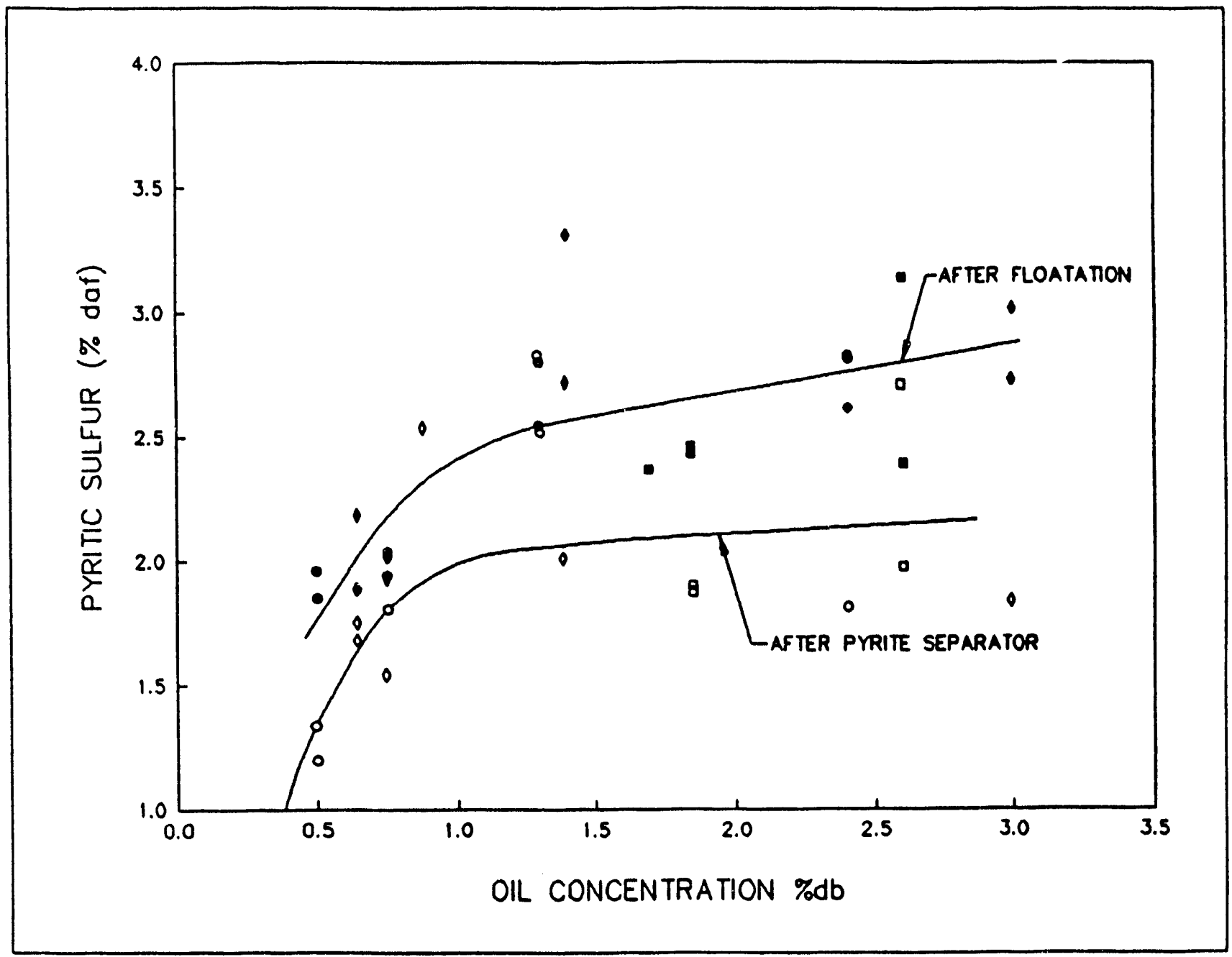

Figure 5.7. IATF Runs: Elfect of oil concentration on pyritic sulphur removal. $\square$, Run 17; 0 . Run 18;

$\diamond$. Run 19; open symbols = product after hydraulic separation, solid symbols = product after floatation colls. 


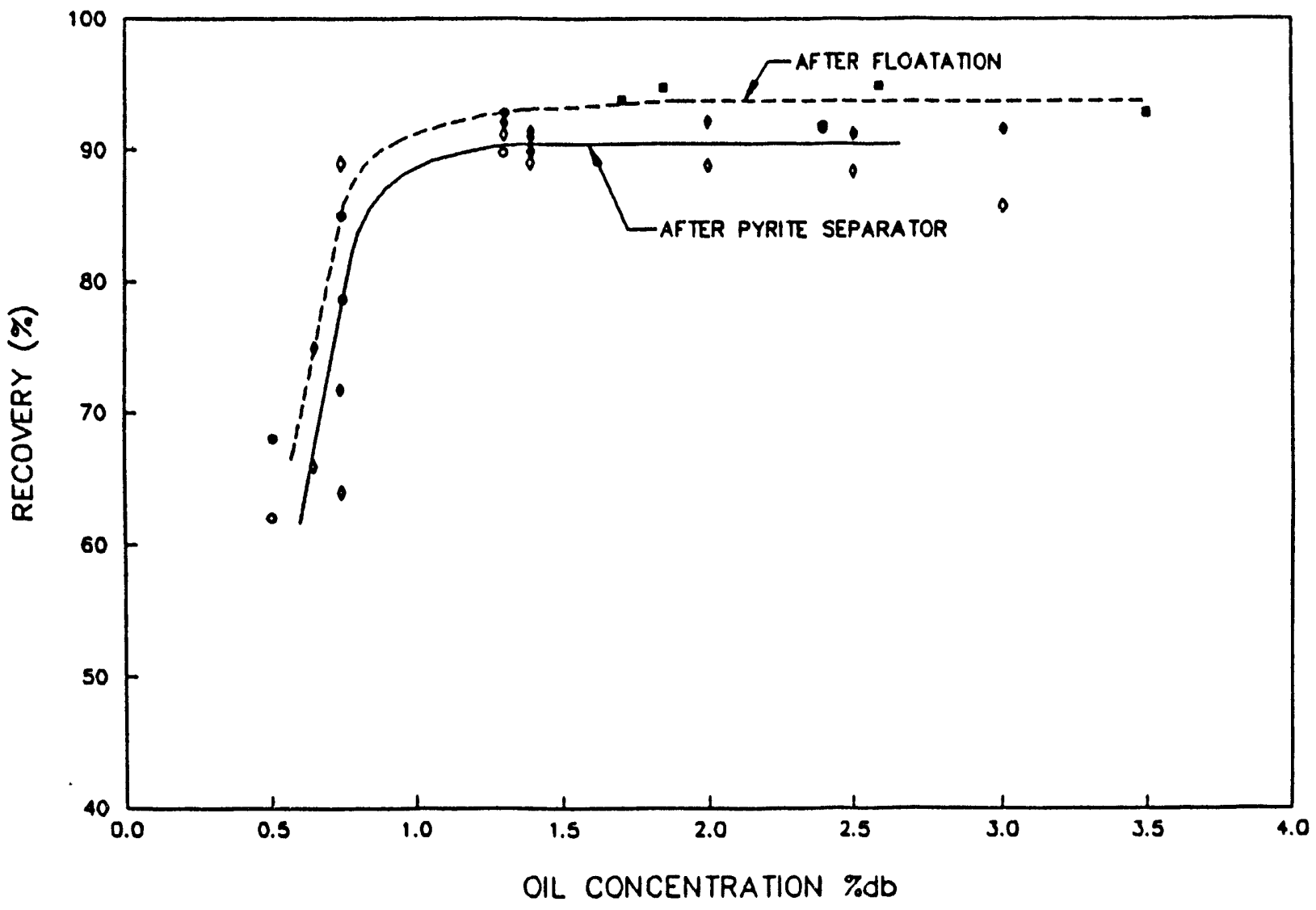

Figure 5.8. IATF Runs: Effect of oil concentration on coal recovery. $\square, \square$ Run 17; $0, \bullet$ Run 18; $\diamond, \diamond$ Run 19; open symbols = product after hydraulic separation, solid symbols = product after floatation cells. 


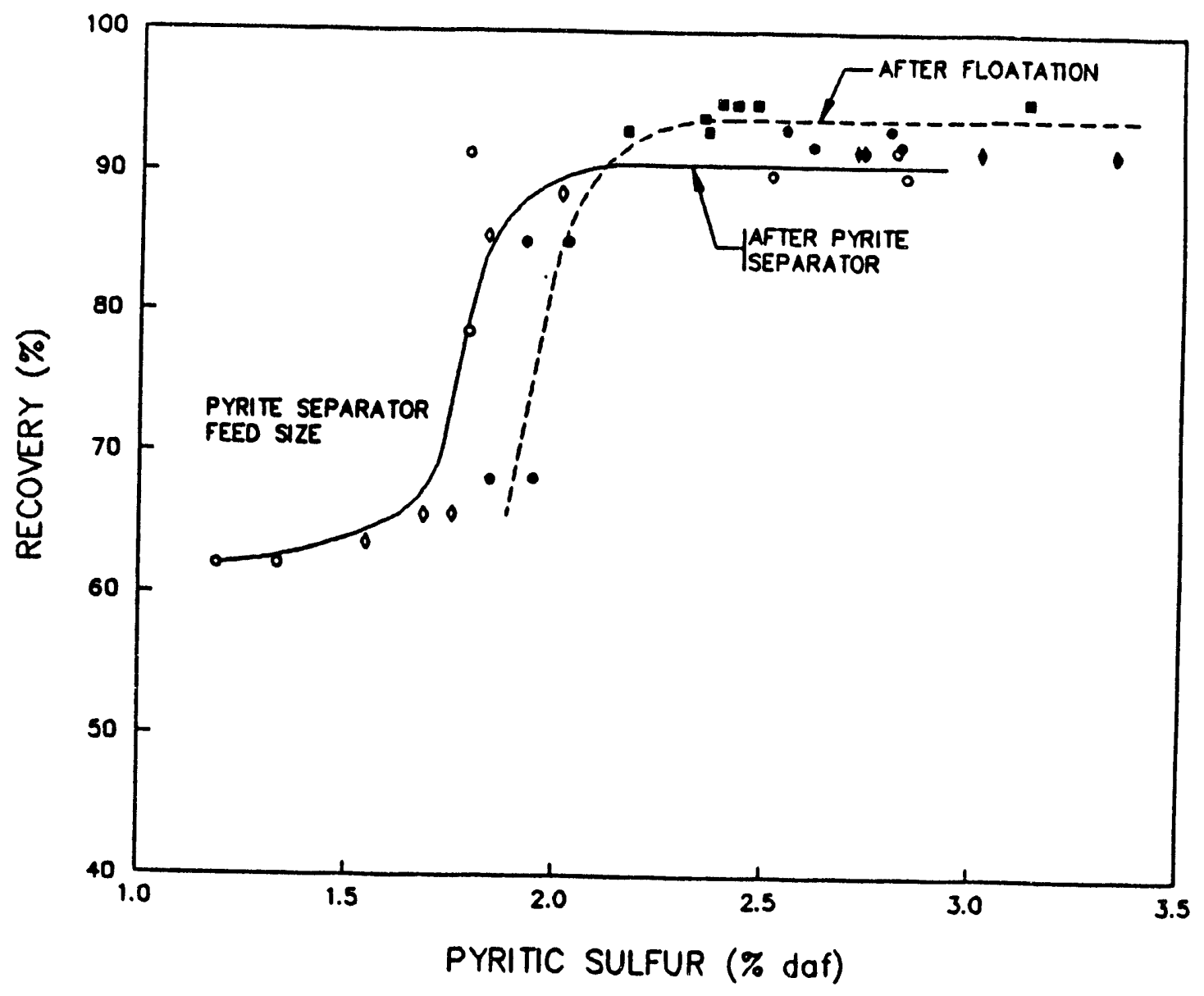

Flgure 5.9. IATF Runs: Recovery curves for floatation and pyrite separation units. $\square$, Run 17; 0,0 Run 18; $\checkmark$. Run 19; open symbols - product atter hydraulic separation, solid symbols a product after fbatation colls. 
The design assumptions for the Aglofloat process in Section 7 require that the plant meets EPA 1989 standards for air, water and refuse discharge from the plant. The key control requirements with respect to plant emissions are:

- air contaminants such as coal and mineral matter dust, hydrocarbon vapors, etc.;

- water contaminants including nunoff water from coal stockpiles, recycle water ponds, etc.; and

- refuse contaminants in the refuse coal.

The following section briefly describes the design approach proposed for the major effluent streams.

\section{Ar Emissions}

The major sources of air emissions are the coal and oil handling areas. Potential dust and hydrocarbon emissions in those areas were eliminated by the incorporation of dust and hydrocarbon collection systems in the plant design. The performance required for dust and hydrocarbon collection systems will be determined by the National Ambient Quality Standards.

\section{Water Contaminants}

The Aglofbat plant requires a net makeup of process water from wells or surface water sources. The majority of plant water contaminants will come from nunoff waters from coal and agglomerates storage and emergency refuse stockpiles. The plant design calls for collection of nunoff water and use of this water as a makeup water.

The recycle water streams are clarified in two static thickeners in the Agglomeration and Floatation Area

\section{Refuse Dlsposal}

It is expected that the refuse will be disposed of either in the mined pits (in case of the strip mines) or at a disposal site near the coal upgrading plant. The construction and operation of the disposal site will be governed by the Mine Safety and Health Administration (MSHA) regulations. Key considerations in selection, preparation and maintenance of a refuse site are:

1. Base (foundation) at the site should be stable and have low permeability.

2. Erosion due to surface water drainage should be prevented.

3. Refuse should be weathered before it is placed in the refuse site.

4. Refuse should be spread in layers and compacted. Fresh and older refuse should not be mixed.

5. Regular inspection and maintenance should be conducted at the site.

A disposal cost of $\$ 7$ Mon of coal refuse is assigned to the plant operating cost. 


\section{Conceptual Design and Cost Analysis of an Integrated Commercial Plant for the Aglofioat Process}

\subsection{Process and Economic Data}

\subsubsection{Design Basis and Assumptions}

Plant Slzo

A conceptual plant size of 2.8 million tons nominal capacity of input ROM coal was used. This size of plant permits relative economies of scale in mining. in transportation and in the operation of the plant itself. As well, it is suitable for the initial target markets.

\section{Plant Load Factor}

It is assumed that the Aglofloat plant will be operating about 7000 hours per annum. It is recognized that this bad factor will determine the degree of redundancy of plant equipment, and will intuence other design comporents such as the storage of products, otc.

\section{Piant Location}

The conceptual design was not intended for a specific plant site. It is assumed that the plant will be a mine-mouth plant bocated in the Appalachia region of the U.S. and that it will not have any unusual topographical problems.

\section{Plant Equlpment}

The plant equipment selected is commercially avait able. Also, where possible, support areas such as water treatment have been costed as tum-key, package plants.

\section{Plant Boundary}

The plant boundary, for costing purposes, incudes all facilities required to operate the plant, to unload fuel, to bad the upgraded procucts and to treat waste streams.

\section{Emironment Gudy}

Al plar?. process units are designed to meet 1989 emission standards in the U.S.

\section{Feodstock and Procuct Varlabllity}

All calculations of material and heat balances and sizing of equipment were performod using the ROM coal in Table A5.9 in Appendix 5. Table A5.9 also depicts properties of the refuse coal.

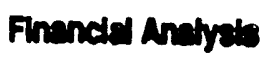

All she financial analyses were performed in constant 1989 U.S. dollars.

\subsubsection{Sources and Methods of Process Cost Estimates}

Tables A5.1 10 A5.3, Appendix 5 depict the cost fac. fors used for estimating caplial and ainual operating costs for the conceptual plant. Table A4.4 lists prices and rates for chemicals, fuels, utillies, otc. used in the Agblbat cost estimates. The major sources of cost estimetes wore:

- vendors' estimates for equipment, and

- in-house data for equipmert and support areas.

All equipment costs weri updated to 1989 dollars using the Chemical Plant Cost Index or the MAS Equipment index.

\subsection{Process Description}

\section{Plant Descripition}

The beneficietion facility will upgrade 2.8 million tonnes of ROM coal per year based on 7000 hours per year. The production of saleable proctucts on an annual basis from the facilty will be 2.74 million tonnes of agolomerates with a heating value of 13,300 Burb.

The plant facilly has six operating areas as outlined below. The basic plant concept is shown in Fig ure 7.1. A more detalled description and a flowsheot for each area can be found in Appendix 5 of this study.

\subsection{Major Process Areas}

\section{Cod coliness Siorege and Crushing}

Coal is delivered io the plant in trucks owned by the coal company on a 12 hday $x 5$ dayshwoek basis. The ROM coel is fed from a dump hopper via an apron feeder to a coal breaker where il is recuced to $-150 \mathrm{~mm} \times 0$. Bell corveyors transfer the cushed coal either fonwand to the Aglofibat plant for uporading or to the outside storage area where 3-day live storage and 10-day compacted storage piles are bcated. Rocks are removed from the coal breaker and stockpiled at the rate of $10 \mathrm{tph}$. Bell scales have 


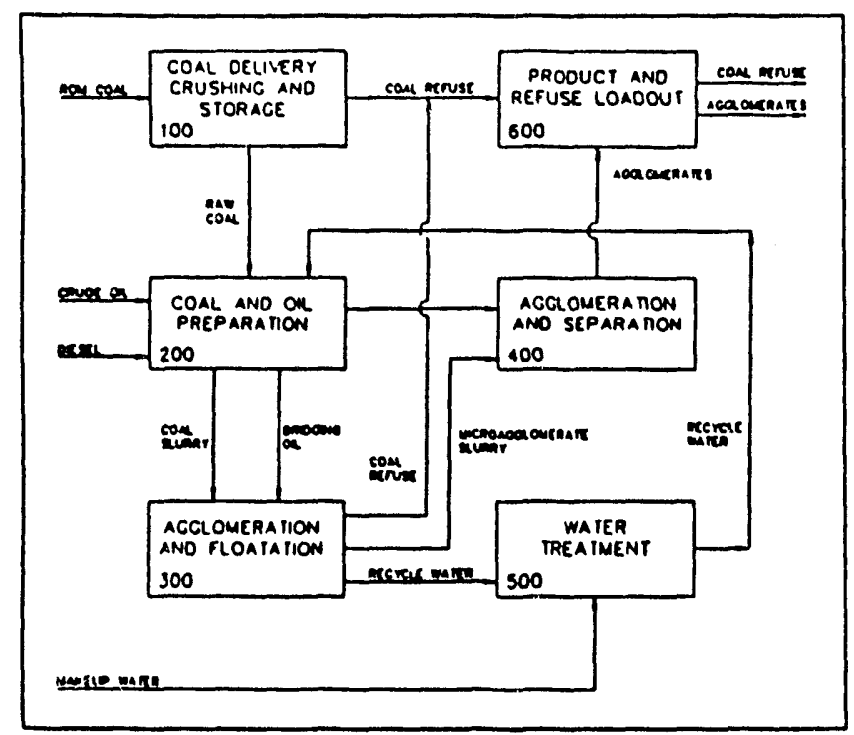

Figure 7.1. The Agbltoat Process.

been included to monitor the quantity of the coal deliveries.

The $-150 \mathrm{~mm} \times 0$ material that is directed to the plant is screened and crushed at the rate of $390 \mathrm{tph}$ to $-50 \mathrm{~mm} \times 0$ on a 24 hday $\times 7$ days/week basis.

\section{Coal and Heavy Oll Preparation}

Sized $-50 \mathrm{~mm} \times 0 \mathrm{~mm}$ coal is transferred by belt conveyor to four primary grind circuit mills operating in parallel. The inills pulverize the coal to 45 percent minus 100 mesh at the rate of $390 \mathrm{tph}$. The pulverized coal is slumied with 910 tph of water, and pumped to the Agglomeration and Floatation Area. The concentration of the coal slurried is about 29.4 percent dry coal, w/w basis.

Crude oil and diesel are delivered to the preparation area by a pipeline. The heavy oil is stored in a 50,000 bbl crude oil tank, ensuring a 5-day supply. The tank is insulated and a steam system is used to preheat the oil in water belore it is pumped to the bridging oil tank.

Diesel is stored in a 300 ton capacity tank. $0.4 \mathrm{tph}$ of diesel is mixed in a bridging oil tank with preheated crude oil at the ratio of $1104(w / w)$. The purpose of the bridging oil tank is to prepare an oil mix with optimal physical and chemical properties for agglomeration of coal.

\section{Agglomeration and Floatation}

The Agglomeration and Floatation area processes pulverized coal slurry at the rate of $1300 \mathrm{tph}$. The slurry is mixed with $2.0 \mathrm{tph}$ bridging oil in eight high shear mixers operating in parallel. The coal is wetted by oil and forms microagglomerates $\sim 0.2 \mathrm{~mm}$ in size, while coal mineral matter is deslimed in water. The output of high shear vessels is mixed with 823 tph recycle water to a slurry, dry coal concentration of 18 percent, and transferred to four floatation cells to separate coal from mineral matter. Each cell processes about $150 \mathrm{tph}$ of clean coal froth. The microagglomerates are transferred to four hydroseparators where they are diluted with 1291.7 iph recycle water, washed, separated from pyrite particles and transferred to a sump. The clean coal froth $(533.2 \mathrm{lph})$ is then again diluted with recycle water and pumped to the Agglomeration and Separation Area.

The floatation cell underllow is transferred to a static clarifier where refuse coal and mineral matter are separated from the recycle water, fittered in a vacuum filter, and after being combined with hydroseparator refuse, transferred to the reluse loading bin in the Product Loadout Area. The hydroseparator underflow is discharged into the second static thickener where refuse pyrite and coal are removed and filtered and water is recycled to the hydroseparator.

Approximately $70.5 \mathrm{tph}$ of refuse coal will be removed from the undertlow circuits of the floatation and hydroseparation units.

\section{Agglomeration and Separation}

The Agglomeration and Separation Area processes 1062 tph of microagglomerates slurry. The microagglomerates slurry is mixed with $38 \mathrm{tph}$ of crude oil in eight low shear mixers operating in parallel. The microagglomerates are enlarged to $0.8 \mathrm{~mm}$ to 3.0 $\mathrm{mm}$ macroagglomerates. The green macroagglomerates are discharged on four drain and rinse vibrating screens where they are dewatered 1025 percent moisture. The agglomerates are then transterred to eight centrifugal extractors operated in parallel, where they are further dewatered to 10 percent moisture. The final any agglomerate product is transferred to the Product Loadout Area at the rate of $392 \mathrm{tph}$.

All process water from the D\&R screens and the centrifugal extractor is recycled to the Coal and Oil Preparation Area. 
Water Treatment

Most of the process water from the plant is recycled back to the process areas. Each process area main tains its water chemistry by reusing the same water in each major process step. The process make-up water is well or surface water which is treated and stored in the water pond along with the treated recycle water.

\section{Product Loadout}

The agglomerates are transferred from the Agglomeration and Separation Area at the rate of 392 th into a 10,000 tonne live capacity stockpile. The agglomerates are withdrawn from the pile with vibrating feeders and transferred to a loadout bin for bading into conveyors via shuttle conveyor. The cars are weighed and the surface of the product is sprayed with a latex solution prior to shipment.

The coal refuse is loaded at the rate of 70.5 tph from a $500 \mathrm{t}$ capacity refuse bin. The refuse is loaded on trucks and hauled to the refuse disposal area. An allowance is made for an emergency 10. day refuse storage pile at the plant site.

Offiltes and Bulldings

The costs of offistes and buildings in this study have been factored from the total direct costs for each plant area.

\subsection{Cost Estimates and Financial Analysis}

\subsubsection{Capital and Operating Cost Estimates}

The evaluation of the direct plant cost for the Aglofloat process was based on individual costing of the six major process areas, using one of the following methods:

- Factored cost estimate based on vendor or in-house data for major pieces of equipment.

- Factored cost estimates based on equipment capacity and published cost estimates for the process area.

The accuracy of the individual process area cost estimates is expected to be $\% 30$ percent.

A summary of Total Capital Cost for the Agflotherm process is presented in Table 7.1. The table also depicts Working Capital and Total Plant
Cost. Total Plant Cost consists of the Total Direct Cost, EPCM, and contingency for each plant area.

The EPCM costs were estimated at 20 percent of the total direct cost for each plant area. This cost covers the cost of process and project engineering. design drafting, engineering procurement and construction management.

The Contingency Cost estimates were based on the direct cost and the uncertainty associated with each plant area. Forexample, the contingency is 35 percent for the Agglomeration and Separation Area, 20 percent for Water Treatment, and 10 percent for the Coal Delivery, Storage and Crushing Area. This cost covers possible additional costs that would resull trom a more detailed design of the plant at an actual site. A description of the contingency factors is given in Table A5.5, Appendix 5 .

A summary of working capital is provided in Table 7.2. The cost data and assumptions used for calculation of the working capital cost elements are presented in Appendix 4. A summary of the annual operating costs is presented in Table 7.3. The cirect operating costs were estimated as follows:

- ROM coal was assumed at $\$ 27 n$ (f.o.b. plant),

- fuel cost (natural gas) at $\$ 2.90 / M M B t u$,

- raw water cost at $\$ 0.60 / 1000$ gallons,

- electricity at $\$ 0.0 .65 / \mathrm{kWh}$,

Table 7.1. Total capital cost: Aglofbat.

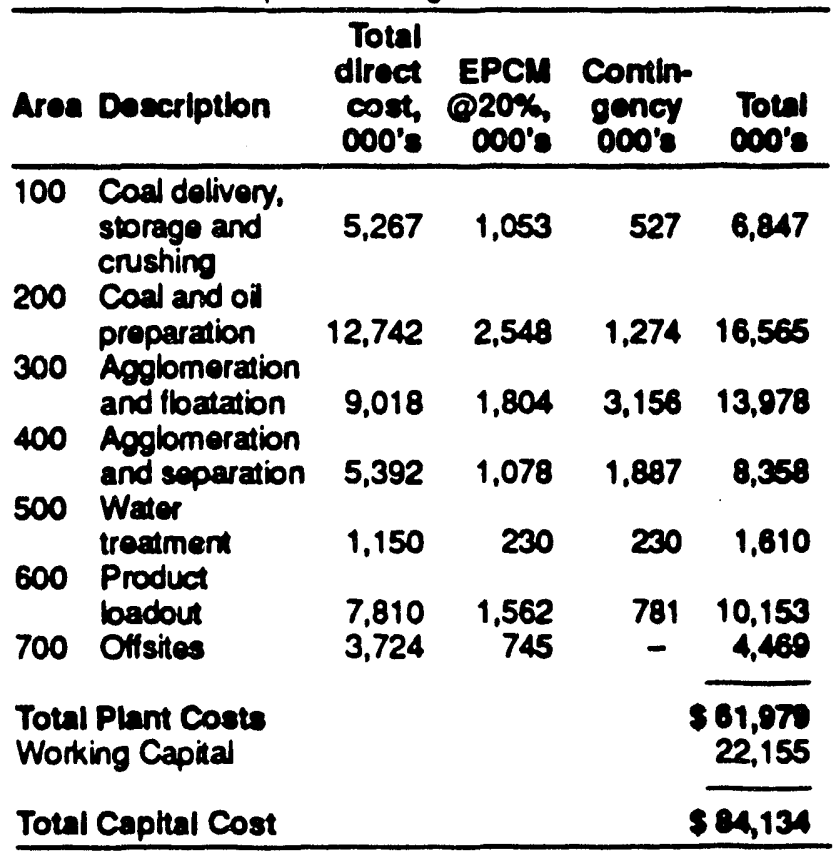


Table 7.2. Working capital summary: Aglofloat.

\begin{tabular}{lc}
\hline Description & C00'S \\
\hline One Month of Operating Cost & 10,088 \\
One Month of Accounts Receivable & 12,067 \\
& $\frac{22,155}{\text { Total Working Capltal }}$
\end{tabular}

- chemicals and operating labour as summarized in Table A5.7, Appendix 5; and

- inaintenance labour and materials as summarized in Table A5.8, Appendix 5.

The indirect operating costs were estimated as follows:

- the administrative and support labour at $15 \%$ of direct operating and maintenance labour,

- the general administrative expense at $60 \%$ of direct operating and maintenance labour, and

- property taxes and insurance at $1.5 \%$ per year of Total Plant Cost.

\subsubsection{Financial Analysis}

The criteria for the financial analysis of the Agthotherm process and costing of the product (f.o.b. plant) included:

- equity financing:

100 percent

- taxable rate: $38 \%$ annually

- construction allocation:

- plant life:

- depreciation:

- plant load:

over 3 years

25 years straight line over $10 \mathrm{yrs}$ $80 \%$

It is assumed that the plant will be in full production in the fourth year after the start of construction. It is also assumed that an inventory consisting of a ROM coal stockpile of 100,000 tons, 10,000 tons of agglomerates and 10,000 tons of crude oil inventory is established in the first-year. These inventory costs are included in the first year's operating cost but not in the revenue calculation.

\section{Base Case}

A summary of the Base Case financial analysis is presented in Table 7.4. The analysis is based on the following financial assumptions:

- Total Plant Production: $2.74 \times 10^{6}$ yy agglomerates

- Total Plant Cost: $\$ 61,979,000$

- Total Operating Cost: $\$ 121,100,000$

- Coal Price: $\$ 27 n$
Table 7.3. Operatina cost summary: Aglofloat.

\begin{tabular}{lr}
\hline Direct Cost & 000 'S \\
\hline ROM Coal & 75,600 \\
Crude Oil and Diesel & 28,441 \\
Diesel & 500 \\
Fuel & 131 \\
Electricity & 6,132 \\
Chemicals & 765 \\
Operating Labour & 1,578 \\
Maintenance Labour & 720 \\
Maintenance Materials & 1,081 \\
Refuse Disposal & $\mathbf{3 , 4 5 5}$ \\
Total Direct Cost & $\mathbf{1 1 8 , 4 0 2}$
\end{tabular}

\section{Indirect Cost}

Administrative and Support Labour $\quad 345$

General and Administrative Expense $\quad 1,379$

Property Taxes and Insurance

Total indrect Cost

2,654

Total Operating Cost

Table 7.4. Summary of plant revenue and costs over the plant life: Aglofloat.

\begin{tabular}{lr}
\hline Total Cash Flow & \\
\hline + Rovenue & $3,620,000,000$ \\
- Total Oporating Cost & $3,027,500,000$ \\
- Working Capital & $22,155,000$ \\
- Income Tax & $202,000,000$ \\
- Equity Capital Cost & $61,979,000$ \\
\hline - Net Cash Flow & $306,366,000$ \\
DCF Rate of Return, \% & 15 \\
\hline
\end{tabular}

- Crude Oil Price: $\$ 102.60$ r

- Diesel Price: $\$ 178.401$

- DCF ROR (after taxes): 15\%

\section{Varlance Analysls}

The impact of major economic and process assumptions was studied by performing sensitivity analyses with respect to those assumptions. All variance cases are presented in relation to the Base Case analysis (Figures 7.2 to 7.5).

\section{Amount of Oll for Agglomeration}

The agglomerate prices were based on the addition of 12 percent of oil (coal basis) for size enlargement of the agglomerates. ARC's process development work is currently directed towards reduction of the 


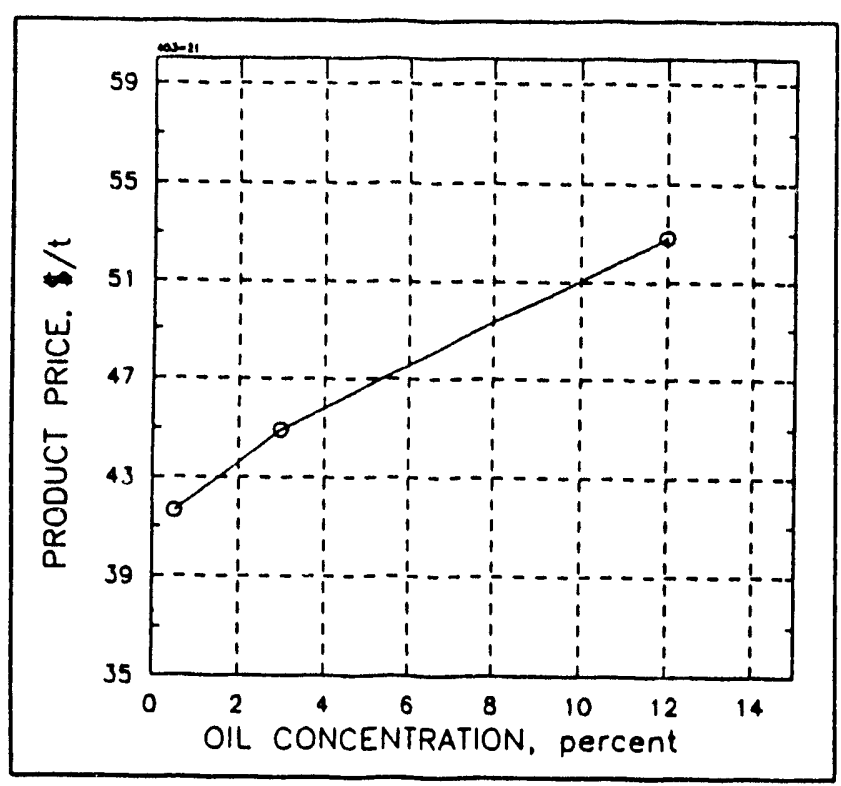

Figure 7.2. The effect of oil concentration on product price (Aglofloat).

amount of oil, and, hence, reduction of agglomerate price. Two more cases were, therefore, evaluated in the variance analysis. These cases were a 3 percent oil addition for agglomerates size enlargement based on the anticipated process improvements and a 0.5 percent oil additior, in agglomeration based on elimination of the size enlargement step.

Base Case: 12 percent (dry, ash coal feed basis).

Decrease I: $\quad 3$ percent ( $d r y$, ash coal

feed basis).

Decrease II: $\quad 0.5$ percent (dry, ash coal feed basis) less capital and O\&M for Area 400.

Total Plant Cost

The plant Total Capital Cost is based on the expected cost, estimating aosuracy of $\% 30$ percent. The performed variance analysis included:
Base Case:
$\$ 61,979,000$.
Decrease:
$\$ 43,385,000$

Increase:

(Base Case - 30 percent).

$$
\$ 80,573,000
$$

(Base Case + 30 percent).

\section{Operating Cost}

Allowances for the variance in Total Operating Cost included the following factors:

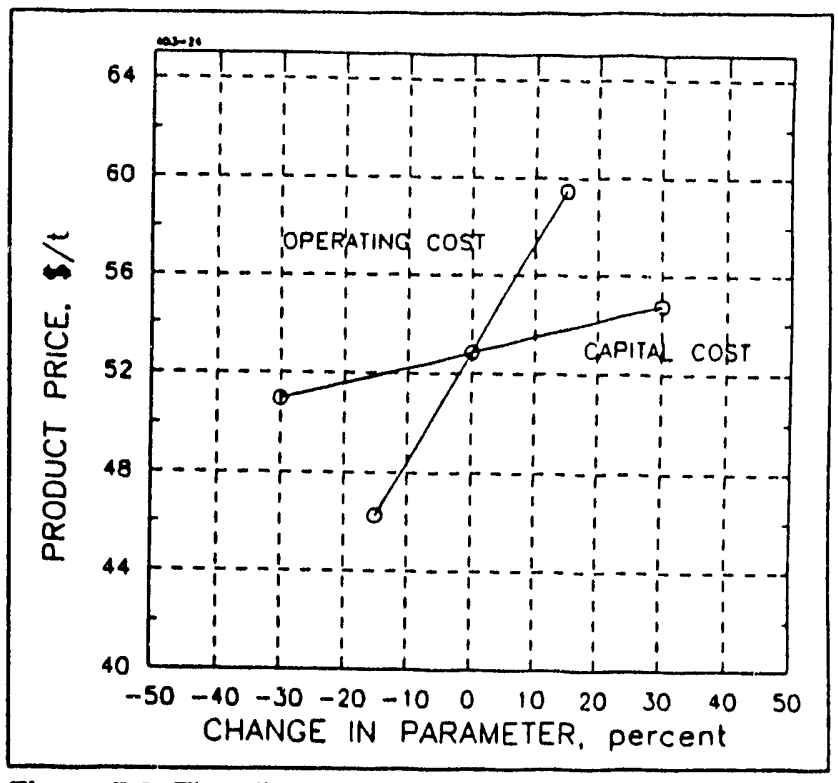

Flgure 7.3. The effect of capital and operating cost on product price (Aglofloat).

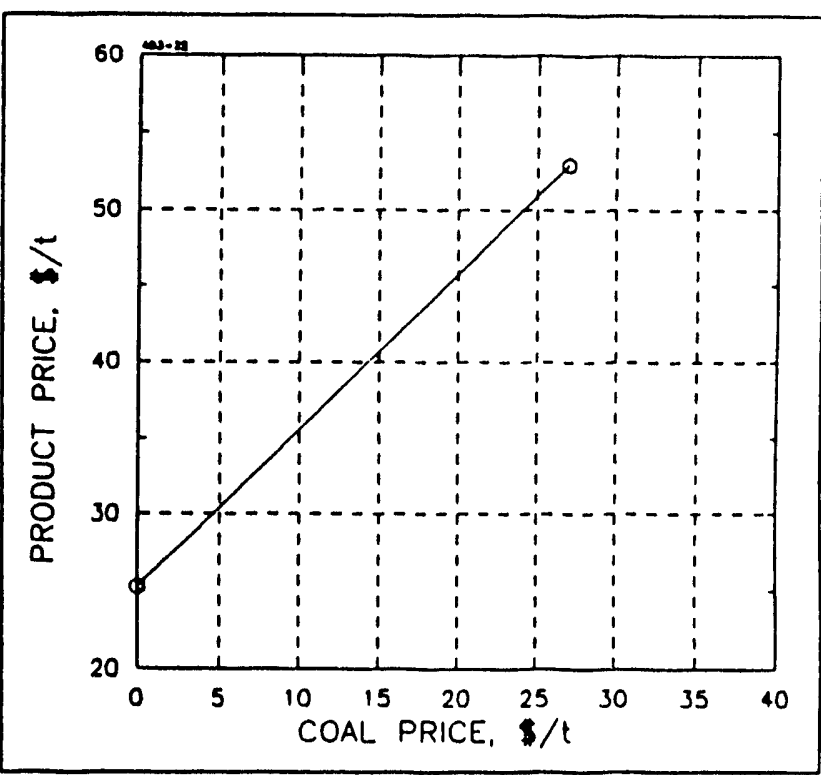

Figure 7.4. The effect of coal price on product price (Aglofloat).

Base Case:

$\$ 121,100,000$.

Decrease:

$\$ 102,935,000$

(Base Case - 15 percent).

Increase:

(Base case + 15 percent). 


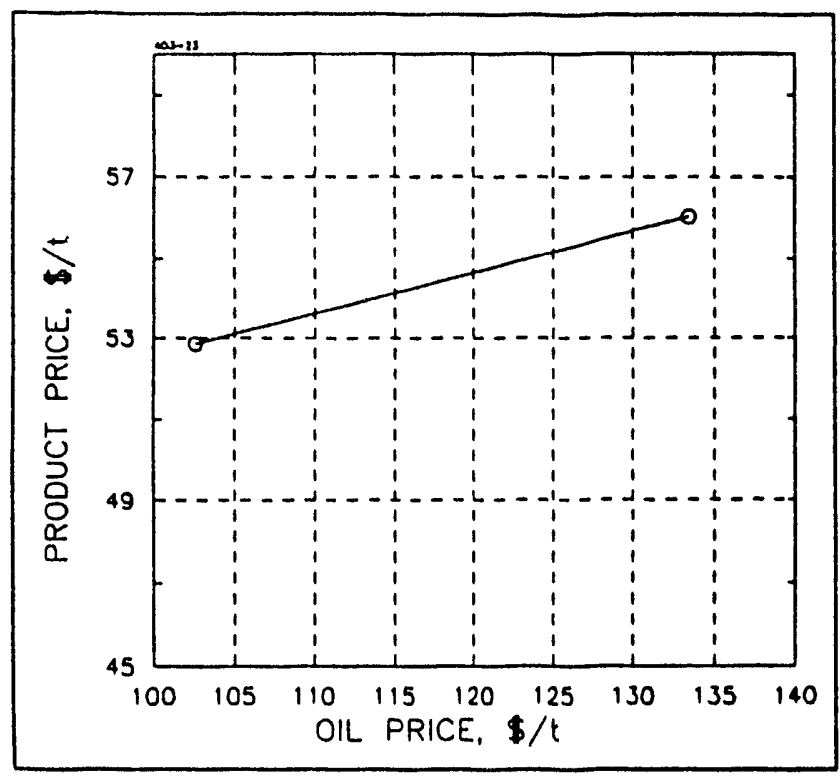

Figure 7.5. The effect of oil price on product price (Aglofloat).

\section{Coal Cost}

The price of $\$ 27 / 4$ was recommended for 2 to 3 million tonnes of ROM coal. The sensitivity analysis included the following ROM coal prices:
Base Case:
$\$ 27 /$.
Decrease:
$\$ 0 / t$ (coal refuse from a coal preparation plant).

\section{Oil Cost}

The Mexican Maya crude (22\# API) was priced out of U.S. Gulf Coast less the WTVMaya crude differential of $-\$ 4.00 / \mathrm{bbl}$, plus a transportation tariff of $\$ 1.00 / \mathrm{bb}$ to Northern Appalachia.
Base Case: Increase:
$\$ 102.60$ tion.

$\$ 133.40$ ton

(Base Case +30 percent).

\subsection{Process and Market Economic Implications}

\subsubsection{Breakdown of Product Cost}

Table 7.5 presents a breakdown of the prices of agglomerates according to various process cost factors. The key cost factors are discussed below.

The cost of coal and oil are the largest cost factors involved. They are, respectively, $\$ 27.59$ and
Table 7.5. Breakdown of the estimated cost for agglomerates'.

\begin{tabular}{|c|c|c|c|}
\hline Cost Factors & 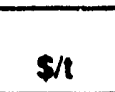 & $\begin{array}{l}\text { Product Cost' } \\
\text { S/MMBtu }\end{array}$ & $\%$ \\
\hline \multirow[t]{2}{*}{$\begin{array}{l}\text { ROM Coal } \\
\text { Bitumen and Light Oil } \\
\text { Operating Cost } \\
\text { Capital Charge }\end{array}$} & $\begin{array}{r}27.59 \\
10.56 \\
6.03 \\
8.67\end{array}$ & $\begin{array}{l}1.04 \\
0.40 \\
0.23 \\
0.33\end{array}$ & $\begin{array}{l}52.2 \\
20.0 \\
11.4 \\
16.4\end{array}$ \\
\hline & 52.85 & 1.99 & 100.0 \\
\hline
\end{tabular}

1: DCF ROA equals 15 percent, 13,300 Btulb product.

$\$ 10.56$ per ton of agglomerates, or 52.2 and 20.0 percent of the product price.

The charge is $\$ 8.67$ per ton or 16.4 percent of the product price. The operating component of the product price is $\$ 6.03$ per ton or 11.4 percent.

\subsection{Conclusions}

A conceptual design and a cost analysis were developed for the Aglofloat process. The process description, process data and design were based on tests performed in batch laboratory experiments, the CPRU and the IATF. The plant was to upgrade 2.8 million short tons of ROM coal per year to 2.74 million tons of agglomerates with 13,300 Btu/b heating value, 6.2 percent of ash, and 2.5 percent of total sulphur. The plant was assumed to be a mine-mouth plant located in the Appalachia region of the U.S.

The majority of the plamt areas and equipment selected were commercially proven and available. the exception was the Agglomeration and Floatation Area where a new design was proposed for the hydraulic separator. Because of the similarity of the hydraulic separator to the floatation cell, the cost of the hydroseparator was factored from the floatation cells' cost estimates.

The financial and variance analyses performed indicated the Base Case product cost, at 15 percent DCF ROR, equaled \$52.85/t. The Base Case Total Plant Cost was $\$ 61,979,000$, Operation Cost was $\$ 121,056,000$ and Working Capital was $\$ 22,155,000$. The costs of coal and bridging oil were the largest cost factors involved (52.2 and 20.0 percent, respectively) while the capital charges and operating cost combined contributed the remaining 20 percent. 


\section{Summary and Recommendations}

The study's objective was to apply advanced agglomeration technology for upgrading of high sulphur bituminous coals. The results achieved included development of the Aglofloat process for upgrading of bituminous coals to a solid fuel with a heating value of above 13,000 Btu/lb, ash content less than 10 percent, and reduced pyritic sulphur coritent (up to 95 percent). The work completed also suggested further process research and development needs which are summarized below.

\section{Batch-Test Studies}

Two types of laboratory tests were developed for characterization of bituminous coal clean-up in the Aglofloat: single-stage and two-stage tests. The tests indicated that two-stage processing with interstage regrinding resulted in more ash and sulphur removal but also higher loss of combustible materials. The choice of the Aglofloat procedure would depend, therefore, on the amount of sulphur removal and coal recovery required for each specific coal.

The process variables studied (bridging oil concentration and preparation, coal concentration, addition of surfactants, etc.) provided information on the key factors influencing the Aglofloat performance with bituminous coals. It was found, for example, that for western Canadian bituminous coals, the Aglofloat procedure had to be modified in order to achieve high combustbles recovery ( 90 percent or higher). The modified procectures called for addition of surfactants and bridging oil at 3 percent concentration ( $w / w$ dry coal basis) versus 0.5 percent for the U.S. bituminous coals. It is recommended, therefore, that further detailed batch tests be conducted to study process issues such as:

- The effect of coal properties and preparation on agglomeration kinetics, and the required bridging oil addition.

- The use of surfactants änd other pretreatment methods for agglomeration of "difficult" coals.

- Development of predictive methods for characterization of the Aglofloat performance with different bituminous coals.

\section{Contmuous Pyrite Removal Unit}

The completed tests provided information on the feasibility of using hydraulic and flume separators for the removal of pyrite from bituminous coal flocs. Both unit processes showed reduction of pyrite in the coal product; however, a system including a floatation cell and hydraulic separator was chosen over a more operationally complex system which included a flume separator.

The experiments conducted with high sulphur IIlinois No. 6 coal indicated that at best conditions, the combustibles recovery ranged from 75 to 80 percent, the total sulphur reduction ranged from 50 to 55 percent, the pyritic sulphur reduction ranged from 72 to 77 percent, and the ash reduction ranged from 82 to 86 percent. The important operation parameters identified were oil, frother and coal concentration, size of coal, high shear mixer operating condition (speed and residence time).

The CPRU was successfully used for the scale-up of the hydraulic separator for the large pibt plant (IATF). The design procedures developed were also helpful for further optimization of the hydraulic separator in the IATF.

In general, the CPRU required more bridging oil than the IATF or batch tests. Further recommended studies and equipment modification for the CPRU included:

- Installation of a second high shear mixer to increase HSM mean residence time for slumies requiring higher inversion times.

- Installation of a second floatation cell in series with the floatation tailings to recover coal from the tailings.

- Installation of accumulation vessels for the floatation cell and hydraulic separator to facilitate periodic removal of the accumulated solids.

- Further studies of the main factors and interaction effects in agglomeration of different bituminous coals.

- Funther development of correlation and scale-up equations for the CPRU and IATF.

\section{Integrated Agglomeration Test Facilities}

A hydraulic separator was incorporated in the IATF to operate the pilot plant in the Aglofloat process configuration. The IATF nus confirmed that well-formed, reduced in sulphur and ash agglomerates can be obtained in the Aglofbat process. The agglomerates had a heating value above $13,000 \mathrm{Btu} / \mathrm{lb}$, ash content of less 10 percent and pyritic sulphur removal of up to 95 percent.

Based on the tests pertormed, design specifications were defined for the conceptual design of a 2.8 million ton Aglofloat plant. The specifications in- 
cluded a relatively high amount of bridging oil (12 percent d.a.f. feed coal basis) in order to obtain 0.8 to $3.0 \mathrm{~mm}$ agglomerates. More research on the IATF is, therefore, recommended in order to recuce the amount of oil used in the process. Recommended research includes:

- Investigation of the relationship between feed size, feed properties, and product quality, at different oil additions.

- Improvement of floatation and pyrite separation efficiency, at high solid slurry loading.

- Development of better control strategies for different feeds.

- Evaluation of the Aglofloat process configurations where size enlargement by agglomeration is eliminated and other options to size enlargement are considered.

\section{Feaslbility of the Aglonoat Process}

A conceptual design for the Aglofloat plant was developed for beneficiating 2.8 million tons of ROM bituminous coal per year to 2.74 million tons of agglomerates with a heating value of $13,300 \mathrm{Btu} / \mathrm{b}$, ash content of 6.2 percent and sulphur content of 2.5 percent. The economic analyses of the plant cost estimated the Capital Cost at $\$ 61,978,000$,
Operating Cost at $\$ 121,056,000$ and Working Capital at $\$ 22,155,000$. The Product Cost was estimated at $\$ 52.85$ per ton at DCF ROR equal to 15 percent (after tax).

The Product Cost was sensitive to the cost of coal, to the cost and quantity of bridging oil, and to a lesser extent, to Capital and Operating Cost (excluding coal).

For variance case, where Aglofloat is applied to cleaning coal refuse, the Product Cost was estimated at \$25.26n. This cost is competitive with the average cost for low and medium sulphur coal in the eastern U.S. of $\$ 20$ to $\$ 28$ per ton.

Recommended future work on the conceptual design of the Aglofloat process includes:

- Updating of the design and costing of the process areas based on additional experimental work pertormed at the Integrated Agglomeration Test Facility.

- Evaluation of the process design and area costing for altemative size enlargement process options in the Aglofloat process.

- Review of the economic feasibility and market potential of the Aglofloat process for the updated process designs. 


\section{References}

Franzidis, J.P. and Harris, M.C., "A New Method for the Rapid Float-Sink Analysis of Coal Fines," Journal of the South African Institute of Mining and Metallurgy. 86, (10), 409-414, 1989.

Pawlak, W., Goddard, R., Janiak, J., Turak, A., and Ignasiak, B., Oil Agglomeration of Low Rank Coals. Paper presented at the Clean Liquid and Solid Fuels Contractor's Conference, Palo Atto, California, April 23-25, 1985.

Schubert, H., Tensile Strength and Capillary Pressure of Moist Agglomerates. Proc. 2nd Int. Symp. on Agglomeration (K.V.S. Sastry, ed.),
Agglomeration 77, AlME, New York 1977, pp. 144-155.

Szymocha, K., Pawlak, W., and Ignasiak, B., Kinetics of Oil Agglomeration of Coal at Extended Agitation Times. ICHEME 5th International Symposium on Agglomeration. Brighton, England, September 25-27, 525-536. (1989). Tanaka, T., Ouchiyama N., Coordination Numbers and Porosity of Packing Calculated from Particle Size Distribution, 4th Int. Symposium on Agglomeration pp. 9-16, 1985. 
Ms. Gabriella Teodosiu

ONTARIO MINISTRY OF ENERGY

11th Floor

56 Wellesley Street West

Toronto, Ontario

M7A 2B7

Mr. Jack Lawrence

V.P. Engineering

ONTARIO OHIO SYNTHETIC FUEL CORP.

1 Eva Rd., Suite 310

Elobicoke, Ontario

M9C 425

Mr. A. Patel

PANCANADIAN PETROLEUM LIMITED

PanCanadian Plaza

P.O. Box 2850

Calgany, Alberta

T2P 255

Mr. Gonzalo Mon

Manager, Env. \& Prod. Support

PUBLIC SERVICE ELECTRIC \& GAS CO.

Mail Stop - 15-A

P.O. Box 570

Newark, NJ 07101

U.S.A.

Ms. Betty Jensen

PUBLIC SERVICE ELECTRIC \& GAS CO.

Mail Stop - 15-A

P.O. Box 570

Newark, NW 07101

U.S.A.

Mr. J. Barrett Chovalier

THERMO DESIGN ENGINEERING LTD.

P.O. Box 5557

Postal Station L

Edmonton, Aberta

T6C 4E9

Mr. Antoni Rojek

THERMO DESIGN ENGINEERING LTD.

P.O. Box 5557

Postal Station L

Edmonton, Aberta

T6C 4E9
Mr. Richard Hucko

DEPARTMENT OF ENERGY

Pittsburg, Energy Technology Center

P.O. Box 10940

Pittsburgh, PA 15236-0940

U.S.A.

Mr. Eugene Honeycult

DRUMMOND COAL CO., INC.

Coal Preparation

P.O. Box 1549

Jasper, AL 35502-1549

U.S.A.

Ms. Debra DiMeo

ESEERCO

1155 Avenue of the Americas

New York, NY 10036

U.S.A.

Mr. Dwain Weckman

ESSO RESOURCES CANADA LIMITED

Esso Plaza East Tower

237 Fourth Avenue Southwest

Calgary, Aberta

T2P 0 H6

Mr. Colin Mckenny

FORDING COAL LIMITED

\#200 - 205 Ninth Avenue S.E.

Calgary, Alberta

T2G OR4

Mr. Ron Klattenberg

NORTHEAST UTILITIES

P.O. BOX 270

Hartiond, CT 06101

U.S.A.

Mr. Bob Goodrich

NORTHEAST UTILITIES

P.O. BOX 270

Hartiond, CT 06101

U.S.A.

Mr. Geiry Pangrace

OBED MOUNTAIN COAL COMPANY LTD.

P.O. Box 7600

Himton, Aberta

TOE 1BO

Mr. Blair Sockington 
ONTARIO HYDRO

700 University Ave.

Toronto, Ontario

M5G $1 \times 6$

Mr. Arvid Hardin

ALBERTA RESEARCH COUNCIL

Coal Research Dept.

P.O. Bag 1310

One Oil Patch Drive

Devon, Alberta

TOC $1 E 0$

Or. Leszek Ignasiak

ALBERTA RESEARCH COUNCIL

Coal Research Dept.

P.O. Bag 1310

One Oil Patch Drive

Devon, Alberta

TOC 1EO

Ms. Ray Gilani

CONSOLIDATED EDISON $C O$.

4 Inving Place

New York, NY 10003

U.S.A.

Dr. William Wells

CENTER FOR RESEARCH ON SULFUR IN COAL

R.R. \#2, Coal Development Park

Suite 200

Carterville, IL 62918

U.S.A.

Mr. Ken Ho

CENTER FOR RESEARCH ON SULFUR IN COAL

R.R. \#2, Coal Development Park

Suite 200

Carterville, IL 62918-

U.S.A.
Mr. Tom Feely

DEPARTMENT OF ENERGY

Pittsburgh Energy Technology Center

P.O. Box 10940

Pittsburg, PA 15236-0940

U.S.A.

Mr. Makolm McDonald

TRANSALTA UTILITIES CORP.

110 - 12th Avenue, S.W.

Box 1900

Calgary, Aberta

T2P 2M1

Mr. Theodore C. Frankiewicz

Unocal Science \& Technology Division

UNOCAL CORP.

376 South Valencia Ave.

P.O. Box 76

Brea, CA 92621

U.S.A.

Mr. Gary Daigle

YANKEE GAS SERVICE CO.

999 West Street

Rocky Hill, CT 06067-4002

U.S.A.

Ms. Jill Higgins

CONFERENCE COORDINATOR

883 Santa Cruz Ave., Suite 30

Menio Park, CA 94025

U.S.A. 


\section{Appendix 2.}

Table N21. Properties of bituminous coals tested.

\begin{tabular}{|c|c|c|c|c|c|c|c|c|c|}
\hline & $\begin{array}{c}\text { DOE } \\
\text { Supplbe } \\
\text { III. } \\
\text { No. } 6\end{array}$ & $\begin{array}{l}\text { III. } \\
\text { No. } 6\end{array}$ & Onlo & Pltts. & $\underset{V}{\text { Indiana }}$ & $\begin{array}{l}\text { Upper } \\
\text { Fresport }\end{array}$ & $\begin{array}{l}\text { Byron } \\
\text { Creek }\end{array}$ & $\begin{array}{l}\text { Obed } \\
\text { Washed }\end{array}$ & $\begin{array}{l}\text { Obed } \\
\text { Preclp. } \\
\text { Dust }\end{array}$ \\
\hline $\begin{array}{l}\text { Moisture } \\
\text { Ash } \\
\text { Volatil Matter } \\
\text { Fixed Carbon } \\
\text { Total Sulphur } \\
\text { Pyritic Sulphur }\end{array}$ & $\begin{array}{l}14.3 \\
\overline{-} \\
4.27 \\
1.98\end{array}$ & $\begin{array}{l}34.8 \\
28.8 \\
36.4 \\
4.19 \\
2.33\end{array}$ & $\begin{array}{l}9.2 \\
\overline{-} \\
4.72 \\
2.94\end{array}$ & $\begin{array}{l}17.7 \\
\overline{-} \\
4.98 \\
2.70\end{array}$ & $\begin{array}{l}9.7 \\
- \\
3.77 \\
1.83\end{array}$ & $\begin{array}{c}12.3 \\
\overline{-} \\
2.33 \\
1.37\end{array}$ & $\begin{array}{c}24.5 \\
21.9 \\
22.1 \\
56.1 \\
0.30 \\
-\end{array}$ & $\begin{array}{c}8.5 \\
14.2 \\
36.2 \\
49.5 \\
0.51 \\
-\end{array}$ & $\begin{array}{c}10.5 \\
27.7 \\
32.6 \\
39.7 \\
- \\
-\end{array}$ \\
\hline Heating Value & 11,980 & 8,350 & 12,390 & 11,960 & 13,270 & 13,560 & 11,530 & 10,510 & 8,140 \\
\hline
\end{tabular}

on moist basis. 
Tablo A3.1. Pyrite removal process performanco - Test Data, Run No. D3.

\begin{tabular}{|c|c|c|c|c|c|c|c|c|c|c|c|c|c|c|c|}
\hline \multirow{2}{*}{$\begin{array}{l}\text { Run } \\
\text { Per. }\end{array}$} & \multirow[b]{2}{*}{$\begin{array}{c}\text { Oll } \\
\text { cona } \\
d b \\
x\end{array}$} & \multicolumn{4}{|c|}{ Sample A (S-140) } & \multicolumn{4}{|c|}{ Sample B (S-201) } & \multicolumn{4}{|c|}{$\begin{array}{c}\text { Samplo C (S-S01) } \\
\text { (S-221) }\end{array}$} & & \multirow[b]{2}{*}{$\underset{\text { Recov }}{\text { Coal }}$} \\
\hline & & $\hat{\boldsymbol{A}}$ & $\begin{array}{c}\text { Parent c } \\
\text { Ts } \\
\% \\
\end{array}$ & $\begin{array}{l}\text { Oal (dt } \\
\text { PS } \\
\% \\
\end{array}$ & $\begin{array}{l}\text { ss } \\
\%\end{array}$ & $\hat{x}$ & $\begin{array}{l}\text { Coal } \\
\text { TS } \\
\%\end{array}$ & $\begin{array}{l}\text { slurry } \\
\text { PS } \\
\%\end{array}$ & $\begin{array}{l}\text { ss } \\
\text { \% }\end{array}$ & $\hat{\mathbf{A}}$ & $\begin{array}{l}\text { Pro } \\
\text { Ts } \\
\%\end{array}$ & $\begin{array}{c}\text { duct } \\
\text { dus } \\
\%\end{array}$ & $\begin{array}{l}\text { SS } \\
\%\end{array}$ & $\begin{array}{l}\text { Sulphur } \\
\text { Romoval } \\
\text { ATS } \Delta \text { PS } \\
\% \quad \%\end{array}$ & \\
\hline $\begin{array}{l}\mathbf{A} \\
\mathbf{8} \\
\mathbf{C} \\
\mathbf{D}\end{array}$ & $\begin{array}{l}3.0 \\
2.9 \\
2.8 \\
2.3\end{array}$ & $\begin{array}{l}34.1 \\
34.5 \\
33.8 \\
33.3\end{array}$ & $\begin{array}{l}4.65 \\
4.84 \\
5.24 \\
4.95 \\
\end{array}$ & $\begin{array}{l}2.53 \\
2.53 \\
2.53 \\
2.53\end{array}$ & $\begin{array}{l}0.37 \\
0.37 \\
0.37 \\
0.37\end{array}$ & $\begin{array}{l}30.5 \\
30.9 \\
30.9 \\
31.8\end{array}$ & $\begin{array}{l}4.37 \\
4.33 \\
4.50 \\
5.02\end{array}$ & $\begin{array}{l}1.70 \\
1.75 \\
2.17 \\
2.33\end{array}$ & $\begin{array}{l}0.09 \\
0.21 \\
0.22 \\
0.12\end{array}$ & $\begin{array}{l}11.8 \\
14.1 \\
14.7 \\
14.8\end{array}$ & $\begin{array}{l}4.25 \\
4.33 \\
4.50 \\
5.02\end{array}$ & $\begin{array}{l}1.70 \\
1.75 \\
2.17 \\
2.33\end{array}$ & $\begin{array}{l}0.09 \\
0.21 \\
0.22 \\
0.12\end{array}$ & $\begin{array}{ll}29.0 & 82.9 \\
23.2 & 61.4 \\
20.6 & 58.6 \\
21.7 & 78.2\end{array}$ & $\begin{array}{l}87.6 \\
88.5 \\
89.0 \\
87.0\end{array}$ \\
\hline
\end{tabular}

Tablo A3.1. Pyrite removal process porformance - Test Data, Run No. D3 (cont'd).

\begin{tabular}{|c|c|c|c|c|c|c|c|c|c|c|}
\hline \multirow[t]{2}{*}{$\begin{array}{l}\text { Run } \\
\text { Pur. }\end{array}$} & \multirow{2}{*}{$\begin{array}{c}\text { Oll } \\
\text { cona } \\
d b \\
x\end{array}$} & \multicolumn{4}{|c|}{$\begin{array}{c}\text { Sample D (S401) } \\
\text { Product D }\end{array}$} & \multicolumn{4}{|c|}{$\begin{array}{c}\text { Ash Sulphur } \\
\text { Promoval }\end{array}$} & \multirow{2}{*}{$\begin{array}{c}\text { Coal } \\
\text { Accovery } \\
\%\end{array}$} \\
\hline & & $\begin{array}{l}\mathbf{A} \\
\mathbf{\%}\end{array}$ & $\begin{array}{l}\text { Ts } \\
\% \\
\end{array}$ & $\begin{array}{l}\text { PS } \\
\times\end{array}$ & $\begin{array}{l}\text { ss } \\
\%\end{array}$ & $\begin{array}{l}\Delta \mathbf{A} \\
\mathbf{x}\end{array}$ & $\begin{array}{c}\Delta \mathrm{TS} \\
\mathrm{x}\end{array}$ & $\underset{\%}{\Delta P S}$ & $\begin{array}{c}\Delta \mathbf{S S} \\
\%\end{array}$ & \\
\hline $\begin{array}{l}\mathbf{A} \\
\mathbf{B} \\
\mathrm{C} \\
\mathrm{D}\end{array}$ & $\begin{array}{l}3.0 \\
2.9 \\
2.8 \\
2.3\end{array}$ & \begin{tabular}{r|}
9.47 \\
10.72 \\
10.96 \\
10.41 \\
\end{tabular} & $\begin{array}{l}4.04 \\
5.53 \\
4.51 \\
4.60\end{array}$ & $\begin{array}{l}1.48 \\
1.83 \\
1.85 \\
1.88\end{array}$ & $\begin{array}{l}0.04 \\
0.07 \\
0.04 \\
0.04\end{array}$ & $\begin{array}{l}82.3 \\
84.1 \\
83.4 \\
85.6\end{array}$ & $\begin{array}{l}44.3 \\
45.0 \\
49.7 \\
51.2\end{array}$ & $\begin{array}{l}66.3 \\
61.0 \\
59.4 \\
62.1\end{array}$ & $\begin{array}{l}69.8 \\
65.2 \\
63.3 \\
66.2\end{array}$ & $\begin{array}{l}75.3 \\
75.8 \\
76.4 \\
72.4\end{array}$ \\
\hline
\end{tabular}

Table A3.2 Pyrite removal process performance - Test Data, Run No. D4.

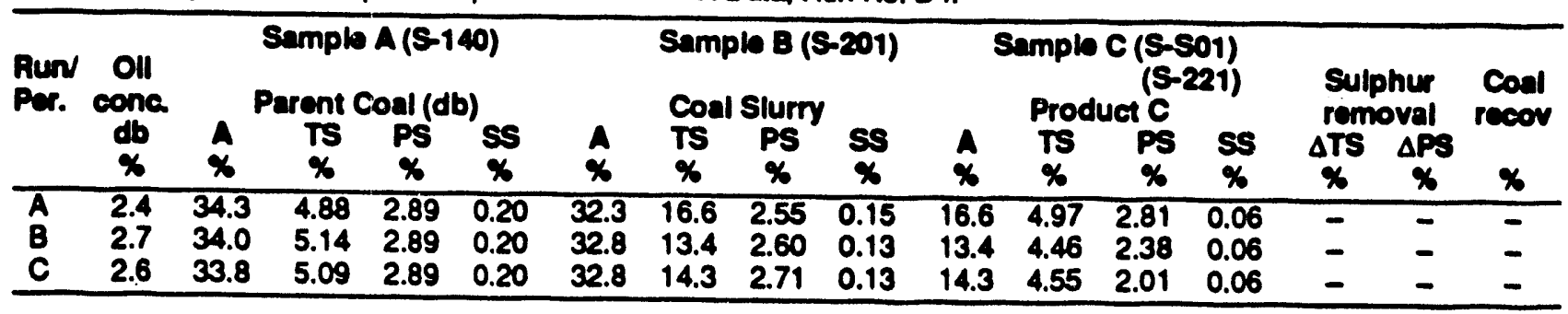

Table A3.2. Pyrite removal process pertormanco - Test Data, Run No. D4 (cont'd).

\begin{tabular}{|c|c|c|c|c|c|c|c|c|c|c|}
\hline \multirow{2}{*}{\multicolumn{2}{|c|}{$\begin{array}{l}\text { Run Oll } \\
\text { Pur. cona } \\
\text { db } \\
x\end{array}$}} & \multicolumn{4}{|c|}{$\begin{array}{l}\text { Sample D (S401) } \\
\text { Product D }\end{array}$} & \multicolumn{4}{|c|}{$\begin{array}{l}\text { Ash and sulphur } \\
\text { removal }\end{array}$} & \multirow{2}{*}{$\begin{array}{c}\text { Coal } \\
\text { recovery } \\
\% \\
\end{array}$} \\
\hline & & $\stackrel{A}{x}$ & $\begin{array}{l}\text { Ts } \\
\times\end{array}$ & $\stackrel{p S}{*}$ & $\begin{array}{l}s s \\
\times\end{array}$ & $\stackrel{\Delta}{x}$ & $\underset{x}{\Delta r s}$ & $\triangle \mathrm{PS}$ & $\underset{\mathbf{A S S}}{\mathrm{H}}$ & \\
\hline $\begin{array}{l}A \\
B \\
C\end{array}$ & $\begin{array}{l}2.4 \\
2.7 \\
2.6\end{array}$ & $\begin{array}{r}9.30 \\
10.20 \\
9.60\end{array}$ & $\begin{array}{l}3.85 \\
4.25 \\
3.90\end{array}$ & $\begin{array}{l}1.33 \\
1.68 \\
1.61\end{array}$ & $\begin{array}{l}0.05 \\
0.05 \\
0.05\end{array}$ & $\begin{array}{l}89.7 \\
85.5 \\
85.3\end{array}$ & $\begin{array}{l}70.0 \\
60.1 \\
60.6\end{array}$ & $\begin{array}{l}82.5 \\
72.3 \\
71.3\end{array}$ & $\begin{array}{l}81.9 \\
72.4 \\
71.5\end{array}$ & $\begin{array}{l}52.5 \\
65.6 \\
70.5\end{array}$ \\
\hline
\end{tabular}

Tablo A3.3. Pyrite remoyal procoss pertormance - Test Data, Run No. D6.

\begin{tabular}{|c|c|c|c|c|c|c|c|c|c|c|c|c|c|c|c|c|}
\hline \multirow{2}{*}{$\begin{array}{l}\text { Run } \\
\text { Per. }\end{array}$} & \multirow{2}{*}{$\begin{array}{c}\text { Oll } \\
\text { conca } \\
\text { to } \\
x\end{array}$} & \multicolumn{4}{|c|}{ Sampio A (S-140) } & \multicolumn{4}{|c|}{ Samplo B (S-201) } & \multicolumn{4}{|c|}{$\begin{array}{r}\text { Samplo C (S-S01) } \\
(S-221)\end{array}$} & & \multirow[b]{2}{*}{$\begin{array}{c}\text { Coal } \\
\text { Recor } \\
x\end{array}$} \\
\hline & & $\hat{\mathbf{x}}$ & $\begin{array}{c}\text { Parent } \\
\text { Ts } \\
\%\end{array}$ & $\begin{array}{c}\text { oal (d) } \\
\text { PS } \\
x\end{array}$ & $\begin{array}{l}\text { b) } \\
\mathrm{x}\end{array}$ & $\hat{\boldsymbol{A}}$ & $\begin{array}{c}\text { Coal } \\
\text { TS } \\
\%\end{array}$ & $\begin{array}{l}\text { Slurry } \\
\text { PS } \\
\%\end{array}$ & & $\hat{\mathbf{A}}$ & $\begin{array}{l}\text { Prod } \\
\text { Ts } \\
\%\end{array}$ & $\begin{array}{r}\text { Det C } \\
\text { PS }\end{array}$ & $\begin{array}{l}5 s \\
\%\end{array}$ & $\begin{array}{c}\text { Rom } \\
\text { ATs }\end{array}$ & $\begin{array}{c}\text { oval } \\
\text { Aps }\end{array}$ & \\
\hline $\begin{array}{l}A \\
B \\
C \\
D \\
E\end{array}$ & $\begin{array}{l}\overline{-} \\
\bar{z} \\
\bar{z}\end{array}$ & $\begin{array}{l}32.7 \\
32.7 \\
32.7 \\
32.7 \\
32.7 \\
32.7\end{array}$ & $\begin{array}{l}51.8 \\
51.8 \\
51.8 \\
51.8 \\
51.8 \\
51.8\end{array}$ & $\begin{array}{l}2.72 \\
2.72 \\
2.72 \\
2.72 \\
2.72 \\
2.72\end{array}$ & $\begin{array}{l}0.35 \\
0.35 \\
0.35 \\
0.35 \\
0.35 \\
0.35\end{array}$ & $\begin{array}{c}3 \overline{4} .6 \\
35.6 \\
34.9 \\
35.8 \\
-\end{array}$ & $\begin{array}{c}-\overline{4} \\
4.65 \\
4.53 \\
4.82 \\
-\end{array}$ & $\begin{array}{c}-\overline{19} \\
2.40 \\
2.36 \\
2.39 \\
-\end{array}$ & $\begin{array}{l}-\overline{45} \\
0.46 \\
0.46 \\
0.44 \\
-\end{array}$ & $\begin{array}{c}- \\
15.2 \\
15.4 \\
15.6 \\
15.4 \\
-\end{array}$ & $\begin{array}{l}4 . \overline{93} \\
4.81 \\
4.84 \\
4.27 \\
-\end{array}$ & $\begin{array}{c}-\overline{93} \\
2.03 \\
2.57 \\
1.75 \\
-\end{array}$ & $\begin{array}{c}- \\
0.17 \\
0.16 \\
0.16 \\
0.15 \\
-\end{array}$ & $\begin{array}{l}51.1 \\
34.2 \\
34.5 \\
32.9 \\
33.4 \\
39.8\end{array}$ & $\begin{array}{c}-\overline{-} \\
51.8 \\
51.6 \\
37.4 \\
52.4 \\
-\end{array}$ & $\begin{array}{l}82.4 \\
85.9 \\
84.0 \\
85.1 \\
85.0 \\
82.9\end{array}$ \\
\hline
\end{tabular}


Thbl A3.3. Pyite removal procases pertormance - Test Data, Run No. D6 (cont'd).

\begin{tabular}{|c|c|c|c|c|c|c|c|c|c|c|}
\hline \multirow{2}{*}{\multicolumn{2}{|c|}{$\begin{array}{l}\text { Pun of } \\
\text { Per. ocone } \\
x \\
x\end{array}$}} & \multicolumn{4}{|c|}{$\begin{array}{l}\text { Samplo D (SAO1) } \\
\text { Product D }\end{array}$} & \multicolumn{4}{|c|}{$\begin{array}{l}\text { Ach and sulphur } \\
\text { removal }\end{array}$} & \multirow{2}{*}{$\begin{array}{c}\text { Coal } \\
\text { recovery } \\
\%\end{array}$} \\
\hline & & $\stackrel{A}{x}$ & $\begin{array}{l}\text { Ts } \\
\times\end{array}$ & Ps & $\stackrel{s s}{*}$ & $\mathbf{u}$ & $\underset{*}{\Delta T S}$ & $\underset{X}{\triangle P B}$ & $\underset{\%}{\Delta s s}$ & \\
\hline $\begin{array}{l}\mathbf{A} \\
\mathbf{B} \\
\mathbf{C} \\
\mathbf{D} \\
\mathbf{E} \\
\mathrm{F}\end{array}$ & $\begin{array}{l}\bar{z} \\
\bar{z} \\
\bar{z}\end{array}$ & $\begin{array}{r}9.30 \\
9.90 \\
9.95 \\
9.80 \\
10.07 \\
10.59\end{array}$ & $\begin{array}{l}3.91 \\
3.94 \\
4.11 \\
4.10 \\
4.21 \\
4.12\end{array}$ & $\begin{array}{l}1.10 \\
1.12 \\
1.34 \\
1.19 \\
1.29 \\
1.45\end{array}$ & $\begin{array}{l}0.12 \\
0.17 \\
0.15 \\
0.18 \\
0.15 \\
0.09\end{array}$ & $\begin{array}{l}84.3 \\
82.5 \\
85.0 \\
83.4 \\
83.6 \\
82.6\end{array}$ & $\begin{array}{l}60.0 \\
46.5 \\
48.3 \\
48.2 \\
49.0 \\
61.6\end{array}$ & $\begin{array}{l}77.7 \\
75.9 \\
73.7 \\
75.0 \\
21.6 \\
77.0\end{array}$ & $\begin{array}{l}78.1 \\
75.4 \\
74.1 \\
74.4 \\
73.6 \\
78.2\end{array}$ & $\begin{array}{l}74.4 \\
78.9 \\
74.5 \\
78.1 \\
77.5 \\
73.0\end{array}$ \\
\hline
\end{tabular}

Treb A3.4. Pyrito removal procases pertormances - Teat Data, Run No. D7.

\begin{tabular}{|c|c|c|c|c|c|c|c|c|c|c|c|c|c|c|c|c|}
\hline \multirow{2}{*}{$\begin{array}{l}\text { Mur } \\
\text { Px. }\end{array}$} & \multirow[b]{2}{*}{$\begin{array}{c}\infty \\
\infty \\
x \\
\infty\end{array}$} & \multirow{2}{*}{\multicolumn{4}{|c|}{$\begin{array}{l}\text { Samplo A(S-140) } \\
\text { Parem Coal }(d b)\end{array}$}} & \multicolumn{4}{|c|}{$\begin{array}{l}\text { Samplo B (S-201) } \\
\text { coal Sumy }\end{array}$} & \multicolumn{4}{|c|}{$\begin{array}{c}\text { Samplo C (S-S01) } \\
\text { (S-221) } \\
\text { Product C }\end{array}$} & \multirow{2}{*}{\multicolumn{2}{|c|}{$\begin{array}{l}\text { Sulphur } \\
\text { Romoval }\end{array}$}} & \multirow[b]{2}{*}{$\begin{array}{c}\text { Coul } \\
\text { Recor } \\
\times\end{array}$} \\
\hline & & & & & & $\mathbf{A}$ & $\underset{\pi}{\text { Coal }}$ & $\underset{x}{p 8}$ & $\begin{array}{l}83 \\
x\end{array}$ & $\hat{x}$ & $\begin{array}{l}\text { Prodk } \\
\text { Ts }\end{array}$ & $\underset{\%}{p}$ & $\begin{array}{l}\text { si) } \\
x\end{array}$ & & & \\
\hline $\begin{array}{l}A \\
B \\
C \\
D \\
E\end{array}$ & $\begin{array}{l}\bar{z} \\
\bar{z} \\
\bar{z}\end{array}$ & $\begin{array}{l}32.7 \\
32.7 \\
32.7 \\
32.7 \\
32.7\end{array}$ & $\begin{array}{l}5.18 \\
5.18 \\
5.18 \\
5.18 \\
5.18\end{array}$ & $\begin{array}{l}2.72 \\
2.72 \\
2.72 \\
2.72 \\
2.72\end{array}$ & $\begin{array}{l}0.36 \\
0.36 \\
0.35 \\
0.35 \\
0.35\end{array}$ & $\begin{array}{l}32.2 \\
31.8 \\
32.6 \\
31.6\end{array}$ & $\begin{array}{l}4 . \overline{78} \\
4.70 \\
4.74 \\
4.81\end{array}$ & $\begin{array}{l}-\overline{-56} \\
2.65 \\
2.62 \\
2.48\end{array}$ & $\begin{array}{l}0 . \overline{35} \\
0.32 \\
0.35 \\
0.38\end{array}$ & $\begin{array}{l}1 \overline{15.6} \\
14.3 \\
15.8 \\
16.1\end{array}$ & $\begin{array}{l}-\overline{79} \\
4.60 \\
4.77 \\
4.73\end{array}$ & $\begin{array}{l}2 . \overline{24} \\
2.04 \\
2.31 \\
2.48\end{array}$ & $\begin{array}{l}0.14 \\
0.17 \\
0.17 \\
0.18\end{array}$ & $\begin{array}{l}45.1 \\
32.2 \\
33.1 \\
32.7 \\
32.7\end{array}$ & $\begin{array}{l}4 \overline{6} .7 \\
51.8 \\
45.6 \\
40.6\end{array}$ & $\begin{array}{l}81.0 \\
83.9 \\
83.8 \\
84.1 \\
84.6\end{array}$ \\
\hline $\begin{array}{l}\mathbf{F} \\
\mathbf{G} \\
\mathbf{H}\end{array}$ & $\overline{-}$ & $\begin{array}{l}32.7 \\
32.7 \\
32.7\end{array}$ & $\begin{array}{l}5.18 \\
5.18 \\
5.18\end{array}$ & $\begin{array}{l}2.72 \\
2.72 \\
2.72 \\
\end{array}$ & $\begin{array}{l}0.35 \\
0.35 \\
0.35\end{array}$ & $\overline{-}$ & $\overline{-}$ & $\overline{-}$ & $\bar{z}$ & $\overline{-}$ & $\overline{-}$ & $\overline{-}$ & $\overline{-}$ & $\begin{array}{l}32.8 \\
34.5 \\
28.6\end{array}$ & $\overline{-}$ & $\begin{array}{l}84.8 \\
83.5 \\
87.5\end{array}$ \\
\hline
\end{tabular}

Tebs A34.4 Pyrite removal procenes pertormance - Teet Data, Run No. O7 (cont'd).

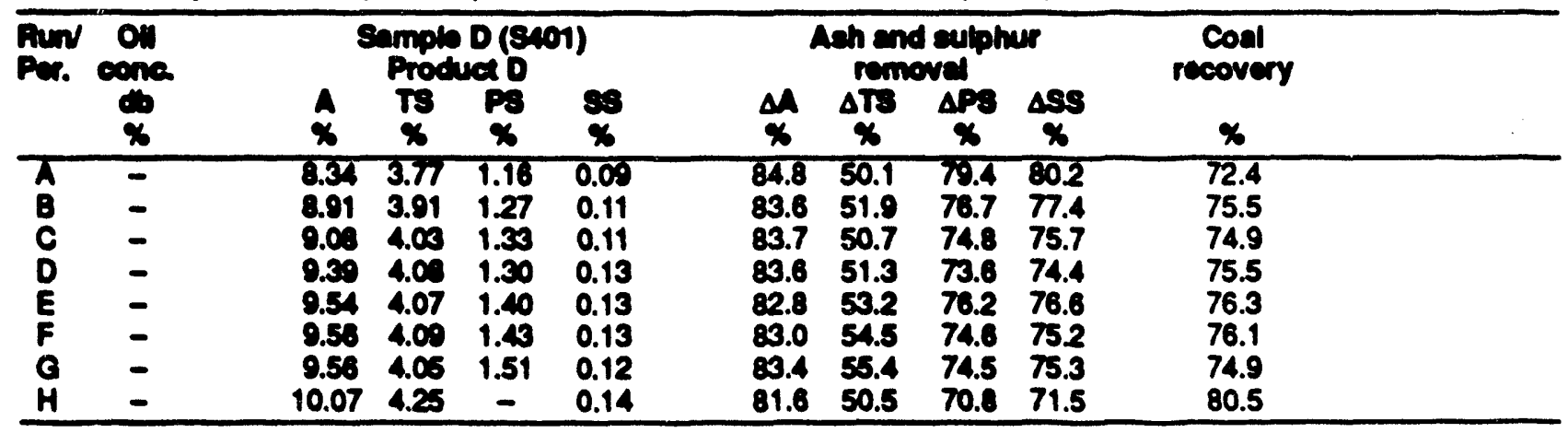


Table A3.5. Pyrite removal process pertormanco - Test Data, Run No. D9.

\begin{tabular}{|c|c|c|c|c|c|c|c|c|c|c|c|c|c|c|c|c|}
\hline \multirow{2}{*}{$\begin{array}{l}\text { Run/ } \\
\text { Por. }\end{array}$} & \multirow[b]{2}{*}{$\begin{array}{c}\text { Oll } \\
\text { conc. } \\
\text { db } \\
\%\end{array}$} & \multicolumn{4}{|c|}{ Sample A (S-140) } & \multicolumn{4}{|c|}{ Sample B (S-201) } & \multicolumn{4}{|c|}{$\begin{array}{r}\text { Sample C (S-S01) } \\
\text { (S-221) }\end{array}$} & & \multirow[b]{2}{*}{$\begin{array}{c}\text { Coal } \\
\text { Rocov } \\
\%\end{array}$} \\
\hline & & $\begin{array}{c}\mathbf{A} \\
\mathbf{X}\end{array}$ & $\begin{array}{c}\text { arent } \\
\text { Ts } \\
\%\end{array}$ & $\begin{array}{c}\text { Coll (dI } \\
\text { PS } \\
\% \\
\end{array}$ & $\begin{array}{l}\text { ss } \\
\text { \% }\end{array}$ & $\stackrel{A}{*}$ & $\begin{array}{c}\text { Coal } \\
\text { TS } \\
\%\end{array}$ & $\begin{array}{l}\text { Slurry } \\
\text { PS } \\
\%\end{array}$ & & $\hat{x}$ & $\begin{array}{l}\text { Prodt } \\
\text { TS } \\
x\end{array}$ & $\begin{array}{c}1 \text { C-2 } \\
\text { PS } \\
\%\end{array}$ & & $\begin{array}{c}\text { Sul } \\
\text { Rem } \\
\text { DTs } \\
\psi_{n}\end{array}$ & $\begin{array}{c}\text { ovur } \\
\text { oval } \\
\triangle P S \\
\%\end{array}$ & \\
\hline $\begin{array}{l}\bar{A} \\
B \\
C\end{array}$ & $\begin{array}{l}2.2 \\
2.2 \\
2.2 \\
2.2\end{array}$ & $\begin{array}{l}32.3 \\
32.3 \\
32.3 \\
32.3 \\
\end{array}$ & $\begin{array}{l}5.18 \\
5.18 \\
5.18 \\
5.18\end{array}$ & $\begin{array}{l}.72 \\
2.72 \\
2.72 \\
2.72\end{array}$ & $\begin{array}{l}0.35 \\
0.35 \\
0.35 \\
0.35\end{array}$ & $\begin{array}{l}30.3 \\
31.4 \\
31.5 \\
30.4\end{array}$ & $\begin{array}{l}4.98 \\
5.06 \\
4.88 \\
4.80\end{array}$ & $\begin{array}{l}2.27 \\
2.57 \\
2.55 \\
2.58\end{array}$ & $\therefore$ & $\begin{array}{l}14.3 \\
13.0 \\
14.7 \\
13.9\end{array}$ & $\begin{array}{l}4.54 \\
4.47 \\
4.92 \\
4.61\end{array}$ & $\begin{array}{l}1.79 \\
1.61 \\
1.85 \\
2.16\end{array}$ & $\begin{array}{l}0.08 \\
0.07 \\
0.08 \\
0.08\end{array}$ & $\begin{array}{l}38.6 \\
37.7 \\
26.5 \\
25.2\end{array}$ & $\begin{array}{l}16.9 \\
55.7 \\
47.1 \\
34.8\end{array}$ & $\begin{array}{l}76 \\
82 \\
82 \\
86\end{array}$ \\
\hline
\end{tabular}

Table A3.5. Pyrite removal process pertormance - Test Data, Run No. D9 (cont'd).

\begin{tabular}{|c|c|c|c|c|c|c|c|c|c|c|}
\hline \multirow{2}{*}{$\begin{array}{l}\text { Run } \\
\text { Per. }\end{array}$} & \multirow{2}{*}{$\begin{array}{c}\text { Oll } \\
\text { cona } \\
d b \\
x\end{array}$} & \multicolumn{4}{|c|}{$\begin{array}{l}\text { Sample D (S401) } \\
\text { Product D }\end{array}$} & \multicolumn{4}{|c|}{$\begin{array}{l}\text { Ash and sulphur } \\
\text { removal }\end{array}$} & \multirow{2}{*}{$\begin{array}{c}\text { Coal } \\
\text { recovery } \\
\% \\
\end{array}$} \\
\hline & & $\hat{\mathbf{A}}$ & $\begin{array}{l}\text { Prod } \\
\text { TS } \\
\% \\
\end{array}$ & $\begin{array}{l}\text { set D } \\
\text { PS } \\
\times \\
\end{array}$ & $\begin{array}{l}\text { ss } \\
\%\end{array}$ & $\underset{\chi_{0}}{\Delta A}$ & 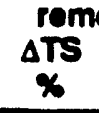 & $\begin{array}{c}\text { val } \\
\triangle \text { PS } \\
\text { \% }\end{array}$ & $\underset{\%}{\Delta S S}$ & \\
\hline $\begin{array}{l}\text { A } \\
\text { B } \\
C \\
D\end{array}$ & $\begin{array}{l}2.2 \\
2.2 \\
2.2 \\
2.2\end{array}$ & $\begin{array}{r}9.4 \\
9.4 \\
10.6 \\
10.2\end{array}$ & $\begin{array}{l}3.95 \\
3.94 \\
4.10 \\
4.20 \\
\end{array}$ & $\begin{array}{l}1.11 \\
1.09 \\
1.36 \\
1.29\end{array}$ & $\begin{array}{l}0.06 \\
0.05 \\
0.06 \\
0.06\end{array}$ & $\begin{array}{l}84.7 \\
83.9 \\
81.3 \\
81.4\end{array}$ & $\begin{array}{l}52.9 \\
53.9 \\
48.6 \\
48.8\end{array}$ & $\begin{array}{l}78.6 \\
77.8 \\
71.5 \\
72.0\end{array}$ & $\begin{array}{l}80.0 \\
79.5 \\
73.6 \\
74.1\end{array}$ & $\begin{array}{l}67.2 \\
67.8 \\
74.5 \\
74.2\end{array}$ \\
\hline
\end{tabular}

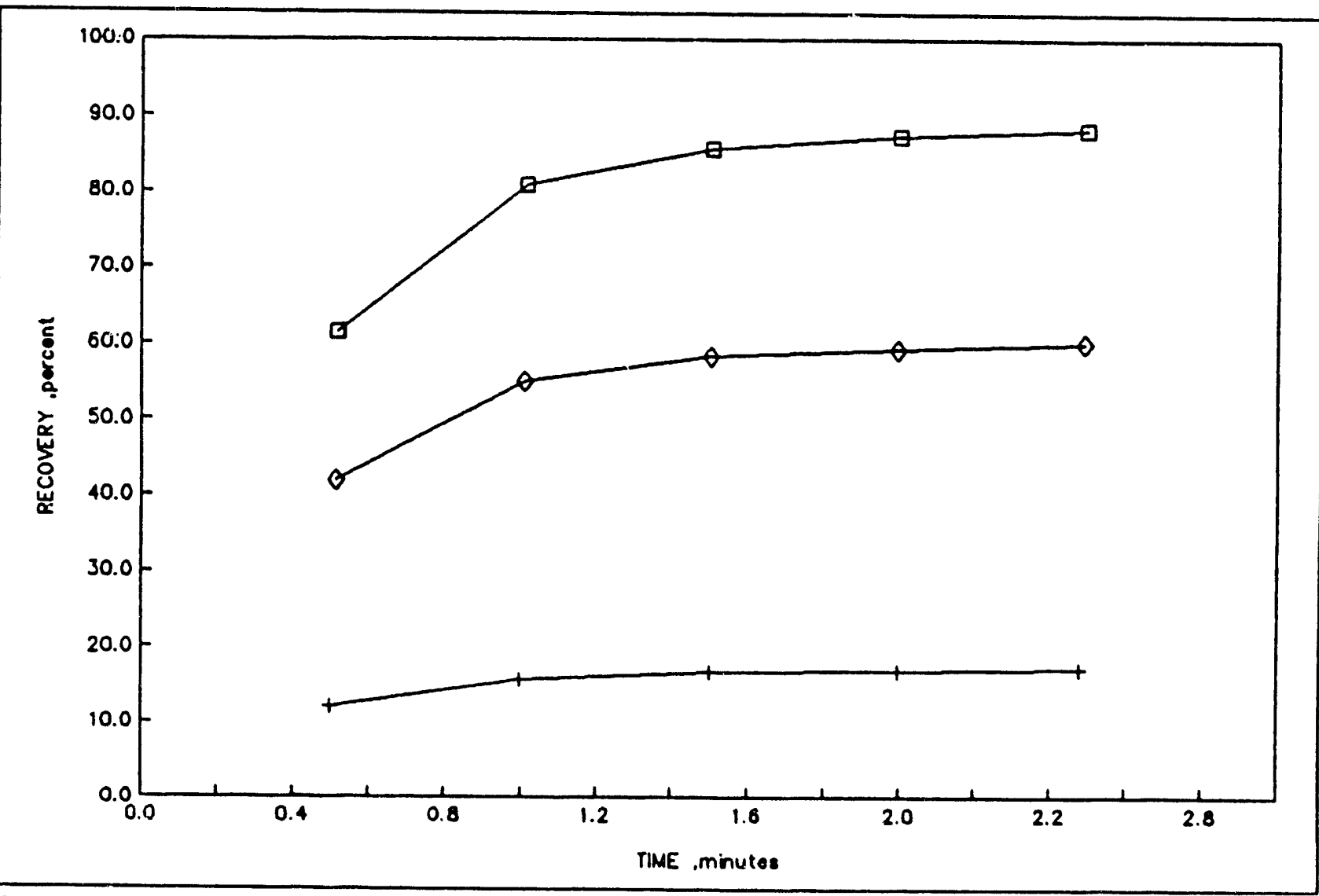

Figure A3.1. Floatation kinetic test results - Influence of floatation time on recovery. Comb.; + Ash; Suphur. 


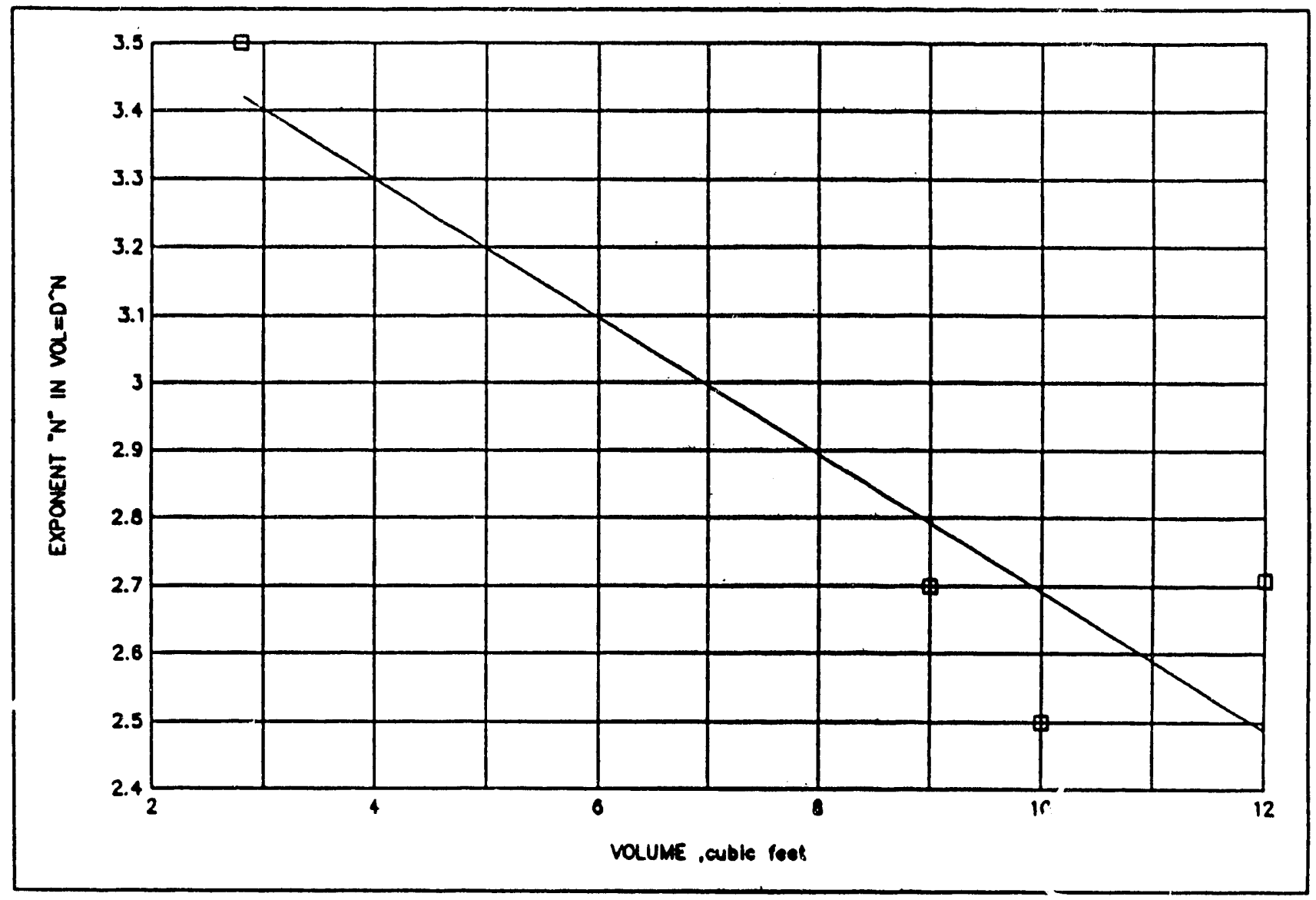

Flgure A3.2. Floatation cells geometric configuration. 


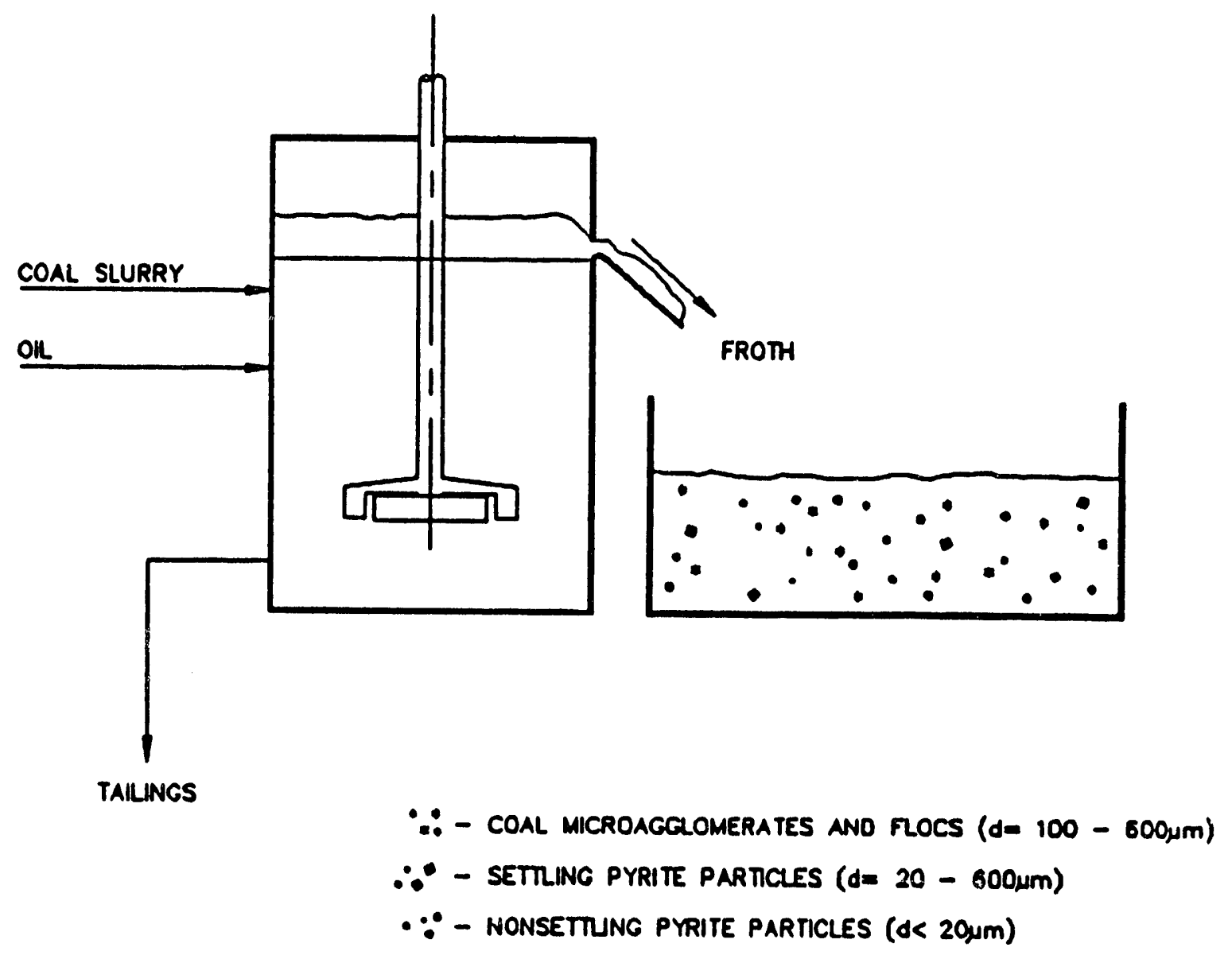

Aglolbat step for pyrite washing. 


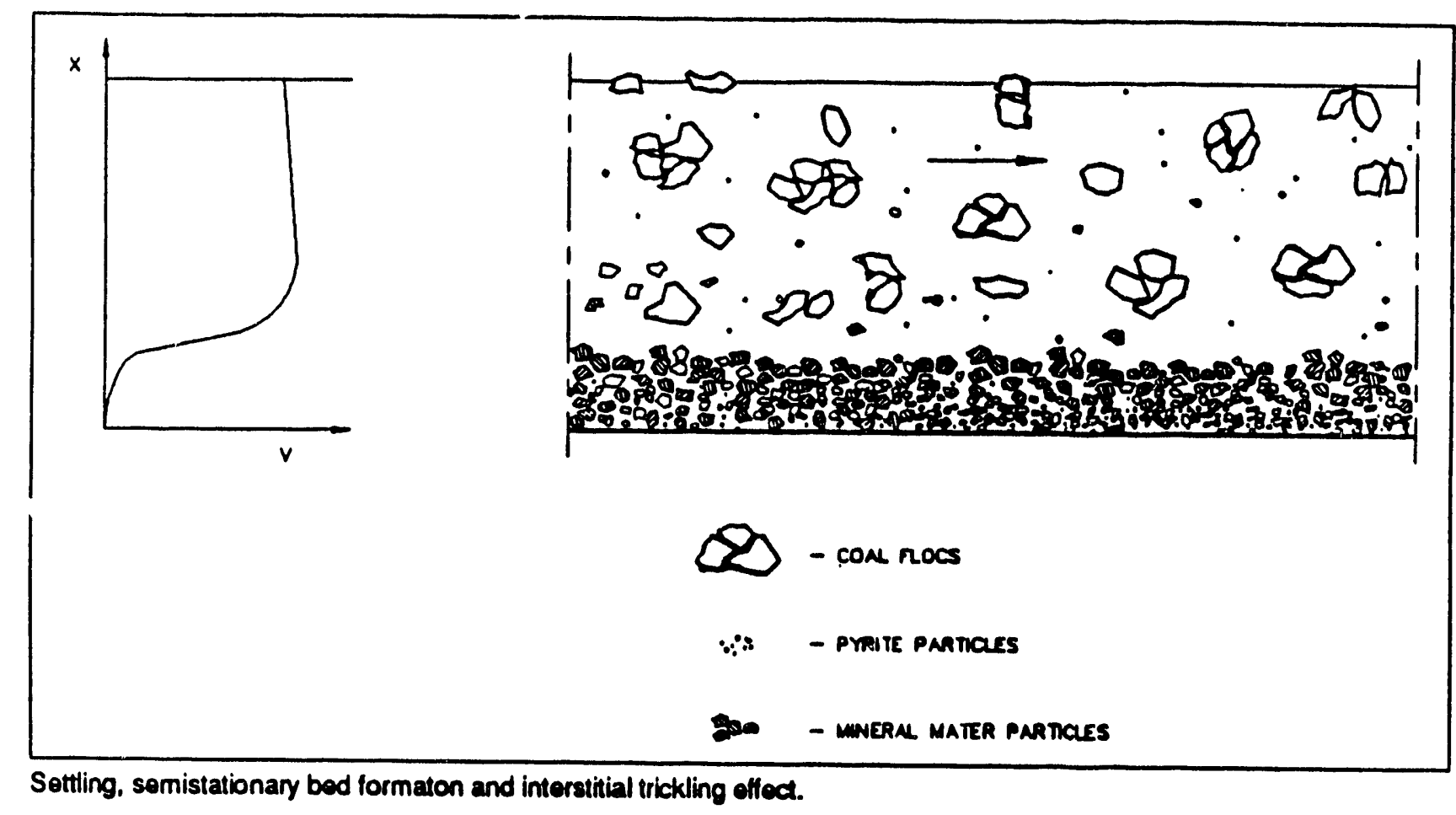

67 


\section{Appendix 4.}

\section{IATF Data for Runs 17 to 20}

\section{Sample point designation:}

$$
\begin{aligned}
& A=S-140 \text { (feed coal) } \\
& B=S-221 \text { (HSM output) } \\
& C=S-501 \text { (floatation cell froth) } \\
& D=S-401 \text { (pyrite separator) }
\end{aligned}
$$

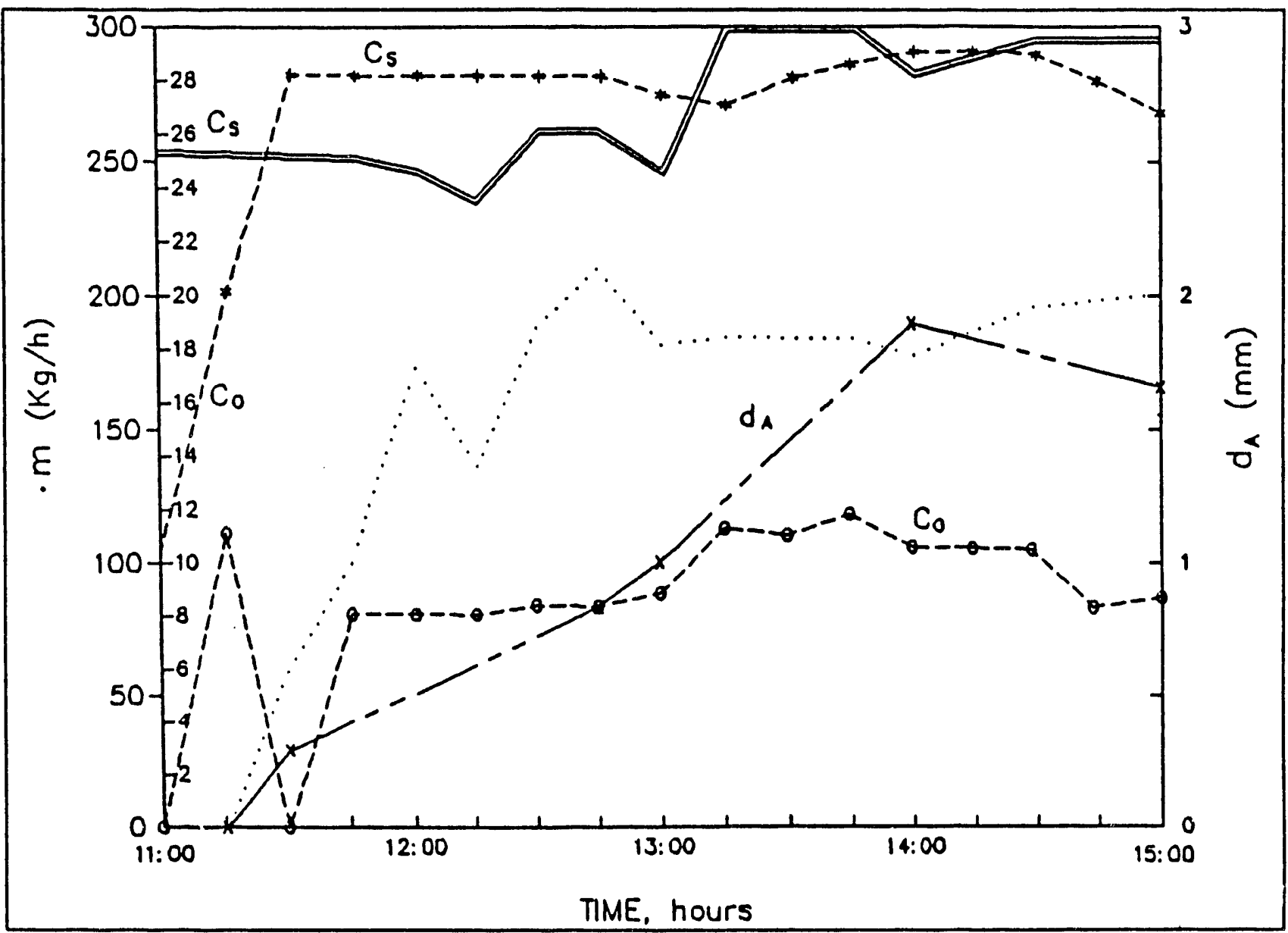

Flgure A4.1. Variation of the main process paramoters during Run 1. 


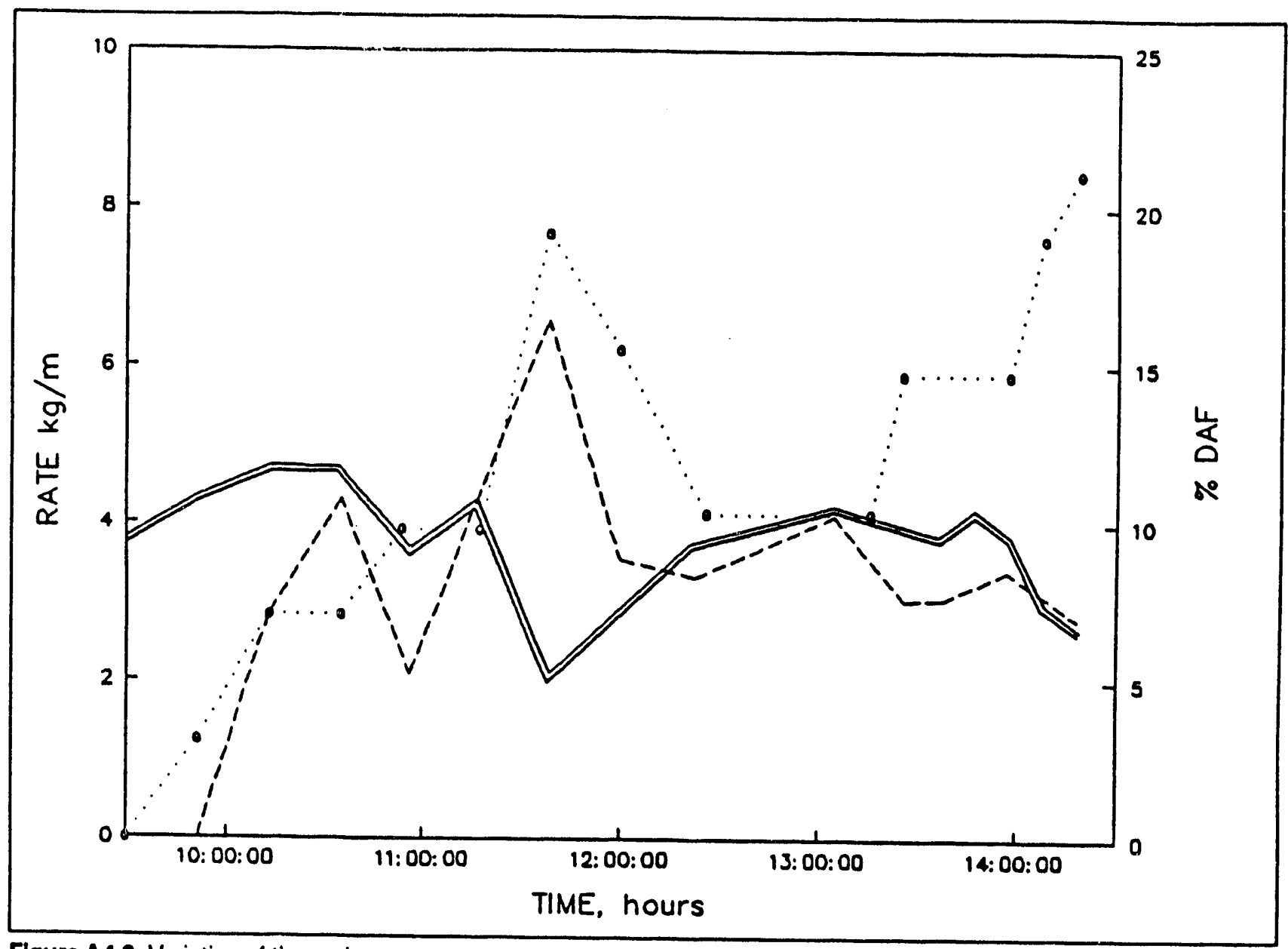

Flgure A4.2 Variation of the main process parameters during Run 5. 


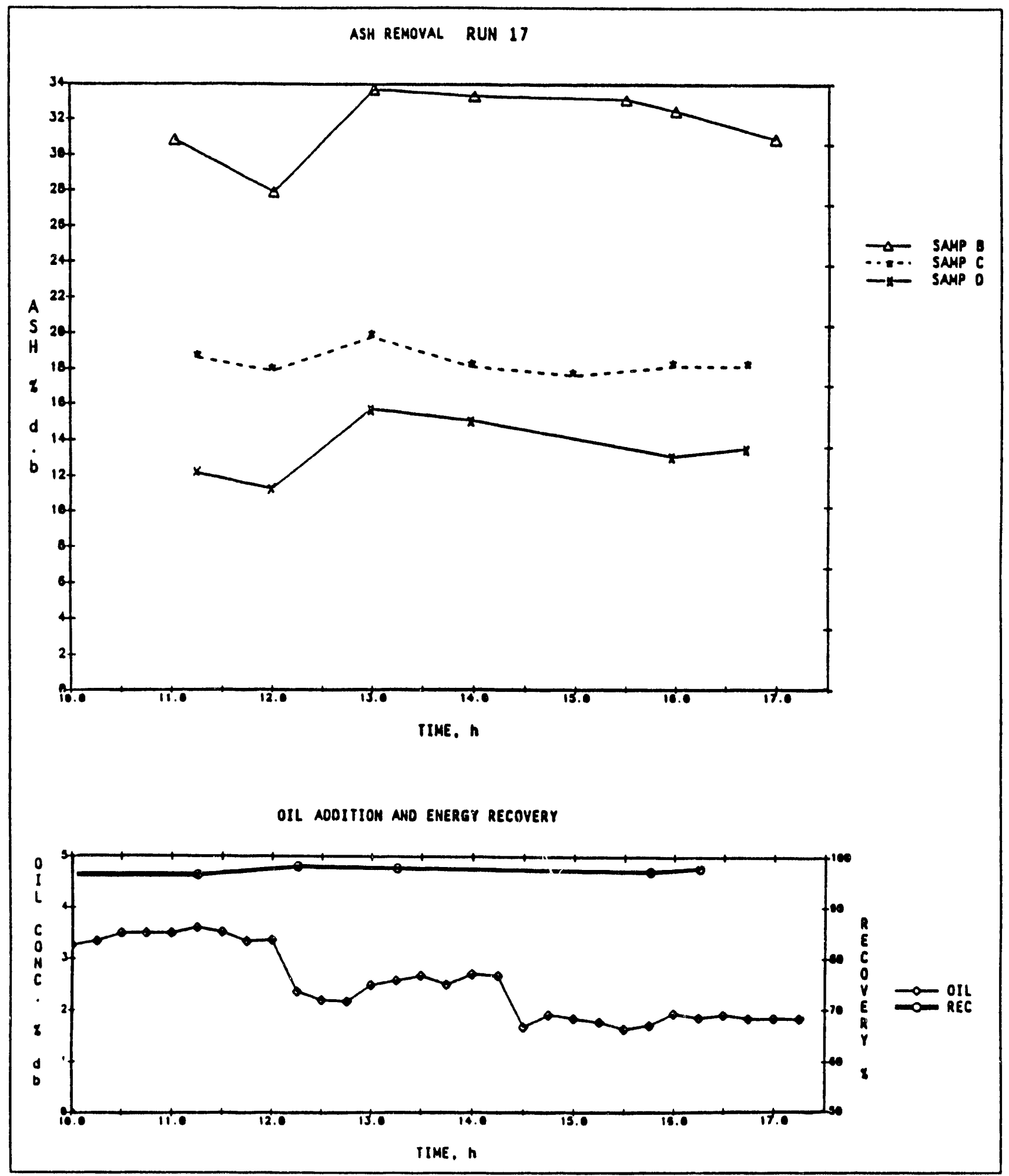




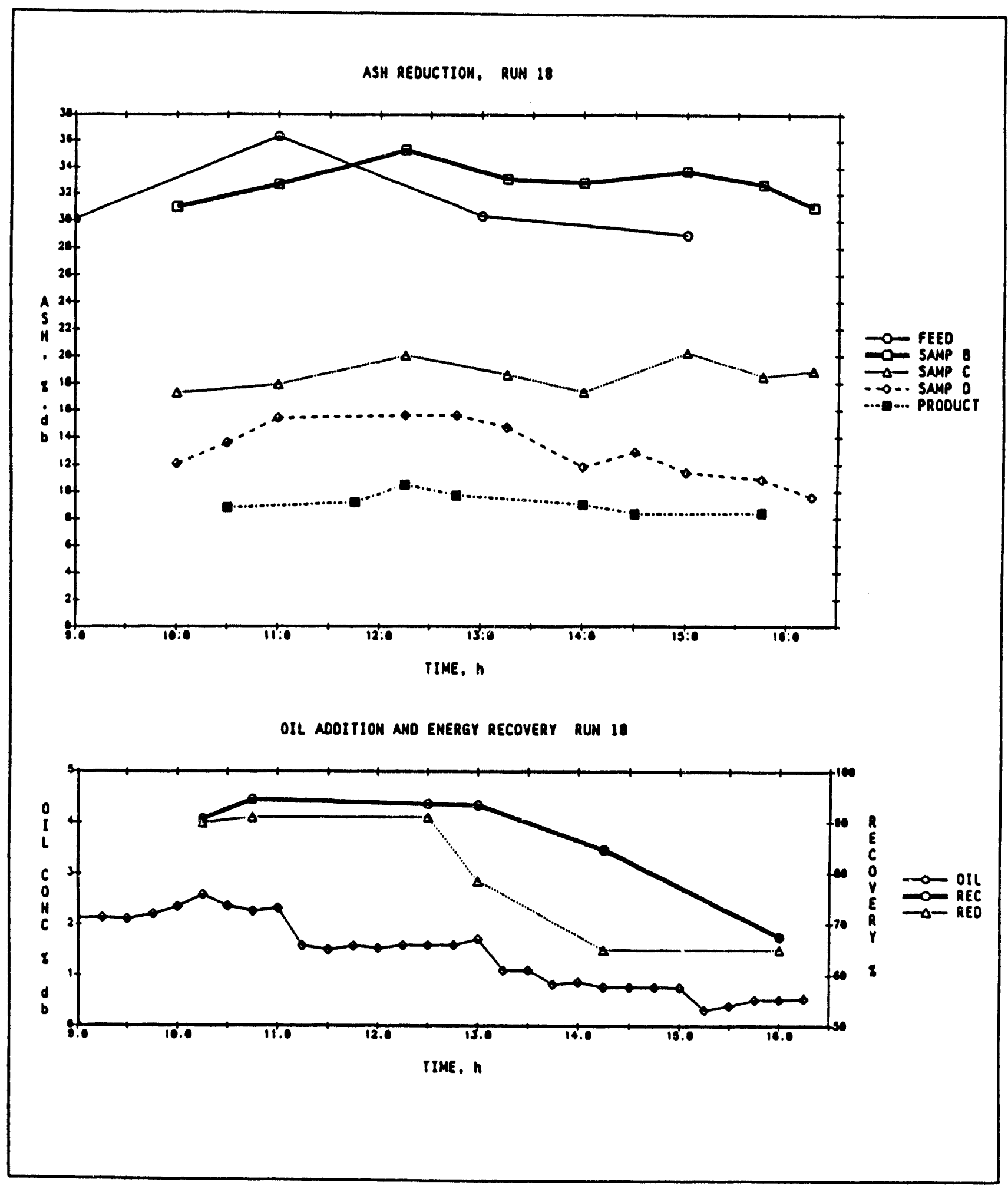


TOTAL SULFUR REOUCTION RUM 10

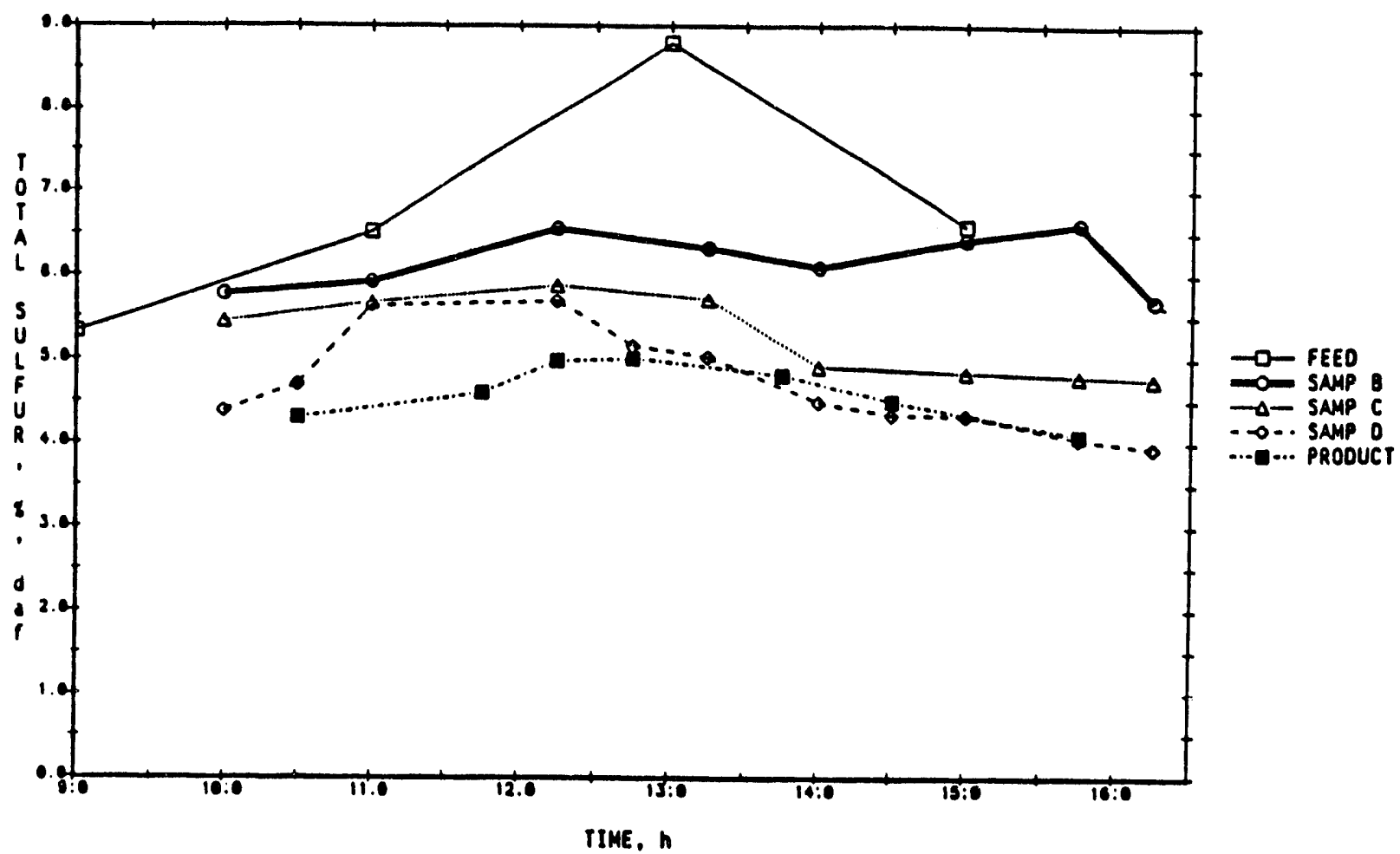

OIL AODITION AMO ENERGY RECOVERY RUN IO

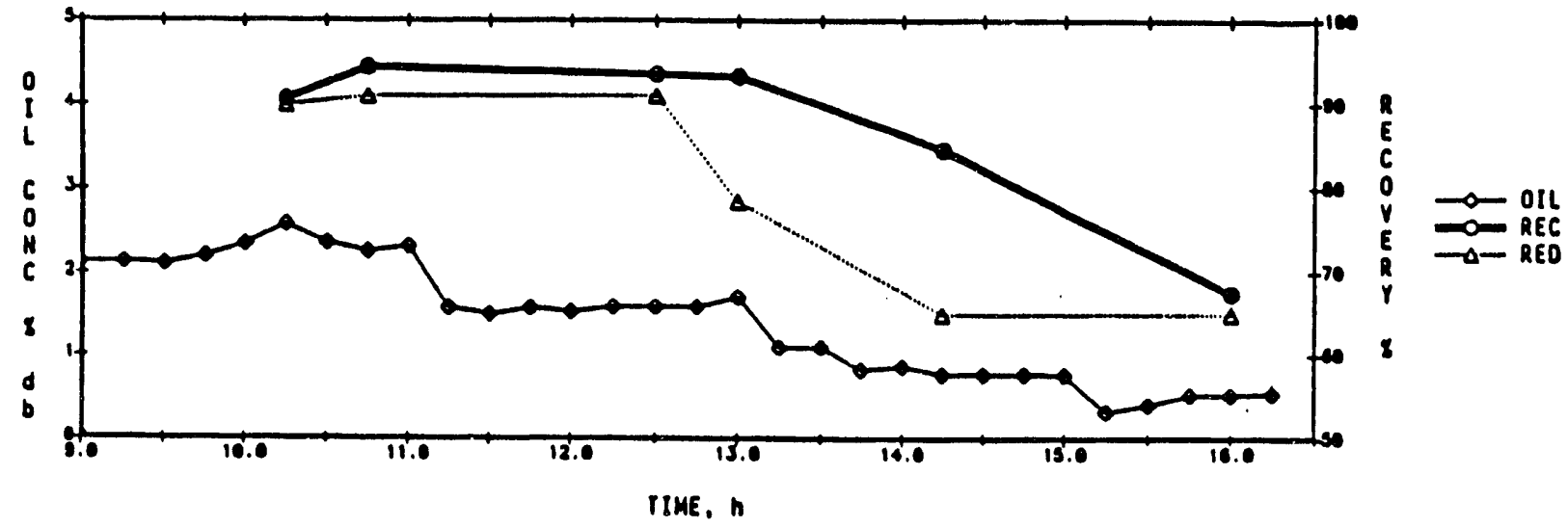




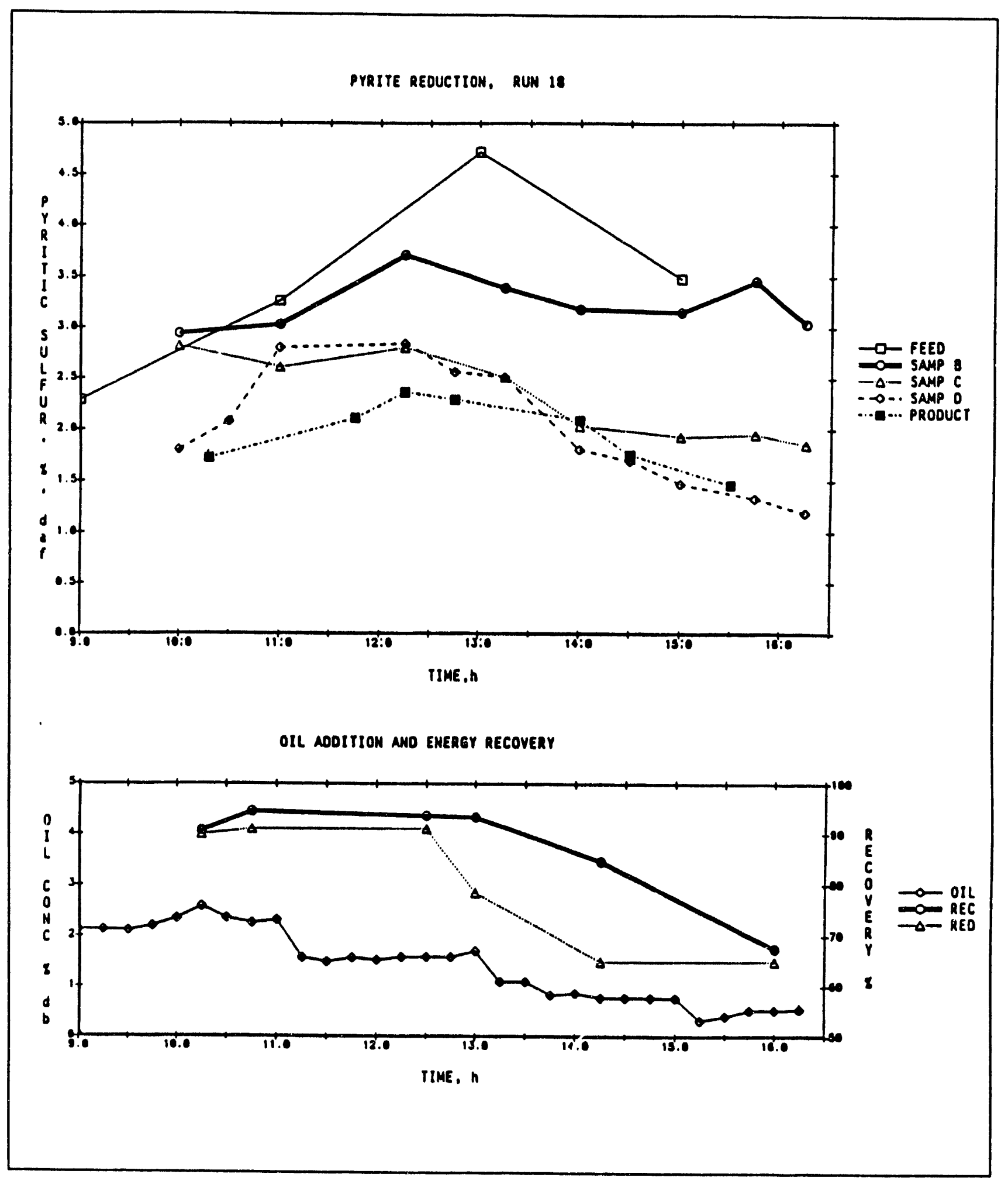




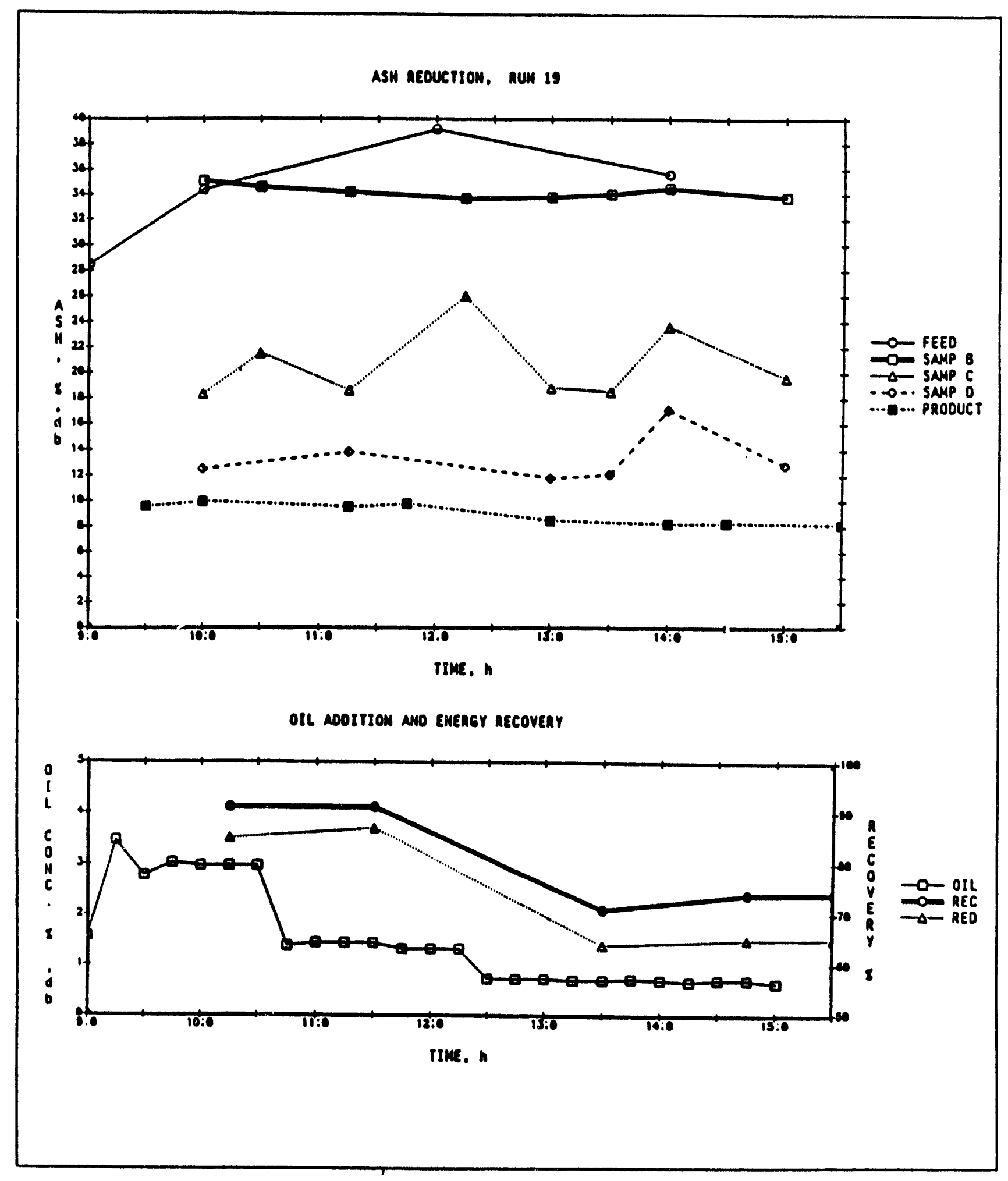


TOTAL SULFUR REOUCTION RUN is

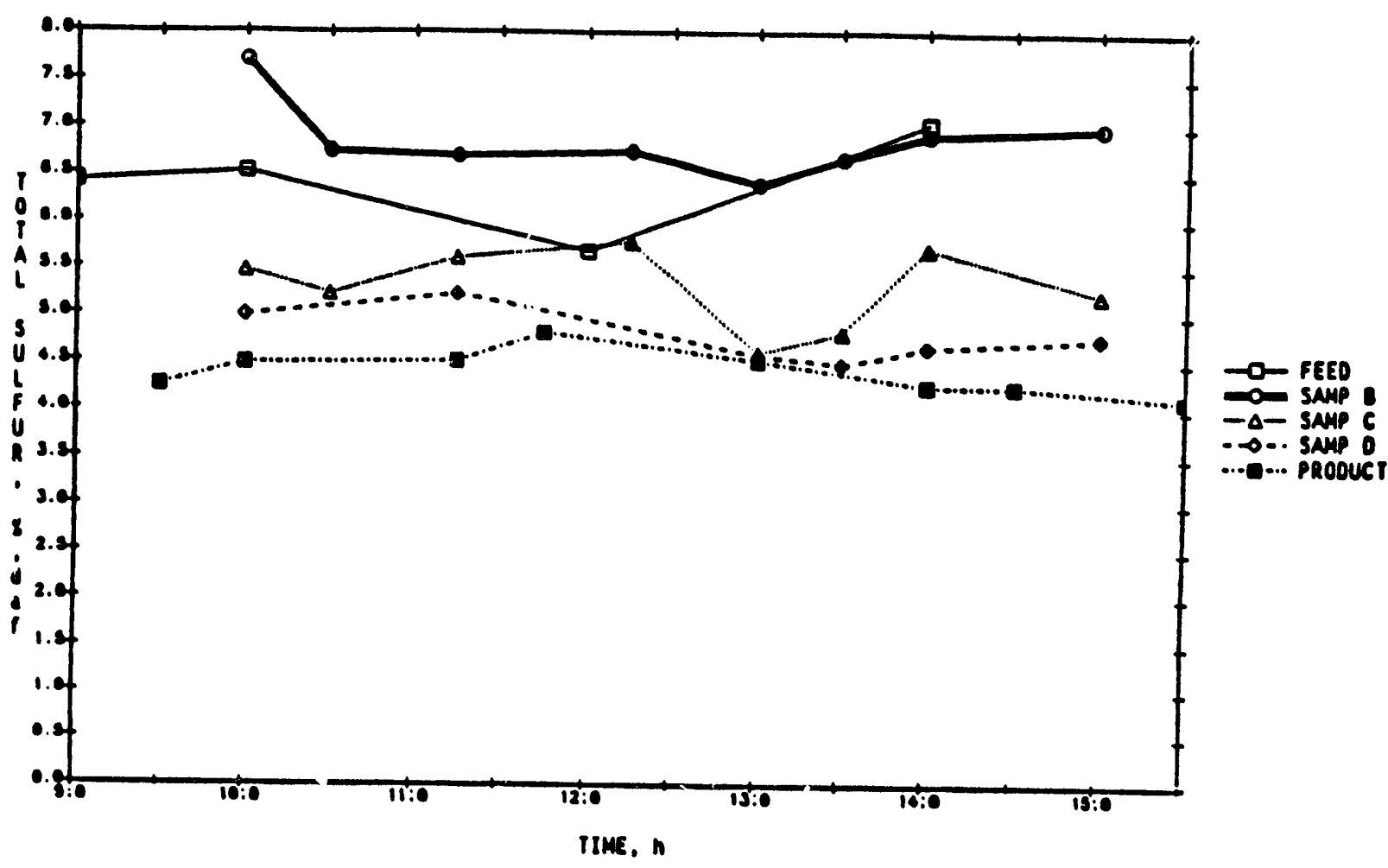

OIL ADOItION ANO EMERGY RECOVERY.

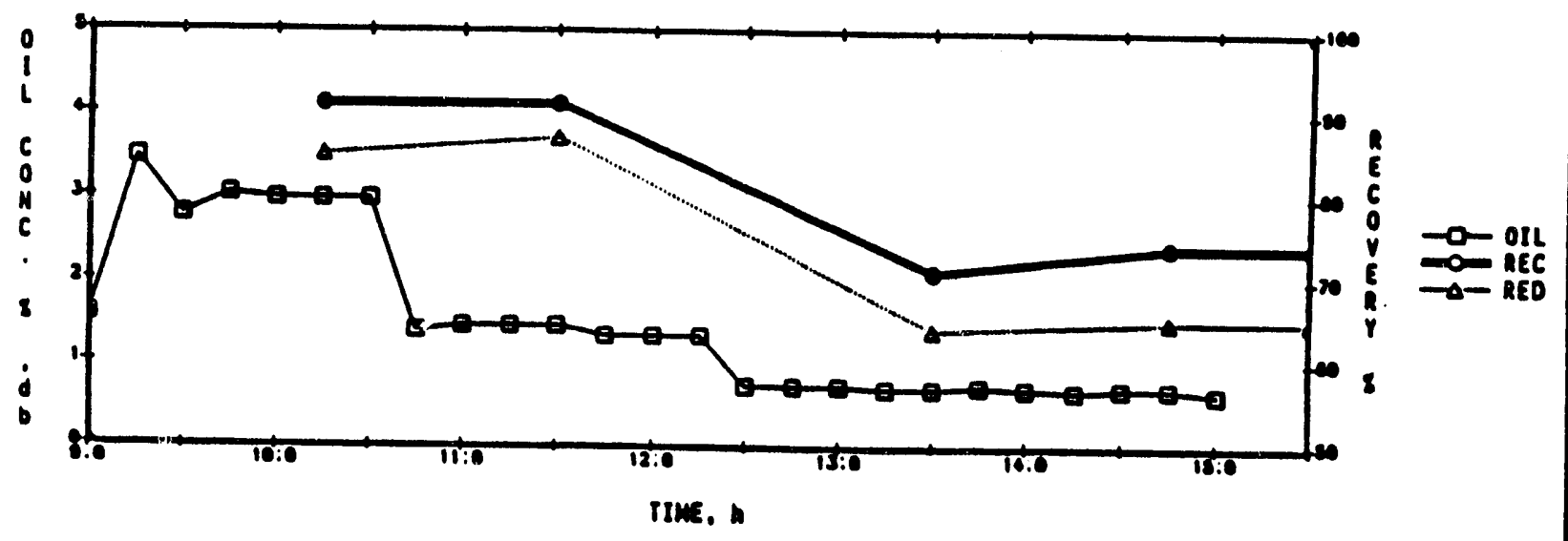




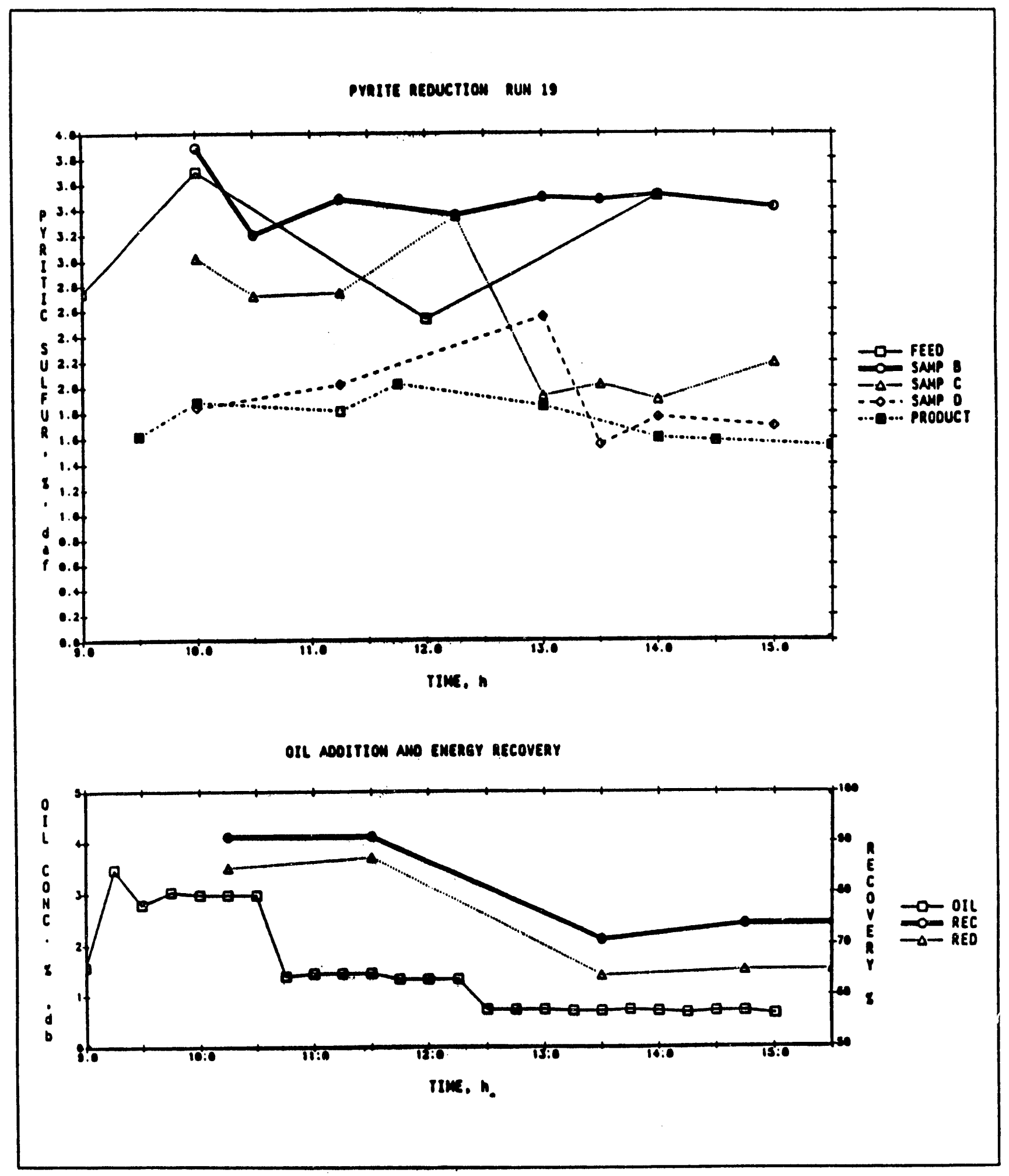


ASH REOUCTION RUN 20

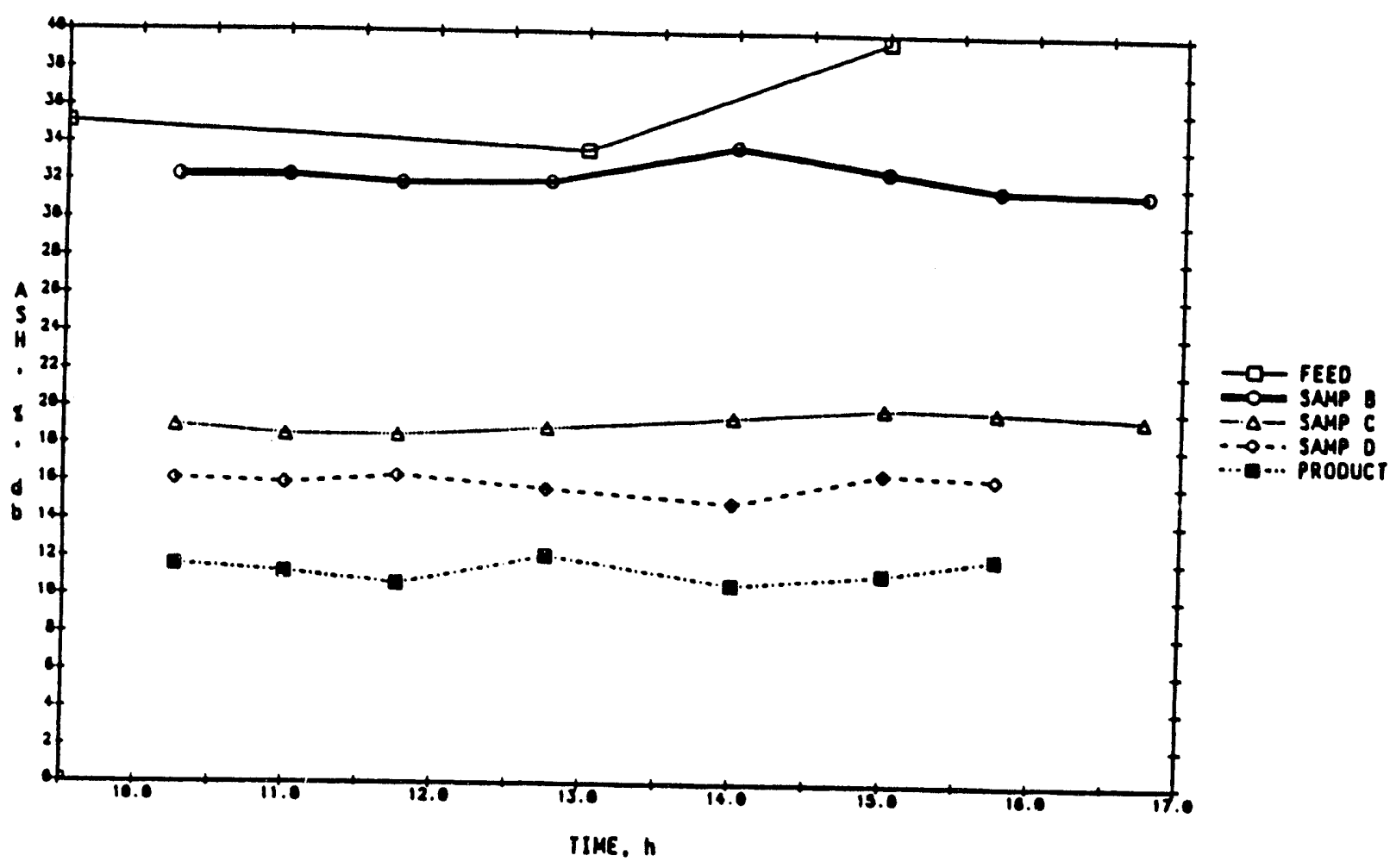

OLL hOOITION AMO EnERG ReCOVERT

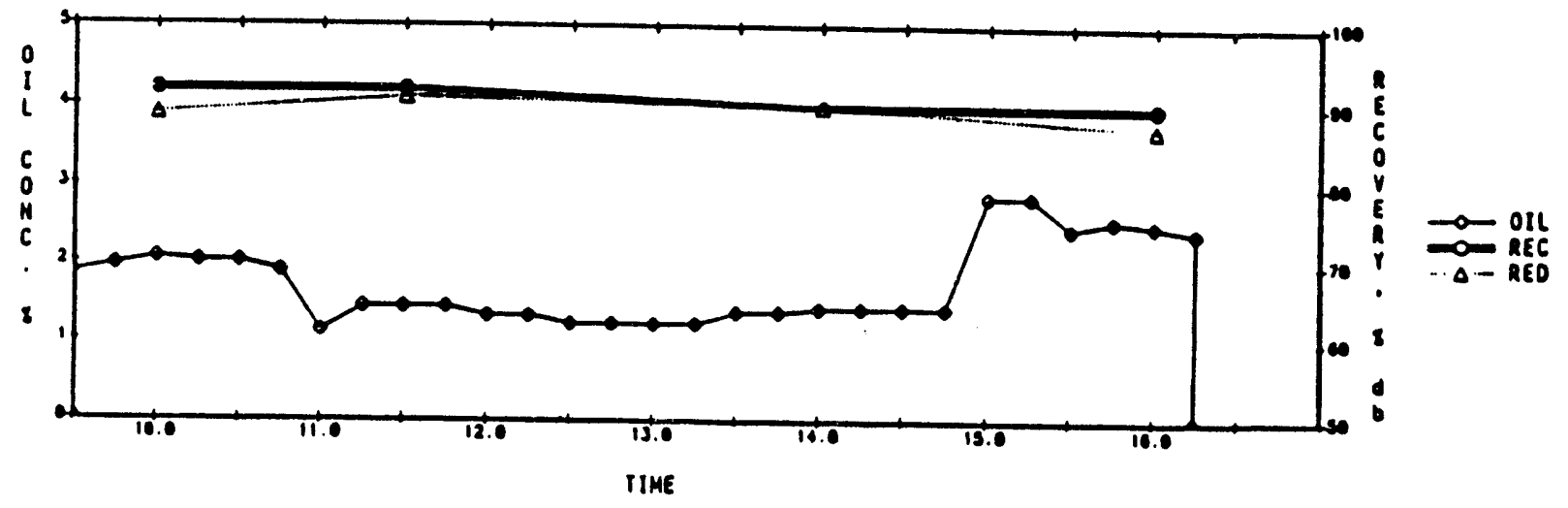


TOTAL SULFUR REDUCTION RUN 20

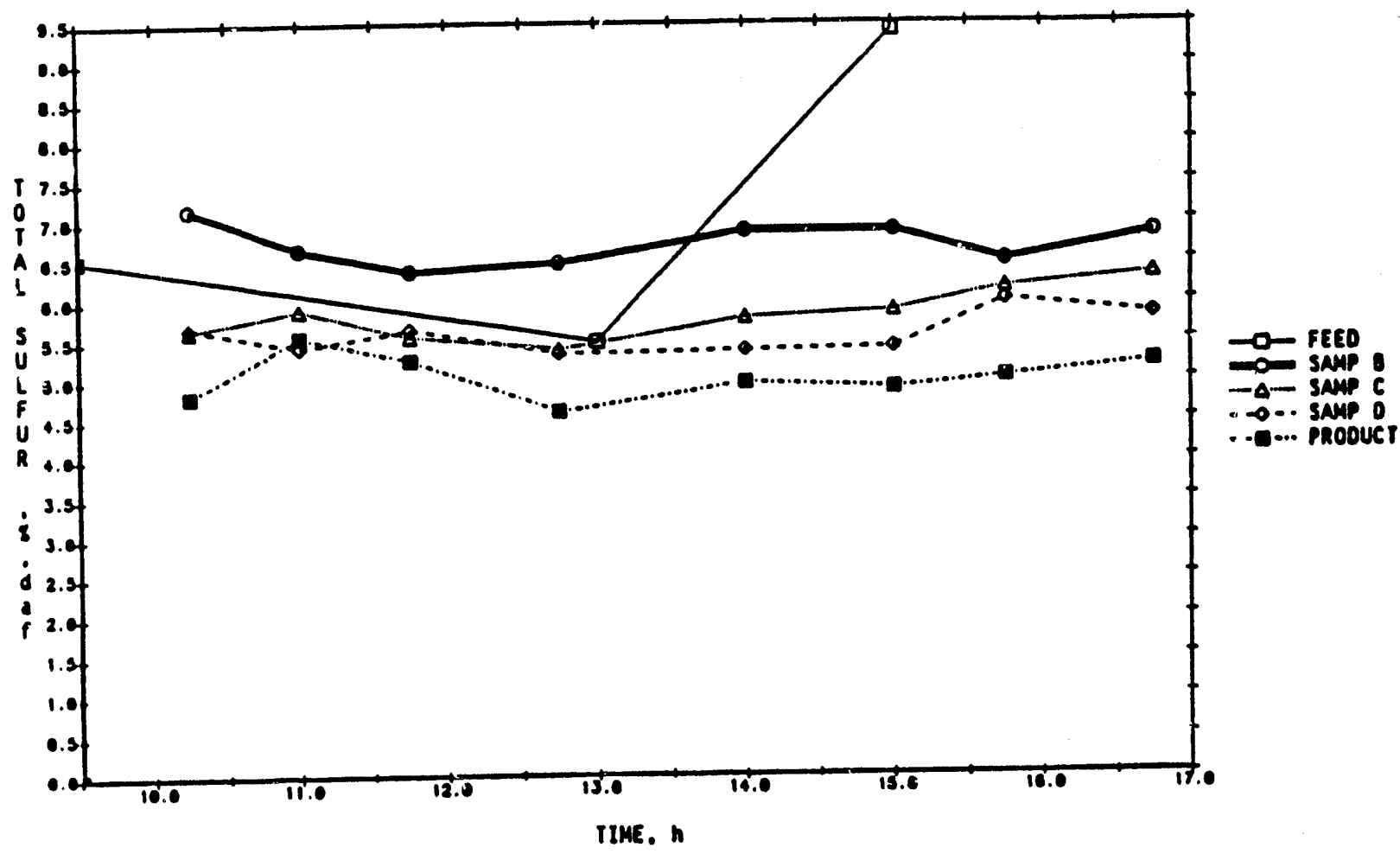

OIL ADOITION AMO EMEREY RECOVERY

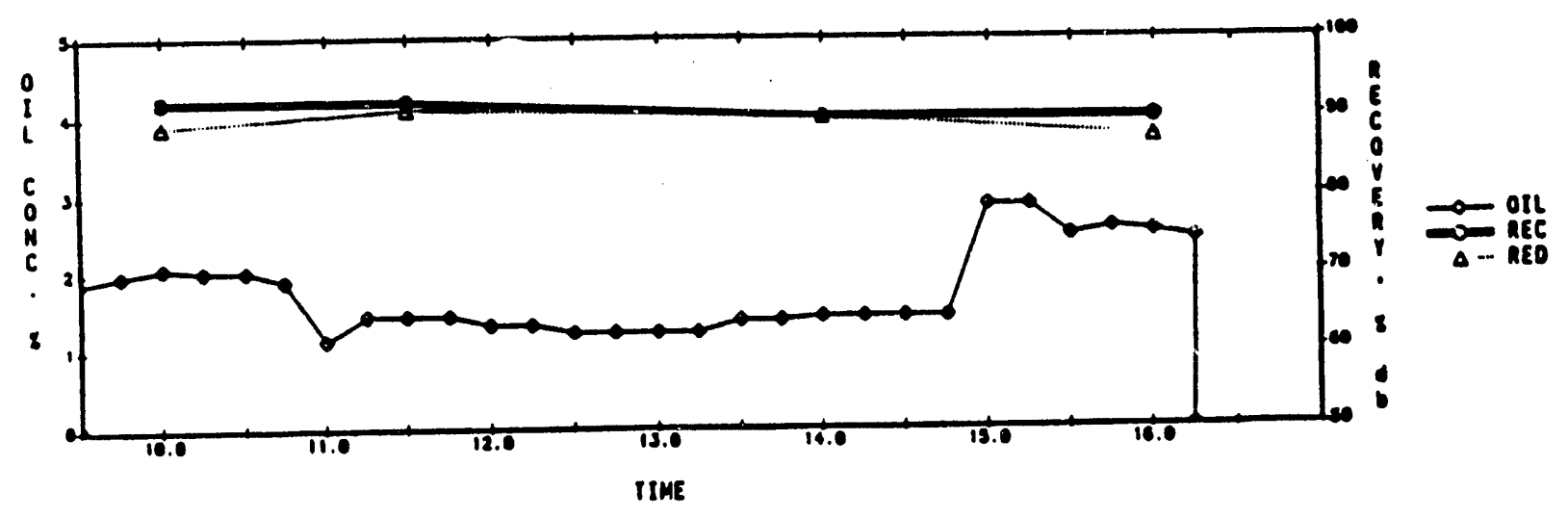


PYRITE REOUCTION RUN 20

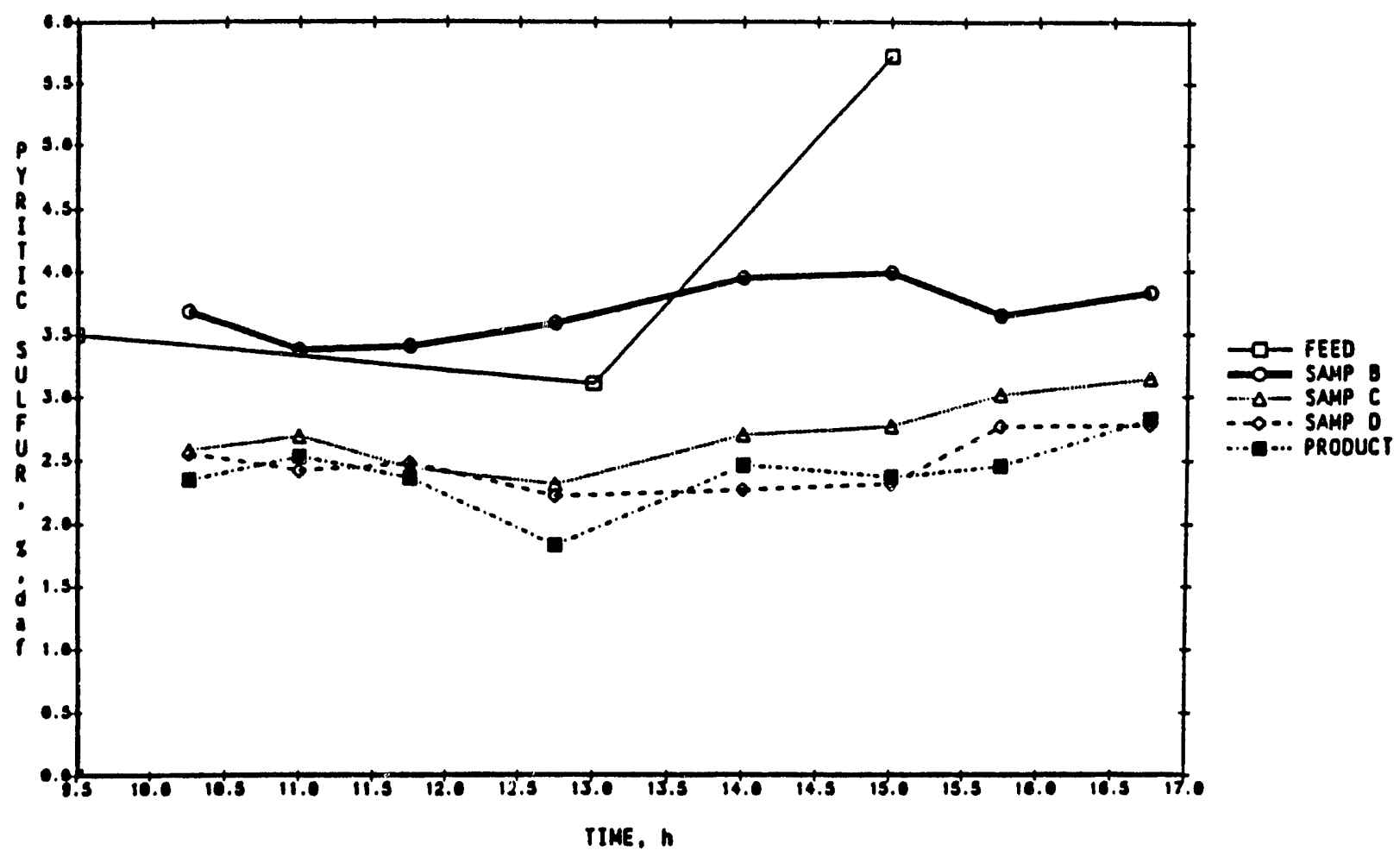

OIL AOOLTION AMO EMERGY RECOVERY

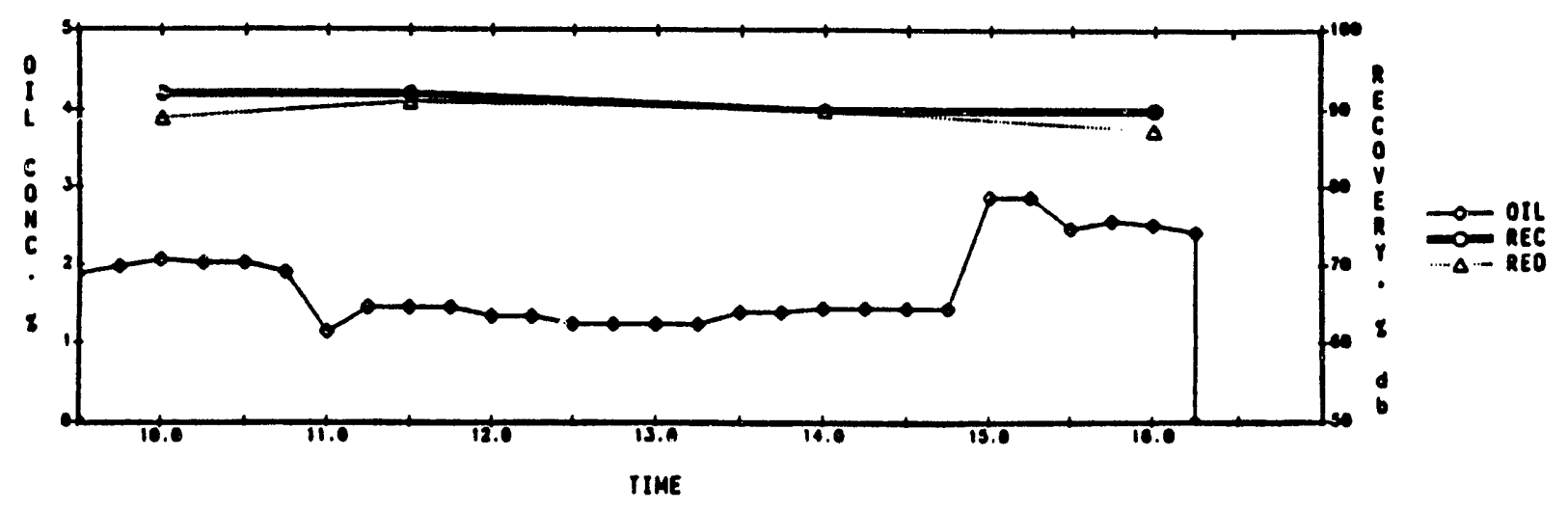




\section{Organization of Appendix 5: Volume 2}

\section{Section}

5.1. Economic Data and Factors

5.2. Plant Areas

Description

Flowsheets

Process Equipment

\subsection{Design Basis}

\subsubsection{Summary of Process Electrical Requirements}

5.3.2. Operating Cost Estimates

Plant Operation Operating Supplies

\subsection{Design Data}

\subsection{Economic Data and Factors}

Tablo A5.1. Annual operating cost factors.

\begin{tabular}{ll}
\hline Coot Element & \multicolumn{1}{c}{ Factors } \\
\hline Chemicals, & Quantities from design, unit prices \\
Fuel, Water & from Table A4, power use assumed \\
& at a rate equal to connected \\
& horsepowor.
\end{tabular}

Operating Supplina

Salaries and Wages From manpower estimates.

Payroll Burden 25 porcont of salaries and wages.

\begin{tabular}{|c|c|}
\hline \multicolumn{2}{|c|}{ Plamt Operating Labour } \\
\hline $\begin{array}{l}\text { Maintonancos } \\
\text { Labour }\end{array}$ & $\begin{array}{l}40 \text { percent of } 1 \text { to } 6 \text { percent per } \\
\text { year of Total Direct Coet. }\end{array}$ \\
\hline $\begin{array}{l}\text { Maintenance } \\
\text { Matorials }\end{array}$ & $\begin{array}{l}60 \text { percent of } 1 \text { to } 6 \text { percent por } \\
\text { yoar of Total Direct Coet. }\end{array}$ \\
\hline \multicolumn{2}{|c|}{ Plani Malntenance Cost } \\
\hline \multicolumn{2}{|c|}{ Plant Operating Direct Cost } \\
\hline $\begin{array}{l}\text { Administration and } \\
\text { Support Labour }\end{array}$ & $\begin{array}{l}15 \text { percont of direct plant oporating } \\
\text { and maintenance labour. }\end{array}$ \\
\hline $\begin{array}{l}\text { Gonoral Adminis- } \\
\text { tration Expensos }\end{array}$ & $\begin{array}{l}60 \text { percent of direct plant operating } \\
\text { and maintenance labour. }\end{array}$ \\
\hline $\begin{array}{l}\text { Property, Taxes } \\
\text { and Insurance }\end{array}$ & $\begin{array}{l}1.5 \text { percont per year of Total Plant } \\
\text { Cost. }\end{array}$ \\
\hline Plamt Operating in & Irect $\operatorname{Cos} x$ \\
\hline
\end{tabular}

Table A5.2 Factors used for estimating capital cost of different areas.

\begin{tabular}{|c|c|}
\hline Cost Elemont & Factors \\
\hline $\begin{array}{l}\text { Major Equipment } \\
\text { Cost }\end{array}$ & Vendors' quotes or provious study. \\
\hline $\begin{array}{l}\text { Installation of } \\
\text { Equipment }\end{array}$ & $\begin{array}{l}\text { Varied ( } 10 \text { to } 45 \text { porcent of major } \\
\text { equipment cost). }\end{array}$ \\
\hline $\begin{array}{l}\text { Total Proceses EqI } \\
\text { Installed Cost (PE } \\
\text { plus: } \\
\text { Piping } \\
\text { Instrumentation } \\
\text { Eloctrical } \\
\text { Buildings and } \\
\text { Structures }\end{array}$ & $\begin{array}{l}\text { Dment } \\
\text { Varied ( } 7 \text { to } 60 \text { percont of PEIC). } \\
\text { Varied (2 to } 15 \text { percent of PEIC). } \\
\text { Varied ( } 4 \text { to } 30 \text { percent of PEIC). } \\
\text { Varied (10 to } 65 \text { percent of PEIC). }\end{array}$ \\
\hline \multicolumn{2}{|c|}{$\begin{array}{l}\text { Total Orect Cost (TDC) } \\
\text { plus: } \\
\text { Engineoring, Procurement, } \\
\text { Construction } \\
\text { Management } \\
\text { (EPCM) } \quad 20 \text { percent of TDC. }\end{array}$} \\
\hline Contingencies & Varied (5 io 80 percent of TDC). \\
\hline $\begin{array}{l}\text { Total Plant Cost } \\
\text { plus: } \\
\text { Propaid Royatios }\end{array}$ & As required. \\
\hline Working Capital & $\begin{array}{l}\text { one month of operating cost and } \\
\text { one month of supplies at nominal } \\
\text { capacity. }\end{array}$ \\
\hline Total Ca & (C) \\
\hline
\end{tabular}

Tabu A5.3. Financial factors.

\begin{tabular}{|c|c|}
\hline Cost indicas and Cost Data: & 1980 U.S. Dollare \\
\hline Financial Criteria & $\begin{array}{l}\text { - } 100 \text { percent equity for ROR } \\
\text { calculation } \\
\text { - prices f.o.b. plant site } \\
\text { - taxation } \\
\text { - full capacity and operation in } \\
\text { Year } 1 \\
\text { - depreciation straight line over } \\
10 \text { years } \\
\text { - plant life } 25 \text { years }\end{array}$ \\
\hline $\begin{array}{l}\text { Total Plant Cost } \\
\text { Allocation }\end{array}$ & $\begin{array}{l}\text { Year } 1.20 \text { percont } \\
\text { Year } 2.50 \text { percomt } \\
\text { Year } 3.30 \text { percent }\end{array}$ \\
\hline
\end{tabular}


Table A5.4. Pricos and rates for chemicals, fuels, utilities, otc.

\begin{tabular}{ll}
\hline Feed Coal & $\$ 27.00 /$ ton \\
Feed Oil (Maya) & $\$ 102.60 /$ ton \\
Feed Diesel & $\$ 178.40 /$ ton \\
Electricity & $\$ 0.065 / \mathrm{kwh}$ \\
Fuel & $\$ 2.90 / 10^{6}$ Btu coal \\
Water & $\$ 0.60 / 1000$ U.S. gallons \\
Chemical & \\
$\quad$ Floculants & $\$ 1.60 /$ lb \\
Refuse Disposal & $\$ 7.00 /$ ton \\
\hline
\end{tabular}

Table A5.5. Contingency factors.

\begin{tabular}{ll}
\hline New concepts with limited data & $80 \%$ \\
Concept with bench-scalo data available & $60 \%$ \\
Small pilot-plant data & $35 \%$ \\
Full-size demonstration plant & $20 \%$ \\
Commercial process & $10 \%$ \\
\hline
\end{tabular}

\begin{tabular}{llc}
\hline Area & \multicolumn{1}{c}{ Descriptlon } & Factor Used \\
\hline 100 & Cosal Delivery, Storage and Crushing & 10 \\
200 & Coal and Oil Preparation & 10 \\
300 & Agglomeration and Floatation & 35 \\
400 & Agglomeration and Separation & 35 \\
500 & Water Treatment & 20 \\
600 & Product Loadout & 10 \\
700 & Offsites & - \\
\hline
\end{tabular}

\subsection{Plant Areas}

$\begin{array}{cl}\text { Area No. Area Designation } \\ 100 & \text { Coal Delivery, Storage and Crushing } \\ 200 & \text { Coal and Oil Preparation } \\ 300 & \text { Agglomeration and Floatation } \\ 400 & \text { Agglomeration and Separation } \\ 500 & \text { Water Treatment } \\ 600 & \text { Product Loadout } \\ 700 & \text { Offsites }\end{array}$

\subsubsection{Coal Dellvery, Storage and Crushing:} Area 100 -Reference Flowsheet \$ ARCA7

\section{Design Considerations}

ROM coal would be delivered from the mine to the plant in trucks owned by the coal company. No provision was made for spare or duplicate equipment for back-up in case of equipment failures.

The selection and sizing of equipment for the area was based on the following design considerations:

- Trucks will deliver coal to the plant on a 12 hday $x$ 5 days/week basis.

- The crushing circuit is to provide 390 tph of $-50 \mathrm{~mm} \times 0$ raw coal for the Coal and Oil Preparation Area on a 24 hday $\times 7$ days/week basis.

- The production of fines through the crushing circuit is to be minimized.

\section{Process Description:}

ROM Coal is dumped by trucks through a grizzly into a 400 t capacity dump hopper. An apron foeder is then used to deliver the coal from the dump hopper to the coal breaker at a rate of $1500 \mathrm{th}$. The coal breaker reduces the coal to $150 \mathrm{~mm} \times 0$ and the $\infty$ al is then taken by belt conveyor to a transfer house. Belt scales have been included to monitior the quantity of the coal deliveries. Rocks are removed from the breaker and stockpiled at the rate of $10 \mathrm{tph}$. From the transfer house the coal can be directed either to the outside storage area or to the 500 tonnes raw coal storage bin in the plant crushing area. The conveyor system which goes from the dump pit area to the transfer house and to the plant crushing area will be enclosed in insulated and heated galleries.

Coal that is transferred to the outside storage area becomes part of a 3-day live storage pile or 10-day compacted storage pile. Reclamation from the piles is done with a front-end loader and the coal is introduced back into the system through the 400 t dump hopper.

Inside the crushing plant, coal will be fed from the $500 \mathrm{t}$ raw coal bin via a vibrating ieeder at a rate of 390 tph to the secondary crusher circuik. The $150 \mathrm{~mm} \times 0$ material will be screened at $-50 \mathrm{~mm}$, the oversize crushed in a double roll crusher to $-50 \mathrm{~mm}$, and the product added back to the screen undertlow. The $-50 \mathrm{~mm}$ product will then be transferred via belt conveyor to the Coal and Oil Preparation Area. Atlowance has been made for dust collection at various points in the system. 


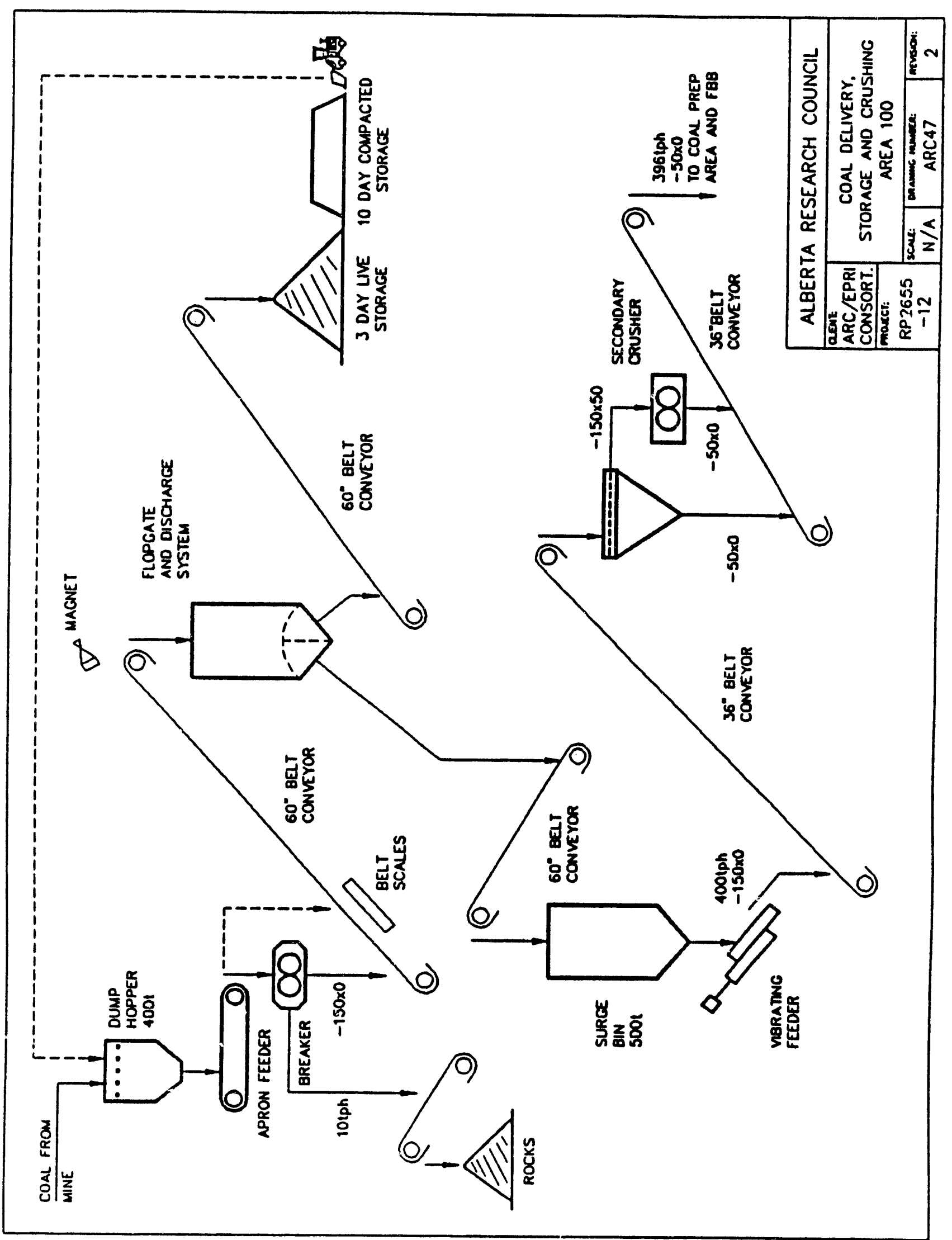




\section{ESTIMATE BUMARY}

CLIENT: ARC/EPRI CONSORTIUM

PROJECT NO.: RP2655-12

AREA DESIGNATION: Coal Delivery, Storage and Crushing: Area 100

DATE OF I880E:

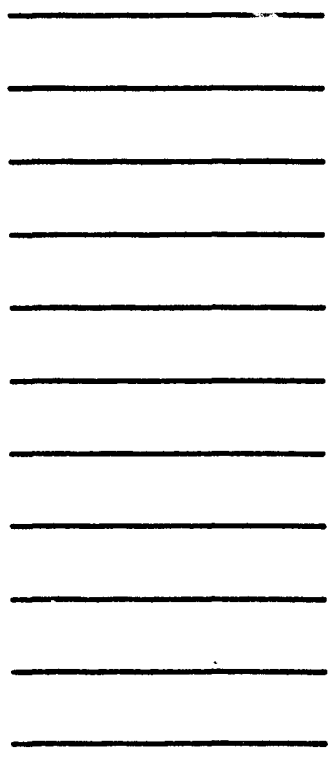

TOTAL PROCE8B EQUIPHENT

INSTALLED COBT (PEIC)

ALLOWANCE FOR:

Piping

Instrumentation

Electrical

Bldg./structural

TOTAL DIRECT COBT

IMBTALEED COST

$\$$

$\$$

TYPE OF ESTIMATE: $₫ 30$ \&

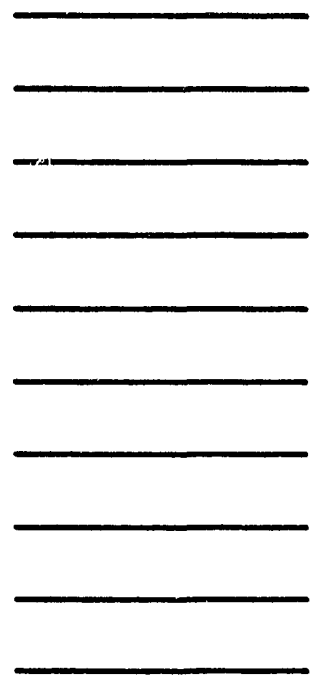

$\$ \quad 3,628,000$

$1,640,000$

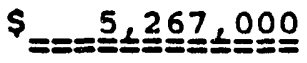


CLIENT: ARC/EPRI CONSORTIUM

PROJECT NO.: RP2655-12
BREET NO.: 1 OR 2

I8SOE DATE:

AREA DESIGNATION: Coal Delivery, storage and Crushing: Area 100

ITEM NO, QUNNTITY

1

2

3

4

5

6

7

8

9

10

11

12
1

1

1

1

1

1

1

1

1

1

1

1

\section{DESCRIPIION}

400 t Capacity Dump Hopper $c / w$ grizzly

Apron Feeder, 1500 tph capacity, $20 \mathrm{hp}$ motor, dribble chute

Rotary Breaker, 1500 tph capacity, +4" fued, 3" $x 0$ product, $100 \mathrm{hp,}$ $100 \mathrm{hp}$ motor, discharge chute

Belt scales

Magnet (cost included in \#4)

Flop-Gate and Discharge Chutes

500 t Capacity Surge Bin

Vibrating Feeder, 450 tph, 25 hp motor, discharge chute

Front End Loader

Vibrating Screen, $450 \mathrm{tph}, 50 \mathrm{~mm}$ aperture, $6^{\circ} \times 16^{\circ}$, single deck, 10 hp motor, discharge chute

Raw Coal Roll Crusher, 450 tph capacity, double roll 34" $\times 36$ ", $2 \times 75$ hp motors, discharge chute

Flop-Gate and Discharge Chutes (cost included in 15)

\section{PRICE}

$\$ \quad 773,000$

83,000

196,000

41,000

76,000

69,000

43,000

534,000

29,000

155,000 


\section{EOOTPYENT LI8T}

CLIENT: ARC/EPRI CONSORTIUM

PROJECT NO.: RP2655-12

BEgET NO.: 2 OP 2

I880E DATB :

AREA DEsIGNatrox, Coal Delivery, Storage and Crushing: Area 100

ITEY NO, OONATTEY

DEFCRIPTION

PRTCE

13

Dust Collection System, total motor $\$ \quad 88,000$ hp $=140$

14

Dump Pit Sump Pump and Storage Area

Sump Pump, total motor hp $=10$

193,000

15

Belt Conveyors: Allowance for $700 \mathrm{ft}$ of 60" belts, 300 ft of $36^{\prime \prime}$ belts,

total motor hp $=350$

TOTAL EQUIPMENT COST

$\$ 2,883,000$

INSTALIATION AT $26 \%$ OF EQUIPMENT COST

$\$$

745,000

TOTAL INSTALLED EQUIPMENT COST

FOR AREA

$\$ 3,628,000$ 


\subsubsection{Coal and OII Preparation:}

\section{Area 200-Reference Flowsheet * ARC48}

\section{Design Considerations}

The purpose of the Coal and Oil Preparation Area is to prepare and condition coal water stumy including addition of additives, and to receive and mix bridging oil components (crude oil and diesel) to be used in the Agglomeration and Floatation Area.

The following design guidelines were developed:

- The area is to process 300 tph of $-50 \mathrm{~mm} \times 0$ raw coal on a 24 Wday $\times 7$ dayshweek basis.

- Raw $-50 \mathrm{~mm} \times 0$ coal is to be pulverized to 50 percent minus 100 mask or $d_{50}=150 \mathrm{Mm}$.

- A residence time of 5 minutes is to be allowed for coal conditioning (wetting) in the shumy mixing tanks.

- The crude oil and diesel delivery tanks are to provide five and thirty days delivery storage, respectively.

- The crude oil tank is to be insulated and equipped with steam heating coils to keep the oil temperature (viscosity) at above $20^{\circ} \mathrm{C}$ (14.5 API).

- All piping for crude oil and bridging oil is to be insulated and steam heated so that it is possible to pump the oil in cold weather.

- Oil tanks are bcated in a bermed area to contain any spills.

Process Description

390 tph of $-50 \mathrm{~mm} \times 0$ coal from the Coal Delivery. Storage and Crushing Area is transferred by con- veyor to four ball mills, operating in parallel, where it is pulverized to $-0.6 \mathrm{~mm} \times 0$. The coal is then discharged to two slumy mixing tanks where 910 tph recycle water is added to prepare a 29.4 percent coal stury, dry w/w basis. The coal slumy is conditioned in the mixing tanks by adding appropriate additives and mixing for 5 minutes (mean residence time). Each tank is equipped with an agitator and a slumy pump to move the slumy to the Agglomeration and Floatation Area.

The Coal and Oil Preparation Area also serves to receive crude oil and diesel, and to blend the oil intu bridging oil formulation. The crude oil is delivered to a 50,000 bbl, 5-day storage tank. The tank is steam heated and mixed using a recirculation loop on the crude oil pump. The diesel is delivered to a 300 ton, 30-day storage tank from where it is pumped to the bridging oil tank.

1.6 tph of crude oil and 0.4 tph of light oil are mixed in the bridging oil tank by recirculation of the blended oil. The bridging oil tank, like the crude oil tank, is insulated and steam heated to keep the oil viscosity 'API 15. The crude and bridging oil pipes are steam traced to keep the oil pumpable in cold weather.

The blended bridging oil is transferred to the $\mathrm{Ag}$ glomeration and Floatation Area via the B.O. pump at the rate of $2.0 \mathrm{tph}$. 


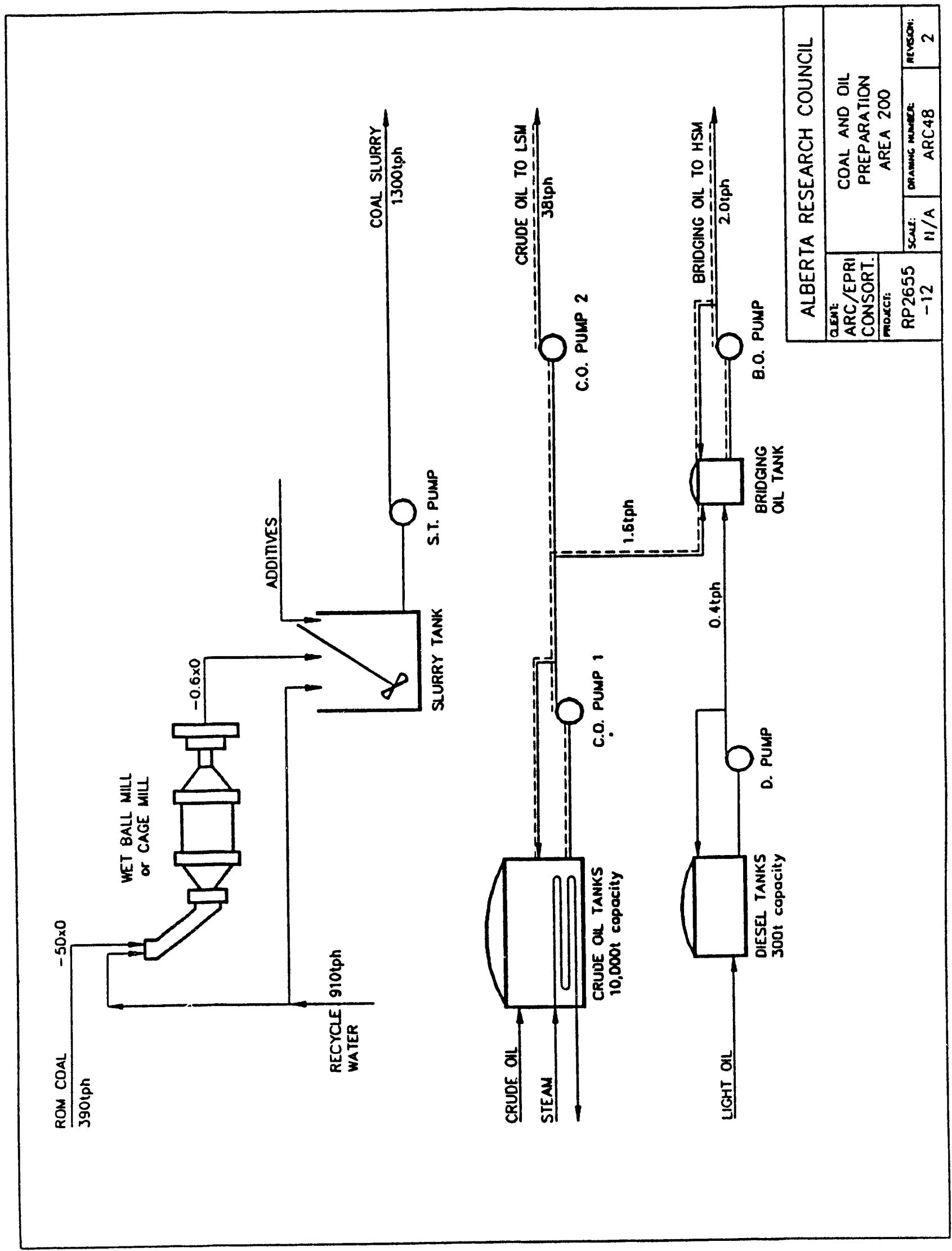




\section{RROCES8 EOOTPYFIT}

\section{EBTTMATE GOTOYAXY}

CLIENT: ARC/EPRI CONSORTIUM

PROJECT NO.8 RP2655-12

AREA DESIGNATION: Coal and O1l Preparation: Area 200

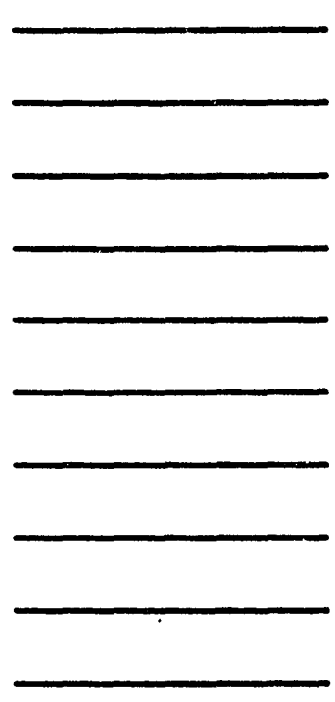

TOTAL PROCE88 EQTIPHENT

INBTALLED COBT (PEIC)

ALLOWANCE FOR:

Plping

Instrumentation

Electrical

Bldg./Structural

TOTAL DIRECT COST

\section{INBThLIFD COST}

$\$$

\$

$8,527,000$

$\$$

$$
4,215,000
$$

TYPE OF E8TIKATE: \pm 308

DATE OF I880E:
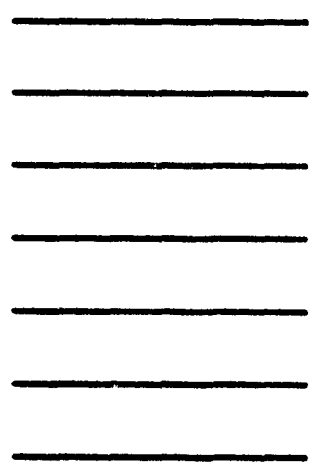

$\$$

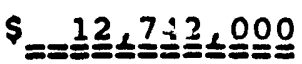


EOOIPKENT LI8T

CLIENT: ARC/EPRI CONSORTIUM

PROJECT NO.: RP2655-12
BHEET NO.: 1 OF 1

IS80E DATE:

AREA DESIGNATION: Coal and Oil Preparation: Area 200

ITEY NO, OOANTITY

1

2

3

4

5

6

7

8

9

10

11

\section{DESCRIPTION}

Wet Ball Mills, 100 tph capacity each, $4 \times 2500 \mathrm{hp}$

Slurry Mix Tanks, $15^{\prime} \phi \times 10^{\prime}$ SS

Agitators, $2 \times 100 \mathrm{hp}$ motor

Slurry Pumps, 2500 USGPM,

$2 \times 50 \mathrm{hp}$, one spare

Crude oil Tank, 50,000 bbl, insulated, with steam heating coils

Crude oil Pump, $1 \& 2,400$ USGPM, $20 \mathrm{hP}$

Diesel Tank, 3,000 bbl

Diesel Pump, 20 USGPM, $5 \mathrm{hp}$

Bridging o1l Tank, 10,000 US gallons, insulated

Bridging Oil Pump, 20 USGPM, 5 hp

oil Sampling System and Allowance

for steam tracing of crude oil

and bridging oil pipes

TOTAL EQUIPMENT COST

INSTALIATION AT $31 \%$ OF FQUIPMENT COST

TOTAL INSTALLED EQUIPMENT COST FOR AREA

\section{PRICE}

$5,467,000$

58,000

230,000

61,000

573,000

12,000

45,000

2,000

16,000

4,000

48,000 


\subsubsection{Agglomeration and Floatation:}

\section{Area 300 - Reference Flowsheet * ARC72}

\section{vesign Considerations}

The purpose of the Agglomeration and Floatation Area is to remove mineral matter and pyrite, and agglomerate the $-0.6 \mathrm{~mm} \times 0$ raw coal into $-0.2 \mathrm{~mm}$ (40 percent moisture) microagglomerates that can be further enlarged in the Agglomeration and Separation Area.

Selection and sizing of the equipment for this area has been done using the following design considerations:

- Mean resicience time required for growth of 0.2 $\mathrm{mm}$ to $0.5 \mathrm{~mm}$ flocs in high shear vessels is 4 minutes.

- Optimal solid stumy concentration is 30 percent in high shear mixers, 18 percent in floatation cell and hydroseparator.

- Total ash rejected is 69 percent of ROA coal feed ash with 48 percent rejected in the floatation cell undertiow and 15 percent rejected in the hydroseparator undertlow.

- Moisture content in floatation froth is estimated at 40 percent.

- Total pyritic sulphur rejected is 59 percent of ROM coal feed pyritic sulphur with 41 percent rejected in the floatation cell underflow and 18 percent rejected in the hydroseparator underilow.

\section{Process Dascription}

1300 tph of 29.4 percent coal slumy is recoived from the Coal and Oil Preparation Area and mixed with the bridging oil in eight parallel high shear mixers. The coal is wetted by bridging oil and formed into microagglomerates $0.2 \mathrm{~mm}$ in size. The product of the high shear mixing is diluted with 823 tph recycle water to 18 percent solids, (dry w:/w slumy basis) and is fed into four floatation cells, operating in parallel, each 150 th capacity, wet froth basis. The clean coal floated from the circuit will be approximately 556.3 tph and 40 percent moisture.

The froth is transferred to four hydroseparators operating in parallel where it is again wiluted with recycle water to 18 percent solids, whw slumy basis. The froth is washed, separated from the pyrite particles and ther, inio clean froth is transterred to a sump where it is mix $3 d$ with recycle water before it is pumped to the Agglomeration and Separation Area.

The floatation underflow, containing about 3.2 percent solids is discharged into a static thickener. A large-volume, conventional settling tank desion was selected for the thickener to accommodate projess upsets more easily. The concentrated coal refuse is removed in the vacuum disc fitter. The coal refuse from the floatation cells circuit will be approximately 55.1 th, 10 percent moisture.

The hydroseparator underflow with about 1.1 percent of solids is discharged into the second static thickener. The refuse pyrite and coal are removed in the vacuum filter and transferred together with the floatation underflow refuse to the refuse bin. The total refuse will be approximately 70.5 th and will be trucked away by coal hauling trucks.

A significant amount of process water, $823 \mathrm{tph}$, is required to dilute the product of the high shear mixers. All the required water is recovered from the fbatation circuit and is recycled back after removal of the suspended solids. 


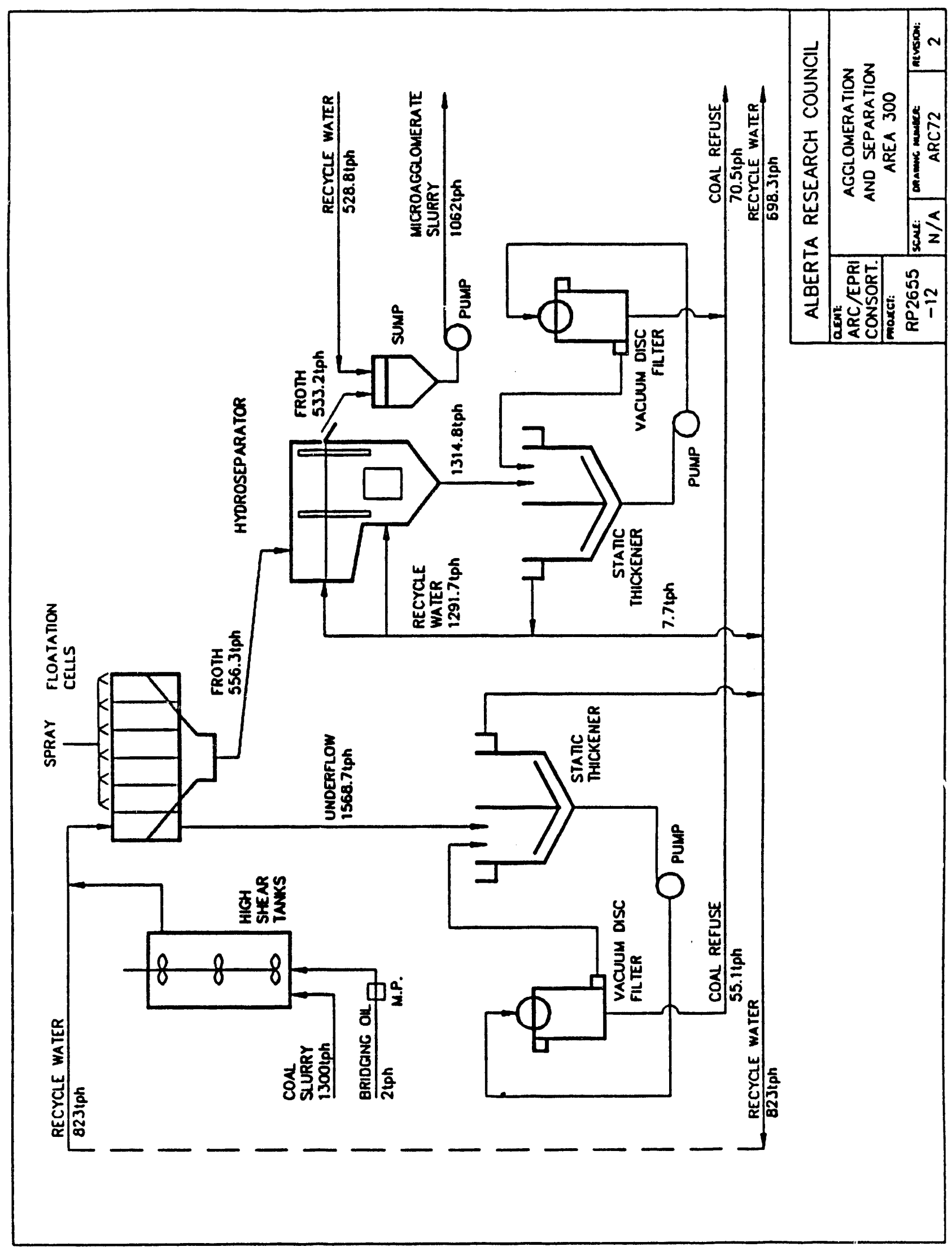




\section{PROCESS EOUIPMENT}

ESTIMATE BOMQYARY

CEIENT: ARC/EPRI CONSORTIUM

PROJECT NO.: RP2655-12
TYPE OF ESTIMATE: \pm 308 DATE OP ISSOE:

AREA DEBIGNATION: Agglomeration and Floatation: Area 300

EOUTPMENT

$\overline{-}$

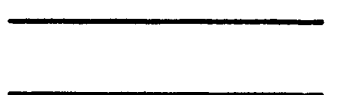

TOTAL PROCESB EQOIPMENT

INBTALLED COBT (PEIC)

ALLOWANCE YOR:

Piping

Instrumentation

Electrical

Bldg./Structural

TOTAL DIRECT COBT
INBTALLED COST

\$

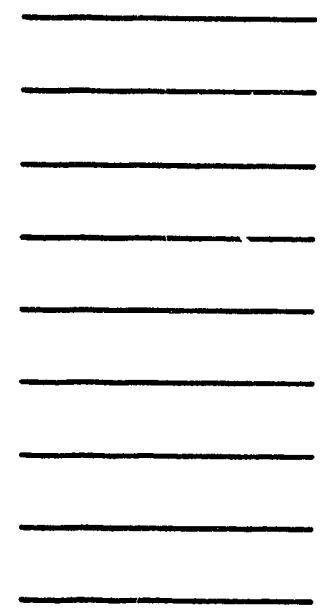

\$

$4,099,000$

$\$$

$4,913,000$

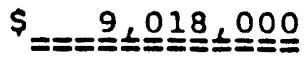


CLIENY: ARC/EPRI CONSORTIUM

PROJECT NO.: RP2655-12
Breer No.: 1 OR 2

I8BOE DATE:

AREA DESIGNATION: Agglomeration and Separation: Area 300

ITFY NO, QURYPITY

1

10

10

4

4

5

6

7

8

9

10

2

3

4

1

1

\section{DESCRIPTION}

High Shear Mixers, 2 spare, $5.5^{\prime} \phi \times 15^{\prime}$, Including agitators, $8 \times 360$ hp e 1,600 rpm

011 Metering Pumps, 2 spare, 2 USGPM, $8 \times 1$ hp

Flotation Cel18, 150 tph froth each, $4 \times 150$ hp each

Hydroseparators, 150 tph eroth each, $4 \times 180$ hp each

Static Thickner, 6900 USGPM, 3t solids loading, $73^{\circ}$ dla., $10^{\prime}$ deep $20 \mathrm{hp}$ motor

1 Vacuum Disc F1Iter, 730 USGPM, 25\% solids loading, incl vacuum pump, total motor $\mathrm{hp}=80$

Cleanup sump and Pump, 5 hp motor

Refuse Coal Belt Conveyers, $32^{\prime \prime}$ wide, $50^{\prime}$ long, total motor hp $=75$

static Thickener, 5800 USGPM, $1 \%$ solids loading, $67^{\circ}$ dia. $10^{\circ}$ deep, $10 \mathrm{hp}$ motor

Vacuum Disc Filter, 220 USGPM, 258 solids loading, incl vacuum pump, total motor hp $=25$

\section{PRTCE}

$\$ 2,121,000$

20,000

197,000

244,000

132,000

48,000

11,000

48,000

121,000

13,000 


\section{EOOIPYENT IIST}

CLIENT: ARC/EPRI CONSORTIUM

8HEET NO.: 2 OF 2

PROJECT NO.: RP2655-12

I880E DATE:

AREA DESIGNATION: Agglomeration and Sefaration: Area 300

ITEY NO, OUANTITY

DESCRIPTION

PRICE

11

5 Froth Sump Pumps, 1300 USGPM, one spare, $4 \times 30$ hp

$\$ \quad 60,000$

TOTAL EQUIPMENT COST

$\$ 3,015,000$

INSTALLATION AT $36 \%$ OF EQUIPMENT $\cos T$

$\$ 1,084,000$

TOTAL INSTALLED EQUIPMENT COST FOR AREA

$\$ 4,099,000$ $== \pm= \pm= \pm= \pm=2$ 
5.2.4. Agglomeration and Separation: Area 400-Roference Flowsheet * ARC73

\section{Design Corididurations}

The purpose of the Agglomeration and Separation Area is to enlarge the microagglomerates from $-0.2 \mathrm{~mm}$ to $0.8 \mathrm{~mm}$ to $3.0 \mathrm{~mm}$ in size, and to dewater the macroagolomerates to 10 percert moisture, whw basis.

The following desion assumptions were made in selection and sizing of the equipment:

- To achiove a narrower residence time distribution in the low shear mixers, and a more unilorm product, two mixing vessels, in series, with a combined residence time of 26 minutes are used. The second vessel also serves as a surge capacily tank belore green agglomerates are

dewatered.

- The growth process for the agglomerates require addition of light crude oil to a level of 12 percent (chy w/w coal basis).

- Low rpm centritugal extractors are to be used for dying green macroagglomerates.

\section{Process Description}

The hydroseparator product (froth) diluted to 30 percent microagalomerates slurry is pumped from the Agglomeration and Floatation Area into the low shear mixers. 38 tph of bridging oil is also added in the low shear mixers to promote growth of the floc particles into green agglomerates 0.8 to $3.0 \mathrm{~mm}$ in size. The product stury of macroagglomerates is discharged on four drain and rinse, double deck vibrating screens, where it is drained, rinsed and dewatered. The green agglomerates from the D\&F screens will be approximately 463 tht and 25 percent molsture.

The wet acglomerates are transferred to eight centritugal extractors operated in parallel where the procuct is turther dewatered to 10 percent moisture. The extractors are oscillating, conical-screen type and operated at low rpm.

All process water from the DaR screens' underflow and the centrituges is recycled to the Coal and Oil Preparation Area. 


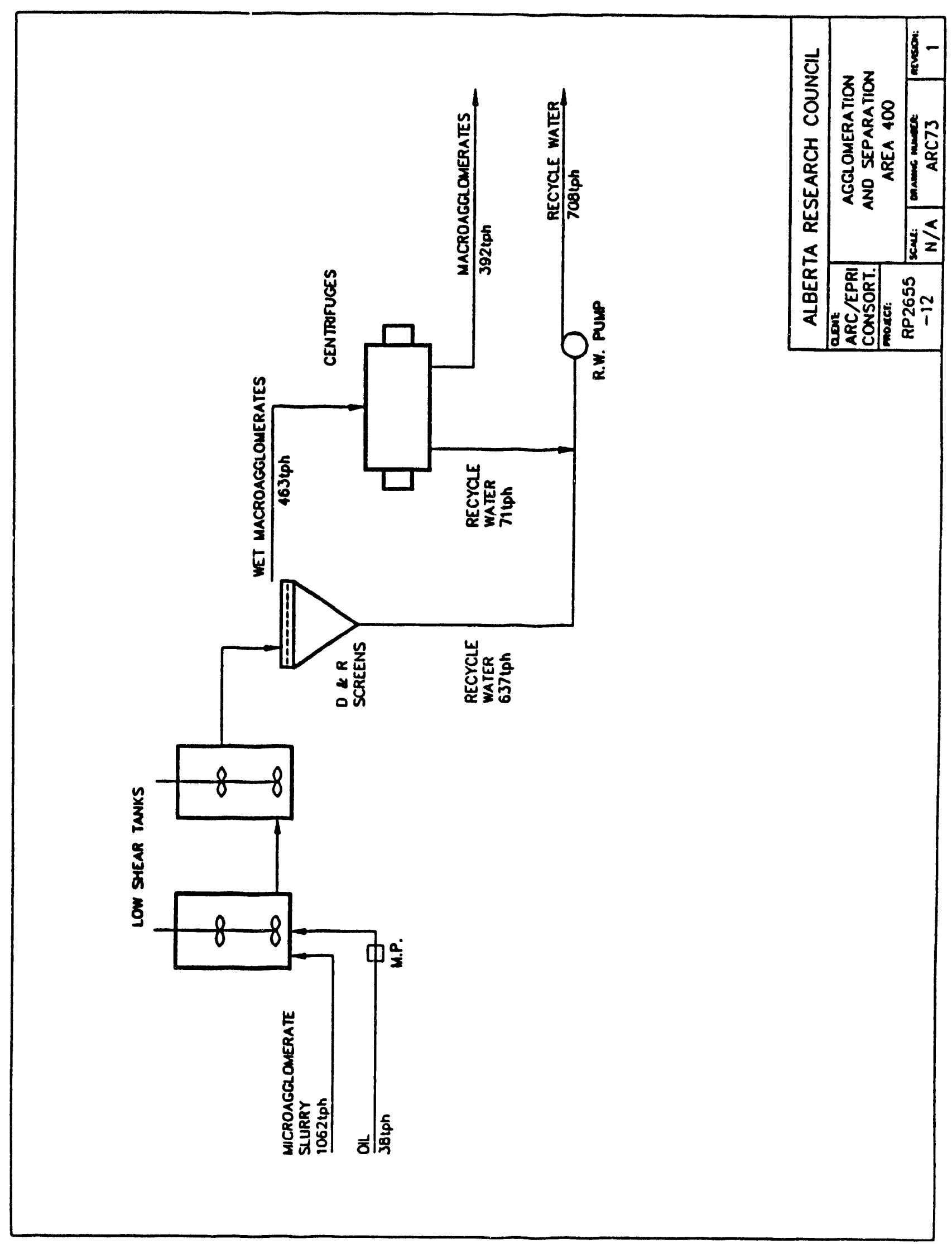




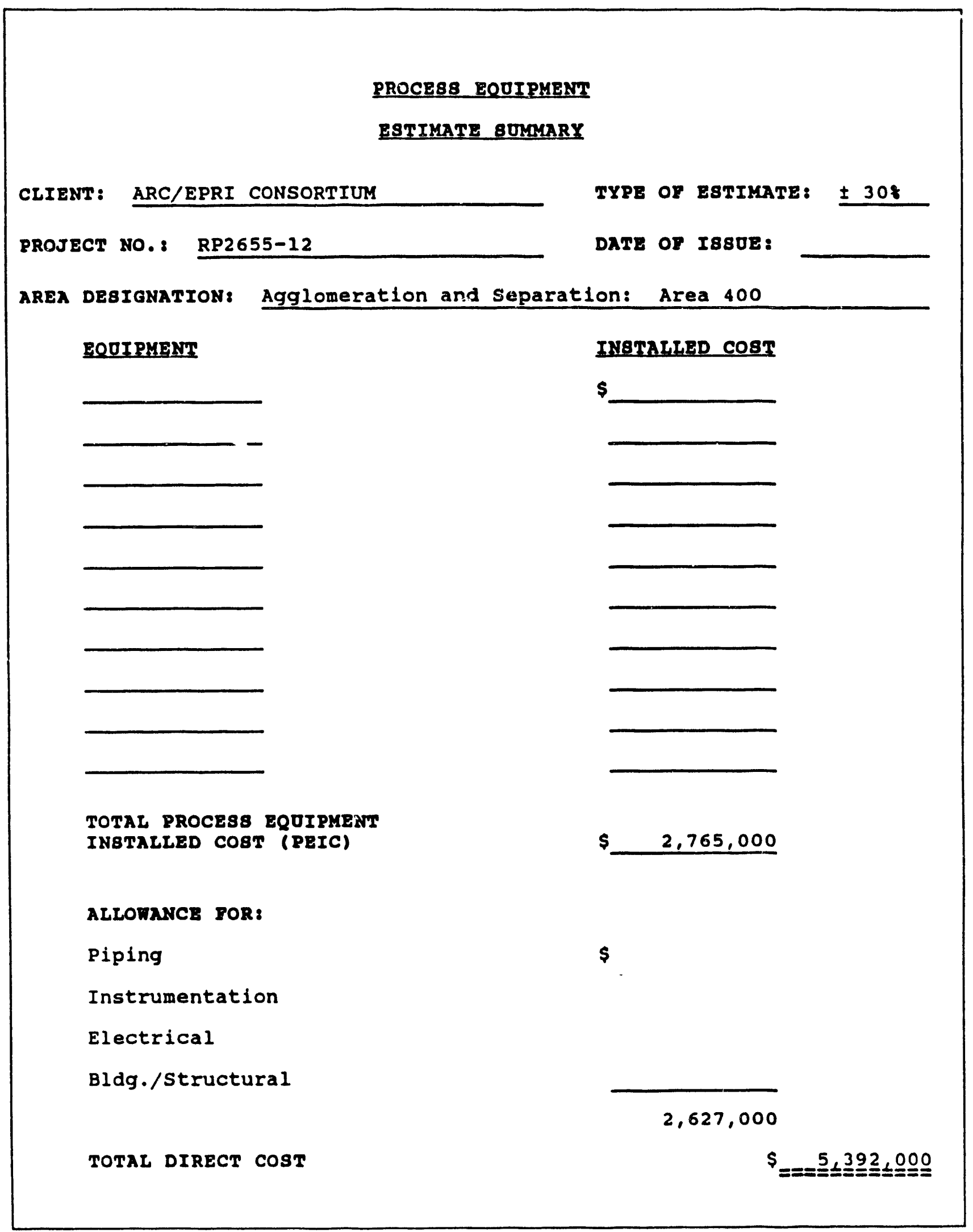


EOOIPMENT LIST

CIIENT: ARC/EPRI CONSORTIUM

PROJECT NO.: RP2655-12

AREA DEsIGMATION: Agglomeration and Separation: Area 400
ITEY NOe OONITIY

1

2

3

4

5
8

4

4

10

2
DESCRIPTION

Low Shear Mixers, $12^{\circ} \times 22^{\circ}$, incl. agitators, $8 \times 120 \mathrm{hp}$ $600 \mathrm{rpm}$

Bridging oll Metering Pumps

Drain and Rinse Screens,

$12^{\circ} \times 17^{\circ}, 150 \mathrm{tph}$ each, $0.8 \mathrm{~mm}$ apertures double deck, discharge chutes

Centrifugal Extractors, $60 \mathrm{tph}$ solids each, two spare, $80 \mathrm{hp}$ each

Recycle Water Pumps, 1800 USGPM each, $2 \times 40 \mathrm{hp}$

TOTAL EQUIPMENT COST

INSTALLATION AT $36 \%$ OF EQUIPMENT COST

TOTAL INSTALLED EQUIPMENT COST FOR AREA
BHEET NO.: 1 or 2

I8808 DATE:

PRICP

$\$ 743,000$

$\$ \quad 29,000$

$\$ 257,000$

$\$ \quad 975,000$

$\$ \quad 31,000$

$\$ 2,035,000$

$\$ \quad 730,000$

$\$ 2,765,000$

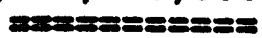




\subsubsection{Water Treatment: Area 500}

- Reference Flowsheet \# ARC71

\section{Design Conslderations}

The basic design and cost information for treating the make-up water for the Aglofloat process was based on water treatment package plants.

\section{Process Description}

For the plant water needs, well or surface water will be treated and stored in the recycle water pond. The well or surface water will be treated to process water quality standards. In addition, a small amount of water will be treated for drinking water and for sanitary purposes. 


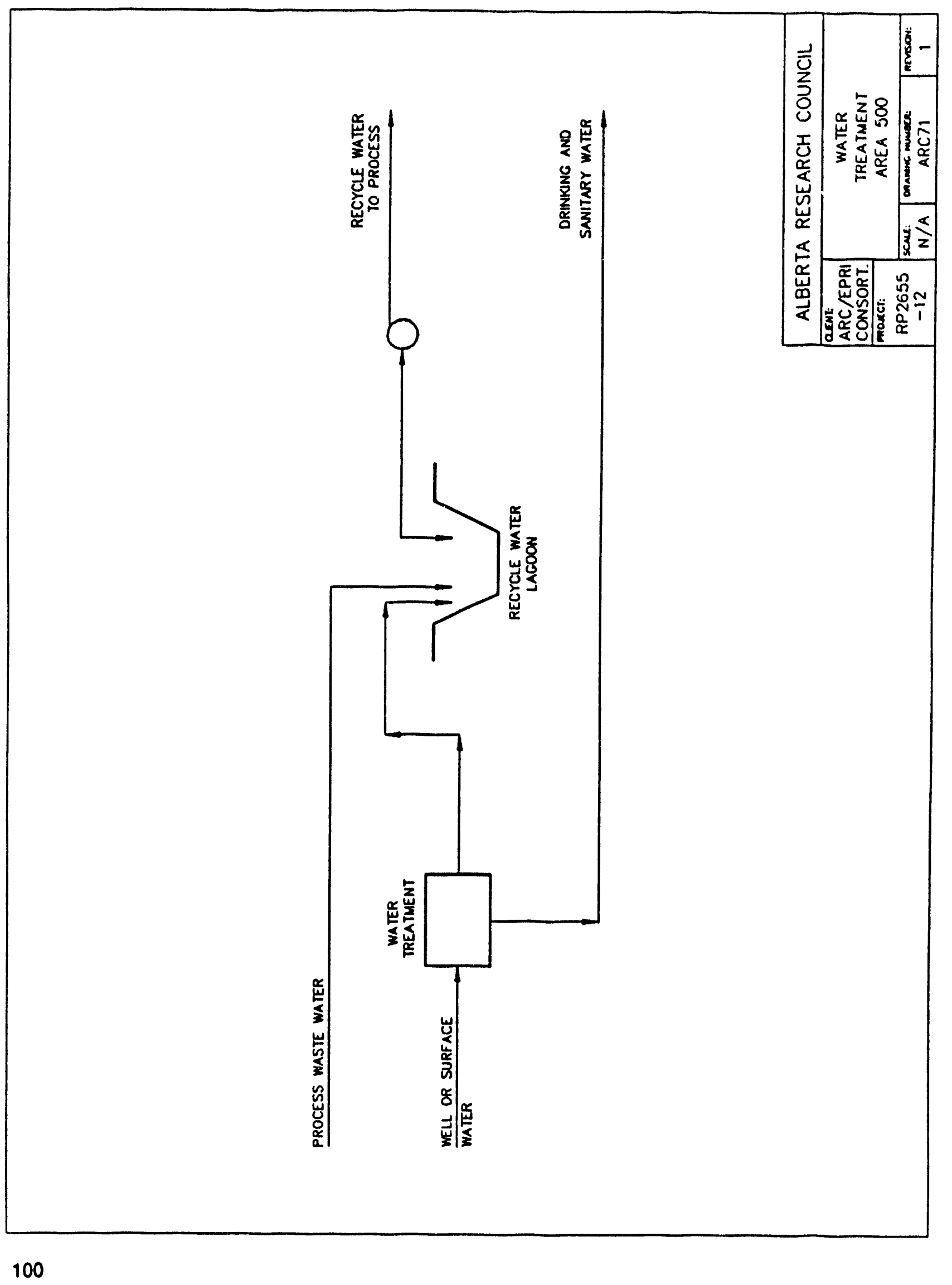




\section{PROCESR BOOT PYENT}

\section{EstThate s0YMARY}

CLIENT: ARC/EPRI CONSORTIUM

TYPE OF ESTIMETE: \pm 308

PR/AJECT NO.: RP2655-12

DATE or I8808:

AREA DE8IGNATION: Water Treatment: Area 500

\section{EOOT PYENET}

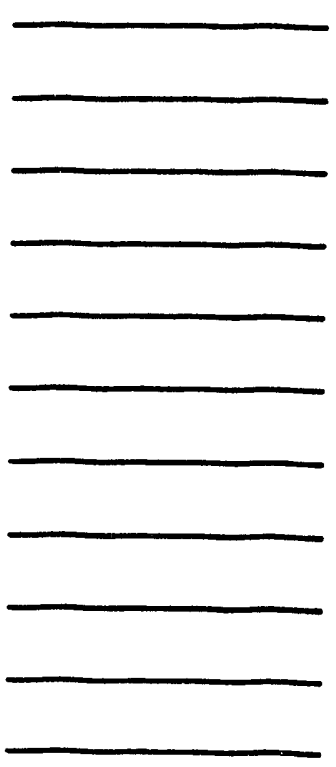

TOTAL PROCES8 EQTIPMENT INBTALLED CO8T (PEIC)

ALLOWANCE POR:

piping

Instrumentation

Electrical

Bldg./Structural

TOTAL DIRECT COBT

\section{INBTALLED COST}

$\$$
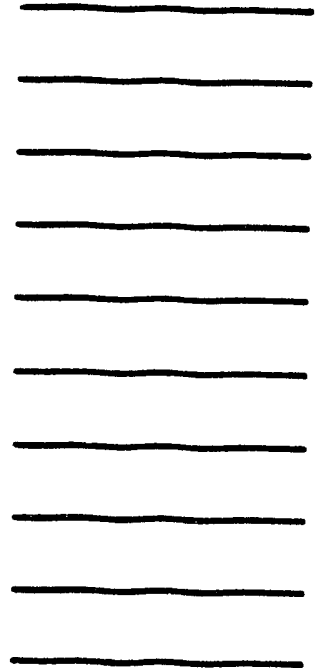

$\$$

$\infty$

$\$$

$=-1+150,000$ 
EOOI PMENT LI8T

CLIENT: ARC/EPRI CONSORTIUM

PROJECT NO.: RP2655-12

BHEET MO.: 1 OF 1

I880E DATE:

AREA DEBIGNATION: Water Treatment - Area 500

ITEY NO, QUANTITY

DERCRIPTION

PRTCE

Total Direct cost from data for packaged plants, water quantity and quality:

Make-up Water Requirements $32.5 \mathrm{tph}$

Energy Requirements: $\quad 100 \mathrm{hp}$

TOTAL DIRECT COST FOR AREA 500

$\$ 1,150,000$ $\mathrm{n=}=\mathrm{x}=\mathrm{=}==$ 


\subsubsection{Product Loedout: Area 600}

- Reference Flowsheet \# ARC70

\section{Design Considarations}

The design of the Product Loadout Area for agglomerates and coal refuse provides two days production storage for agglomerates and three days production storage for coal refuse. The badout facility for rail cars has been included in the design.

\section{Process Deecription}

The dry agglomerates product will be transferred from the Agolomeration and Separation Area via bell conveyors. A single 10,000-ton live capacity ground stockpile will be maintained. The product will be withdrawn from the stockpile by vibrating feeders and transierred to a 500-ton badout bin for bading into railcars via a shuttle conveyor.
The weighing system is a simple design using the tare weight of the railcar and track scales. A track mobile will be used to move the cars during bading. Prior to shipping, the surface of the product will be sprayed with a latex solution to prevent dust losses enroute and to conform to environmental industry standards.

The coal refuse is transferred from the Agglomeration and Floatation Area at the rate of 70.5 tph to 500 ton capacily refuse badout bin. The refuse will be loadod on coal delivery trucks and hauled back to a display area. In case of emergency, coal retuse can be directed to an outside, 3-day emergency refuse storage pile. The refuse will be withdrawn from the pile with a front-end bader and conveyor system. The refuse pile area will be constructed using a proper ground lining and drainage trenches for run-off waters. 


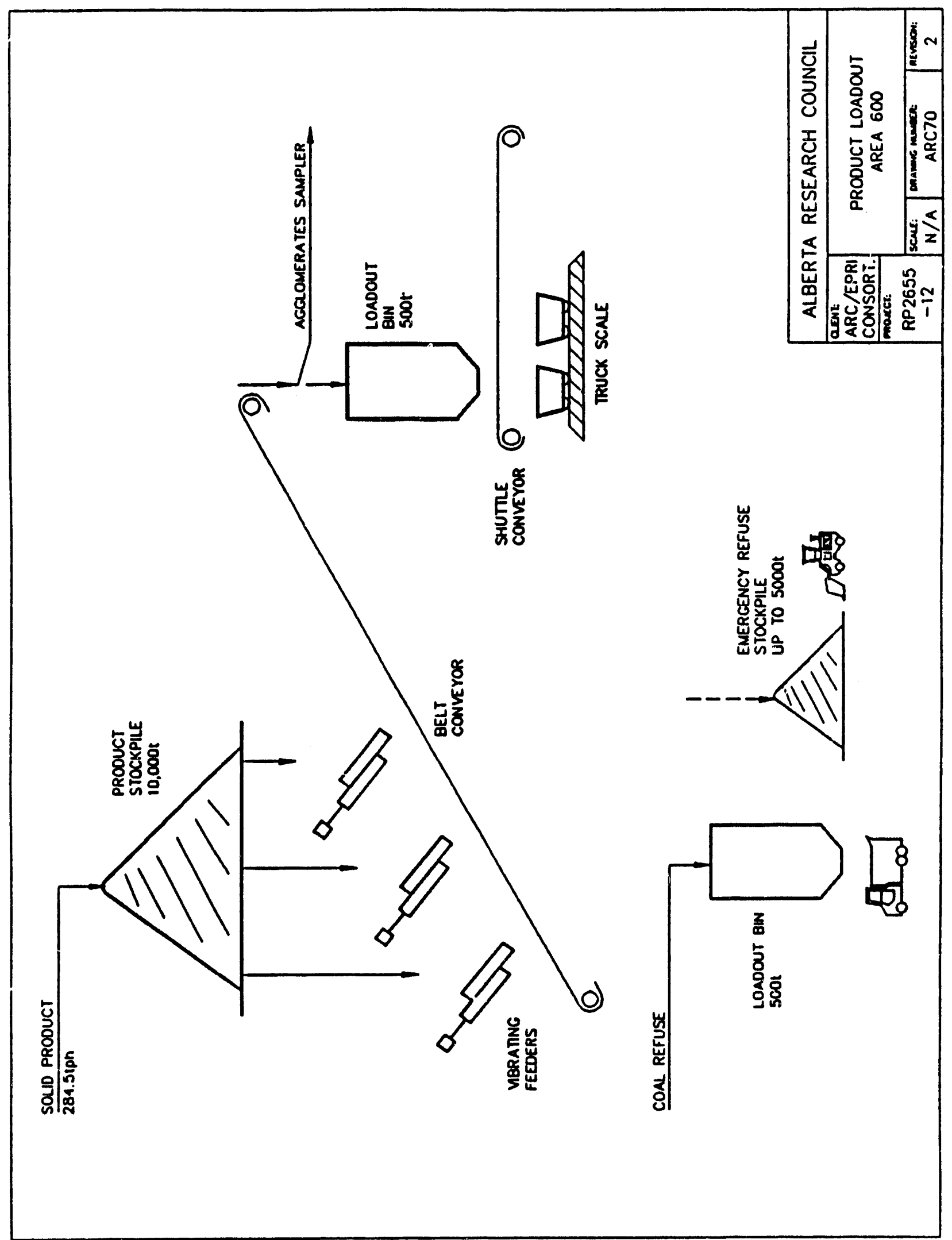




\section{ESTIMATE 8UMERY}

CLIENT: $\frac{\text { ARC/EPRI CONSORTIUM }}{\text { TYPE OP ESTIMATE: }}$ DA307
PROJECT NO.: RP2655-12 OP I880E:
AREA DESIGNATION: Product Loadout: Area 600

EOUI PYENT

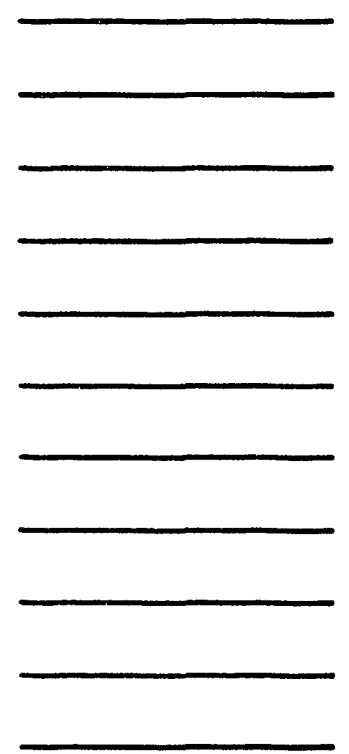

TOTAL PROCES8 EQOIPMENT

INBTALLED COBT (PEIC)

ALLOWANCE FOR:

Piping

Insitrumentation

Electrical

Bldg./Structural

TOTAL DIRECT COST

\section{INBTALLED COST}

\$

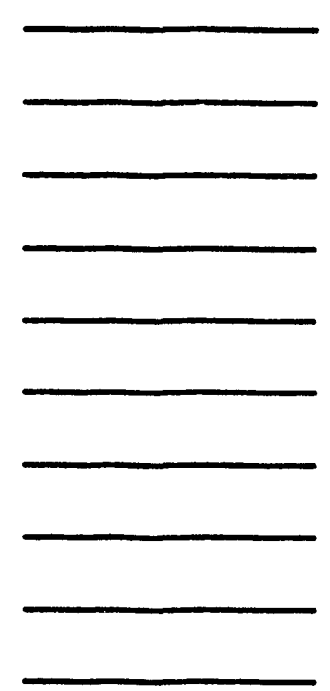

\$

$6,971,000$

\$

839,000

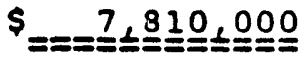


CLIENT: ARC/EPRI CONSORTIUM

PROJECF NO.: RP2655-12

8HEET NO.: _ OE

I880E DATE:

AREA DESIGNATION: Product Loadout: Area 600

ITFY NO, QONAFTTY

DERCRIPTION

PRICE

1

Product stockpile storage Area, Live Capacity $10,000 \mathrm{t}$, Includés site preparation, reciaim tunnel and dust collection system.

2

6

3

4

5

6

7

8

9

2

Reclaim Vibrating Feeders, 150 tph capacity each, total motor hp $=60$, discharge chutes

500 t Capacity Agglomerates Loadout Bins

90,000

Allowance for Ra11 Car Loadout system

188,000

Belt Conveyors: Allowance for 750

ft of $30^{\prime \prime}$ belts, total hp $=200$

172,000

Latex or Calcium Hydroxide spray system

29,000

Coal Refuse Bin, 500 t capacity

102,000

Coal Refuse/storage Area, Live Caracity, $5000 \mathrm{t}$, includes site preparation, reciaim hopper and conveyor belts, total motor $h p=80$

1 Front End Loader

267,000

TOTAL EQUIPMENT COST

$\$ \quad 6,873,000$

INSTALLATION AT 1 OF EQUIPMENT COST

$\$$

$2,314,000$

TOTA1. INSTALLED EQUIPMENT COST FOR AREA

\$ $6,971,000$

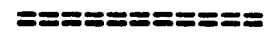




\subsection{Design Basis}

\subsubsection{Design Basis: Summary of Process Electrical Requirements}

Table A5.6. Summary of process electrical requirements.

\begin{tabular}{|c|c|c|c|}
\hline Area & Description & $\begin{array}{c}\text { Connceted } \\
\text { H.p. }\end{array}$ & $\begin{array}{c}\text { Oporating } \\
K w\end{array}$ \\
\hline$\overline{100}$ & $\begin{array}{l}\text { Coal bolveny, Storago } \\
\text { and Crushing }\end{array}$ & 905 & 681 \\
\hline 200 & Coal and Oil Proparation & 10,330 & 7,768 \\
\hline 300 & $\begin{array}{l}\text { Agglomeration and } \\
\text { Fbatation }\end{array}$ & 4,548 & 3,420 \\
\hline 400 & $\begin{array}{l}\text { Agglomeration and } \\
\text { Separation }\end{array}$ & 1,700 & 1,278 \\
\hline 500 & Wate Treatment & 100 & 75 \\
\hline \multirow[t]{2}{*}{600} & Product Loadout & 340 & 256 \\
\hline & Total & 17,923 & 13,478 \\
\hline
\end{tabular}

\subsubsection{Design Basis: Operating Cost Estimates}

Tablo A5.7. Aglolloat Process: Plant Oporations.

\begin{tabular}{|c|c|c|c|}
\hline $\begin{array}{l}\text { arbes and Wages } \\
\text { ay Shift }\end{array}$ & Numbore & & Total \\
\hline $\begin{array}{l}\text { ant Supenintendont } \\
\text { oneral Plant Foreman } \\
\text { ocoses Engineor } \\
\text { ocoses Techniciar Analyst } \\
\text { chnical Clork } \\
\text { hipping Foreman }\end{array}$ & $\begin{array}{r}1 \\
1 \\
1 \\
+\quad 2 \\
1 \\
1 \\
4\end{array}$ & $\begin{array}{l}\$ 50,000 \\
45,000 \\
45,000 \\
37,000 \\
25,000 \\
42,000 \\
25,000\end{array}$ & $\begin{array}{r}\$ 50,000 \\
45,000 \\
45,000 \\
74,000 \\
25,000 \\
42,000 \\
100,000 \\
\$ 381,000\end{array}$ \\
\hline
\end{tabular}

Subtotal

$\$ 514,000$

\section{Shin Workere}

Coal Dolivery and Reclaim Attendant

Coal and Oil Preparation

Agglomeration and Floatation Agglomeration and Separation Contral Control Oporator

Shitt Foreman

Payroll Burden @ 35\%

Subtotal

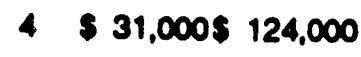

4
4
4

$31,000 \quad 124,000$

$31,000 \quad 124,000$

$31,000 \quad 124,000$

$31,000 \quad 124,000$

$42,000 \quad 168,000$

$\$ 788,000$

$\$ 276,000$

$\$ 1,064,000$

Total: Plant Operating Labour

$\$ 1,578,000$

Operating Suppliee

Chemicalo

Water Traetmem

Floculant $50 \mathrm{kght}$ of methylieobutyl cartinol $\quad 560,000$ $\times 7,000 \mathrm{hre} \times \$ 1.60 \mathrm{~kg}$

Latox Spray

Fuel

185,000

$4.5 \times 10^{3}$ MMBtuy natural gas $\times \$ 2.90 \mathrm{MMBtu} \quad 131,000$

Electricity

$94.5 \times 10^{-} \mathrm{kWh} \times \$ 0.065 \mathrm{kWh}$

Water

$60.2 \times 10^{\circ} \mathrm{gal} \times \$ 0.6 / 1000 \mathrm{gal}$

ROM Coal

$400 \mathrm{ph} \times 7000 \mathrm{hrs} \times \$ 27.00 \mathrm{~h}$

Cruds On

39.6 tph $\times 7,000$ hrs $\times \$ 102.6 h$

Dioeed

0.4 thh $\times 7,000$ hrs $\times \$ 178.4 h$
36,000

$75,600,000$

211, 441,000

500,000 
Table A5.8. Maintenance cost estimate: Aglofloat.

\begin{tabular}{|c|c|c|c|c|c|}
\hline Aroa & Deseription & $\begin{array}{l}\text { Cotal are } \\
\text { cort } \\
000^{\prime}\end{array}$ & Annual & $\begin{array}{l}\text { Annual } \\
\text { lobour }\end{array}$ & $\begin{array}{c}\text { Cost, } \\
\text { OoO's } \\
\text { Materlals }\end{array}$ \\
\hline 100 & $\begin{array}{l}\text { Coal Dolivery, } \\
\text { Storage and } \\
\text { Crushing }\end{array}$ & 5,267 & 3 & 63 & 95 \\
\hline 200 & $\begin{array}{l}\text { Coal and Oil } \\
\text { Preparation }\end{array}$ & 12,742 & 4 & 204 & 306 \\
\hline 300 & $\begin{array}{l}\text { Agglomeration } \\
\text { and Floatation }\end{array}$ & 9,018 & 6 & 216 & 325 \\
\hline 400 & $\begin{array}{l}\text { Agglomeration } \\
\text { and Soparation }\end{array}$ & 5,392 & 6 & 129 & 194 \\
\hline 500 & Water Treatment & 1,150 & 3 & 14 & 21 \\
\hline 600 & Product Loadout & 7,810 & 3 & 94 & 141 \\
\hline \multicolumn{4}{|c|}{ Total Maimtenance Cost } & 720 & 1,081 \\
\hline
\end{tabular}

\subsection{Design Data}

Table A5.9. Analysis of design ROM coal, coal rofuse and dried clean coal product.

\begin{tabular}{|c|c|c|c|}
\hline & $\begin{array}{l}\text { Feod } \\
\text { Coal }\end{array}$ & $\begin{array}{c}\text { Rofuse } \\
\text { Coal }\end{array}$ & $\begin{array}{l}\text { Clean } \\
\text { Product }\end{array}$ \\
\hline $\begin{array}{l}\text { Proximate, percent } \\
\text { Noisture } \\
\text { Ash } \\
\text { Volatile } \\
\text { Fixed Carbon }\end{array}$ & $\begin{array}{r}2.0 \\
17.0 \\
36.5 \\
44.5\end{array}$ & $\begin{array}{l}10.3 \\
66.9 \\
10.1 \\
12.7\end{array}$ & $\begin{array}{r}2.2 \\
6.2 \\
40.4 \\
50.6\end{array}$ \\
\hline $\begin{array}{l}\text { Uttimate } \\
\text { Moisture } \\
\text { Ash } \\
\text { Carbon } \\
\text { Hydrogen } \\
\text { Nitrogen } \\
\text { Sulphur, organic } \\
\text { Sulphur, pyrite } \\
\text { Oxygen (difi) }\end{array}$ & $\begin{array}{r}2.0 \\
17.0 \\
66.4 \\
4.3 \\
1.1 \\
1.2 \\
2.4 \\
5.6\end{array}$ & $\begin{array}{r}10.3 \\
66.9 \\
19.3 \\
1.2 \\
0.3 \\
0.6 \\
8.0\end{array}$ & $\begin{array}{r}2.2 \\
6.2 \\
76.9 \\
4.9 \\
1.3 \\
1.3 \\
1.2 \\
6.0\end{array}$ \\
\hline $\begin{array}{r}\text { Heating Value, Bturb } \\
\text { GJ/ }\end{array}$ & $\begin{array}{r}11,900 \\
27.4\end{array}$ & $\begin{array}{r}3,350 \\
7.7\end{array}$ & $\begin{array}{r}13,300 \\
30.7\end{array}$ \\
\hline
\end{tabular}



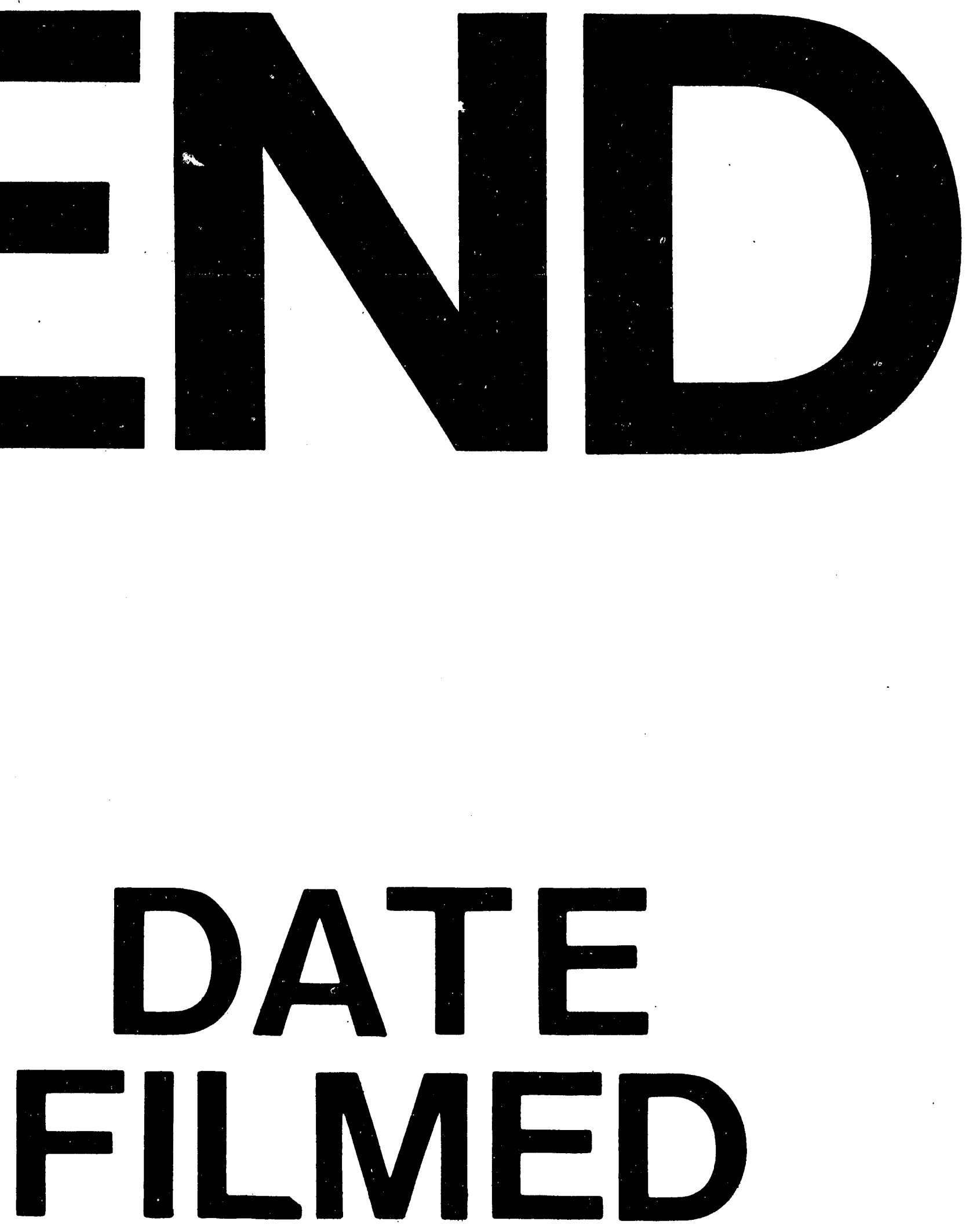

1

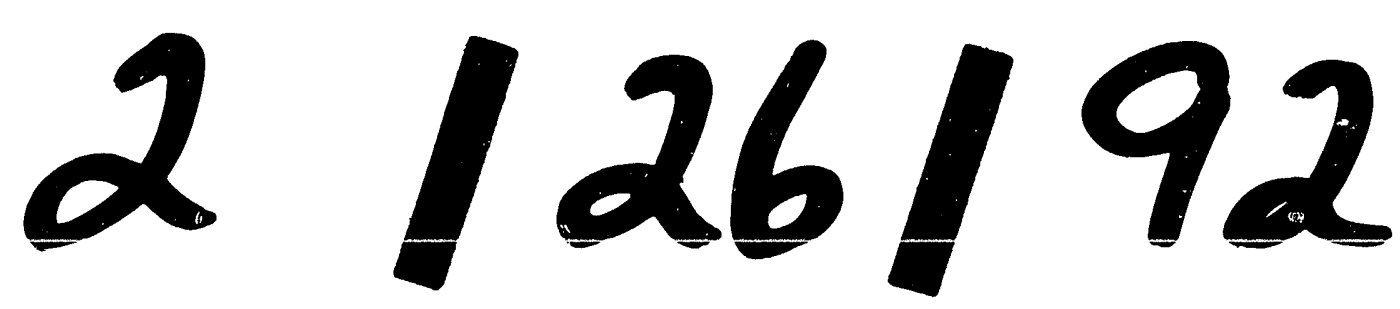


